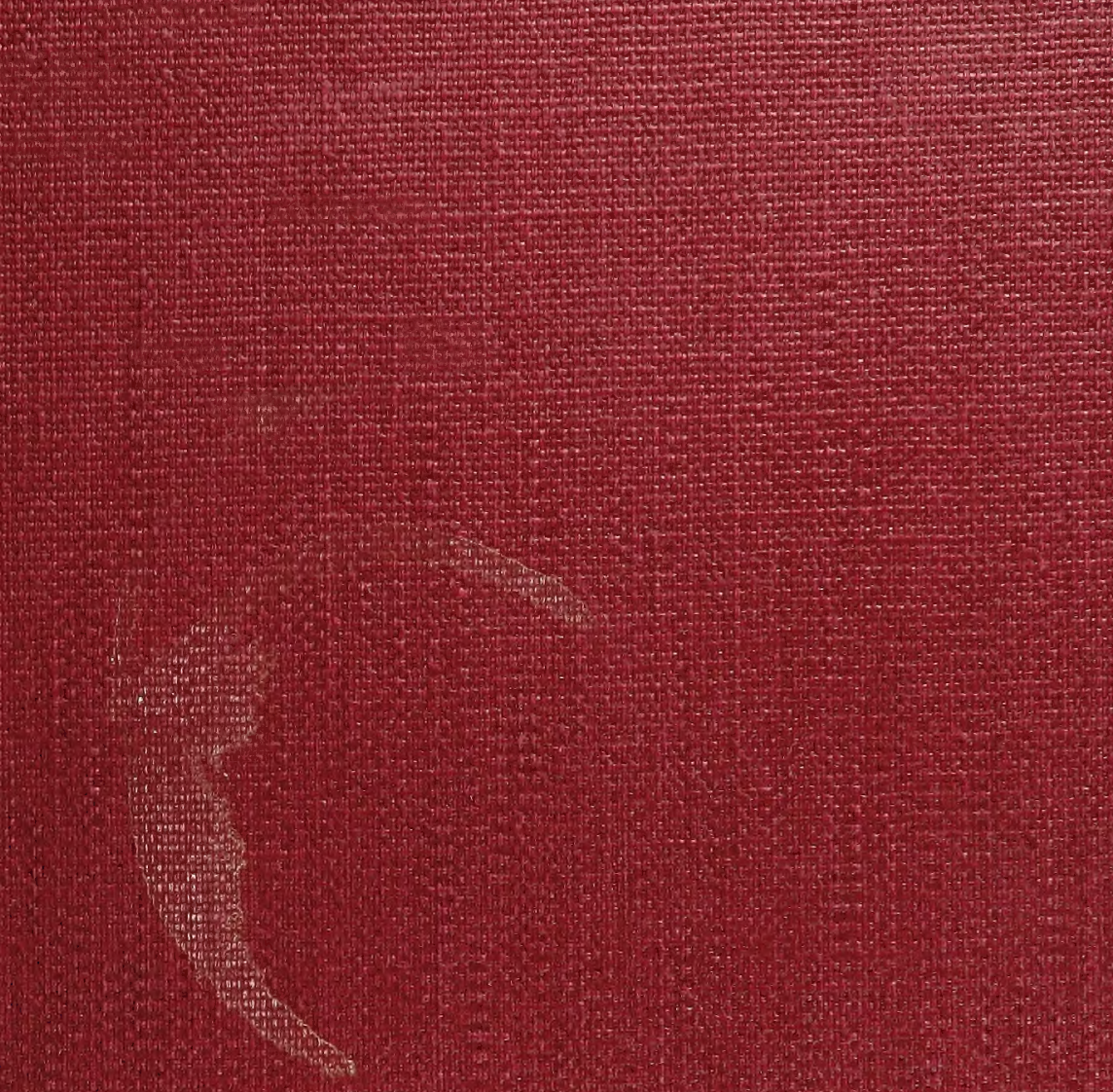




\section{DT \\ 35 \\ A 37}

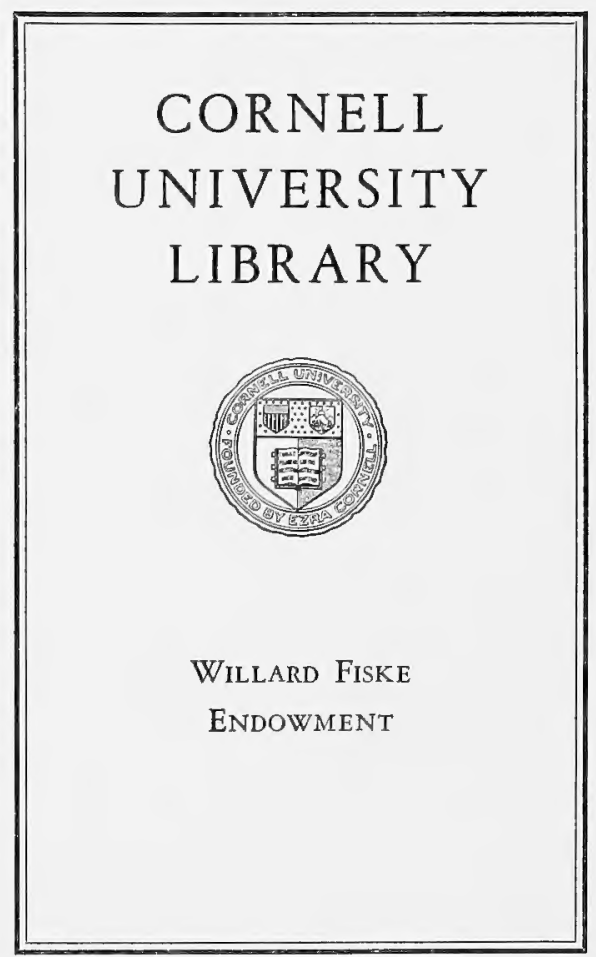




\section{DATE DUE}

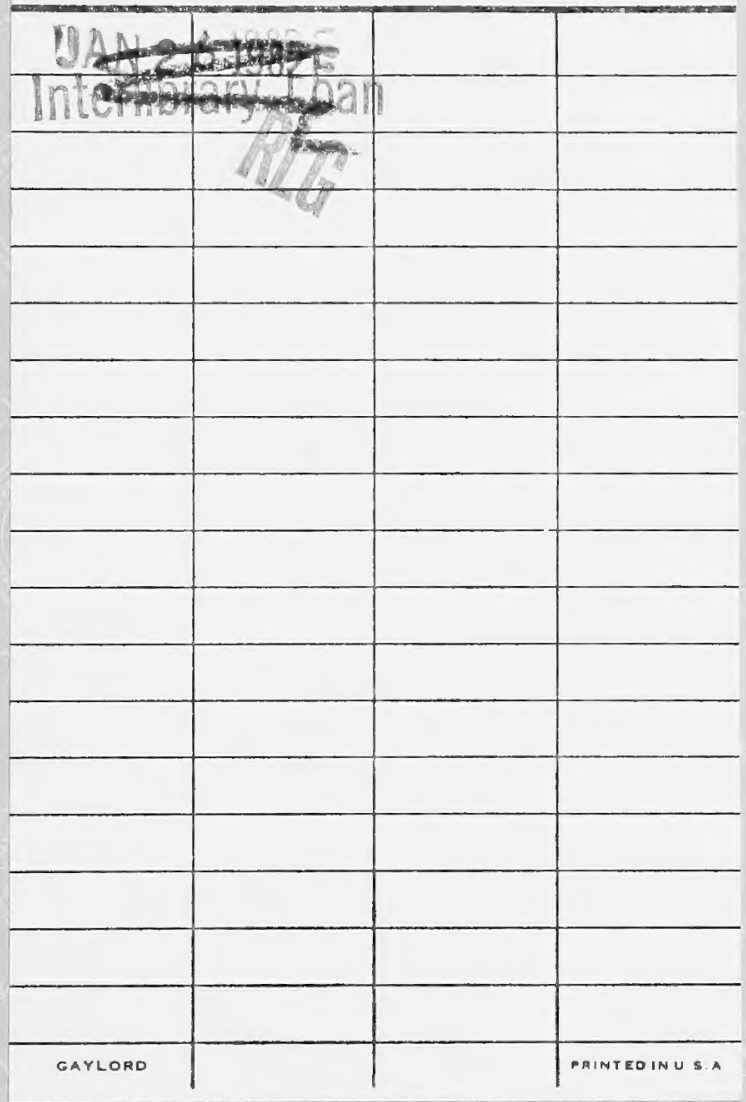




\section{Cornell University Library}

The original of this book is in the Cornell University Library.

There are no known copyright restrictions in the United States on the use of the text.

http://www.archive.org/details/cu31924088413269 



\section{FROM THE NIGER TO THE NILE}






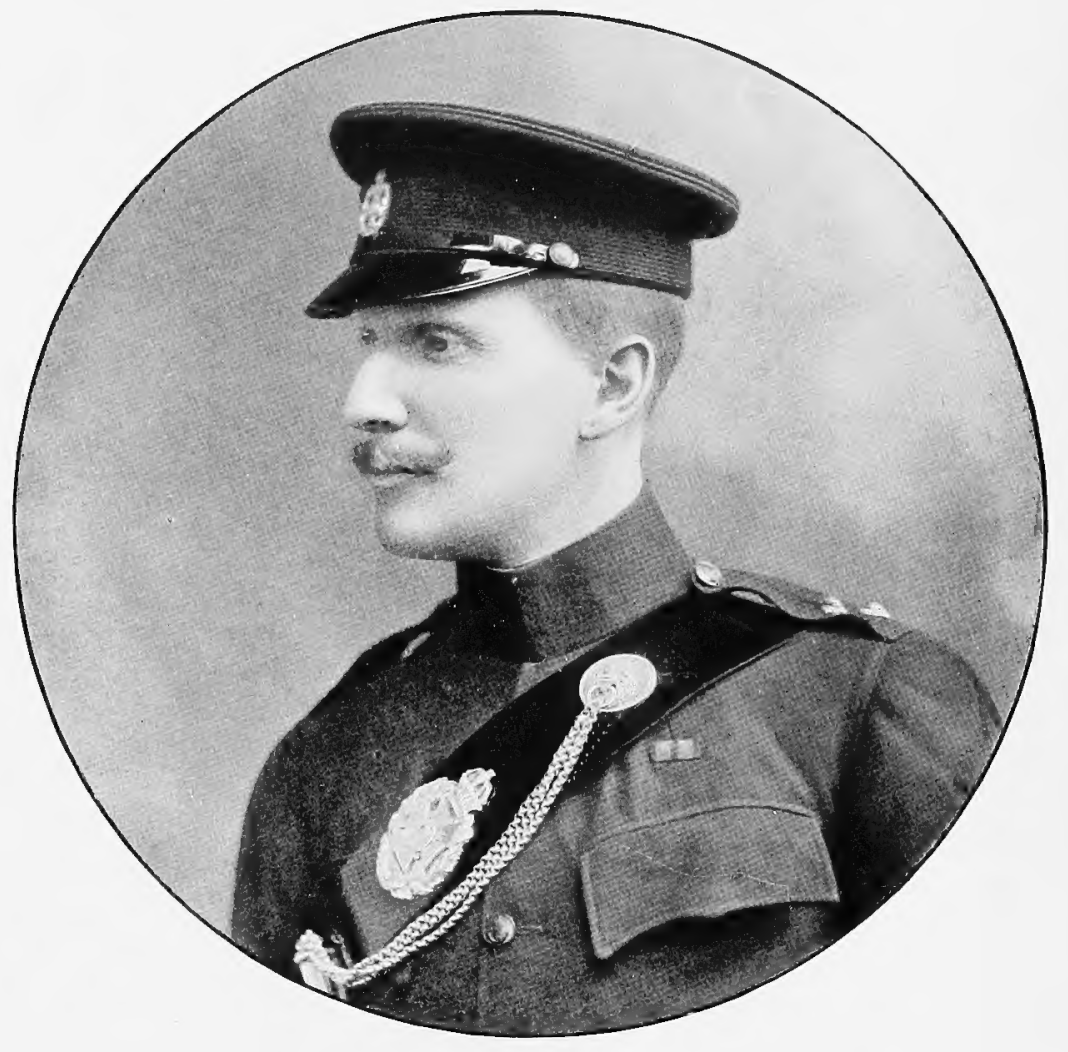

LIEUT. BOYD ALEXANDER

RIFLE BRIQADE 




\title{
FROM THE NIGER TO
}

\section{THE NILE}

BY

\section{I,IFU'IENAN'I' BOYD ALEXANIDER \\ RIFIAE BRIGADE}

IN TWO VOLUMES

VOT,UME I

WITH ILLUSTRATIONS AND MAPS

\author{
LONDON \\ EDWARD AR NOLD \\ 扫ubligher to the Endia offere \\ 1907
}


1

i

;

$\mathrm{Hr} /$

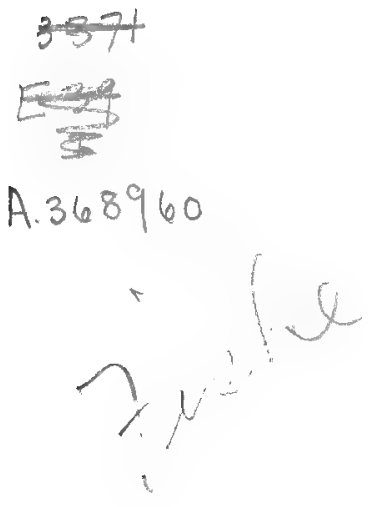




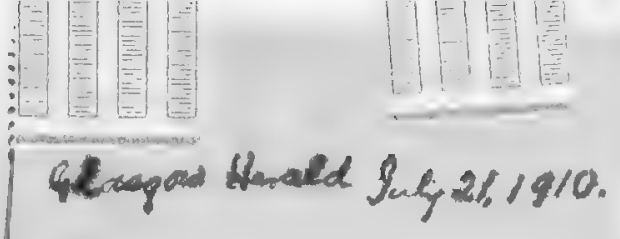

\section{THE MURDER OF A BRITISH OFFICER.}

\section{LIEUT, BOYD ALEXANDER'S TRAGIC END.}

Reuter's Agency has received the first details of the murder of Lieutenant Boyd Alexander, who was recently killed in Wadai while on an important expedition across Africa. The intclligence comes from, Lieutenant Cbilders Thompson, commanding at the British post of Maifoni, in the Lake Chad region, with whom the late explorer stayed for a month. The com- 1 dT …

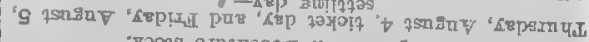

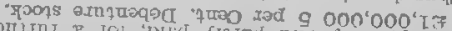

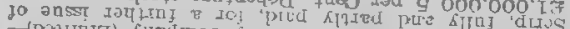
5 -

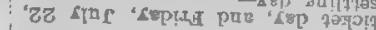

' -: "zis

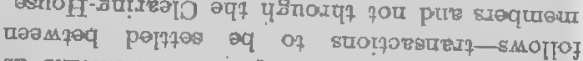

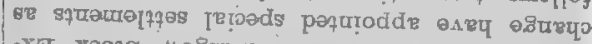

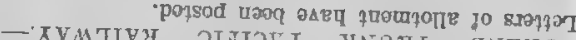

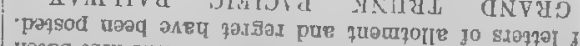

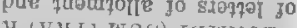

10 .

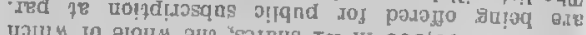

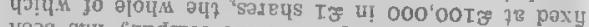

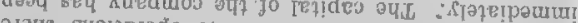

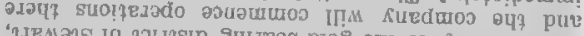
"7.

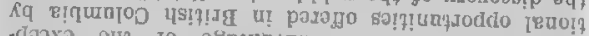

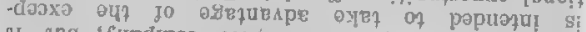

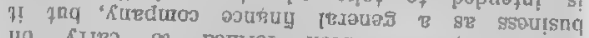

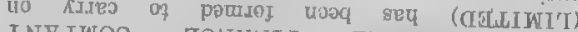

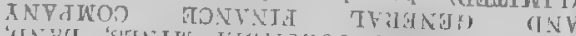

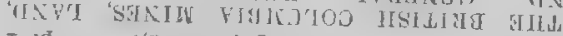
I d ' Jo esnot sulquind poys!q

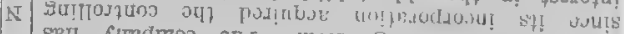

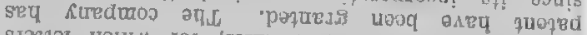

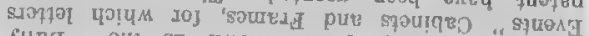
Rl!eC ,"

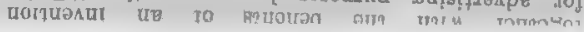


1

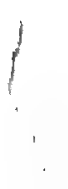

17

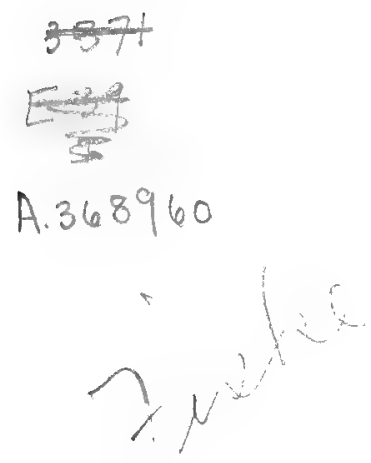


TO

MY LOST COMPANIONS 


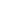




\section{PREFACE}

IN the early days of the Expedition, before the shadow of death had fallen across our path, and when there were three eager and brave companions to share the work with me, I always had the idea in my mind that when we were safe home again we would go over the results of our work, each gathering the harvest of his special line for embodiment in a scientific record. At the same time I had hopes that a general history of our journey would some day be written by my brother, Claud, in whose literary capabilities for the work I had the greatest confidence. But, alas! those hopes were never to be realised, and only a few pages of notes and minute observations in a tiny, neat handwriting, and a $\mathrm{f} \in \mathrm{w}$ pretty and quaint descriptions in letters written home remain to show what that book might have been. His share of the work endures in the splendid map, which his co-worker, Mr. Talbot, brought home and finished with untiring labours. With my brother's death I abandoned all hope that the story of the Expedition would ever be written, and I intended only to collect the scientific records, publishing the notes on each department in separate proceedings.

But a friend pointed out to me that my contribution to science would not be complete unless a faithful history of our travels were written-of the difficulties overcome and the resources used in the overcoming; the good and the bad in 
human nature, white and black, that under such conditions we were bound to have come across; and of the effect upon the imagination of nature in regions never before visited: if only all these things could be faithfully depicted they would be instructive, and, therefore, of scientific value.

I saw his point, and that must be my excuse for this book. But not my only excuse; for at the same time I believed that, if only I could succeed, I should be placing a monument in their country to two brave men, who lie in the earth too far away for many to read the records over their graves.

But had it not been for the help of my brother, Herbert, I fear I should have found it impossible to present in other than quite inadequate literary shape the rough material with which I returned.

I am anxious to acknowledge the kindness of Mrs. Gosling in placing at my disposal her son's diary and photographs which have been of very great help to me ; and I could only wish for the sake of my book that I had been able to use the diary still more, for there are many interesting notes to which I have not the key, as we were often separated for weeks at a time, working at great distances from one another.

My thanks are also due to Mr. Talbot for the account of the Survey Expedition which he made with my brother, and for a number of the photographs which illustrate this book.

I have endeavoured as far as possible to convey the impression of a continuous forward movement, as being one less tiring for my readers to follow. But this was most diffcult to do with that part of the story told in the first volume, , which sometimes has to deal with three columns working in 
different directions hundreds of miles apart. So my apologies are due to my readers, if I am sometimes obliged to ask them to retrace their steps with mine while I return to pick up the threads of the story.

To my critics I would say that I was trained to the profession of the sword, so would ask them to deal gently with my attempts to handle the proverbially mightier and, therefore, more difficult weapon.

B. A.

The Ark, Studland,

October 1907. 


\title{
CON'TENTS OF VOLUME I
}

\author{
CHAPTER I \\ INTRODUCTION
}

Object, constitution, and equipment of expedition, with details regarding outfit, trade goods, and medicines, \&c. - The qualifications of explorers for tbeir different lines of enterprise-Difficulties to get leave of absence-Arrival of expedition at mouth of Niger . . . . . . . . . . Pp. 1-18

\section{CHAPTER II}

\section{OUR JoURNEY UP THE NIGER AND BeNUE}

The putting together of the steel boats-Journey up the Benue, with descriptions of the life on the river-Arrival at Ibi-Getting the survey instruments into working order-Hunting in the neighbourbood-The prowess of the Munchi in killing game-The crocodile pool_Slave traffic-Tsetse fly-Difficulties of survey -Success at last . . . . . . . . . . . . Pp. 19-47

\section{CHAPTER III}

\section{A LION HUNT}

Beacon fires at Serikin Kudu-Rumours of lions-On the track of the man-eatersWe find the lion-The lion finds us-Death of the lion-The autopsy-An attack of black-water fever-Josés ride for aid-My recovery-Carried into Ibi-Start of the boats for the river Gongola; and of the survey party for Northern Nigeria

\section{CHAPTER IV}

\section{With the Survey Party to the Murchison Range}

Details of the work-Description of the country and inbabitants met with-Sickness attacks both members of the party-In hospital at Wasé-The famous Wasé Rock

\section{CHAPTER V}

\section{The Survey Continded to Ashaka}

Trouble with the Montoil pagans - Famine-The wonderfulKerri-Kerri country-The release of two slave girls 


\title{
CHAPTER VI
}

\section{The Survey Continued to Malfon I}

A forest of baboons-'Talbot's fight with the Marragi-His heroism . I'p. 122-143

\section{CHAPTER VII}

\author{
UP THe Goygola River to Ashaka
}

Gosling shoots a giraffe-Description of the Benue and inhabitants-FamineTrouble with boats' crew-Passage of boats up the Gongola-Gosling's over]and journey to Ashaka

\section{CHAPTER VIII}

The JoURNey OF THE BoATS TO Yo

Description of Yo river-The famous Ghambaru ruins-First sight of Tubus-The Kachella of Yo-Boat reaches Lake Chad-A marriage ceremony-Gosling's journey to Maifoni . . . . . . . . . Pp. 163-181

\section{CHAPTER IX}

\section{MY JOURNEY FROM LOKO TO DORRORO}

My return to Lokoja-Convalescence-Leave Loko-Remarks on the native interpreter-Descriptions of scenery and birds-the Fulani and Hausa races, their origins-Arrival at Dorroro-Uses of the phonograph-The singing of the red thrush . . . . . . . . . . . Pp. 182-202

\section{CHAPTER X \\ Mx Journey Continued to Ashaka}

Bridge-building-Charon's ferry-The Petti pagans-Curious ornaments-The fierce Kagorro tribe-A view of fertile Nigeria-Arrival at Bauchi-Meeting with the Emir-The good king's woes, and remedy-The bad king's crime, and remedy-Hausa wrestling . . . . . . . . Pp. 203-221

\section{CHAPTER XI}

\section{My Journey Continued from Ashaka to MaIfoni}

The scene of the Burmi fight-Arrival at Gaidam-The Tubu family, their releaseBad news at Yo-Leave for Maifoni-First sight of Lake Chad-Tweedledum and Tweedledee-The Buduma at Kaddai-Graver news at Bre-Post-haste for Maifoni

Pp. 222-240

\section{CHAPTER XII}

\section{MaIFonI}

Description of the place-The home for freed slaves-My brother's illness and death. 


\section{CHAPTER XIII}

\section{From MaIfoni to Kukawa}

Maidugari market-Survey-work along the road-The land of wells-"Maifoni " makes his bow-Children of Noah-Arrival at Kukawa-The completion of the . $\operatorname{map}$

Pp. 263-280

\section{CHAPTER XIV}

THE SHeHU OF KUKAWA

A string of his prisoners-The story of Kiari-The Shehu's palace-My visit to him - His treasure-house-Photographer by Royal appointment-The sacrifice

\section{CHAPTER XV}

\section{From KUKAWA TO KADDAI}

Our trade-Our camp by the market-The Harmattan wind-Arrival at Kowa-The Kanembus-'Their methods of hunting-The Maiobush-Water-finding-Evening by the lake-side-The camp fire-Dumbornu's practical joke-Arrival in camp

\section{CHAPTER XVI}

\section{OUr First Voyage on Lake Chad}

The native soldier-Gosling's collection of fish-Description of the Lake- "The beautiful things which are not"; the sober reality-We try to find a passage to the south-Hardships-The mysterious Budumas, their canoes and fishing-The first night on the Lake-Mosquitoes and flies-Sight- of land-Buduma cattle. huts-A diet of rats-Jonah goes overboard-Failure to find a passage-A fishing-fleet-Return to the Yo mouth . . . . . . Pp. 316-334

\section{CHAPTER $\cdot$ XVIL}

\section{Christmas in Camp at Kaddai}

Mapping the western shore-line-The Dorcas gazelle-The Lake makes a night attack-The Expedition reunites-Making soldiers - The bathing parade-Other members of the Expedition-The Kanembu shepherd-boy-Preparations for Christmas : presents, the feast and concert-'Talbot leares for England-Gosling's hunting trip-He bags an elephant-" Rabeh," the bush kitten-Collecting oxen-The rascally King of Gashagar; his starving victim in the stocks-I catch a thief-A reprimand-At Maifoni again-I am fined $£ 5$. . Pp. 335-358 


\section{LIST OF ILLUSTRA'TIONS-VOL. I.}

Lieutenant Boyd Alexander (Rifle Brigade)

PAGH

\section{The Boat Sections}

Frontispiece

Native Canoes of the Expedition on the River Benue Facing

The Source of the Niger .

.17

The Expedition on the River Benue .

José skinning Birds

Crossing the River on a Gourd .

Native "Dug-out"

Camp of the Expedition on a Sandbank of the Benue

Gosling's little Cannibal Friend

Meeting the Anglo-German Boundary Commission

Umuru with a Dwarf in Ibi market

Snake Charmer at Ibi

In Ibi market

Native Method of Cupping

King of Lafan Gisseri

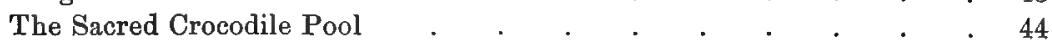

Montoil Cannibal Chief

The Penalty for Thieving.

The Murchison Range from Ibi

Facin

Wife of the King of Lafan Gisseri

The Lion

River Simanki. .

"Then out flew the Little Union Jacks"

Natives near Yelua, grinding Corn

Doorway of a Montoil Hut

A Stockaded Village of the Ankwe

Yergum Pagans .

Burnt Gurkaua Village-Huts and Granaries

Yergum Pagans .

Yergum Pagans .

Montoil Cannibals

The Wasé Rock .

Montoil Pagans running away from the Survey Party 
A Woman of the Seaua Pagans near Bauchi

Claud Alexander crossing the River Gital .

A Kerri-Kerri town

Fitcing 108

Gamari

Ascending a Kerri-Kerri plateau

View of Gamari from the Peak .

A Barburr town

Barburr Girls at Kwaia

The Kerri-Kerri country

A Baobab tree.

The Giraffe Hunt (some of the "field") . Gosling's Giraffe

A Fulani $O x$

Bush Fulani

Fulani architecture

A Hausa merchant 
Talbot with Damessa returning to England

Captain Claud Alexander (Scots Guards) .

The house in which Claud Alexander died

The Grave of Captain Claud Alexander

A Shua Woman .

A string of the Shehu's prisoners

Kanuri Women

The Shehu's Palace

Some of the Shehu's army.

Garoba, Shehu of Bornu

At the Moment of the Sacrifice .

Transport of the Expedition in Bornu Cloth stall in Kukawa market

\section{A Kanuri Girl}

The Lowan of Kowa's "dash"

A Buduma canoe laden with dried fish 



\section{CHAPTER I}

\section{N T RODUCTION}

JUST as before the actual accomplishment of our journey when, impatient to be moving upon the way, we had to tarry many tedious months while the scheme and its arrangements were being thought out, weighed, and put in order; so it is with the narrative which attempts to set forth the history of this Expedition. It will be necessary, I fear, to keep the reader waiting for the plain, progressive story of our travels, while an account is given of the somewhat tedious details of constitution and equipment.

The scheme was germinating in my mind for many years. The idea did not come as a sudden impulse to be acted upon as one might take a ticket to the farthest point upon a line. It was rather the result of a succession of thoughts leading naturally one from the other till a chain was linked with such perfect sequence that it stimulated the imagination to put it to the test.

Every explorer looks upon the map of that part of the world which particularly calls him, and endeavours to find a spot that still affords opportunity for the special powers he may possess for finding out the secrets that it hides. The mountaineer will set his heart upon the ascent of some unconquered height. Thus Ruwenzori, the highest peak of the African continent, had attracted the attention of many a 
renowned Alpinist, finally to lower its crest beneath the foot of the Duke of the Abruzzi. Other travellers have distinguished themselves in that form of exploration which depends for its success upon a great knowledge of peoples and languages, men like Barth and Burton conquering the desert by their powers of getting into touch with the people of the caravans. The great humanitarian Livingstone followed the map as it is expressed by the distribution of the tribes; while geographers, such as Stanley, have left the featureless desert on one side and taken their ways by hills that make beautiful undulating shadings, and rivers that embroider with blue veinings, and lakes that shine like jewels-upon the map.

In Africa Lake Chad was the last gem that remained uncut and wanting a proper setting. There it lay in the desert waiting. For the last decade the attention of many travellers had been turned to it, for the little that was known of it was so mysterious that it appealed very much to the imagination. The fact that it was a desert lake, with the reason of its existence unexplained, stimulated speculations; also, it was known that there was an interesting people inhabiting the islands, about whose existence and habits very little had been found out. All these facts attracted me, and, there was the distribution of the fauna to establish, with the hope that a locality, showing geographical peculiarities, might also reveal marked differences in its fauna. This last idea naturally took a strong hold of me, for I will now confess that my ruling passion is ornithology, and all my exploration might be described as taking the course of the birds. Although the French had for years shown great 
activity on their side in exploring her mysteries, and in spite of the patient work of Barth and Overweg, Lake Chad had not yet yielded up her secret; her fish and her birds were still unknown, her shores and islands undetermined, and her dwellers remained as illusive as herself. Thus it was that I came under her spell, and Chad became the pendant that I aimed at hanging upon the links of our other enterprises.

About the autumn of 1898 three French expeditions started from west and north and south to converge on Lake Chad. Gentil, fighting against enormous difficulties, came from the west by the Congo and Ubanghi rivers and succeeded in reaching the Lake. Foureau came down from Algiers through the Sahara, and was not heard of in the desert for nearly a year. About the same time a third expedition set out from Senegal under Voulet and Chanoine, the story of whose progress of pillage and rape and murder forms the darkest page in the history of Africa. For some unhappy reason (perhaps their incapability to withstand the temptations of supreme power, and perhaps the trying African climate had inflamed their worst passions), they had not gone far from the restraint of authority before they gave way to the most terrible excesses of cruelty and appetite. And when rumours of their abuses reached a French post, and a superior officer was sent out to arrest them, they ordered their soldiers to shoot him down as he approached, and then stripped the uniform off his body. Thus, by the murder of a white man having crossed the Rubicon of crime, and knowing that they could never return to their countrymen and live, they became desperate and went mad in a fearful orgy of crimes, leaving a bloody trail of horrors and death behind 
them as they went through the country, till their own native soldiers were glutted with the debauch of murder and lust and turned their rifles upon the wretched officers. The survivors from the wreck of the expedition under Joalland and Meynier eventually reached Lake Chad and joined with the forces of Gentil and Foureau.

Thus Chad has for years been the goal that has called forth the efforts of rival men and rival nations in the race of exploration, and round the subject of this water desert a history could be written of the ambitions of men, of their strength and their weakness, of heroism, of horror, of failure and of success.

Now, as Chad was made the chief object of our enterprise it determined the nature of the Expedition, for it was necessary to take boats for the exploration of the Lake. And this, in turn, decided the route, for of course we should have to use the riverways as much as possible to get the boats on to the Lake. Then in my mind having got them there it occurred that a way out might be found across the continent eastwards, for an explorer never cares to come back upon his tracks. Studying the waterways with this object in view revealed a wonderful river system right away to the Nile, and my imagination was at once fired with the idea of crossing Africa by boat. At the same time the possibility of linking the Eastern fauna with that of the West, and of proving its affinity engaged my attention and claimed a great part in my speculations.

In talking over my scheme with my brother, I found him very keen to join in the venture, and this, of course, gave me great encouragement, as he had many qualifications 
to make his co-operation a very great help to me. His service throughout the length of the South African War had made him a practical leader and he had also a great aptitude for survey work and was an experienced photographer. But not the least part of his usefulness was his talent for arrangement and his tact in business dealings which greatly lightened the labours of the initial preparations. The idea now developed of adding the mapping of the country from the Benue to Lake Chad to our programme, and my brother at once spent his leave in working for and gaining the diploma of the Royal Geographical Society, so as to equip himself fully for the projected work.

The whole scheme appeared beautifully complete when my brother officer, Captain G. B. Gosling, catching fire at the account of our plans, eagerly joined forces as a hunter and field-naturalist; and henceforward the Expedition was to be known as the Alexander-Gosling Expedition. The possessor of an iron constitution, a thorough and distinguished sportsman, and having seen active service in India and South Africa, no better man than Gosling could have been found for the work, and the circumstance that he was an R.B., like myself, made the partnership all the more satisfactory.

As our plans were now increasing their dimensions, it was necessary to find a helper for my brother's department and we were very lucky in securing the services of Mr. P. A. Talbot, whose recent experience of similar work on the Liberian Boundary Commission rendered him admirably fitted for the post.

Then last to be mentioned, though not the least important 
auxiliary to our forces, is my collector José Lopes, my righthand man for usefulness; for, not only was his experience gathered on my previous expeditions very valuable, but he also combined in his person the offices of collector and interpreter, for he had a good knowledge of Hausa, gained when he was with me on the Gold Coast. This last accomplishment of José's was extremely useful in more ways than one; for, by its means he was able to keep his finger (so to speak) upon the pulses of the boys and let me know quietly when their tempers were out of order, so that I could forestall outbreaks of discontent by tact and firmness, steadying the foundations before the structure began to rock. He was able, also, to get further into the confidence of the rulers and chiefs we came across, and so we obtained a great deal more information of interest than would otherwise have been possible.

José Lopes has been my faithful servant for ten years. I found him as a little boy, working on his father's tradingboat that plied between the Cape Verde Islands. Since then he has been through five expeditions with me and has.seen active service in Ashanti. $\mathrm{He}$ is an expert skinner and good shot and thoroughly understands the working of transport. For this last expedition, I foresaw that his old calling of the sea would come in extremely useful for the management of our boats. Before we started José went through a course of instruction at South Kensington to complete his knowledge in the skinning of the larger beasts, such as giraffe and antelope.

Having arranged our scheme of work and brought together our party, the hardest obstacle had yet to be overcome, and that was to obtain leave from our regiments and to bring down 
the blessing of the Colonial Office and Intelligence Department on our plans, and a good many months were spent in "working the oracle" and clearing away the red-tape entanglements. But time was not wasted while waiting,

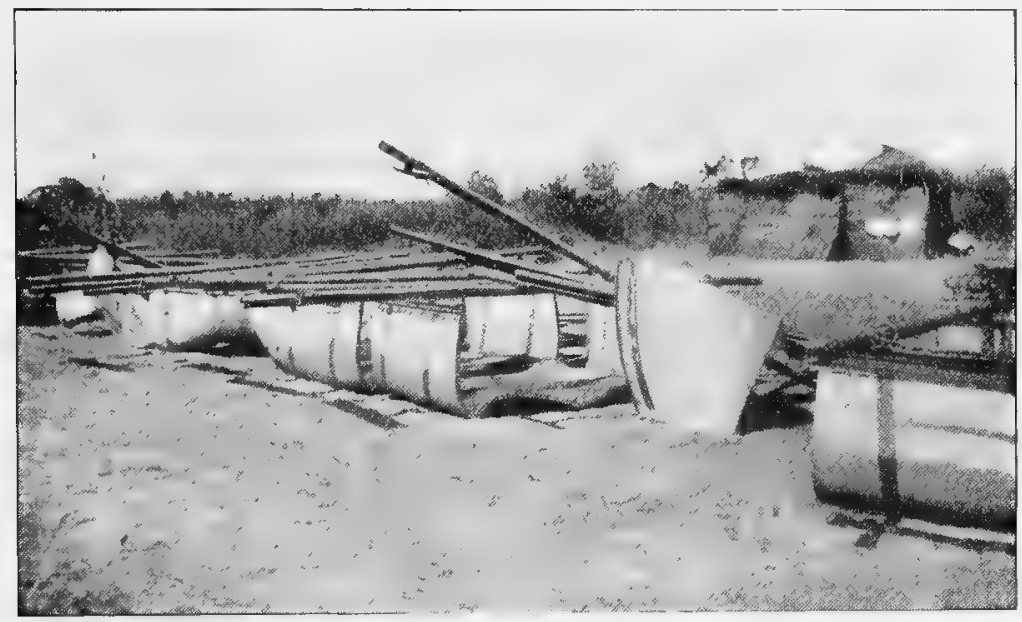

THE BOAT SECTIONS

for we had sufficient faith in our luck to put the building of our boats in hand before we received the official sanction.

The boats were made by Forrest Brothers in their yards at Wivenhoe, Essex. They were constructed on the Hodgett principle; that is to say, they were double-keeled, with slightly convex bottoms. They were made of beaten steel; $26 \mathrm{ft}$. long and $6 \mathrm{ft}$. in the beam; with a depth of $4 \frac{1}{2} \mathrm{ft}$. ; drawing $1 \frac{1}{2} \mathrm{ft}$. to every $2 \frac{1}{2}$ tons. They carried lug sails, and were constructed in six sections, each boat taking twenty-four men to carry by means of poles run through rings attached to the gunwales. They were painted white, one picked out with a black and green band for the Rifle Brigade, and the other with a blue and red for the Scots Guards. As the former 
carried Gosling and myself, the naturalists of the party, she was christened The Ibis, and the latter was named Cassiopeia as she carried my brother and Talbot, who were the geographers. I had derived the idea for their construction from the boats used by Major Gibbons on his expedition up the Zambesi ; but I dispensed with engines, which werc so apt to get out of order, and relied, instead, on native methods of propulsion by paddles or poles. Moreover, I substituted beaten steel for aluminium, which would never have stood the rough work among the rapids, and our boats were made rather broader in the beam, as they had to balance the weight of twelve polers each. The total cost for the two without fittings was $£ 380$. It would be hard to exaggerate the importance of these boats to the Expedition, for in many places they did the work of bullock transport and carriers, which were impossible to obtain in some of the countrics that we passed through.

It must be remembered that in so large an expedition; embracing so many enterprises, it was necessary at times to support a great number of followers, sometimes 200, who had to be paid and fed, and for this purpose a great amount of trade goods were carried. These included cutlery ranging from sword blades to needles, stuffs, from 14,000 yards of cloth to reels of cotton; medicines from iodoform to hairoil ; as well as mirrors, beads and bracelets and many other things. Shopping in those days was an extensive and arduous operation which, I fear, our masculine natures did not altogether appreciate. Often since then I have thought that I threw away an opportunity of scattering happiness by not making it over to a lady to do for us. For shopping is 
said to consume the feminine mind as a passion. Imagine, then, the revelry that could be got out of so large and varied a list of things as I have but only cursorily described! I recall the circumstances of a day's shopping at Evans and Company. I was wanting some unbleached calico, or baft. I made my choice and the girl behind the counter asked me how many yards I would require. When I replied I would take 5000, she, with wonderful presence of mind, said: "I think the manager had better attend to you-I will send for him." As it happened, the manager had fore-knowledge of my case, and we soon got to business, which ended the incident in a different way to that which I am sure was looked for by the girl. Doubtless, she waited expecting momentarily to see the manager's apparent tactics of temporary pacification terminate with the arrival of some form of gentle restraint.

In deciding on the various kinds of trade-goods to take out with us, I acted upon experience I had gathered in the markets of the Gold Coast Hinterland, where the caravans passed through to the coast. The more civilised people of Nigeria and Bornu, such as the Hausas, Fulani, and Kanuri, were the best buyers of the large quantities of baft, or unbleached calico, and sheeting, for they found these took their favourite blue dye very well, which is the prevalent colour of their clothes. And the wealthier aniong them were greatly attracted by our French flowered cambrics, red and blue, and we did quite a good trade among the mallams, or priests, with a fine white turban cloth. Another very favourite stuff was red flannel, which the big men bought to cover their saddles with. Scents and hair-oil were also very much sought after by the people of Bornu, a fact which. 
I think, revealed a trace of their Eastern origin. They did not care at all for beads, preferring the Maria Theresa dollar, which they beat and make into silver ornaments.

Our cheaper and gaudier materials, such as coloured handlkerchiefs and striped stuffs, went better among the pagan tribes. Beads were not much in request till we came among the Budumas of Lake Chad, and they would only look at the white ones. Then later on, in the Shari-Ubanghi region, little red and white ones were practically the only currency among the natives, except salt. It is strange and inexplicable to note how the demand for a certain article varies among the different tribes and is even affected by the colour. Red or white beads, or cloth, or whatever it might be, that from one tribe could buy fowls and eggs and large quantities of food, perhaps among a neighbouring people would hardly buy anything at all. But the things which were in demand equally throughout all peoples we came across were looking-glasses, a fact which spoke plainly of the one weakness that is universal with mankind.

Later on, as our trade goods began to run low, we treasured up all our old tins and bottles, which we discovered had quite a wonderful trade value, and then we realised that our "boys" * had for a long time been making enormous profits out of them. And it was some little time before we could break them of the habit of causing them to disappear, and a law had to be passed making it criminal for them to pick up old bottles or tins, which had almost been thrown at their heads a short time before !

It must be borne in mind that a matter needing consider-

* A term applied to all native servants of the white man. It has even been borrowed by the French, who have coined the word "boyesse" for women. 


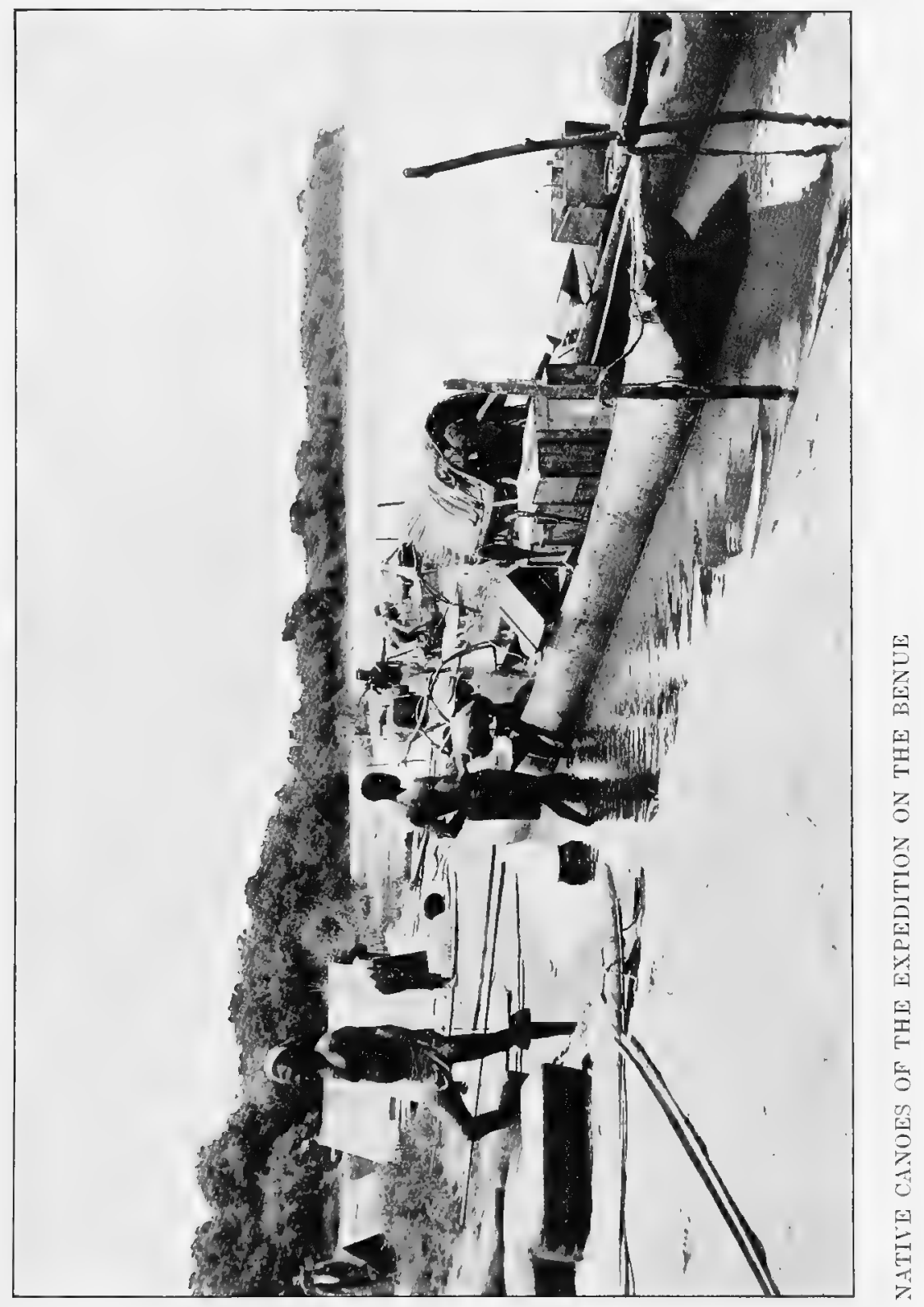



able forethought in the arrangement of the Expedition was the organisation of the transport according to the resources of the countries traversed. Thus, in Nigeria we had to be prepared to raise a supply of carriers, often to be brought from distant centres; and in Bornu reliance was placed entirely on oxen, sometimes supplemented by donkeys; for the Kanuri, who are the chief people of the province, are too proud to bear the white man's loads, and the Shuas cannot be induced to leave their flocks and herds. On the River Benue native canoes were requisitioned. Then, after crossing Lake Chad, our boats had to be depended upon for everything, with the addition of Kotoko canoes to carry the commissariat.

While on the subject of transport it may not be out of place to say a little about the carriers. We are exceptionally fortunate in this respect in our West African possessions, for the Hausa, Nupe, Wongara and pagan Fulani are almost bred and born to the load and, having the instinct for discipline and order, are very easy to organise. So this fine supply of labour is a most important asset in the resources of our territories. In comparison with ourselves, the French are poorly provided with labour, for great stretches of their possessions are very sparsely populated, and in those parts where there are people they are pagan tribes, who are not yet very adaptable to the white man's service. And as far as my observations reached in German territory, I should think that they were not much better off than the French.

The pay of the carrier as authorised by the Government in our West African colonies is very high, so that one should expect good service. It is $9 d$. a day for the work and $3 d$. subsistence money, and to every fifteen men there is a head- 
man who gets $1 s .3 d$, and he is held responsible for the proper service of the men under his charge. It is an interesting sight to see them taking up their work on the first morning of their engagement. All the boxes and packages are put out in line by the "boys," who are responsible for the packing of the things directly under their charge. Then there follows a rush of the carriers who all make for the loads, fighting furiously to get possession of the ones that by their size or convenient shape appear the easiest to carry. And, light or heavy, whatever falls to their lot the first day, remains their burden to the end of the march. A load averages between 50 and $60 \mathrm{lb}$. and they will carry this cheerfully on their heads from six o'clock in the morning till three o'clock in the afternoon with an hour's rest at noon. When working for himself, a native will carry a great deal more, and I have seen them coming down from the interior with loads of kola nut, weighing as much as $100 \mathrm{lb}$. It is a frequent sight to see the foreheads of the older men pressed into deep furrows by the habit of years. And all along the roads, that are the courses of native commerce, at intervals the lower branches of the trees are worn by the loads that carriers have propped against them, supported by the long sticks that they carry, to save themselves the effort of lifting the weight from the ground on the resumption of the march. A pleasing trait to be observed in the nature of the West African carrier is the sense of comradeship, and it is a not uncommon sight to see at the end of a day's trek the older and more experienced hands run on to the halting-place to dump down their loads and run back to take the burdens from the wayworn stragglers. 
The bulk of our transport consisted of our tents, survey instruments, boxes of provisions, bales of cloth and other trade-goods and a large supply of ammunition. All these were stored at the camp, which was our base for the time, and the party split up into various columns, going in different directions for the survey, or hunting, or whatever might be the aim in view, and taking with them their rations that were done up in boxes to last ten days. This was in the early part of the expedition. Later on we had to depend upon the rifle and the food we were able to buy from the natives. We each had a patrol tent of Willesden rot-proof canvas, the only kind that are durable enough to be of any use on an expedition of this character. The pegs were of iron to resist the appetite of the white ants that will eat through wooden ones in a single night. The provision boxes, 120 in number, were a great success and were made up by Lazenby of a carefully selected variety of foods, the result of systematic experiments upon the family circle before starting. Nor must I forget to record the self-sacrifice of the R.B. mess, who on several occasions were called upon to put the life-sustaining properties claimed for certain patent foods to the test, fortunately with no negative results; but that does not minimise their heroism, for how were they to know?

By far the most valuable of all the contents of the provision boxes were the tins of Ideal milk, which proved such an inestimable boon in sickness that after a short time we gave up using it for ordinary consumption, except on rare occasions as a very great treat, and saved it up with our medical comforts, which included Liebig's Extract, Brand's Essence, Benger's Food and champagne. We chose the 
smallest sized tins of Ideal milk, and very luckily; otherwise much would have been wasted by going bad after being opened in the heat. The powder milk was also very good for a certain time, but afterwards the dampness of the climate affected it, and it congealed and would not mix properly. However, I was most grateful for its aid during my attack of blackwater fever. Next to milk, the most important of our foods was jam, for which we all developed a strong craving, for under the exhausting climatic conditions our systems demanded the nourishment of sugar, and we found jam to be the most wholesome form. Other "rational" successes were tinned lunch tongues, sardines, potted meats, Bath Oliver biscuits and various tinned vegetables; these last were most important, as was also limejuice. But all the contents of the provision boxes were most satisfactory, with the one exception of tinned butter.

We were our own doctors, and took out with us two Livingstone medicine chests, the contents of which appear in the appendix. Old experience of the African climate, had given me a rough practical knowledge of the most useful drugs. Of the whole list the medicines that were in most frequent use were quinine, calomel, Epsom salts, ipecacuanha, iodoform, and corrosive sublimate. Quinine as a precaution against fever was, of course, in constant use among ourselves; but the drugs that we found ourselves most often administering to the "boys" and carriers were calomel on the morning after a meat debauch, and iodoform and corrosive sublimate for sores and injuries to the legs and feet, the last was particularly efficacious in killing guineaworm, which was very prevalent among them in the wet 
season. It was some time before they could be got to come to us for treatment and their faith stuck for long to their own cures, which were often strange and always primitive. Thus, for guinea-worm they would put on chopped leaves plastered over with cowdung, which generally had the effect of inflaming the part very much; and for headaches they tied a string, rubbed in the juice of some leaf, tightly round the temples; and gashed with a knife any part of their bodies where they suffered pain to let blood. At times there was a good deal of sickness among the men, especially when the Expedition came into touch with large villages and stations, and the way they always attempted to avoid coming up for treatment led to such serious results that we were obliged to institute medical inspections, with serious penalties for the concealment of ills.

Before leaving the subject of hygiene, there are two articles to which I wish particularly to refer, the one that it may never be forgotten by the intending explorer; the other, that it may be excluded from his equipment. These are the hot-water bottle and the filter. In all cases of sudden colics and fevers, the hot-water bottle for alleviating pain and starting sweats is a priceless boon, which we gratefully hugged to ourselves on many occasions, while the filter, owing to rough usage in transport or the carelessness of the "boys," gets broken or becomes the breeding-pen of disease germs. So that it is not only useless, but also dangerous and therefore ought to be abolished.

Besides the many packages of trade goods, we had a large amount of photographic material, including a dark tent and five cameras. We took both plates and films, but the former 
were by far the more satisfactory, resisting the trying conditions of climate better. Of course, the photographs dealing with the first part of the expedition have yielded the best results and hundreds of the later plates turned out worthless; but, personally, I am much surprised that any at all of these have been rescued, remembering the length of time they had to endure and the strange vicissitudes that they went through. A large and heavy part of our equipment were the survey instruments, including two theodolites and a telescope, which needed most careful carrying. But heaviest item of all was the ammunition, made up of 15,000 cartridges of all kinds.

I must not close the list of our belongings without making mention of two machines, with the utmost gratitude for their invention, namely a gramophone and a mincing-machine; but I do not wish for one moment to suggest, by mentioning both in the same breath, that they performed similar functions; they merely occurred to me together, as being, each in its own way, triumphs of the inventor's skill; for the one carried for thousands of miles from the fount at which it was filled charms to soothe the savage breast of the explorer, while the other by a turn of the handle charmed wild beasts into a form that was pleasant and digestible.

I also took out a phonograph, in the hopes of bringing back interesting records of native languages and music. The results were most satisfactory while out there; but, unfortunately, the cylinders got ruined by damp on their way home. In my intercourse with the chiefs it had the most wonderful effects. It invested me in their eyes with the powers of the devil. On one occasion that $I$ remember, 
I took records of the bugle calls in the garrison at Bauchi, and, not thinking of the consequences that would naturally follow, turned them on one still night in the house that I

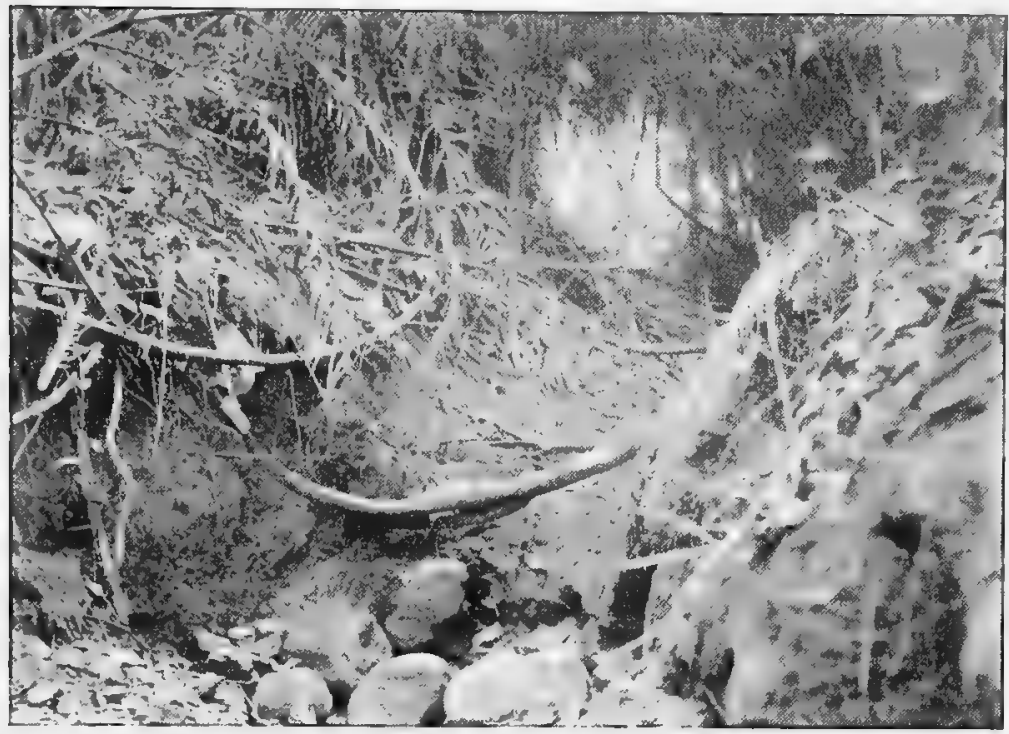

THE SOURCE OF THE NIGER

occupied, with the eff sct that the whole garrison turned out to the alarm.

At last the approval of our scheme by the Colonial Office was gained, and, backed up by the Intelligence Department, we obtained the sanction of the War Office and were seconded from our regiments without pay. The Colonial Office gave us the magisterial powers of Assistant Residents while in the Nigerian Protectorate, and a free passage into the country for all our stores.

So now everything was in readiness for a start and, having sent on José by a previous boat to collect "boys" at Cape Coast, where he subsequently joined us, bringing 
with him John, our excellent Senegalese cook, we set sail from Liverpool on February 27, 1904, on board the s.s. Olenda and arrived at Forcados, the mouth of the Niger, on March 18. The Olenda, owing to the strong current, overshot the river mouth in the night by over thirty miles and had to beat back. We then transhipped into a branch boat which took us into the roads, where all our baggage, some 400 loads, was transferred the next morning to a Government sternwheeler for our journey up the Niger to Lokoja. 


\section{CHAPTER II}

\section{OUR JOURNEY UP THE NIGER AND BENUE}

After ninety miles the Forcados joins the Niger, whose main stream one sees flowing away to the right, from this

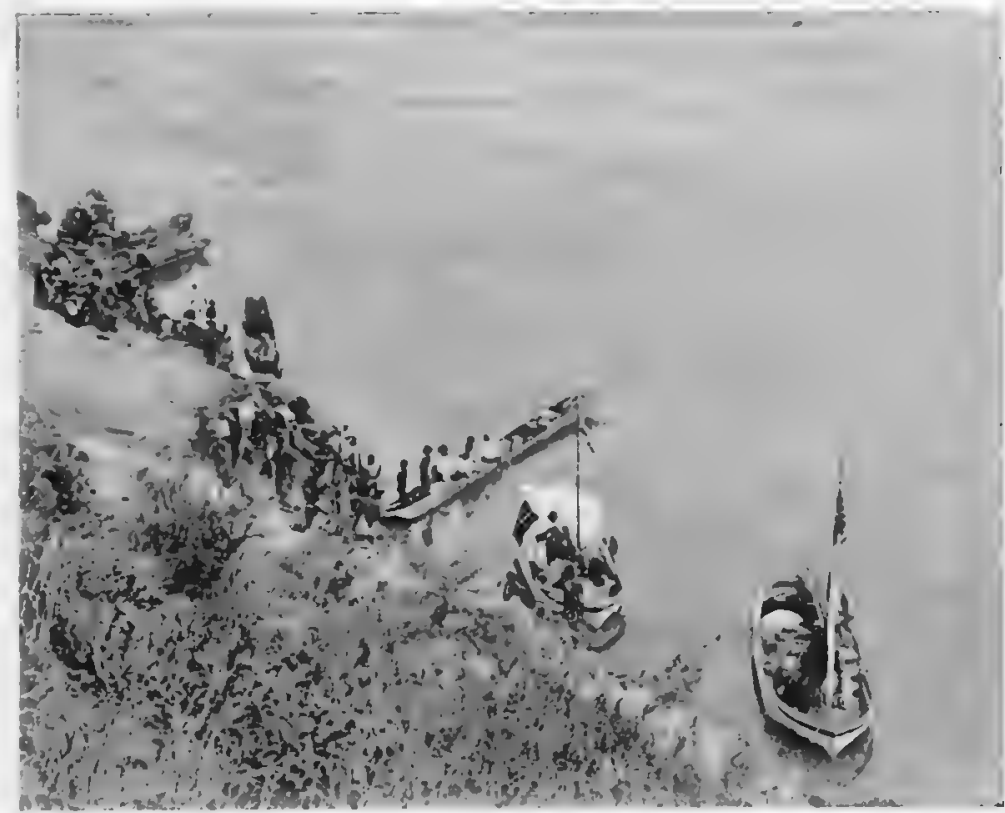

THE EXPEDITION ON THE RIVER BENUE

point to be called the River Nun. Here the river broadens to a width of 800 yards and sand-banks begin to appear in its course. The river banks, which in some places rise to a height of 20 to $30 \mathrm{ft}$., become less densely wooded and the 
trees are of a finer growth. This country is inhabited by the Ibos, a people of low type. They are agriculturists and grow yams, rice, corn, plantains and palm oil, and rear small numbers of goats, sheep, and fowls.

After leaving Abo, a village of this tribe, where we anchored for the night, we saw a strange sight of thousands of giant bats, that circled in crowds as thick as starlings over a grove of cocoanut palms, their furry, tawny bodies lit up golden in the early morning sun. Their activity at this unusual hour for twilight creatures evidently betokened some sudden and abnormal swarming of insects that were their prey. These bats are the denizens of the rivers, and sleep hanging on the branches of the thickest-leaved trees. Often on our journey, when the passing boats shook the boughs of an overhanging tree, I recall how the sudden, silent flash of gold, flickering for a moment in the sunlight to disappear swiftly into the depths of some dark tree ahead, reminded me of the little gold moths that dart from the thick ivy coverings of old walls at home.

A little beyond Abo the country becomes more open and the tall trees recede from the banks, leaving spaces covered with low bush and tall fish canes.

We anchored for the third night at Onitsa, a fairly large village belonging to the Egara tribe. These are fisher folk, and further up the river we came upon their small grass huts upon the sand-banks, where they come to fish in the dry season. But when the river rises in the rains the sand-banks are flooded and the Egara retire to their settlements inland.

Often we saw numbers of vultures on these islands, huddled asleep after their gorge of fish refuse, and heard the 
beautiful cry of the solitary fish-eagle, which we now and then surprised at his fishing, perched on a snag or dead tree limb. There were pelicans, too, upon the sand-banks, and sleepy-looking ibis in little crowds to add variety to the bird life of the river. And sometimes our approach disturbed a flock of beautiful white egrets which would spread out over the water in a little white cloud and circle back on to a tree where they hung like clusters of white blossoms.

Thirty-five miles from Onitsa the river widens to a breadth of two and a quarter miles, flowing through open bush country, and at Ida, on the boundary between the two Nigerias, small hills about $800 \mathrm{ft}$. high, appear in the distance like whale backs rising above the plain, covered with leafless trees which our eyes rested on as a pleasant change after the endless green that had lined the course behind us. So, the aspect of the river continues as far as Lokoja, where we arrived on March 24.

We spent a week at Lokoja in very comfortable circumstances, as the guests of the 2nd Batt. Northern Nigerian regiment commanded by Major Merrick, who was extremely kind to us, as was also Capt. Elliot, Superintendent of Marine, who spared no pains in helping us fix the boats together and in procuring us polers for the journey up the Benue. Here we added to our personnel an old Hausa called Galladima, who became our quartermaster, and Umuru, who was appointed gun boy to Gosling. Also Quasso, first of all my brother's " boy" and afterwards mine, and Lowi, a Yoruba, who became "cook's boy" to John, are worthy of mention as characters who afterwards appear in our history. We also got together forty carriers, who followed the boats with 
a great part of the baggage in five large canoes. I have forgotten to say that five others preceded us with the bulk of the stores. The native dug-outs play an important part on the River Benue, which owing to its navigability is the chief trade-route of the country round. They are sometimes $30 \mathrm{ft}$. long, and are manned by eight polers. We spent the time, while the boats were being put together and the required number of carriers collected, in getting the survey instruments into working order.

We left Lokoja station at 4 P.M. on March 31, passing the native town an hour later. Owing to their being overloaded, the boats seemed very unwieldy at first and made slow progress. At 6.30 we anchored on a sand-bank about a mile up the Benue, beyond the point where it flows into the Niger. Here we pitched camp in heavy rain, and supped off tinned rations, as it was impossible to light a fire. Next morning we made up for the lack with a good breakfast of porridge, bacon and eggs, and then proceeded to repack the boats, that had been overloaded the day before.

For the first few days progress was slow, for the polers took some little time to get used to the handling of the boats, and, moreover, they and the carriers required a few lessons in discipline; also they had to be taught that we were not altogether ignorant of their ways. A sharp look-out had to be kept on their dealings with the natives along the river, whom they took every opportunity to plunder under pretext of being emissaries of the white man. But, by making one or two salutary examples, we soon got them well in hand. Then our pace improved and we made on an average about fifteen miles a day. It was our practice to start moving about half- 
past six in the morning, working steadily on till eleven, when a halt was called for "chop," and a rest for an hour. Then our way was resumed, till about 3.30 in the afternoon, when a camping-ground was selected with plenty of time to get tents pitched and our meal cooked before sundown. I am a firm believer in regular times for meals and rest in African travelling, both for oneself and one's "boys," who I have always found work better and are more contented as a result.

The Benue is a fine navigable river all the 200 miles to Ibi, with an average depth of 4 to $5 \mathrm{ft}$. during the dry season, and a current of four miles an hour that made poling fairly hard work, and there were great many sand-banks to be avoided. Where the river narrows, the high banks are finely crowned with luxuriant trees, but its prevailing width is a thousand yards at which parts the banks are low and a view is obtained of an open bush country, interspersed with cultivated millet fields, with here and there the skeletons of trees that have been blasted in the bush fires. These were the favourite rallyingpoints of brilliant blue jays that flickered on and off the dry dead boughs like spirit flames in the sunlight. In places along the higher banks the bare mud sides are honeycombed with the nesting-holes of hundreds of scarlet bee-eaters, which on a sudden at the signal of the boats approach, bristled with pointed bills and went off like a battery of guns, shooting out their live charges with red shrieks into the air.

Here I will quote an extract from a letter of my brother's, as giving a little picture of the river and our life upon it:

"We have been doing a good fifteen miles a day of eight hours lately, and altogether travelling incomparably quicker 
and more comfortably than at first, the reason being that our rather motley crowd of boats and crews took some days before they shook down and began to pull all together. The whole expedition is in the best of health; myself, I have never

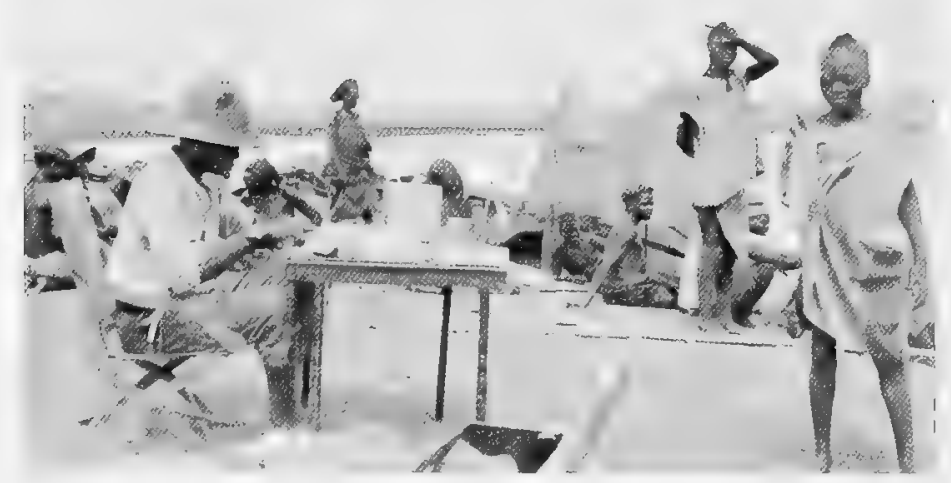

JOSE SKINNING BIRDS

been better. The Lazenby provision boxes are excellent and each one holds out much longer than it was expected to do, although all the game we have got has been a hartebeest and a certain number of guinea-fowl. I can't make out why we have had so little to shoot. Every one had said that the country just about here was simply teeming. Almost every afternoon and evening all five of us have scoured the country for three or four miles around, and, although there have been signs of plenty of buffalo and antelope, no one has fired more than a few long shots at them. Two evenings ago, after four hours walking, I found a herd of about twenty 
large antelope. A long stalk failed to bring me within 300 yards of them. 'Bee' is well pleased with his birds; he has over fifty choice skins, with some good things among them, he thinks.

"The Benue scenery has varied little the whole way. The country has been quite flat, with hardly a glimpse even of hills. I should think that the average breadth of water has been a thousand yards, bounded on one side by broad stretches of sand frequented by big jabirus and other storklike birds, geese and plover and occasionally a crocodile: on the other a steep crumbling mud-bank about $20 \mathrm{ft}$. high at the present state of the river. If one climb this one gets at once into a narrow belt of wood, which is often too dark for there to be any undergrowth. One can walk for miles sometimes without any worse obstacles than the thick crackling bed of dead leaves that make enough noise to scare away any living thing for miles. Only the innumerable small birds and monkeys seem to have enough curiosity to wait and see what's coming. I often heard the big baboons that seem to keep well in the background; but José got a very fine skin of one which is now drying on the top of the boat's awning. These woods often form our dining-room for afternoon 'chop,' as soon as it is decided to stop for camping, when the tables and chairs are put out under a dark vaulted roof of evergreens. In the meantime the tents are being pitched on the sand-bank below where the temperature in the shade has generally been found to be from $100^{\circ}$ to $105^{\circ}$. We find that the sand cools very quickly after sundown and that then our tents are in far the best place for sleeping, as they are more in the way of the currents of air made by 
the river. Beyond the belt of wood there has nearly always been the typical African bush and it is much the same here as in South-east Africa. Most of the elephant grass, which is thick, woody stuff like bamboo, has been burnt and the fresh green is now ankle-deep. The bush reminds me very much of old orchard land. Sometimes one feels one would never get tired of exploring its endless succession of nooks and glades."

The skin that my brother refers to in his letter was that of a very fine dog-faced baboon, which caused much excitement among the "boys" when it was brought into camp, as they had not had meat for days and to watch them wrangling and jabbering over the carcase made their devouring of it seem almost a degree of cannibalism.

There was not much incident about our journey up the Benue, for, as my brother's letter has described, there were no excitements of the chase. Of course, in those early days of the Expedition every little thing made a deep impression at the time upon us all, for our senses were strung to a keen pitch of observation and our minds recorded pictures that were beautiful and strange; but their colours and details are all given in the word-African river, and appear to me now rather distant and blurred behind the crowd of events that gathered afresh with each succeeding day. Sometimes the others found relief from the monotony of sitting in the boats for miles of changeless river and got grand exercise by poling. My brother was especially keen at the work and would stick to it for hours at a time, stripped and ready to dive and retrieve the birds I shot from the boat. He was also very fond of bathing and used to go down with José daily, as he 
himself described, "all naked to the hungry croc," while the boys beat the air with the poles to scare away the unwelcome companions of the bath. I remember how once he

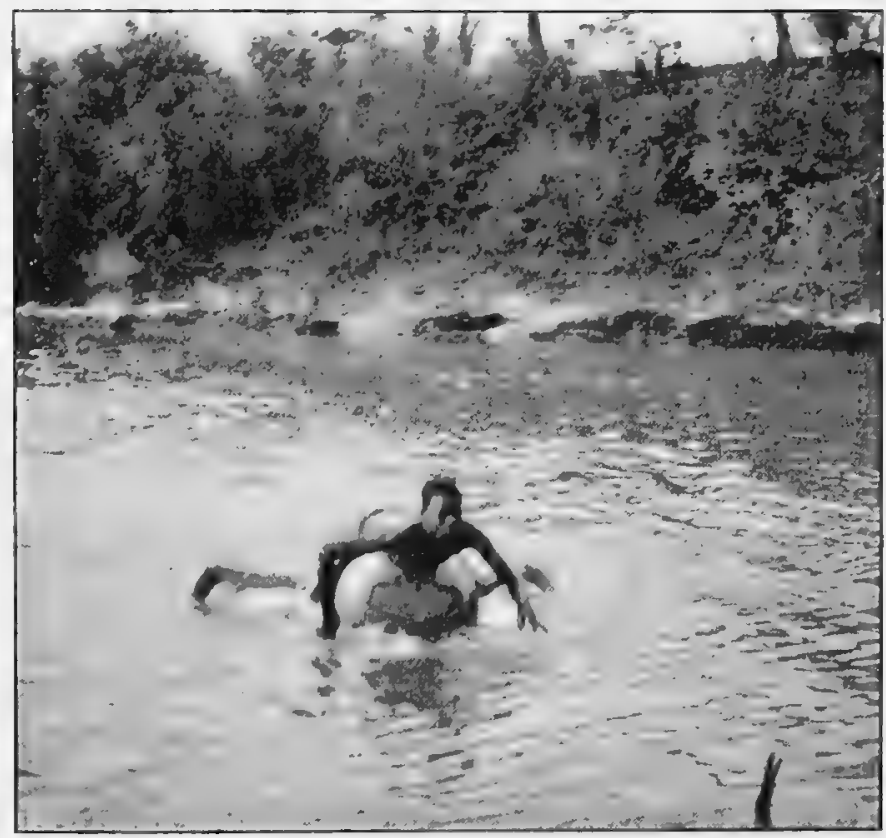

CROSSING THE RIVER ON A GOURD

spent the greater part of a day, paddling himself about, native fashion, naked on a large gourd, enjoying himself hugely at the time, but at night he suffered terribly for his contempt of the sun. When he went to bed he was feeling very sore from sunburn, and presently-to use his own description-the pains of hell got hold upon him and he was burning red from head to foot and his skin swelled and rose up in huge water-blisters that kept him in acute torture for days, for he was literally flayed alive.

As we journeyed in the boats, a good deal of work was 
done in writing up notes and working out computations from the star work of the night before, while I was busy skinning my birds. Hour after hour the boats toiled heavily along against the stream, generally following about 800 yards apart; but sometimes they drew level, and this was always a signal for a spurt from the crews, and for a few minutes we were gripping ourselves in the excitement of a race, that determined which was to be the leader of the river, and so be the first to turn the bend that we ever hoped would disclose a fresh scene, or arrive first at the welcome point chosen for the camping-ground. For the first few hours, when the day was cool and all our energies fresh, we would notice every little incident of wild nature along the banks, and frequently the banks echoed to the report of my gun, which had been aimed at some rare object I had spied through my glasses. But as the day wore on, and the water and the dry mud-banks began to glare and quiver in the heat and one's senses to grow confused with the monotonous sound of the polers working, one's thoughts started to stray and one's eyes stared in front of them without intelligence, fascinated by the endless heat dance over the water or the muscles of the backs and limbs of the polers which seemed to swell bigger at each lunge as the sweat started to spring, making them shine like wet bronze in the sun. Thus one's mind was lulled into a state of torpor, and hours went by unheeded till, perhaps, suddenly round the bend of the river, or in the distant haze at the end of a long reach, a native "dug-out" appeared, and one was startled alert by a shout from the "boys" and the boat leapt forward with a sudden spurt. Long before we neared each other questioning shouts and answering shouts would 
go echoing across the water to increase into a babel of noise as we passed the length of the canoe, and its crew and our polers recognising each other, would excitedly pour out the

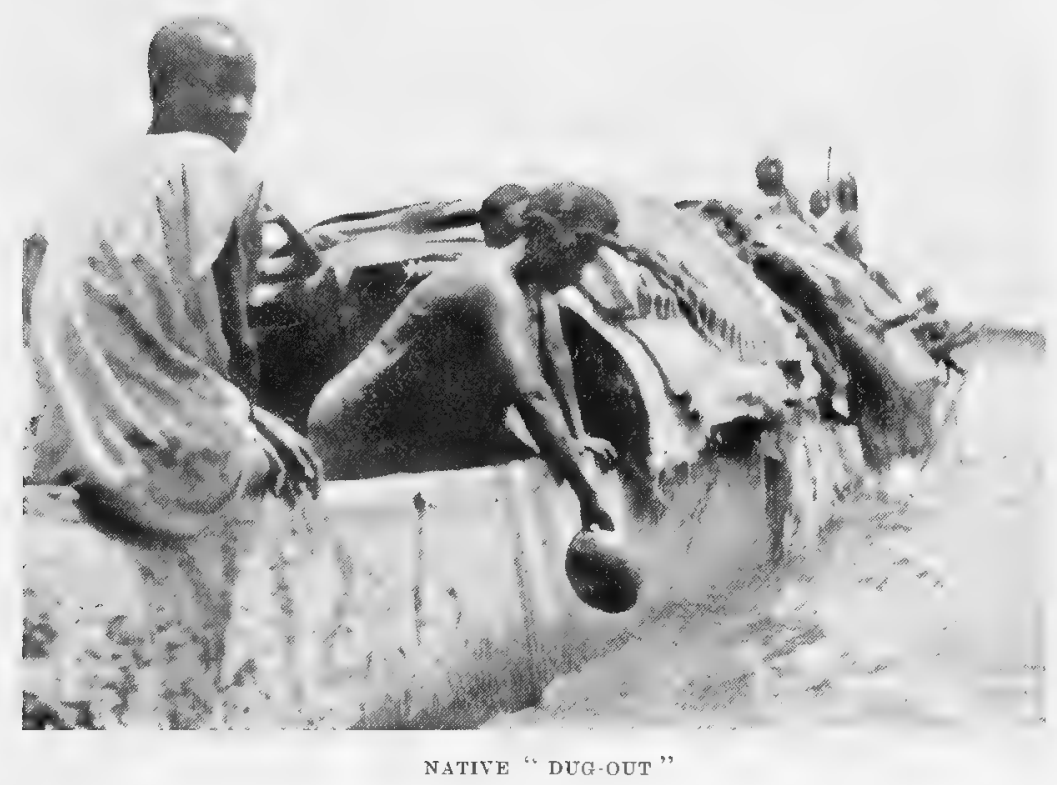

news since their last meeting, keeping up the interchange to a last shriek as the canoe passed out of sight in the distance. The canoes or "dug-outs" of the Benue are splendid boats of some $30 \mathrm{ft}$. hewn out of one tree. The one in the accompanying photograph was very typical, and was carrying a crowded cargo of passengers and yams to Lokoja. Beneath the awning of zana matting, women partly draped in striped and gay coloured coverings were sheltering from the fierce sun, and the men lounged lazily along the sides, while the 
canoe drew its length slowly down stream, jerked on by the exertions of a small naked boy who sweated and panted as he struggled at the end of a long pole, while another worked continually baling out water with a calabash. A thin column of smoke curled up and drifted away behind from the fire in the bows, which was boiling water for their mid-day meal. The native owners of these canoes take up contracts with the Niger Company to carry trade goods up the river to their stores. They then fill up with a cargo of their own or take passengers on the return journey down stream. Sometimes the canoes are filled with sheep and cattle, and sometimes they carry hidden cargoes of boys and girls to be sold for slaves at the Lokoja market.

About half-past three in the afternoon we would select a site for our camp for the night, generally on a sand-bank; and there was much work to be done, pitching the tents and unloading the boxes from the canoes that all leaked badly; then there were the rations for the "boys" to be given out, consisting of one pound each of ground millet, some of which they saved for their morning meal. Parties were sent out to gather wood for the fires, and after a cup of tea, we ourselves set out hunting or collecting in different directions with hopes, which were at this time seldom realised, of getting a change of food for the evening meal. To this we sat down after a warm bath, at six o'clock. Then, when the nights were fine there were several hours of star work, always greatly impeded by the swarms of insects that came round the lamps in clouds, getting in one's eyes and darkening the lenses of the instruments.

The Benue is well populated throughout its course, but the 


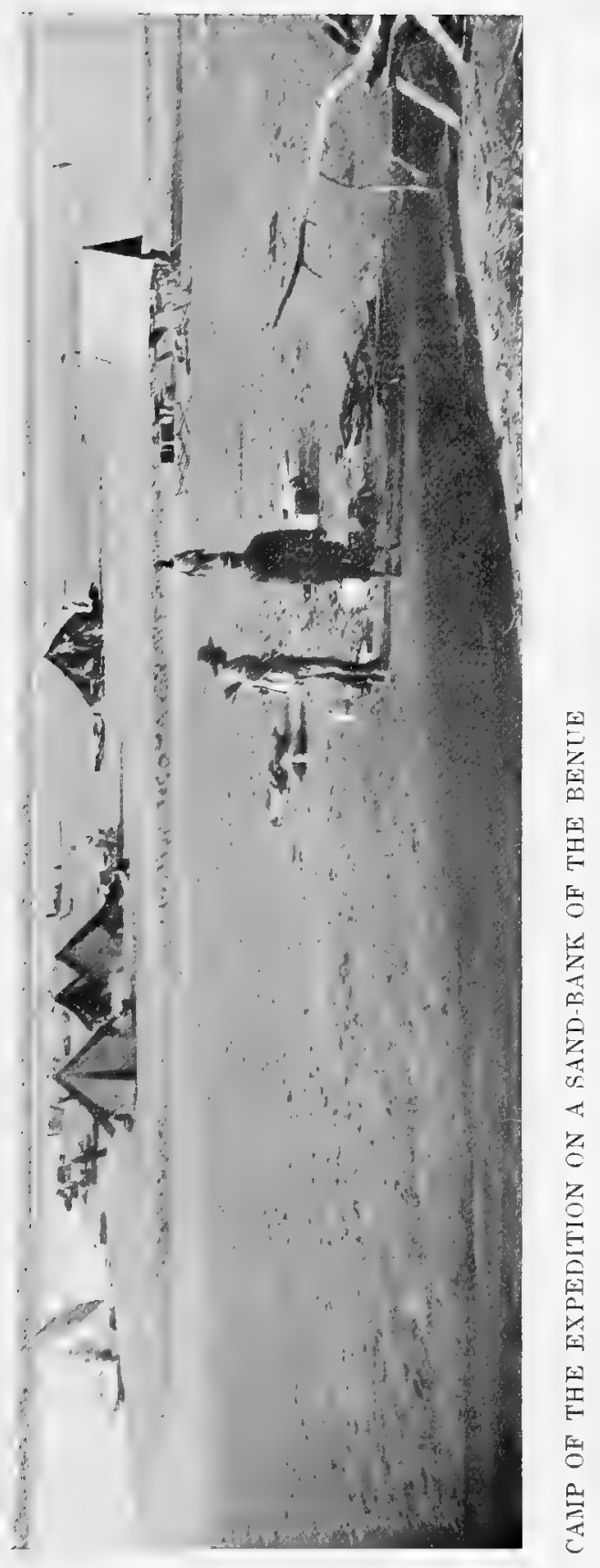



villages lie for the most part on the northern bank. These have mixed populations, chiefly Hausa, Agatu, and Nupe who have settled there for the convenience of the caravans, that avoid the inhospitable country of the Akropoto and Munchi tribes that inhabit the regions along the southern bank. Of these the Munchi are the most interesting. They are a wildly picturesque-looking people, black even for Africans, and of hard and stringy muscular build. Their clothing goes no further than a matter of form, and they arm themselves with bows and poisoned arrows. In features they are typical Bantus and bear a striking resemblance to the Boobi of Fernando Po and the natives of the Cameroons, who are other tribes of that race. No doubt at one time they were all one people inhabiting the coast regions, and were driven inland by the slave-traders of America, whose vessels came raiding for their fre'ghts of human merchandise up the Cross river. Perhaps their unfriendliness to the white man to-day is largely to be traced to the traditions of their persecution in those unhappy times and to the abuse of native traders, so that ever since, their attitude has been hostile to the white man and the trader, with the result that the resources of this rich and fertile country, producing rubber, gum, and ivory, are not yet opened to trade. The supply of beniseed, which is an important product in the trade of the Niger Company, is entirely dependent on the Munchi, who bring it in or not as they choose; the same is the case with yams in the markets along the river. Often these markets are held on the sand-banks in the stream for fear of the possibility of a Munchi raid. The cry of "Munchi!" is quite enough to cause an assembled market 
to scatter broadcast, the women rushing about in the direst confusion, snatching up their wares in the endeavour to save them as well as themselves.

The name, Munchi, was given to them by the Hausas who tell the following fable concerning them. When Allah visited the country where the Munchi now live-to see how the tribes which he had placed there were getting on, he found the Bantu in sole possession, and when he asked them what had become of the original people, they replied, "Mun-chi"-(we have eaten).

The Munchi are excellent farmers, and their farms are beautifully kept and form a striking contrast to those of their northern neighbours. They are also born hunters, and their method of getting near their game is extremely clever. Covering their heads with the mask of the ground hornbill, swaying to and fro after the manner of the bird, on hands and knees they approach their quarry within a short arrow's flight.

Gosling in his diary records an interesting conversation on the subject which he had with Alexander Taylor, a Scotch elephant hunter, who had spent many years in the country. "He hates the Hausa as a lying, lazy, underhand man who tells the pagans awful stories about the white man and trades on this. For instance, a trusted messenger was sent out to him from Ibi with letters. On the way he took the opportunity of his being in the employ of the white man to demand three slaves of a town he passed. These were given him, but fortunately he was discovered. Slave-raiding is constant down this way, and slaves are the only things that will buy ivory. The Hausa trader comes along, seizes smail 
boys and girls when he can, and sells them for ivory at the native markets and the ivory he sells to the Niger Company. Meanwhile the Munchi having got his slaves, as the only price he will take for his ivory, sits down at ease among them

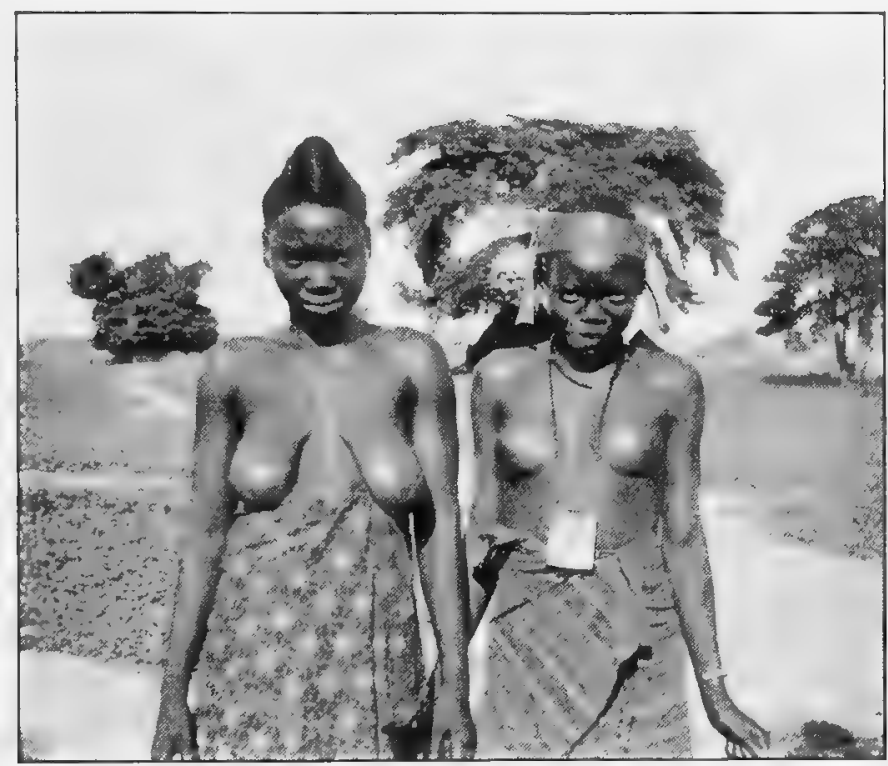

JUKUMS AT WUKARI

doing nothing but enjoy himself till he feels inclined to go out hunting again. The Munchi hunter's method of killing an elephant is to get directly behind him and fire a very big, strong poisoned arrow out of an old flint-lock between the legs where the skin is thin. They then drop the gun and run. The elephant is dead in an hour. Taylor went on to say that the Munchi who are pagan cannibals are as nice a people to deal with as any other. They have fine open countenances and firm chins. They only tried to spear him once, and then he was well revenged with the assistance of six other friendly 
cannibal towns. Their religion is the worship of their ancestors, who are eaten when they die. When asked why they eat human flesh, they reply that they have always done so. They are strict observers of the laws of hospitality

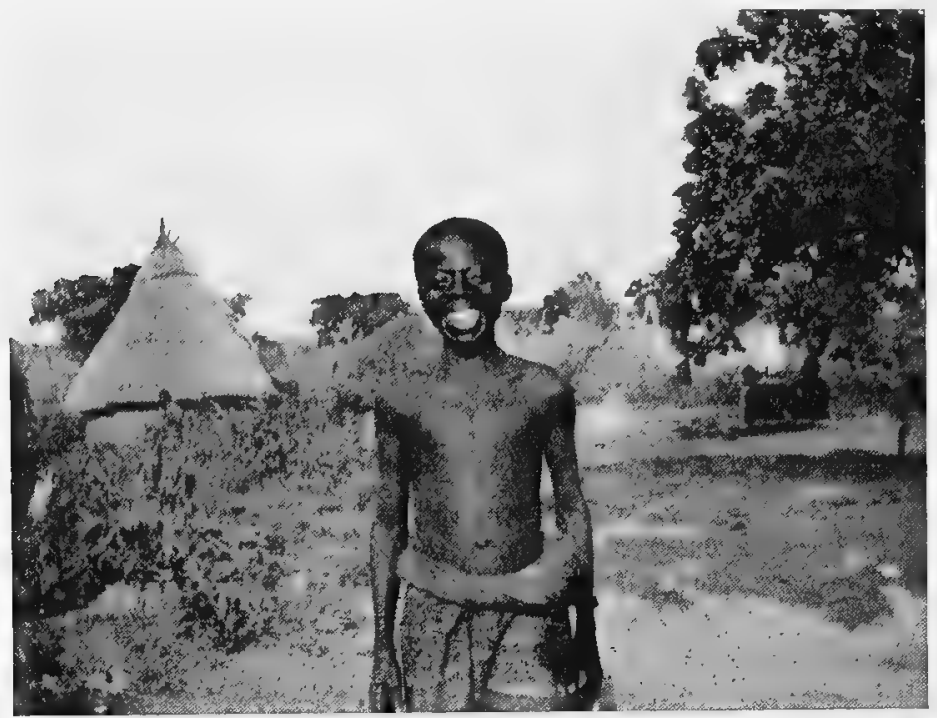

GOSLING'S LITTIE CANNIBAL FRIEND

and, as long as he is under their roof, will feed and protect the man whom they will afterwards waylay and attempt to murder.

"The Germans seem to know little of their country except a short distance on either side of their main route up to Garua. Here every village is deserted on account of the excesses of their native soldiery.

"The only way of stopping slave raiding seems to be to close the ivory market by international agreement. The white man is allowed to kill only two elephants a year in a sporting way, while the native hunter kills them indiscriminately. 
Taylor went on to say that slaves are occasionally to be seen here (Wukari) in the market for sale. He has also seen them shackled together in the bush. Taylor had with him a little five-year-old cannibal boy to whom I showed pictures of animals. The one idea they suggested to him was food, and he pretended to shoot them and put them in his mouth. . . . As I write he thinks my new brindled pup, whom I have christened 'Wuka,' would be good to eat. Dogs with them are about as popular as human flesh. . . Apart from a certain amount of cannibalism, they are quite a moral people. All their wants are supplied at their door, and directly their crops are gathered, they go raiding one another. But this is only like a game to them, and the slaves they take are well treated and are not made beasts of burden and an article of trade as with the Hausa. The girls are married at ten years of age and have families of three or four."

Later on, Gosling's notes on the Munchi people were borne out by observations made by José on a journey to Tarkum, where I sent him to collect during my convalescence after my attack of blackwater fever. The first place he came to was a Munchi village, where the people at first showed a hostile attitude towards him, gathering round with fingers upon their bowstrings, and the king refused to come out and meet him. But an old Munchi hunter, who understood Hausa, hearing José talk to his "boys," came forward and spoke with him. On learning from José that his mission was a peaceful one, and that he merely wanted to go through their country to hunt, being a keen hunter himself, he became very friendly, and after pacifying his people, offered to take José to the places where game was to be found. 
At the first sight of the Munchi, José was instantly reminded of the Boobi of Fernando Po. In their type and even in their gestures they were identical, and in their habits, too, for some of them had their bodies smeared over with red clay, a custom that is common with the Boobi, but which does not obtain with the neighbouring tribes of the Lower Niger region. The Munchi and the Boobi have also one great weakness in common, and that is drink, which, next to hunting, might be called their ruling passion. A spirit is extracted from the millet, with which they repair on certain days of festival to the compound of the king, where they drink themselves into a happy state of oblivion. José, whose object was really to collect birds, thought it wise to make himself popular by first shooting some meat for the Munchi; so he followed the guidance of the old hunter, who led him to a pool, the marge of which was covered with the spoor of hundreds of animals. It was wonderful to see the old man go down on hands and knees and submit the marks to an exhaustive process of selection, quickly taking up a track to reject it as quickly, and finally going off like a dog on the scent, bidding José follow for a quarter of a mile to where, sure enough, there was a herd of hartebeest grazing. José then stalked and brought one down with a good shot at 200 yards. He felt a little disappointed at the rather moderate praise of the old hunter, who said that José had done well for a white man and then offered to give an exhibition of his native prowess. Accordingly, he fastened on his head the head and neck of a hornbill in the manner I have before described and with arrow laid on bow, crawled on his knees close to the herd from which he singled out a male, and started to approach it, swaying his 


\section{OUR JOURNEY UP THE NIGER AND BENUE 37}

masked head from side to side in imitation of the hornbill with masterly pantomime. By these means he got to within twenty yards of his quarry, when he fired, striking the animal

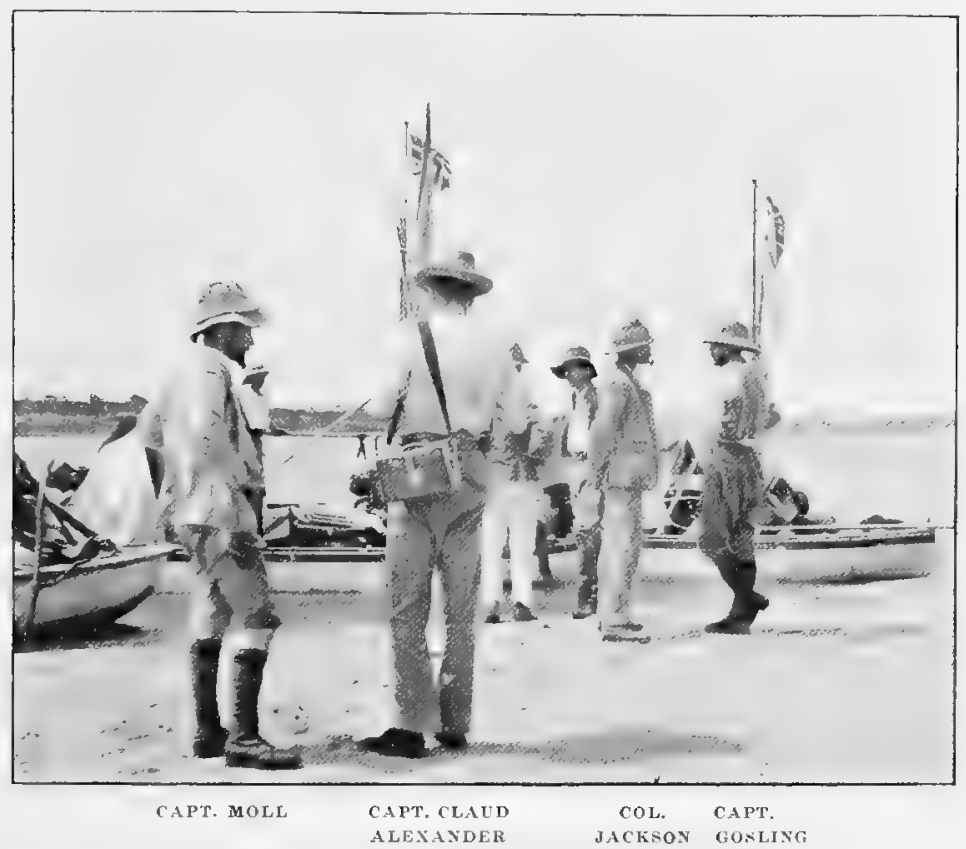

MEETING THE ANGLO-GERMAN BOCNDARY COMMISSION

in the shoulder. It sprang away a few yards, then spun round and fell instantly killed by the deadly poison of the arrow.

Just before reaching Ibi, we met the British members of the Anglo-German Boundary Commission under Colonel Jachson, who entertained us most hospitably at luncheon on a sand-bank, where we foregathered pleasantly, interested in the account we were able to glean from them of the country that lay before us, from which they had just come. We 
arrived at Ibi on April 18, glad to be through with the rather tedious journey up the Benue, and realising that we

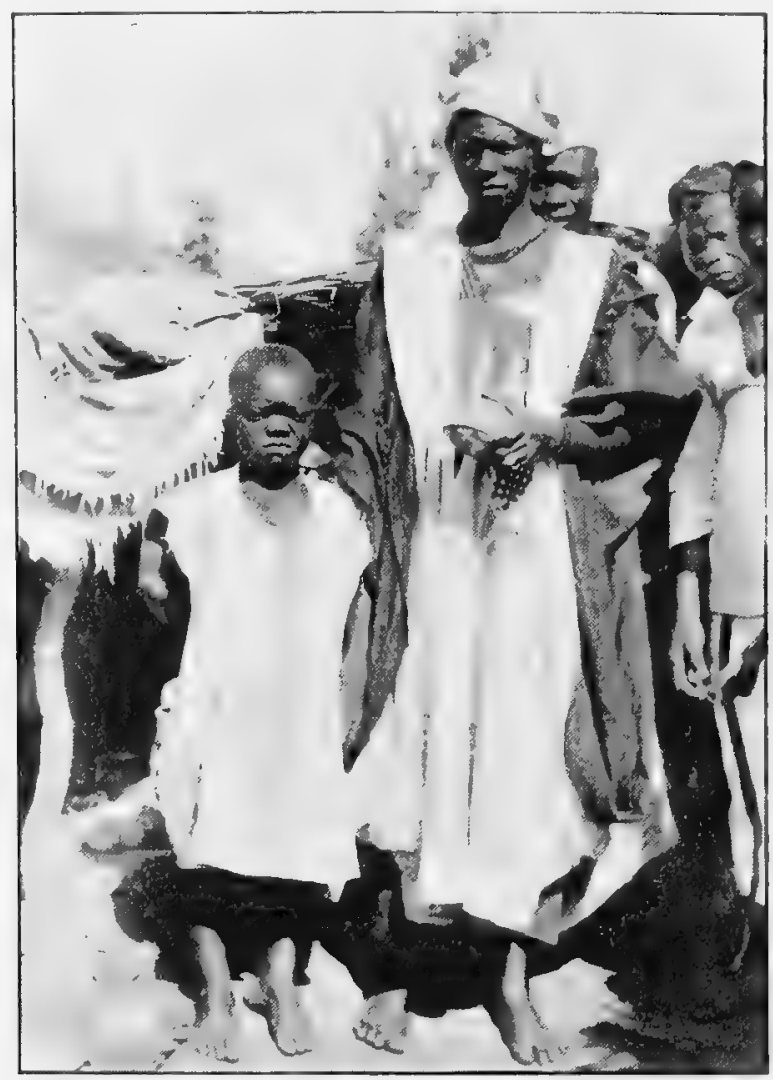

UMURU WITH A DWARF IN IBI MARKET

had reached the jumping-off point whence our work would commence in real earnest.

Ibi is the capital of the Muri province, with a population of 6000 , of all sorts and of all tribes, who are drawn to this, the central market of the Benue, from Bornu, Yola and the tribes south of the river. As in the case of all towns that 
OUR JOURNEY UP THE NIGER AND BENUE 39 are made up by the mixture of races, it is a hotbed of vice. Ibi was an important and one of the most distant posts in

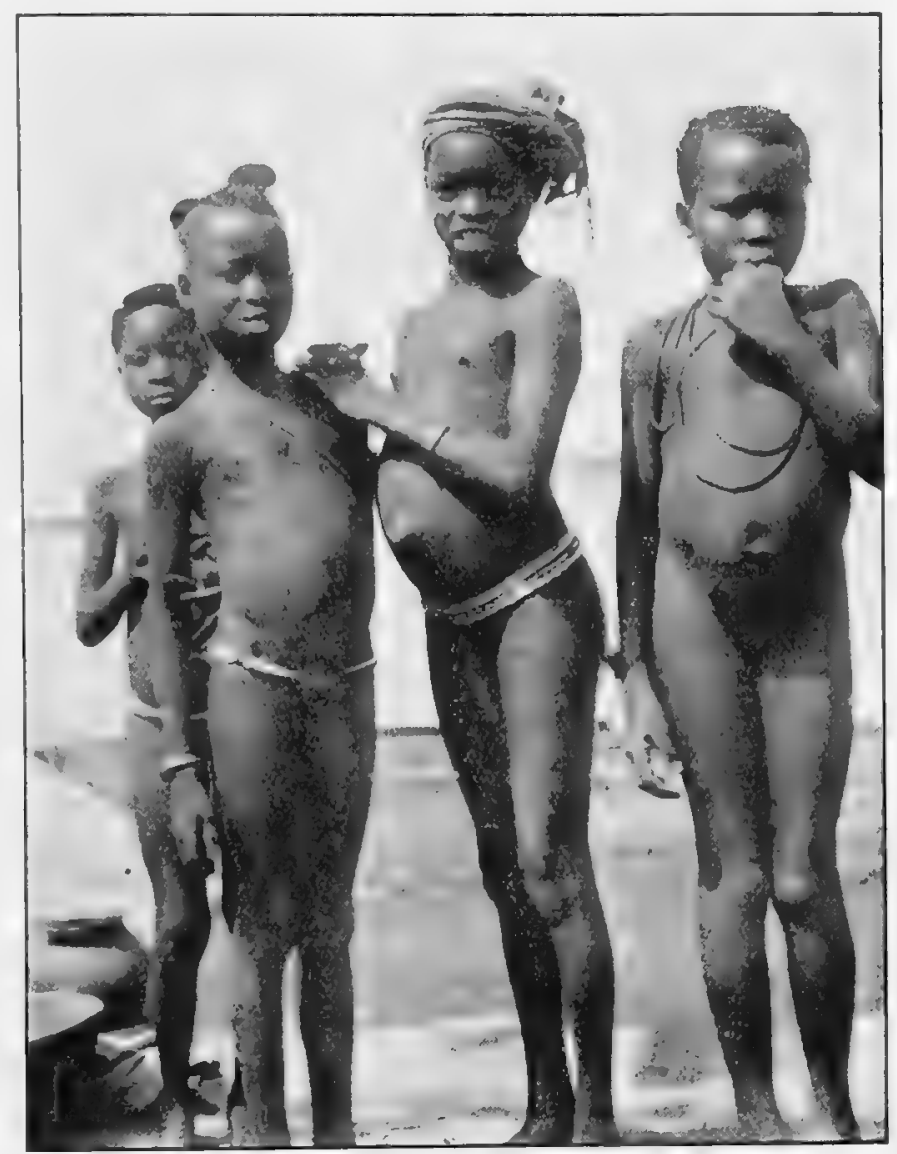

JUKUM GIRLS AT IBI

the old days of the Niger Company, whose history of dangerous endeavour as pioneers of African enterprise is here told by the graves of many of its servants.

Before we reached Ibi the idea of operations we had in view was to get across country as quickly as possible, only 
making astronomical observations, and then to spend the greater part of the time in mapping the region north of the Gongola, connecting that with Kukawa and Lake Chad. We

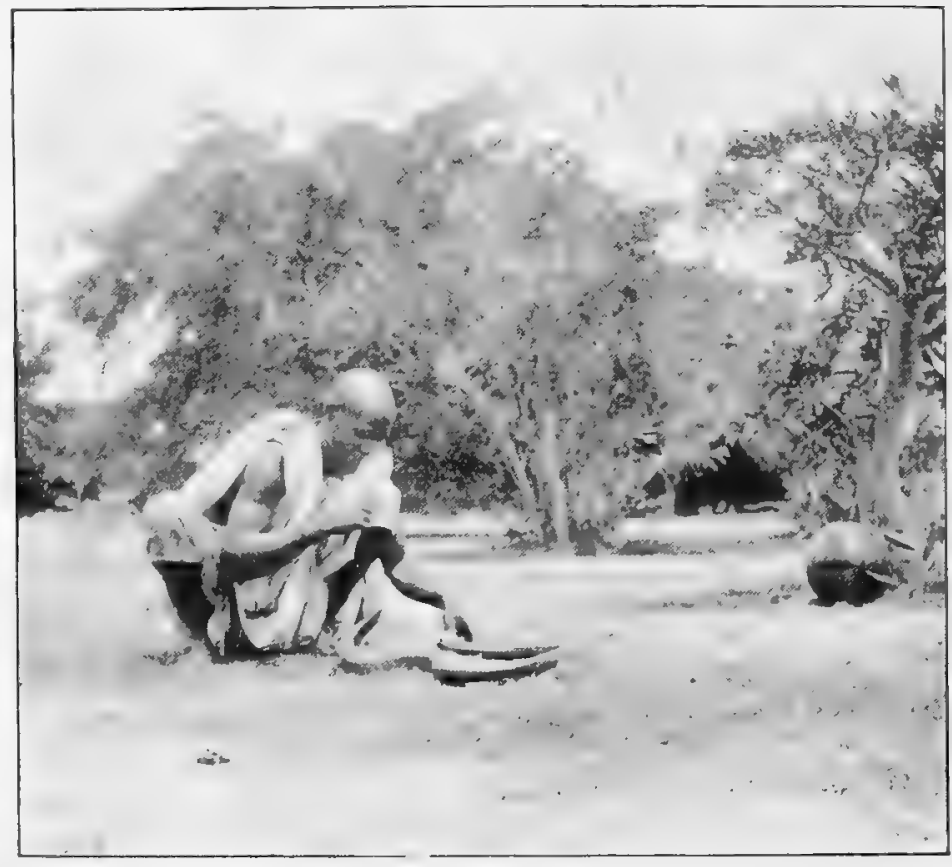

SNAKE CHARMER AT IBI

afterwards decided, however, that it would be more useful under the circumstances to carry the connection with Ibi right through, and in a more accurate manner than merely by chronometric longitudes.

We spent many days at Ibi getting the survey instruments into thorough working order and fixing the position of the place itself. Meanwhile Gosling had gone northwest across the river on a hunting expedition to Lafan Gisseri, a pluce about fifteen miles from Ibi, where he describes 


\section{OUR JOURNEY UP THE NIGER AND BENUE 41}

the country as park-like and abounding with kob and hartebeest. There was also much old spoor of elephant, hippo,

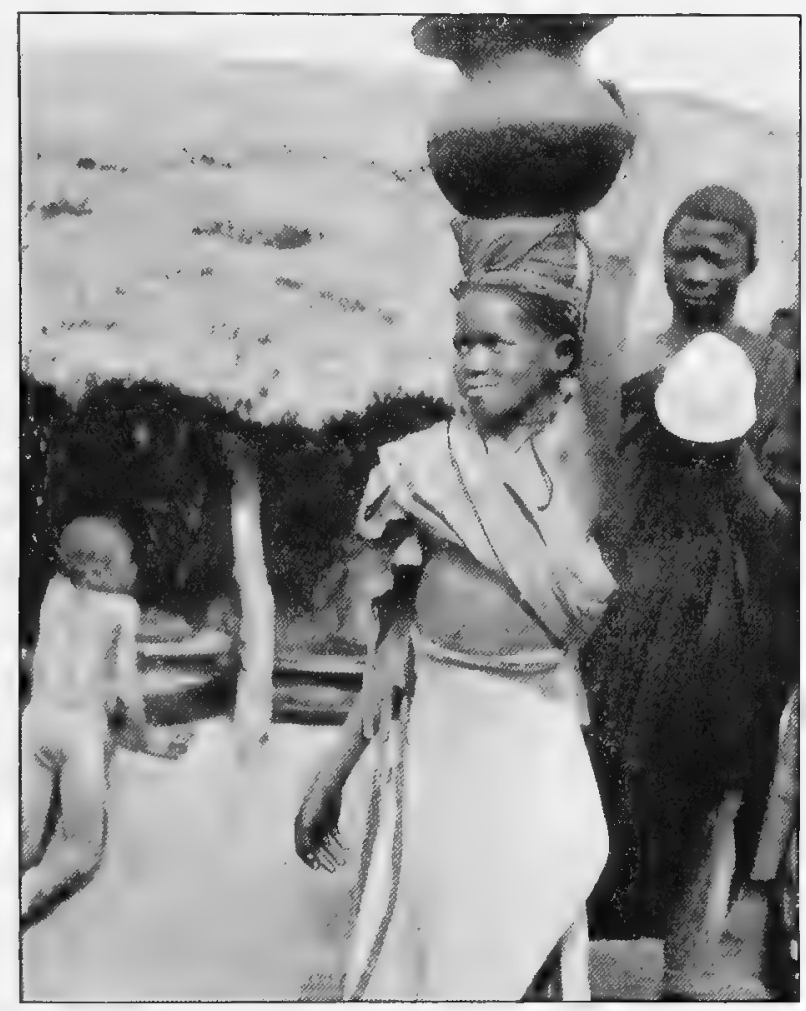

IN IBI MARKET

giraffe and buffalo, but these animals the natives told him would not come there again till the grass had started growing with the rains. He managed to secure a magnificent waterbuck with record horns of $29_{4}^{3}$ in. The kob in this part also carry remarkably fine horns, and it is not unusual to get them measuring 20 in. On this expedition Gosling did many long stalks after Senegal hartebeest, which were difficult to get a clear sight of owing to the thickness of the bush, 
and hard to approach as they were nearly always feeding in company with kob, who get restless and snort and stamp at the approach of danger, communicating their fear to their companions. Once, he crept to within a hundred yards of a large herd of hartebeest which he watched for an hour.

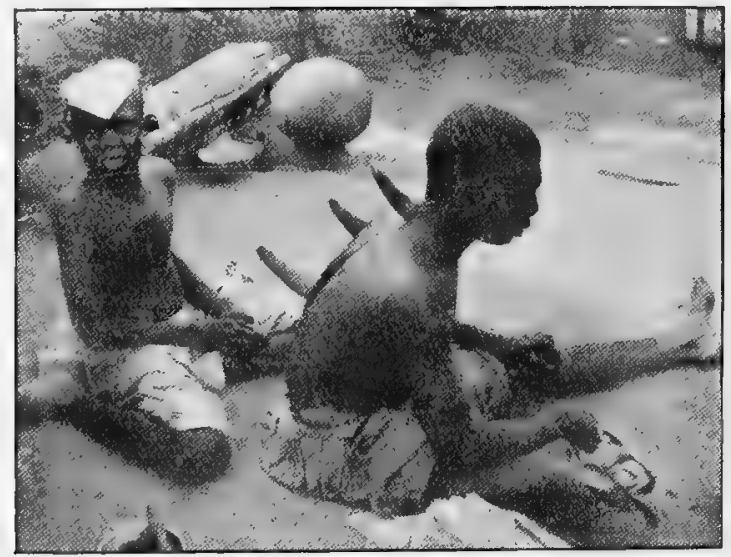

NATIVE METHOD OF CUPPING

They were in the open; some standing still and others lying down; and of all ages, ranging from fresh weaned calves to bucks with heavy horns. They were much worried by the flies and their big ears and long tails were continually on the move. Sometimes one would start and run fifty yards or so, driven by the sudden pain of a bite. On one occasion he saw two hartebeest feeding in the open in the middle of a herd of kob, through which he successfully crawled on hands and knees without starting them, and dropped one of the hartebeest at 200 yards as they were moving off. The satisfaction at this kill was somewhat spoiled, however, by his gun-boy's breaking the stock of his twelve-bore gun, using it to club the wounded animal, which the boy alleged had 
attacked him. That evening he returned to his camp very tired, and ate his dinner under difficulties owing to the clouds of moths and insects which swarmed round his lamp, darkening the flame. Presently an old man crept up and sitting on

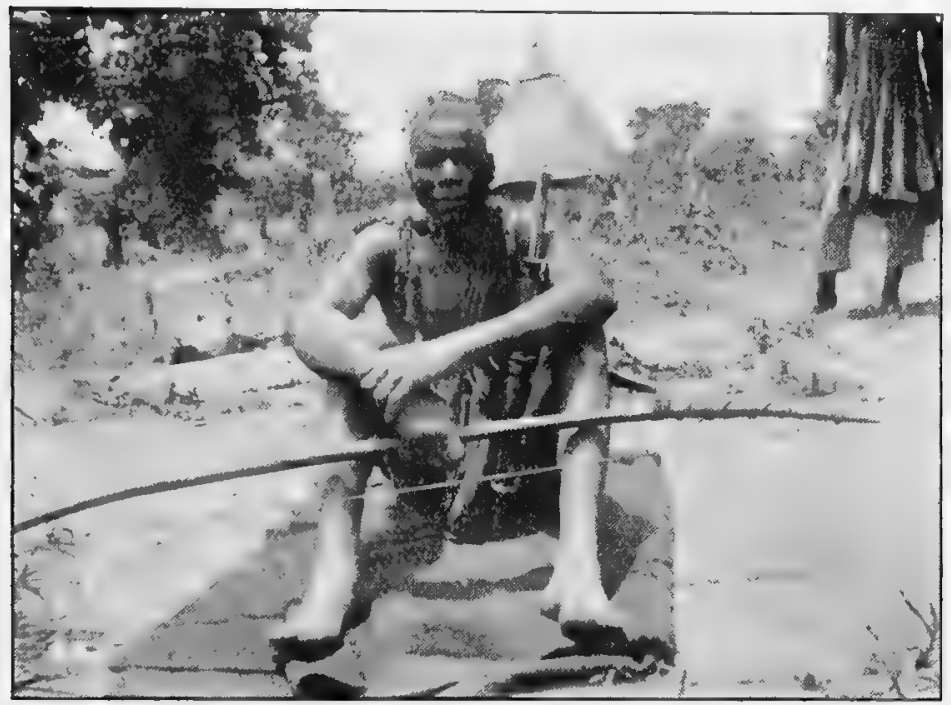

KING OF LAFAN GISSERI

the ground just within the ring of light, brought out from under his bernouse a little banjo, made of a gourd and stick with two strings, which he thrummed, producing notes of most sweet and musical tone. He was a wandering minstrel and had lived by the music of this same instrument for twenty years.

At Gisseri Gosling took an interesting photo of a native doctor cupping a patient for blood-letting. He describes the process as follows. "The skin was wetted and the ends (5 in. long) of five cow-horns with holes bored in their ends were applied. The doctor then sucked the ends and plugged the holes quickly with some cotton which he had 
in his mouth. Then, after a short while, when the pores had been opened, the horns were removed and incisions made with a small knife. The horns were then stuck on again and sucked as before. After a little they were taken off and found to contain a lot of thick blood that had been drawn

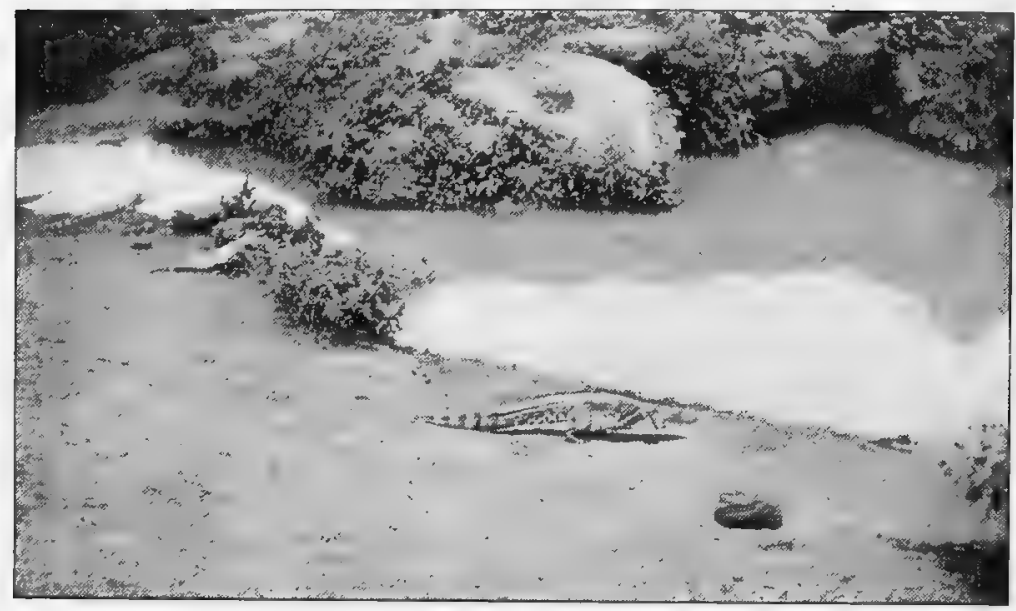

THE SACRED CROCODILE POOL

from the skin. The last operation was to rub the incisions with butter. This man was having his back done and did not seem to enjoy it."

At Wukari, some fifteen miles south of Ibi, where Gosling and my brother had occasion to go, hunting and collecting grain for the projected survey expedition, which would be passing through country where food was scarce, there is a little pool just outside the village, only about $20 \mathrm{ft}$. long and very deep, which the natives say springs from a subterranean river. It is the home of a number of crocodiles that have been there as long as the memory of man and are believed to have come up through the sources of the 
water. Two of them are $s \mathrm{ft}$. long. Here the natives come down and wash all among them on perfectly friendly terms. Wukari stands high and is consequently used as a health

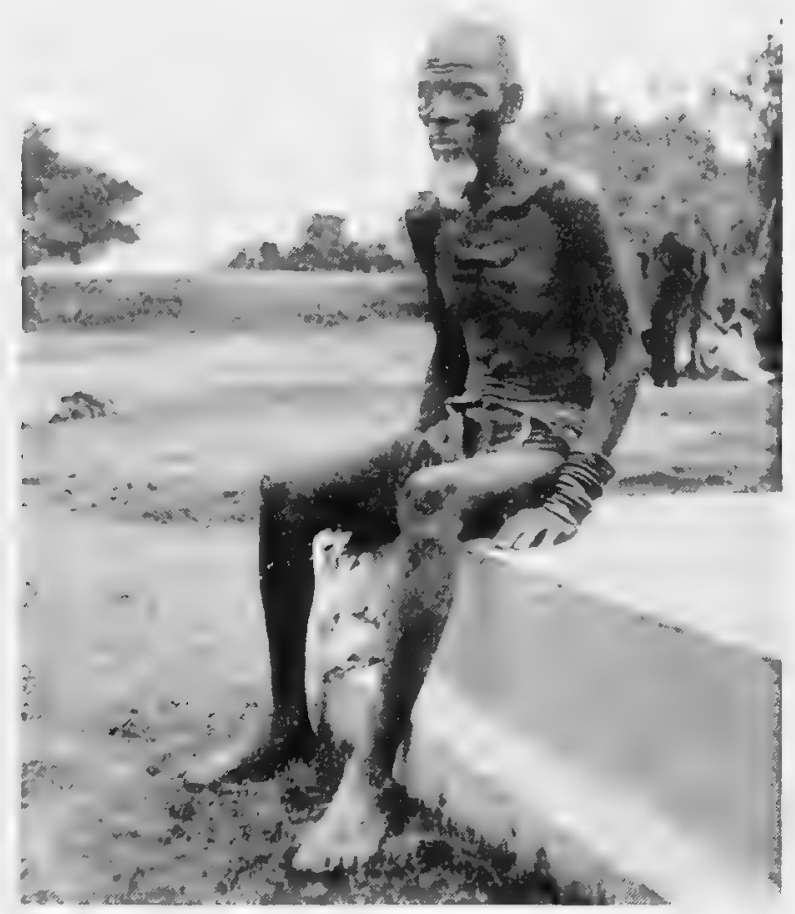

MONTOII, CANNIBAL CHIEF

resort for Ibi, which is an unhealthy, fever-stricken place. Horses are also sent up there to avoid the tetse-fly belt round Ibi in the wet season. We ourselves lost two in a very short time. The news of their deaths was broken to us by our horse-boys coming with long faces and bearing the tails of the unfortunate animals as a proof that they were dead and not misappropriated, for the native "boy" never expects to be believed without a proof in his hand. 
While we were at Ibi the old cannibal king of the Gurkawa was sent in as a prisoner, the result of a Government expe-

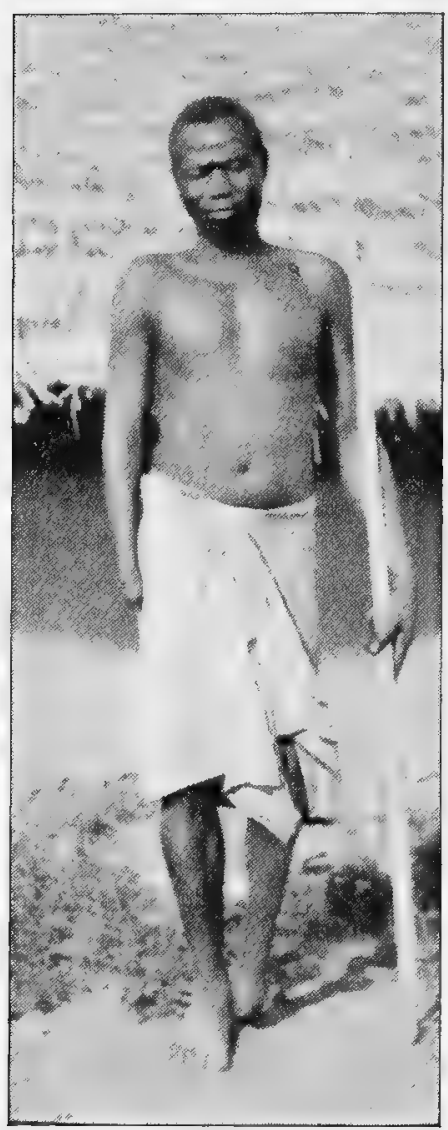

THE PENALTY FOR THIEVING dition from the post of Wasé against that tribe. In the $\mathrm{Ju}-\mathrm{Ju}$ house of his country five skulls of native traders were found, which had been picked clean by this old gentleman. My brother took photographs of him, an operation which caused him some alarm, for he had never had a camera levelled at him before.

One day in the Ibi market I saw the pitiful sight of a malefactor with his right hand and left foot cut off. He had suffered at the hands of the Emir of Bida for stealing in the days before the British occupation.

As our work in the future would necessitate our going off the beaten track into unsettled districts, I applied when at Lokoja to headquarters for an escort, which arrived at Ibi before we left. It consisted of two corporals and eighteen men, Yoruba and Hausa, of the West African Frontier Force.

At Ibi we spent many days of fruitless attempts to take 


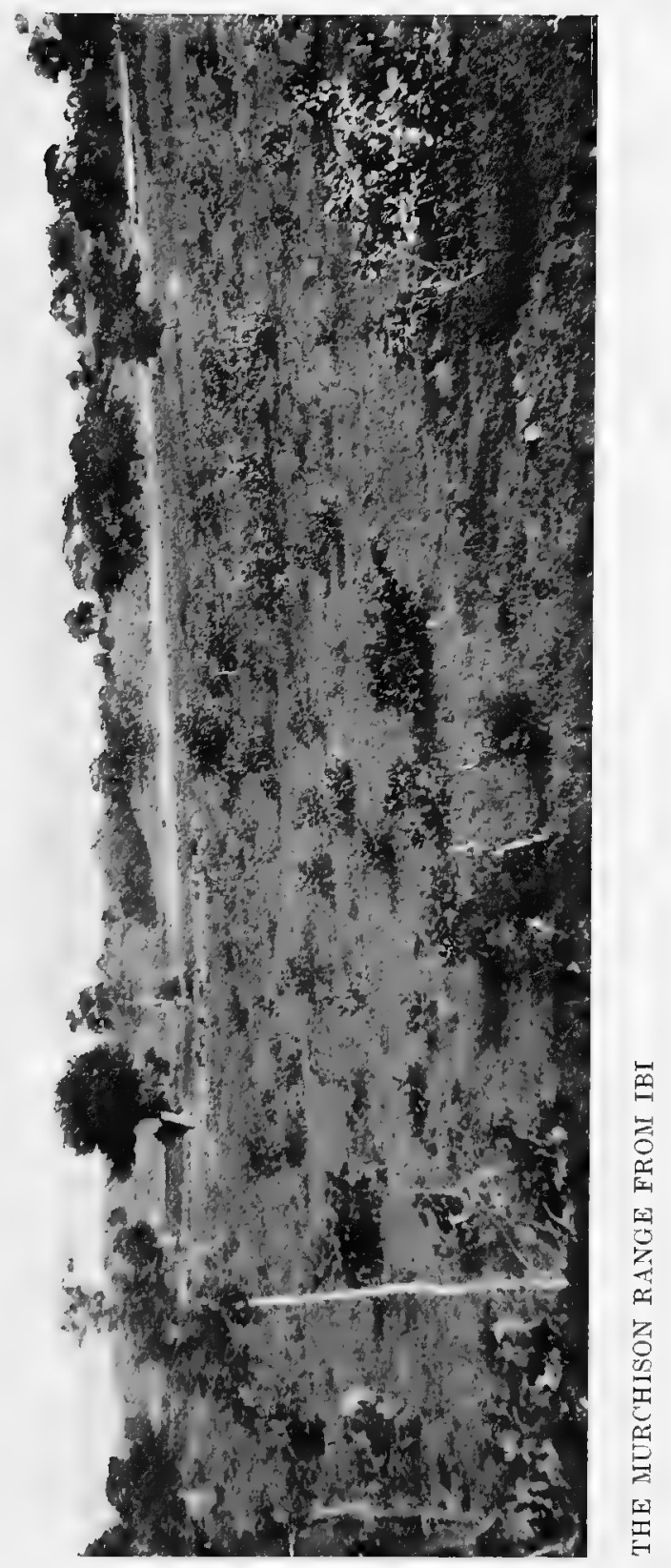



observations; nothing seemed to lie before us but a vast expanse of bush, with no point to the northward except the one ridge of Serikin Kudu, where my brother went on April 23 and put up a subtense of lights to which angles were taken. From his report it was clear that nothing could be done from that ridge, as before him lay only line after line of forestclad hills with no distinguishing point, and we began to fear that we should be compelled to give up all idea of connecting Ibi with the northern country, except by astronomical determinations, since a rigorous traverse would have taken far too long. However, one day after very heavy rain, to our great delight my brother reported the appearance in the distance of a dim outline, which we knew could be no other than that of the Murchison Range. I can imagine his great joy at the discovery after days of disappointment, which I think he expressed well when he said he then realised that the psalmist must have been a geographer who sang: "I will lift mine eyes to the hills, from whence cometh my help." 


\section{CHAPTER III}

\section{A LION HUNT}

OwING to the thickness of the bush on the Serikin Kudu ridge, we had found it impossible to take up points by day. Accordingly, on May 4, my brother went the six miles out there in order to light beacons which Talbot might work on from Ibi. As there was nothing for me to do in quarters, I followed on on the 5th, with the idea of lending assistance, should it be required, and hunting by the way.

The road led through bush forest of Senegambian character and broad stretches of elephant grass. About two miles out of Ibi it crossed the River Simanka twice, for the stream was very serpentine. It is a pretty river, well wooded on both banks, which are high at the bends and afford thickly tenanted nesting colonies for the red-breasted beeeater (merops nubicus). At the time of year the water was very low, and as its course and the direction of my journey lay for some four miles together, I travelled the distance along the river-bed. I arrived at the small village which gives the ridge its name at about six o'clock in the evening, and, learning from the natives the whereabouts of my brother, went out and found him about one and a half miles to the east cutting the bush and lighting huge fires on the highest point of the ridge and climbing high trees in the hopes of catching sight of an answering beacon from Talbot. But 
though the fires were fed for two hours they met with no responding signals and, believing that we had failed to get in touch, we returned crestfallen to the village where we camped the night.

Serikin Kudu is a village entirely made by a settlement of slaves that have escaped from the King of Wasé. They have no chief, and I found the same rule, or rather want of rule, obtaining in a village of runaway slaves on the River Yei. The fact of the two similar instances struck me as interesting. Evidently slaves, representing the class on which the burden of a despotic government falls most heavily, on being freed, instinctively turn to socialism for the remedy of their political evils.

Next day my brother returned to Ibi to make other plans with Talbot, but fortunately found that he had seen our signals although we were unable to see his answering fires. I remained two days on the ridge to work the bush for birds. Here I found the distribution identical with the Senegambian fauna.

On the second day Gosling passed through, returning from his hunting expedition at Lafan Gisseri. We had mid-day "chop" together, and then he continued his journey back to Ibi.

At this time the natives talked much to me concerning the misdeeds of some man-eating lions. They were a male and female, and had chosen the Yelua-Loko road for their hunting-ground, which they worked with such success that the caravan traffic had been completely paralysed. Quite recently in an attack they made on a caravan, encamped at Tapkin Dorina (the pool of the hippopotami) they had 
carried off a man and woman, and in another they managed to secure two boys. Accordingly, I determined to go against them and started next day with two of my Hausa escort and fourteen carriers. José coming from Ibi caught us up

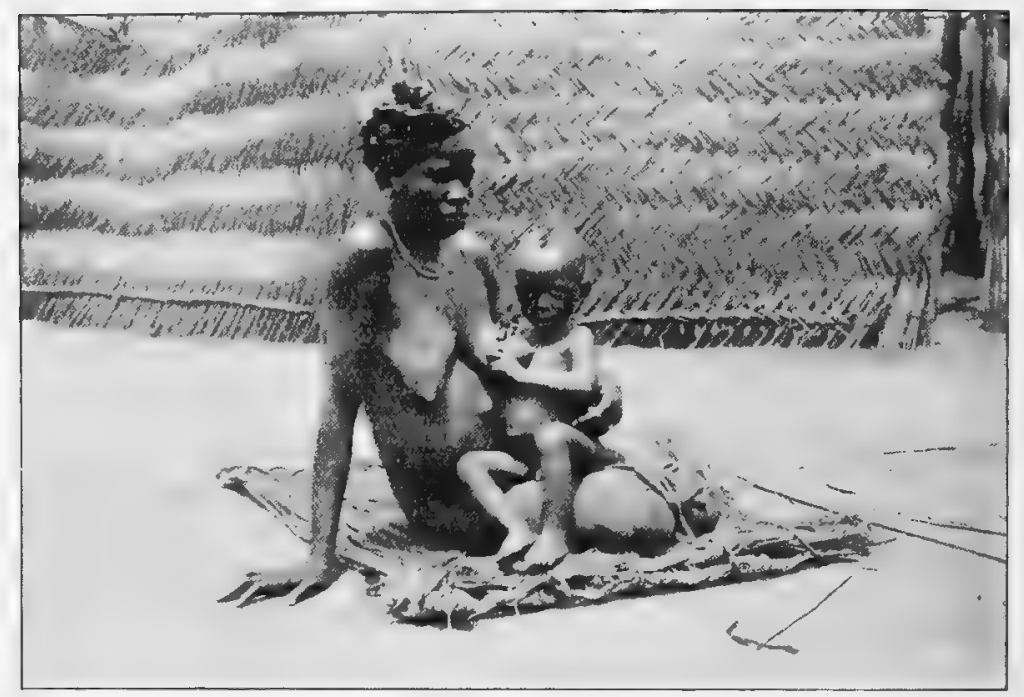

WIFE OF THE KING OF LAFAN GISSERI

early in the day. Though I had my horse with me, I did not ride very much, for I was busy collecting birds on the march.

The village of Mutumbiu (two men), a small collection of huts, was reached about mid-day. Here we heard more lion stories from the old chief, who fed us liberally and provided us with a comfortable hut for the night before putting us on our road the next day.

Before leaving, we gave his wife an empty whisky bottle, which caused her unbounded delight, and a fine kob which José had shot was presented to the village.

From Mutumbiu we followed a path through the bush 
for about seven miles and then came out into an open plain. The land lay very low and showed evidence of being covered with water in the rainy season by the huge gaping fissures and deep spoor of elephants, now baked permanently hard by the sun. Here there were great numbers of hartebeest, which fed over the plain like deer in a park. As we wanted meat for the carriers I decided to stop, and José shot a buck while I brought down a Senegal hartebeest.

I had come to the conclusion that it would be unwise to go after the lions with the ordinary Mauser bullets, which were all the ammunition we had with us, so I sent José back to Ibi to fetch some soft-nosed cartridges. As the distance there and back was about forty miles I pitched camp on the plain that night in order not to leave José too far behind. Besides, the carriers had plenty to occupy themselves with over the game, and I looked forward to a long afternoon's bird-collecting. Next day we moved on and a few hours' march brought us into the lion country in the neighbourhood of Tapkin Dorina. We were then following the caravan road through pretty country; on either hand thick trees and bush, broken up into clumps by green sward, which was cropped to a smoothness like down-grass by the herds of game. Here and there were thick fringed pools and high elephant grass beyond. I was musing on the beauty of the scenery and thinking what a capital lion country it appeared to be, when suddenly my orderly called out "zachi " (lions !) And following the direction in which he was pointing, there against the low bush about 150 vards away on my left, I beheld two lions, a male and female, steadily regarding us with quiet gaze. I niust say I was astonished to find them 
with so little trouble and without even going off the road. There they were with heads close together, cheek by jowl, making such a pretty picture, that, when Moussa begged me to shoot and I, remembering that I had not the right sort of bullet, refrained, it was with regret considerably lessened. Besides, I did not want to make a mess of it and perhaps lose them altogether. Presently a little farther on the lions crossed the road behind, and appeared in the bush to my right. It was a strange sight to see the numerous kob deer, heedless of danger, feeding on the plain just a little way off. Then with an au revoir to the lions, we continued our march, and two miles brought us to Tapkin Dorina, where we pitched our camp.

Tapkin Dorina is a lake of about half a mile in length and a quarter of a mile in width. It lies in an open plain to the right of the road that has not very long come out of the bush. Its shores are quite bare of vegetation and its waters are thick with crocodiles. It is a favourite halting-place for the thirsty caravans plying between Yelloa and Ibi, hence the man-eating lions also found it a convenient spot for refreshing themselves.

I selected the shelter of a huge solitary tree not far from the lake side for the camp.

I had felt very sick and weary all the day, finding it difficult at times to keep on the move. Fever had taken hold of me at my bad hour, three o'clock in the afternoon, and now after sundown my symptoms grew worse and I vomited a great deal. So I turned in early, but first of all sent two of my men back with a letter to José, to warn him not to travel at night through the part where the lions were. Also, as 
the tetse-fly was very bad about here, I made an attempt to send my boy back with my horse with instructions to leave him in the charge of the old chief at Mutumbiu.

That afternoon, on the call of "lions!" I had drawn rein on my horse suddenly and it was a most strange sight to see the poor beast, on becoming aware of the nearness of danger, instantly grow rigid and tremble in every limb. Nor whip nor spur could move him and I had to get off and, with Moussa's help, almost lift him along some yards before he would start going again. And now again, when the horse reached the same spot on the road where he had first encountered the lions, nothing would induce him to pass it, and, turning suddenly, he bolted straight back into camp. So after that he had to take his chances with the flies, except for the protection of a fire, which I caused to be lit near him in the daytime. I had several lamps with me which we lit and hung round camp at night as a warning of danger to the lions, and the men made a large fire round which they slept. At intervals through the night I was awakened by the short, deep cry of the lion-a cry that has a most strange and weird effect upon the sleeper within range of its sound. No matter at what distance it is uttered, or how tired, or how secure from attack the sleeper may feel, its deep vibrations will penetrate to the very centre of the senses and he will start up on the instant wide awake and all aware of the nature of the call. Though I was feeling so ill and worn out with the fever which had hold of me that I would have said that I could lie down in a menagerie so long as I was permitted to sleep, yet this night, every time the lions uttered their unearthly cry, I was startled wide awake, and every 
time I heard a groan go shuddering through the circle round the fire, and a man would jump up and rake the embers to a blaze.

Next morning I was surprised at being called by José, who had not heeded the warning of my letter but come straight through, arriving in camp without mishap at 3 A.M. I was now feeling so shaky that I decided to take a day's rest, but, anxious to have news of the lions, I told José, who needed no encouragement, that he might conduct an armed reconnaissance in their direction. Accordingly, José set out with two men to hunt for them in their haunt of the previous day, nor did he have to search for long before finding them near a pool on the left of the Ibi road. They were standing together on an ant-hill in the open, and José, going forward to within one hundred yards, took aim at the male just behind the ear and fired. The lion dropped like a stone and the lioness sprang into the tall grass where she turned and stood at gaze. José then advanced to inspect his prize when suddenly he saw it make a move as though not quite dead, so he thought it best to give the animal a little more time and waited at a respectful distance. But to his great surprise, after a few minutes the lion got up and trotted off to his mate in the grass where they both disappeared. José then went and examined the ground where he had fallen and found some broken teeth, which proved that the bullet had struck him in the jaw. Thinking that the wound must prove fatal and that the body would be found lying dead a little way in the grass, José determined to follow. But the tracks led him further and further and always there were the two, where the animals had crouched and flattened the grass, 
that of the wounded lion on the right, sprinkled with blood, and that of the lioness, supporting him close at his side. It is always a dangerous thing to follow up a wounded animal right into the thick cover of his retreat. In this case there would be the two infuriated lions, which might at any moment have been found, turning prepared to spring. José at last realised the risk of it, so gave up the chase and returned to camp.

I was naturally rather put out that he had not been able to keep his finger off the trigger, and still more so on realising that his unsuccessful shot had perhaps spoilt my chance of securing a lion, so, anxious to lose no time in getting on to the tracks of the wounded animal, next morning, though still feeling very ill, I got up to go after it. We knew that the lions were still in our near neighbourhood by their cries that we heard continually throughout the night, so we went to the place where José had given up the chase the day before and soon found the tracks again where the blood, in spite of a very heavy dew, was still plainly visible. I pressed on through the tall grass, with José to my right and Moussa a little behind. Then came four carriers, bringing up the rear. The fatigue of toiling some distance through the jungle in my weakened state soon got too much for me, and, feeling very sick, I found it all I could do to keep going, much less support the weight of my rifle, so I gave it to Moussa to carry.

As I was almost giving in there appeared in the distance a break in the monotony of the grass, where a slight depression in the ground, marked by a cluster of trees, struck me as being a likely refuge of the lions, so I struggled on, resolved 
however, not to try any further than this point. Arrived there, we found that it was the dried-up, sandy bed of a little stream, that followed its course into the lake of Tapkin Dorina. I came out of the tall grass and went down into the donga and was just peering up the gorge, when suddenly I was aware of a large mass of live yellow, crouching under the screen of branches of an overhanging bush. I instinctively turned and threw out my hand for my rifle, but Moussa and the other "boys" were conducting a lively stampede into the grass behind. At that instant the yellow mass sprang with a roar like a storm over my head when José, firmly standing his ground, with great presence of mind sent a lucky shot whizzing close over the lion. Coming so soon upon the unpleasant memory of his encounter with a bullet the day before, though the shot narrowly missed him, the noise was enough to make him turn in the air, and he alighted on the ground within about three yards of my left and dashed into the long grass. The sudden shock of this adventure had the effect of bracing me up, and I forgot my weakness for a while in my keenness to continue the pursuit. In the meanwhile the "boys," whom José's shouts had assured of their master's safety, one by one returned with bravery restored, to be dealt with by José in chosen terms. They were now extraordinarily anxious to assist in the further pursuit, well knowing that a lion, twice fired at and wounded would require all the additional help of their skill as hunters to be persuaded to stand and face a rifle for the second time that day.

We then went up the bed of the stream, and not far beyond the spot where I had first seen the crouching lions, 
we came upon their lair. It was a cosy little dwelling-place, covered and concealed by two thick, low thorn bushes,

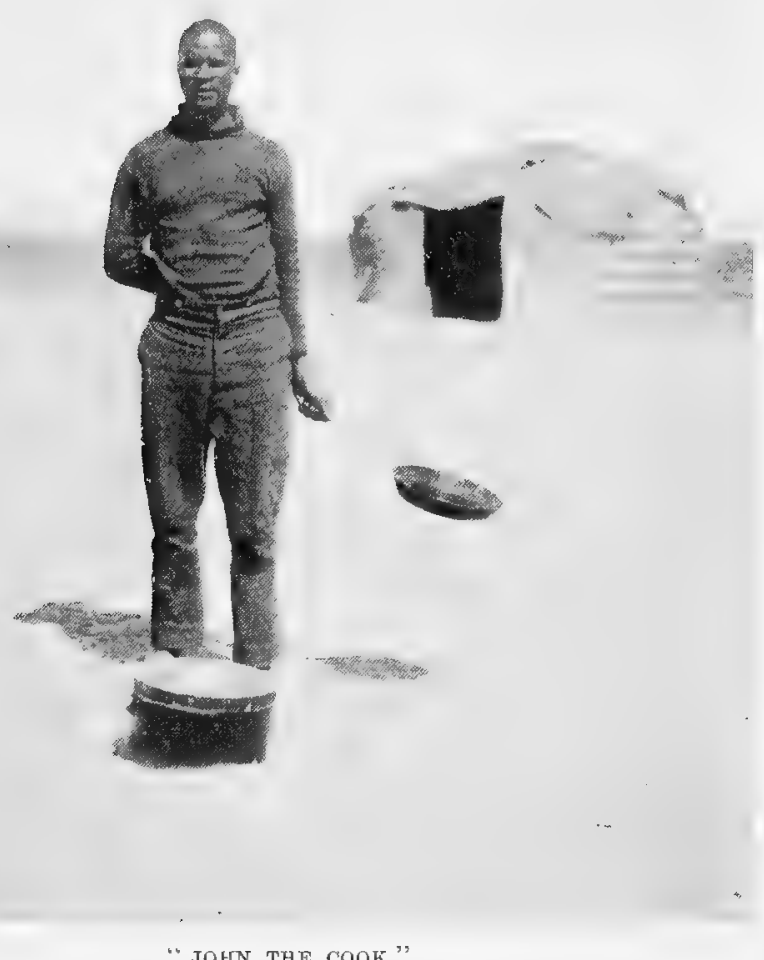

WHO HAS ANNOUNCED A FORTHCOMING WORK ON THE EXPEDITION

that met arching overhead. Creeping in at the entrance on hands and knees, for the branches hung very low, one could see their "forms" in the bed of dried leaves and grass which was decorated with dry hones. The sight of this pleasant abode made its owner a still more interesting object in our eyes and we were all the more anxious to improve our acquaintance with him, so, accordingly, we again hunted 
the long grass, making a circuit that took in several likely spots and eventually brought us back again to the donga at a point just above the lake without our having met with any further success. With the sense of failure my feelings of sickness returned and all were leg weary by now, so we were not sorry when we had covered the half-mile that brought us into camp. Here we found the "boys," eagerly awaiting our return, having already sauced the lion chops in their imagination, and doubtless gambled away its heart, for they had heard the single shot which the native knows is a sign of promise. But, once more they were destined to disappointment. It was now noon and John the cook greeted me grandly, conscious that he had spent his best efforts on a dish of buck's liver, garnished with mashed yams, and hoping that I had brought home with me, if not the lion, at least an appetite begot of the lion, that would do justice to his skill. When I realised what the delights of such a pleasant meal, with tea and a pipe to follow, would have been after all the exertion and excitement of the long morning had I been in my normal health, I felt very sorry for myself and, to John's dismay, could only take a cup of bovril and afterwards tumble to bed to try and sleep for years.

Next morning, though feeling no better, the cry of the lion about a mile from camp pulled me out of bed to go after it, and we set out about six o'clock in the direction whence it came down the Serikin Kudu road. As the cries grew louder and told us we were getting near, Moussa got rather jumpy and mistook a gentle kob, that was standing a little way off in the bush quietly regarding us, for the king of 
beasts. Presently we heard the lion returning on his path, so stood still and waited. In a few minutes he came into sight about fifty yards on the left, trotting briskly along. I took my first shot at him and missed. My failure annoyed me very much, and I tried to find an excuse in the very weak and shaky state I was in at the time. José then fired, hitting the animal in the shoulder but failing to bring him down. The shot, however, made him turn off into the long grass and we traced his tracks with our gaze by the shaking of the grass tops for about forty yards. We then followed in the direction as quickly as possible, but the going was rendered difficult and we could hardly keep our feet for the unevenness of the ground, which had been broken up into hard hillocks and deep holes by the tracks of elephants when the rains had made the place a swamp.

Soon we realised we were upon our quarry when close ahead we heard a low angry growl and a great commotion in the grass as of a heavy animal struggling to get upon his feet. Then suddenly we saw his tail stand up erect above the grass and the moment after his great head and shoulders appeared. On he came, growling and struggling and pushing himself along by great strokes of his hind legs, for the poor beast was unable to spring, owing to the wound in his shoulder. At ten yards distance he paused, glaring, and made one great effort to spring. I fired and hit him in the forehead and he fell dead instantly. There was now great excitement among the "boys" and, after making quite sure that the lion was dead, they pressed round and feasted their eyes on the carcase. Then one ran off to be first with the good news in camp, while others went into the bush to cut stout sticks 
for bearing poles. On these the lion was slung and six men carried him into camp. We were met outside by the rest of the "boys" and with them came a big Hausa trader, who,

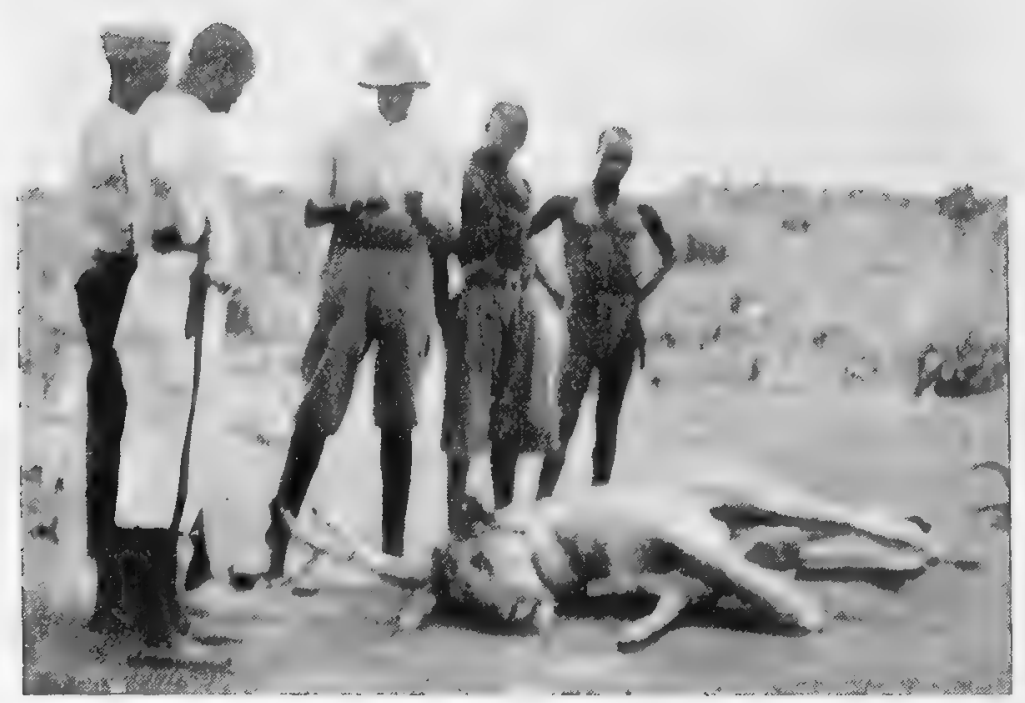

THE LION

hearing that a white man was hunting the lions, had ventured to take the road with his caravan. He was overjoyed at the sight of the dead lion and thanked me with a great show of enthusiasm, telling me that its death would open a road that had been closed to trade for years. Afterwards he showed me the burial-place of the fragments that remained of two men, who had fallen victims to the lion. Strangely enough, without knowing it, we had pitched our camp almost on the site. The trader's camp was just on the other side of the big 
tree, and there were collected his wives and followers with cattle, donkeys, and goats.

José and two of the boys, whom he had trained to help him, got quickly to work, skinning the lion. After this operation was finished, all the "boys," who had meanwhile been impatiently sharpening their knives, made a great rush for the carcase and a fierce battle ensued for the possession of the heart, which natives all believe will bestow the courage of the lion on the man who eats it. John the cook, no doubt owing to his expert use of the knife and a deeper knowledge of animal anatomy that he had gleaned in the pursuit of his profession, was easily victor, securing all save a little corner of the heart. But, conscious that his own courage needed no stiffening, he nobly withstood the temptation of surfeiting himself on the heroic food, but cunningly dried the heart and, cherishing it all through the journey to the Nile, took it home with him to nourish and make stout the heart of his little son.

Afterwards the meat was cut up and divided among the "boys" and John was busy ripping off the fat to make into cooking grease. I, too, felt that I ought to pay some sort of respect to the remains, so ordered lion chops for dinner. But I did not think that they had turned out a very great success, for he who proved such a tough customer in life, in death did not belie his reputation.

That night there were extra fires in the "boys" camp and much eating and merriment that continued until a late hour, and when finally the "boys" fell asleep around the fires, the embers did not leap up into flames at 
intervals as on former nights in answer to the cry of the lion.

Next morning we awoke to find the day drenched in torrential rains, which was unfortunate for the drying of

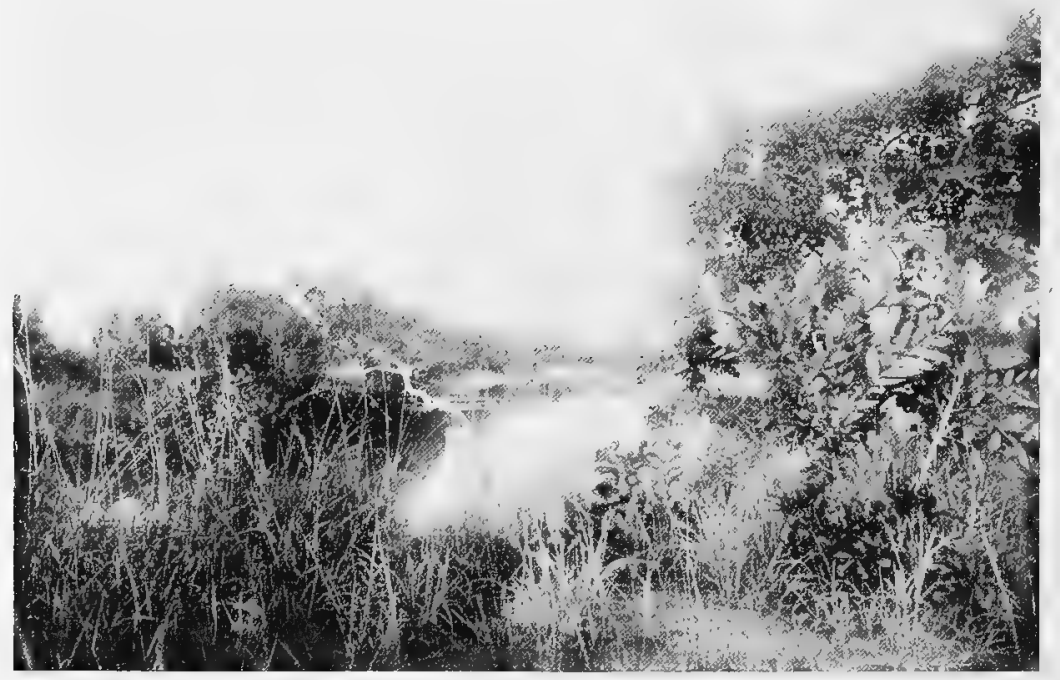

RIVER SIMANKA

the lion's skin, the hair of which had already begun to slip in places. I was kept a prisoner in my tent until about eleven o'clock, when the skies rolled up and gave forth intervals of sun. So I decided to strike camp and make my way back to Mutumbiu. To give the lion's skin every chance of drying, a wooden frame was made, on which the skin was stretched and carried on the heads of two of the "boys," so that it might receive all assistance from the sun. I went ahead of the "boys" as was my usual custom, in order to make détours into the bush for birds, returning to pick up the column along the road. 
By three o'clock I felt I had done quite enough, so decided to pitch camp for the night in the bush. Again all that night there were very heavy rains which cleared by six o'clock in the morning, when we once more resumed the march. A mile from Mutumbiu we crossed the River Simanka which we found much swollen by the rains, so that I was wet up to the waist as I rode across. The chilly water had the effect of bringing on an ague fit and my sickness returned, more severe than before. I had just strength enough to struggle on into Mutumbiu and then I collapsed. José had my bed made in the house of the kind old chief, whom we have met before, and here he nursed me all that night and the next day till the following midnight, when the alarming symptoms of blackwater fever appeared. Up to then I had been treating myself for ordinary fever with large doses of quinine, but now that was useless, and, in consequence of the serious nature of my illness, José left me in charge of John the cook, and rode off to Ibi next morning posthaste for a doctor. Unfortunately the doctor had been called away to Wasé, so José, after leaving word of my plight, rode back the same night with what medicine and invalid food he could find. He arrived the next morning to find that the crisis had passed, though I was not yet out of the wood, and still in a very prostrate condition. I regard this as a very splendid performance on José's part. For, it must be remembered that he had been two nights and a day without sleep, in constant attendance, before he accomplished without a pause the ride to Ibi and back, a distance of fifty miles, with a river 800 yards wide to cross and recross. The next day Gosling arrived having heard the news that I was ill on his return to 
Ibi from a hunting expedition soon after José had left there. It was now determined to carry me back to Ibi, jmprovising a hammock for the purpose out of my tent slung on two long poles. The journey took two days, or rather nights with a day's rest at Serikin Kudu in between, for we were obliged to travel by night to avoid the heat. By this time weakness had rendered me too torpid to feel the discomfort of the journey, much less to take note of incidents by the way, but I was told afterward that the natives of the villages we passed showed very kind solicitude for my condition, always first inquiring if I had been wounded by wild beasts; nor did their interest slacken when they heard I was the victim of a more invisible foe. I was also told that I was busy shooting lions the whole way. The day after our arrival at Ibi Dr. Ellis came in, having started on hearing of my illness and accomplishing the journey by forced marches. Under his excellent care I made a rapid recovery, and as soon as convalescent went down to Lokoja for a change. There I stayed a fortnight before starting on my trip to Bauchi. With commendable caution Dr. Ellis ordered me to return to England. I know his innate kindness and he will be glad to hear that I have not since paid the price of my disobedience.

While at Ibi, I was able to superintend the transport of the Expedition, procuring an escort of sixteen Hausa soldiers and sixty carriers, and collecting stores to last six weeks, with which my brother left for Wasé where he was to rejoin Talbot and conduct the survey into the Kerri-Kerri country. Also there were the boats to start, under the conduct of José, on their journey to Asharka on the 
Gongola, which place we had determined to make our base at the conclusion of the work in Nigeria. This was the first trip of the boats with their full complement of stores and complete crews. Each boat was manned by six Nupe polers, who are the watermen of the River Benue. They were a useful set of men, smart at their work and of splendid physique. The captain of the crews, called Audelai, was a big fellow of Herculean build, the champion poler of the Benue.

Four large native canoes, carrying the rest of the stores formed the tail of the flotilla, which, as it glided down the river headed by the graceful white boats with white sails spread, suggested to my mind the image of a monster bird, tamed to the pursuit of some romantic quest in a far fairyland. Before the little fleet set sail I made an inspection and found that the canoes were carrying more ballast than I had bargained for. Hidden under mats in the bottoms were the wives, whom the soldiers had hurriedly married the day before and who, laden with evidence of their domestic virtues in the shape of calabashes and cookingpans, were looking forward to a happy honeymoon upon the river. I was sorry to disturb their composure, but it was against orders, so out they had to come, all save the consort of Audelai, the captain, who was a privileged person. This little diversion caused a good deal of amusement among the crowd who had collected to witness the departure, and the laughter bubbled over at sight of the lifting of one dusky bride whose noble proportions suggested her worthiness to sail in a boat of her own. After this short delay all was quite ready for a start. The naked polers leaned upon their poles 
and two men held the ropes in readiness to hoist the sails. At the word of command a sudden shining ripple ran down the muscles of the backs as they bent to the poles. Then

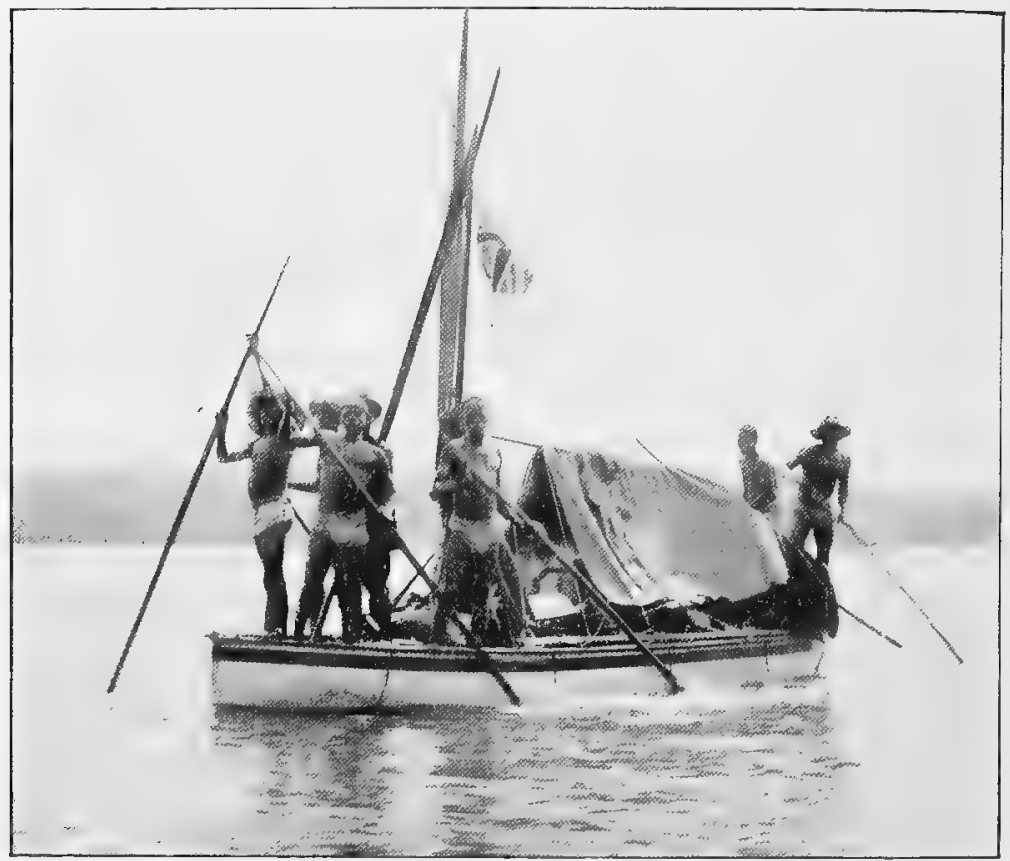

"THEN OUT FLEW THE IITTLE UNION JACKS"

cheers broke out from the people lining the banks, answered by the swifter plunges of the boats which soon gained the middle stream; then out flew the little Union Jacks and up went the white sails to the sun. As they swelled to the freer wind, I felt my heart swell too with pride at the brave sight, and my imagination went out before them striving to fill in the chart of all their eventful voyage to the Nile, but it grew tired of visionary, swift, smooth rivers and a bright blue inland sea and it soon returned to me. Now as I write it seems 
to me that this was as well, else my thoughts had been darkened by the shadows of troubles to come, that always lie deeper across the mind, and my ears would have been filled with echoes of struck rocks and the noise of water pouring in, the roar of rapids and the cries of drowning men. 


\section{CHAPTER IV}

WITH THE SURVEY PARTY TO THE MURCHISON RANGE (Written by .1/r. P. A. Talbot)

[I Am indebted to Mr. P. A. Talbot for the record in the following three chapters of the survey work from Ibi to Maifoni.]

The Survey party consisted of its leader, Captain Claud Alexander, myself, about seventy carriers and an escort of fifteen soldiers belonging to the 2nd Btn. Northern Nigerian Regiment. We had with us two theodolites, Cary's 6 in., and Troughton and Simms' 5 in. micrometers, two boilingpoint thermometers, three aneroids, a plane-table, a maximum and minimum thermometer, and a 3 -in. astronomical telescope for occultations, and were in general very well equipped for the projected work.

On May 3 the party bade good-bye to Boyd Alexander. Gosling had already gone off hunting to Lafan Gisseri in the neighbourhood of Ibi.

After the carriers and impedimenta had been ferried across, a start was made from the further bank of the Benue, which is here about 1000 yards wide. For the first mile or two the bush was very thick, and for part of the way we marched along one of the dry channel-beds of the River Simanka. After the glare at Ibi, it was very pleasant to go through the woods which lay on either side of our route. 
These were full of wild life in general, and monkeys in particular. Perhaps the most pleasant thing of all was the thought that we had now, at last, started on the work we had come to do.

Our order of march was practically always the same. Alexander went on ahead with the guide, an interpreter, and part of the escort; next came the carriers with another soldier or two, and I brought up the rear with the head-men and the rest.

Until the Murchison Range was reached, both of us sketched the route, he on a cavalry sketch-board, and I with a prismatic compass. From that point, when we were together, only Alexander made the route sketches, as his were so excellent that it would have been mere waste of time for any one else to do any while he was by. It is a wonder to me how, notwithstanding the jolting of his horse, he could produce maps of such marvellous clearness and beauty as were those which were brought home. After a very little time he found that he could do these without ever stopping his horse, and, after the first month, never had to retouch them.

After we had left the valley of the river, the country grew more open, and assumed for the most part the aspect which it wore for the greater part of our journey. This was much like an English park, except that the grass was higher and coarser, and a good deal of scrub was met with at times.

About mid-day we arrived at the little village of Serikin Kudu, which is inhabited by the descendants of slaves who had escaped from the King of Wasé. Here our tents were put up, and we determined to stay, as we had resolved to make only short marches on the first few days until the 
carriers had shaken together. Afterwards, the usual duration of the march was about five hours, and the rate two and a half miles an hour, including the ten minutes' rest which they generally had after each hour's march.

The ordinary procedure on arriving at a village was as follows: If the chief was not there to meet us, we sent for him, or in case of his absence for the next head-man. After greeting him, and having a little friendly conversation, in which we made a point of telling him to let us know at once if any member of the party tried to steal, or misbehave himself-we told him the number of our carriers, and asked him to bring food for them as soon as he could. The food which generally consisted of millet or guinea-corn, and sometimes yams, seldom arrived till the evening, as most of the towns which we visited had little more this year than they needed for themselves. The chief of the town was always liberally paid before our departure and thanked for his hospitality. For this reason we seldom had much difficulty in getting food wherever it was to be had.

Next day we left for Serikin Warri, and on our way met several Ankwe, to which tribe most of the people between Ibi and Yelua belong. They are usually tall and slim, and of very mixed race. Each man was carrying his three long spears, the points of which are held downwards enclosed in a sort of leather sheath, much the shape of an elongated bell. When spears are protected in this way it generally means that they are poisoned.

Serikin Warri is a rather large village, enclosed in a big stockade, and lies on the eastern bank of the River Simanka, which we had to cross and recross next day, owing to its 
winding character. Where we crossed, the water was generally very shallow, though deep pools lay between. The whole river, in fact, looked like a series of long narrow lakes, though in the rainy season, the water rises to the top of the banks, which are $20 \mathrm{ft}$. high, and forms a rushing torrent varying from 30 to $90 \mathrm{ft}$. in width, very difficult to cross.

After three hours' march we arrived at the large stockaded village of Lakushi, where we had not meant to make a halt, but just outside, we came upon such a clear view of the Murchison Range about forty miles off, that we determined to stop there and try to connect it. We identified the principal peak which we had observed at Ibi, and took angles to the chief points. Unfortunately it came on to rain, so we could get no azimuths or latitudes.

On May 6, we did a five hours' march to Agikumai, which is a very clean town enclosed in a stockade and trench. All the villages in this part of the country are stockaded with ditches, and the huts with their compounds are hidden and scattered in plantations of millet.

It was at this place we saw a freshly killed lion and the slayer, the deed having been done by a poisoned arrow. The animal was said not to have moved after being shot. The skin was pegged out to dry, and a bit from the forehead was removed to mix with other poison to bring the sportsman luck.

Round here the game is exceptionally good. We saw great herds of kob and Senegal hartebeest. With care it was possible to get near enough to the herd to watch every movement. The kob are especially graceful, and even the 
queer lumbering gait of the Senegal hartebeest has its fascination.

While staying here, I heard one of the soldiers playing a musical instrument which the Hausas call a gilau. This is a stringed instrument made of about twenty reeds bound together at each end in the form of a tiny raft. On both upper and lower surfaces, at about an inch from the ends, strips of the reeds have been loosened and raised from the stems, from which they are separated by two transverse reeds. Each of the five tones is composed of three strings, bound round in the middle by grass blades. The body of the instrument is covered by a neat bit of basket-work made of the thin strips of reed already described, interlaced with broad grass blades, and contains some hard seeds or small stones, which rattle softly with the movement of the instrument. The tone is liquid and beautiful, and in the hands of a skilful player the sound of the little seeds can be made to imitate the patter of falling rain-drops, the rustle of leaves or the ripple of water.

We were fortunate in having a beautiful clear starry night for observations, and next morning started at 6.30, on a five hours' march to the walled town of Yelua. It is a straggling place, half to three-quarters of a mile from wall to wall, and crops are grown inside between the various compounds. From this town we could get a beautiful view of the Range, which was only about twenty miles off as the crow flies. We took angles to the principal points in hopes of being able to observe back to Yelua. Unfortunately, a heavy storm came on and put a stop to further observations. While here we persuaded the king to look through the 
telescope of the theodolite at the mountains. He professed to be enchanted with the view, but as it was impossible to induce him to put his eye nearer than 6 in., such a palpable

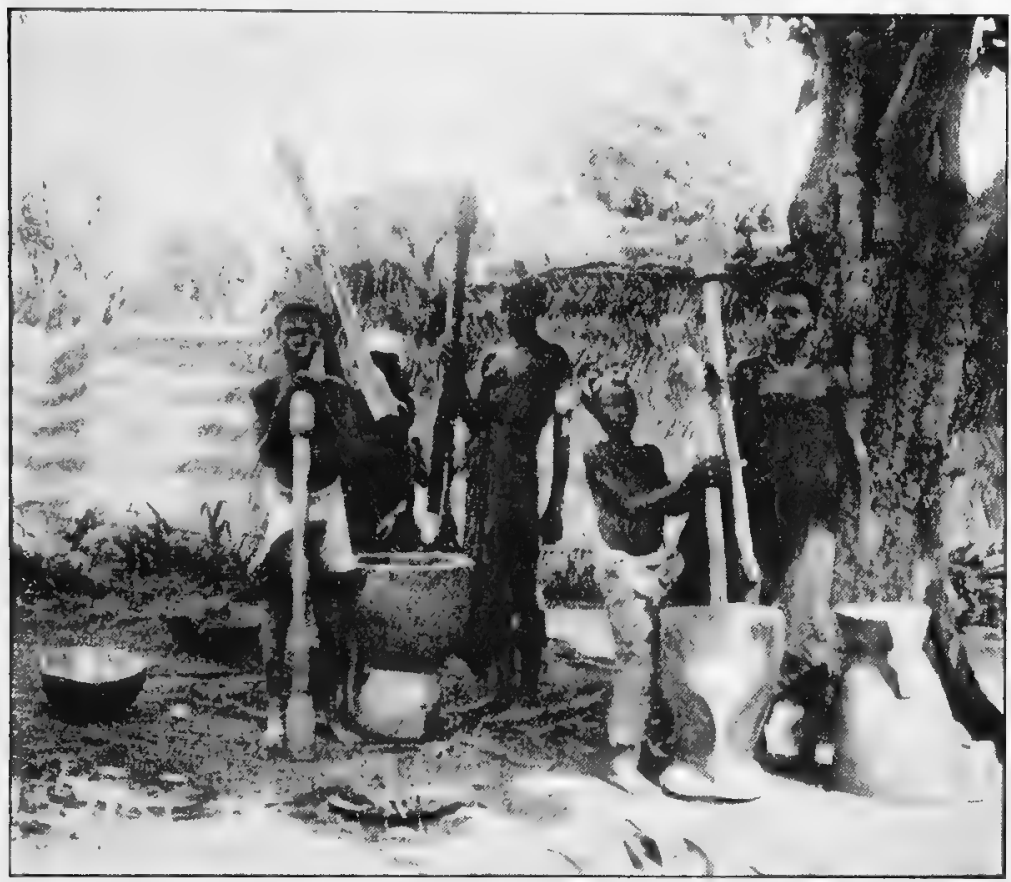

NATIVES NEAR YELUA, GRINDING CORN

piece of devil's work the instrument seemed to him, we feared that his raptures must have been somewhat wanting in sincerity.

A great many Hausa traders were in the town, which is a fief of the King of Wasé, so there was plenty of life in the market-place, in spite of the prevailing scarcity of food. It was interesting to see the women and girls grinding the corn for our carriers in their quaint jar-shaped wooden querns. When several women grind together, they 
usually raise a not unmusical chant, keeping time with their clubs.

On Mily 8, just before beginning our march, the head-man

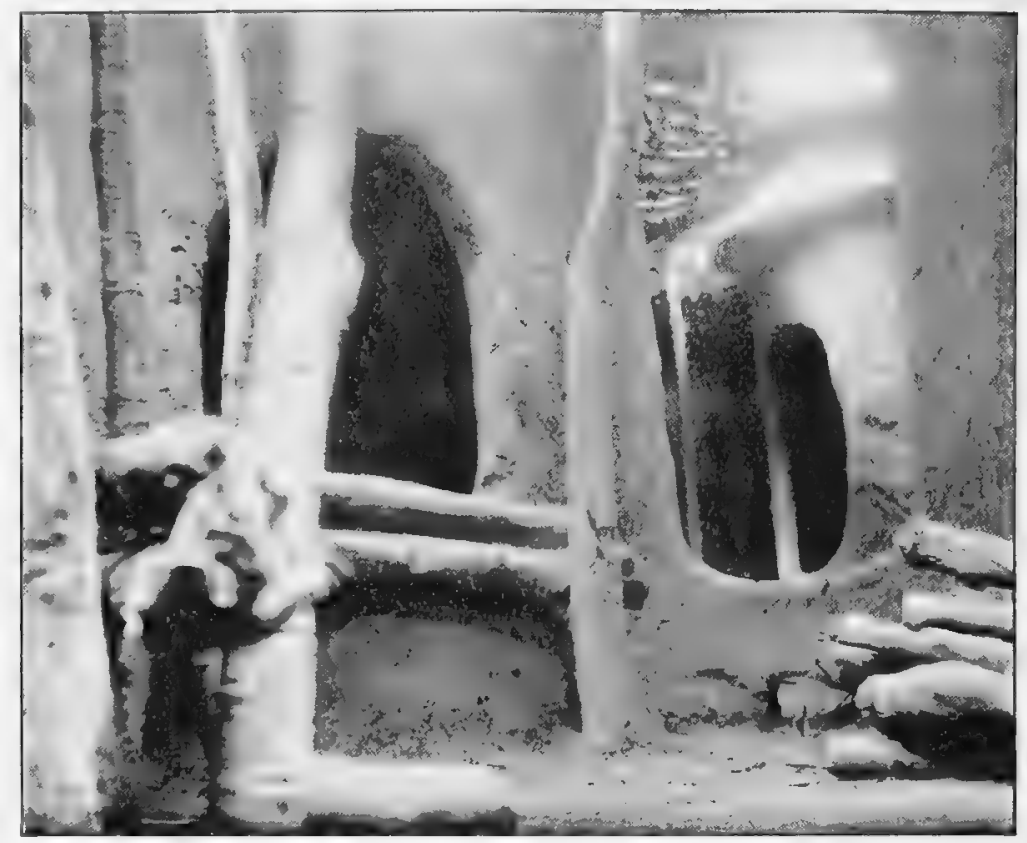

DOORIVAY OF A MONTOH, HUT

of the carriers, accompanied by an interpreter, came up and asked me not to stay behind on the road, as I often did to get game, as the Montoil might try to shoot the gun- or waterboys who accompanied me. This was his politely indirect way of stating the fact that they probably might shoot me.

We then passed through the last Ankwe village of Giddan Kwoim (Giddan means "house of " and the word following it is usually the name of the head-man or owner of the village), and next entered the country of the Montoil. These, with their neighbours, the Gurkan and the Yergum are aboriginal 


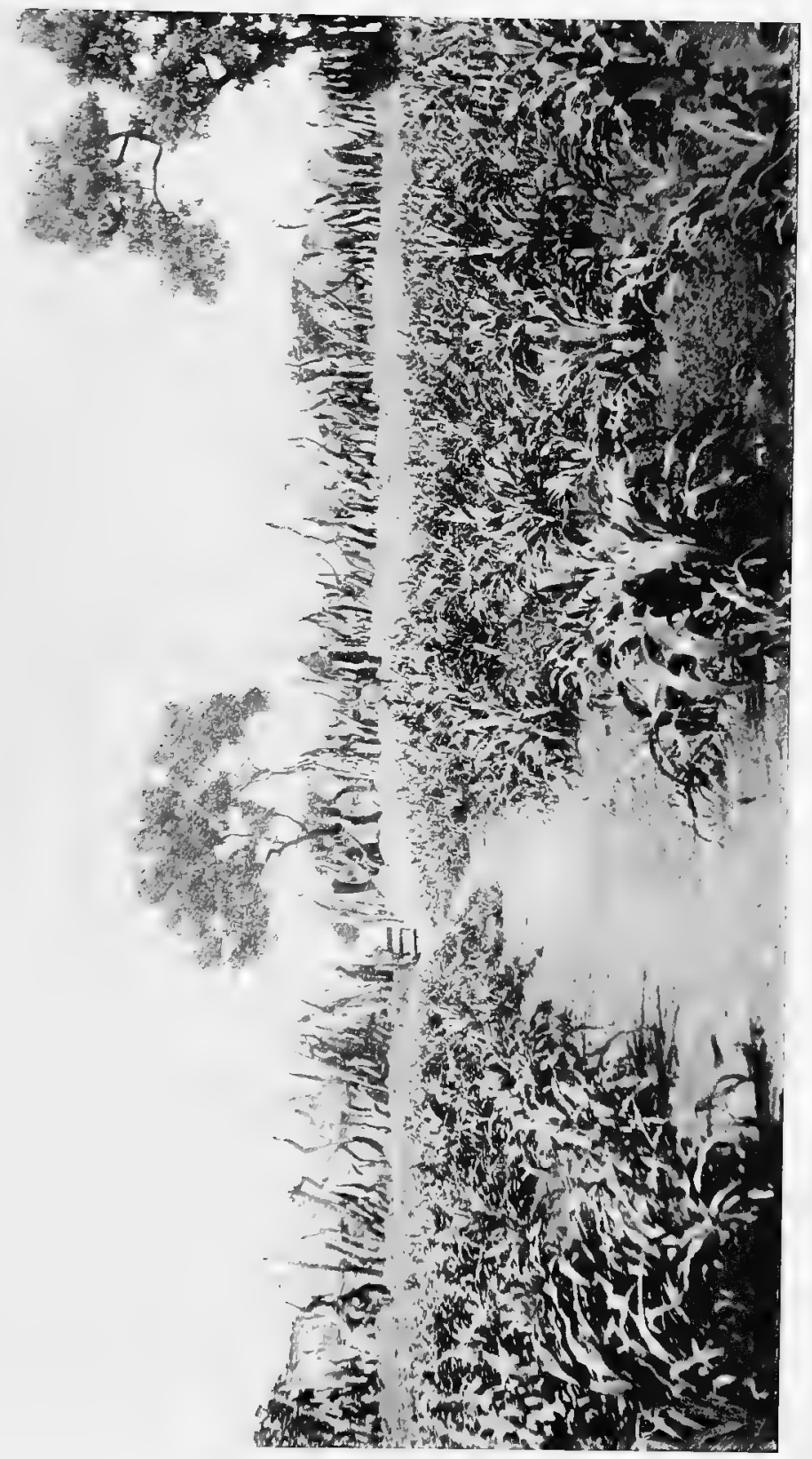

8 

tribes, who live at the foot of the Murchison Range. They are quite uncivilised pagan cannibals. Some of the Yergum, whose land stretches almost to Wasé, show traces of civilisation, but there is little doubt that the greater part of even these are cannibals whenever the chance occurs.

The Gurkaua live among the hills which bear their name, and the Montoil in curious groups of hamlets scattered round the foot of Mount Madong. The Yergum dwell to the extreme east, some at the foot, and some high up on the Range. The two latter tribes live, as a general rule, in sets of hamlets, a typical one of which would consist on an average of about sixteen circular mud huts, each about $6 \mathrm{ft}$. broad with a thatched roof and perhaps half the number of similar smaller huts used as granaries. The huts of a hamlet are all more or less joined together and closely surrounded by a stockade. Five to twenty of these hamlets scattered over about half a square mile would form one village. Most hamlets contain one family with its different branches. The early state of their civilisation is shown by the fact that they have not yet evolved as far as the village stage. Each hamlet is against every other, each village against the next, each tribe against its neighbour-one might almost say that the hand of every man is against every other man, as was shown by several very revolting murders which took place during our stay. On one occasion we came across a tragedy in the bush-an old man and two others killed and the blood not yet dry. To tribes who have been brought up under those conditions of relentless warfare in which every one preys on those weaker than himself, a sharp lesson is at first needed, but they soon find out that if the white man prevents them 
from attacking others he also protects them from attack. This salutary lesson had now been given to the tribes in question, and had already produced good effects among the Yergum, though less among the other two tribes. All these

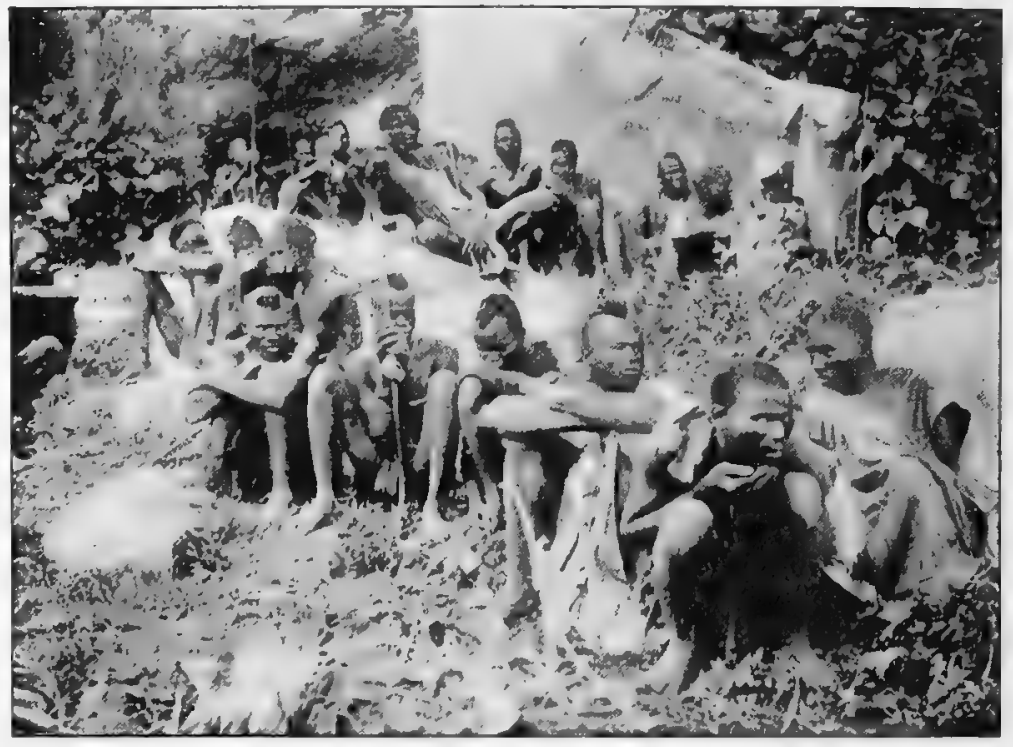

YERGUM PAGANS

tribes, Montoil, Gurkaua and Yergum had much the same type of features, and seemed to be closely related. The favourite mode of wearing their hair was to let it grow in a strip or ridge on the top of the head, and keep the rest clean shaven. The Gurkaua women wear two rows of leaves either in front or behind according to whether they are married or not. The men usually wear skins or pieces of native cloth, thrown not ungracefully over their shoulders.

There is, of course, this to be said for the pagans. In attacking the civilised Hausa and Fulani, they are but striving to avenge themselves on their natural enemies, who, year 
by year, have driven them further into the hills where their horsemen are comparatively useless. This is just what they themselves have done to the former inhabitants, whom they drove right up to the peaks of the range, where the latter

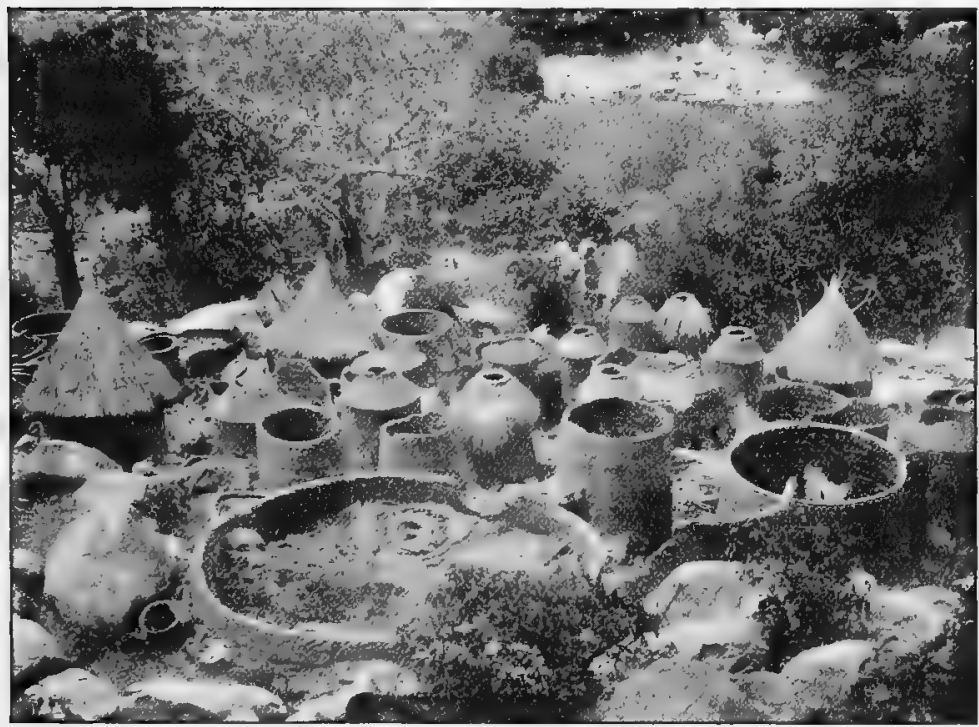

BCRNT GURKAUA VILLAGE-HUTS AND GRANARIES

now lead a precarious existence. In some ways the pagans are pleasanter to deal with than their more civilised conquerors. They are comparatively frank and trustworthy in their dealings, and far in advance of the others in every thing which concerns agriculture. It was wonderful to see how these pagans had irrigated and cultivated their fields and taken advantage of every available scrap of soil on the hillside. I was told that the tribes to whom reference has been made above, who have been driven to the very top of the Range, are called Gazum to the east, Pe near Mount Madong, and Fekk to the west. They are very hostile to 
one another, and are continually raiding their supplanters below, to get captives. We were very sorry that it was impossible to get into communication with these primitive

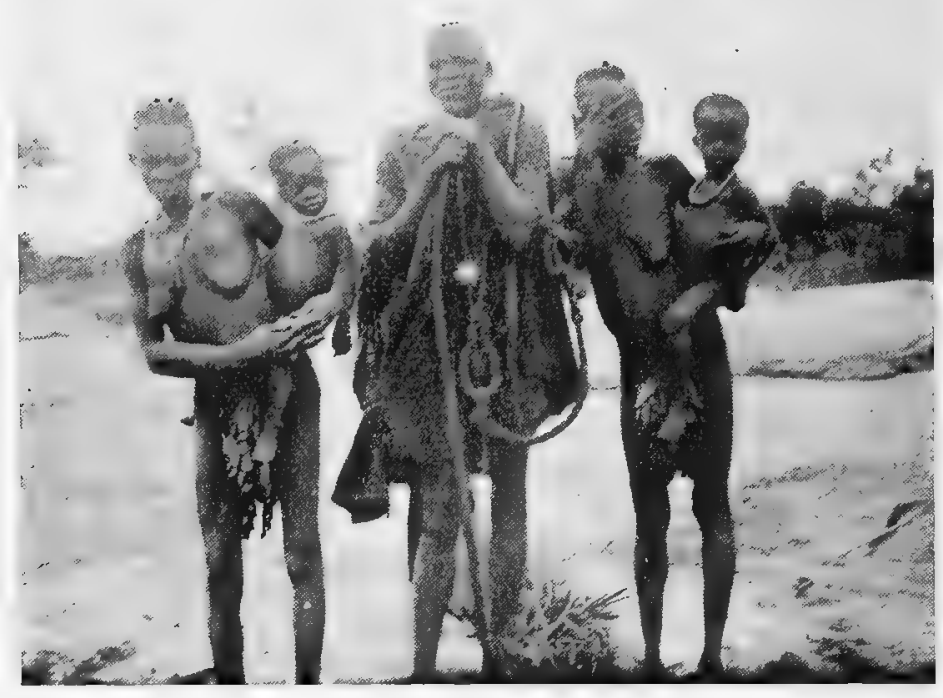

YERGUM PAGANS

peoples, as they would, from their still greater antiquity, have probably been even more interesting than their conquerors.

The Yergum told me that the Gazum people have tails about $6 \mathrm{in}$. long for which they have to dig a hole in the ground when they sit down. But I should think these tails would require a pretty good sprinkling of salt before they could be laid hold of.

The first big Montoil village we came to was called Shan Kwoim. It was not typical in any way, as, like others to the east, it has been touched by Ankwe influence, and 
consisted of one village surrounded by a stockade and trench rather than a collection of hamlets. The place was deserted except by its old chief, who was either too brave or too weak

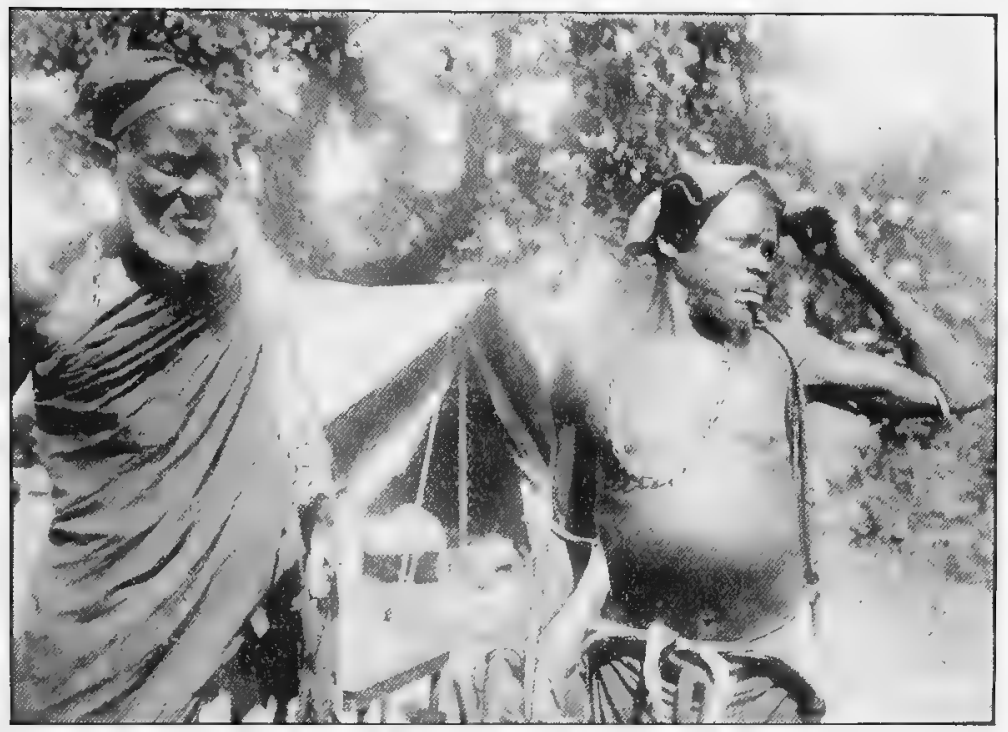

YERGTA PACANS

to flee with his people. He brought us a fowl and said that all the other people had fled in fear of us. We told him to send out and say we wanted them to come in and sell their food. Afterwards a certain number did come and we got a fair amount of meal but not enough to ration all the carriers. The old chief was highly delighted with a looking-glass and showed it by sprinkling dust on his head. From this chief I bought some curious twisted spears, which are some of the most barbarous-looking weapons I have ever come across. As a rule, however, Montoil spears are very primitive, with bamboo shafts, and points which are often not barbed at all. They are usually poisoned. We were fortunate enough to 
get some of the battle-axes which among these tribes are used both by men and women. The shape of the head bears a curious resemblance to the conventionalised Egyptian lotus, possibly the idea for this design was got from their neighbours and constant invaders, the Fulani.

From this place we had a very fine view of the main range and easily recognised the principal peak which we had observed from Ibi. We found that the Montoil name for this was Mount Madong. To the west lay a valley, beyond which the range was continued, and, to the left of this, a remarkable rock which we had before noticed, was now clearly to be seen. The Hausa name for it is Mata Fadathe fallen mother, as they imagine that its outline somewhat resembles that of the breast of some beneficent goddess of the hills. This rock is too noticeable to be overlooked by any one passing through Yelua. Seen from a short distance, it is a sheer pinnacle of enormous size. The resemblance of the Hausa "Mata" for Mother, is so close to the IndoEuropean word, that it is only another indication of their eastern origin.

On May 9 we set out straight for Mount Madong, and after two hours' march through a well-cultivated country thickly dotted with hamlets, from which, however, all the inhabitants had fled before us, we arrived near the foot of the mountain. The column then halted, and I went on ahead with two soldiers to reconnoitre the western flank, and see if it appeared more accessible than the part which now faced us. It was a good thing that the soldiers were with me, as, when we came into the valley which is surrounded by hills on all sides, except at the narrow entrance, we found Montoils posted 
in every direction and we could hear their whistling signals all around us.

I took up a good position on a little hillock; then, as nothing happened, made my way back to Alexander. We all encamped on the site chosen and posted sentries. Unfortunately Alexander was now obliged to own to an attack of fever, which he had been trying to hide for the last two days, and had to take to his bed. Next day he was a little better, so, with two soldiers and my gun-boys, I set out to see what the valley was like. It would have been exceedingly difficult, if not impossible, to have got the theodolite up any side of Mount Madong which we had yet seen, and we hoped to be able to attack it from the rear.

We accordingly marched up the valley, by numberless deserted hamlets, and along the banks of a small stream which we took to be one of the sources of the River Simanka. The valley turned out to be a cul-de-sac, surrounded on all sides by a precipitous wall of hills. Half way my men wanted to turn back for fear of the many Montoils in the hills, but were with some difficulty persuaded to come on. We then climbed the mountain at the end of the valley. Here such a dense mist prevailed that nothing could be seen to the north. It was out of the question to break through the range here with our baggage, and with no knowledge of what lay beyond, and anyhow, no horses could have passed that way.

On our return, we captured a Montoil, and took him with us to camp, whence he managed to escape next day, much to the sorrow of the soldier deputed to guard him. Owing to his report of the kindness with which he had been treated, however, an enterprising chief came soon after to 
pay his respects. He was an interesting old man, though very difficult to talk to, as my remarks were translated by

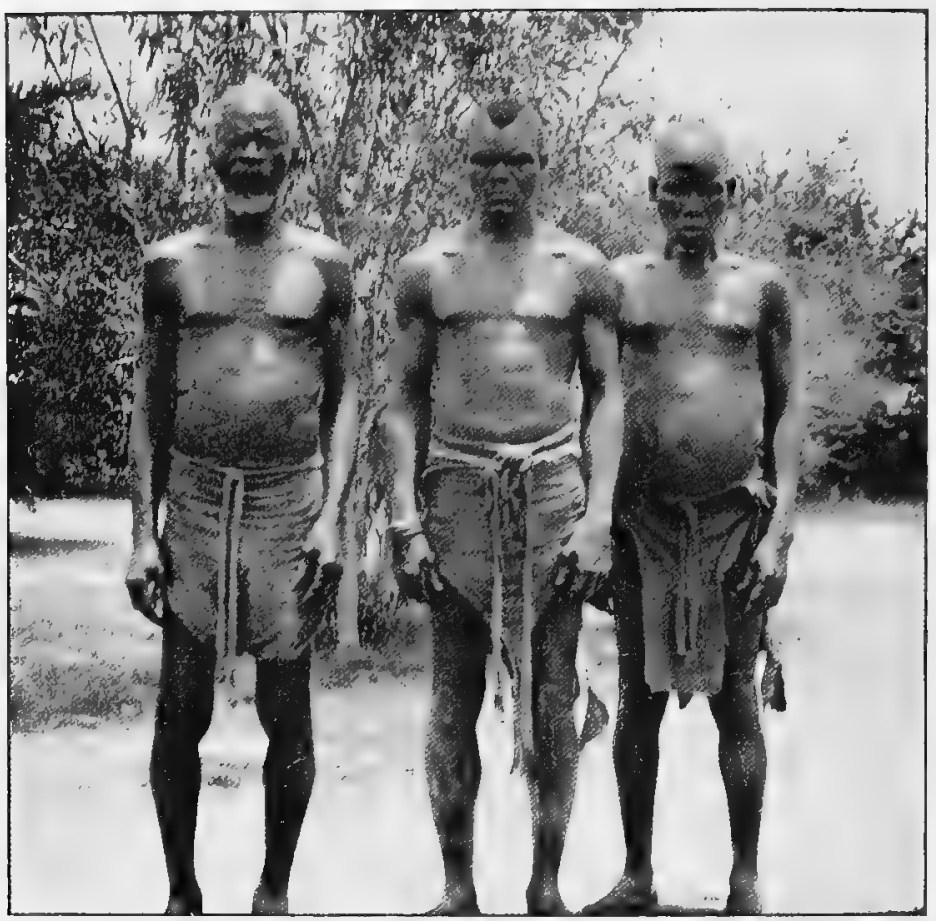

MONTOIL CANNIBALS

an interpreter to a Yelua man who happened to be with us. He, in turn, repeated them to a man from near Yelua, who could speak the Montoil language, and passed them on to the chief. The answers, of course, came back the reverse way. He left us next day, loaded with presents and expressing the greatest regard for the white man.

Alexander had grown worse during my absence. His temperature had risen to $105^{\circ}$, and on May 11 he was not much better, so a hammock was made, and next day we 
started to carry him into Wasé, where an English doctor was with the troops. It was two days before we reached our destination.

On getting within a safe distance, a man was sent in to prepare the doctor, so, on our arrival we found that Dr. Ellis had kindly arranged for a house for us, and made everything ready. As a matter of fact, Alexander had greatly improved by now, owing to vigorous doses of quinine, but to my disgust, I was myself at once ordered to bed. I had not been feeling well since Yelua, and now a slight attack of dysentery had developed itself.

At the end of a week, Alexander was quite recovered and went out to reconnoitre the Murchison range again.

On May 22, I got up to observe an occultation of the moon, which was successfully carried out, though the necessary exertion put back my recovery. I was very glad afterwards, however, that it had been done, as it proved to be the only successful occultation obtained throughout the work. Of all other observations of the moon carried out for this particular purpose, each one was spoilt by rain or clouds at a critical moment, though observations were made of every occultation that could be visible out there.

On May 25, I heard from Alexander that he had tried the ascent of Mount Madong but could not get to the top. His letter continues: "I got down again 'more dead than alive after six hours' continuous arm and leg work. I find it best to climb in socks .... Our friends the Montoil tried to make an offensive and defensive alliance with me this afternoon, but I only consented to the latter. It seems there was a bit of a palaver to-day, I heard a great shouting 
and saw Montoil hurrying to the scene of action from all directions-their casualties, I hear, were two wives. Whatever you do, don't hurry away from milk and Wasé- There's none to be got from the Montoil, who don't 'savvy' how to do the operation. They are very niggardly in their contributions of meal, but bring any amount of eggs and chicks, in embryo and otherwise. I believe most savages get a bit hard up for corn just before their harvest time."

Two days later, I had another letter from him, from which it was evident that the best way of connecting the peaks was by triangulation from a measured base at the bottom.

On May 26 a letter came for me from Gosling at Ibi, to ask Alexander to go back thither at once, as it was feared that his brother had black-water fever, and to beg the doctor to set out immediately. This Dr. Ellis kindly did and went straight through to Ibi without stopping. I mounted my horse-boy and sent him off at once to Alexander, whom he could not find for some time, as appeared from the following letter which crossed mine.

"Dossuma" [one of the soldiers] "has just arrived, and I was glad to hear he thought you better. He brought no note, but said your horse-boy had already left with one, I hope he hasn't been ' chopped.'

"I have heard from Bauchi that they have no objection to our going through the Angos country.

"I have fixed upon a base about three and a quarter miles long, and put up flags. The distance can easily be determined by measuring a shorter base in between, and this I will work out to-morrow. The two ends of the proper 
base are on small hills from which one can see practically everything. I have plotted the triangles roughly for compass bearings and they look all right."

At once on receipt of this a second messenger was sent out, who, I was glad to know, could carry a more hopeful letter about his brother, which had just come from Gosling. The carrier succeeded in reaching him at Lakushi, after my first note had arrived. He said in reply:

"The bearer reached me at about 8 P.M. which $I$ call good going-especially as he had been round by Giddan Galadima. I gave him meat and meal, and shall "dash" him $2 s$. before he goes back to-morrow with this. Many carriers would not have gone alone into this country. As for your horse-boy, I think he deserved great credit for having penetrated right on to Mount Madong camp.

"I shall go on to Ibi as I have got so far, I expect to be there on the 31 st and shall try to get back to Giddan Galadima as soon as possible, unless you'd like me to look you up at Wasé. If you write, let me know what you think of the proposed base.

"The country has altered a good deal since we passedthe corn-fields are 11 to $12 \mathrm{ft}$. high, and the Simanka quite a good river."

On June 2 he wrote again from Ibi, saying how serious his brother's illness had been. The latter was now slightly better, but they were having great difficulty in persuading him to go down to Lokoja for a rest, instead of up country as he was determined to do.

It now became necessary to have frequent communication with Ibi from Wasé, and we were fortunate enough to 
lose none of the messengers at the hands of the Yergum and Gurkaua who were then on the war-path. During my stay at Wasé, a man was sent round to me from the king. $\mathrm{He}$ and a friend were going from that place to Yelua when the Gurkaua came out and killed his companion, while he escaped back. He brought with him the poisoned arrow which he had drawn from his friend's body.

For some time now, I had been feeling well enough to take quiet rides in and round the town. A few years ago it contained over 10,000 people, but now there are not more than between two and three thousand, owing to the famine which has been prevailing there.

The ruling classes are composed of Hausa and Fulani, the lower classes from pagan Jukum and the surrounding tribes. My collection of calabashes was here greatly increased and the poker-work designs on many of them showed that some of these people, especially the Hausas, have an unusual sense of the value of line.

Like most walled towns, the ground inside Wase is partly taken up with compounds, each of which consists of five or six huts, grouped round a small space, and enclosed with a mud wall. These are generally occupied by one family, and its branches. The size of the compound varies with the importance of its owner. The rest of the space inside the walls is filled with millet and guinea corn. In the midst of these fields a high erection is generally to be seen on which sits a boy who is continually calling to frighten off the birds, and the people for the most part are engaged scaring them away by shouting and pulling strings on which are suspended old gourds, calabashes, \&c. The town wall 


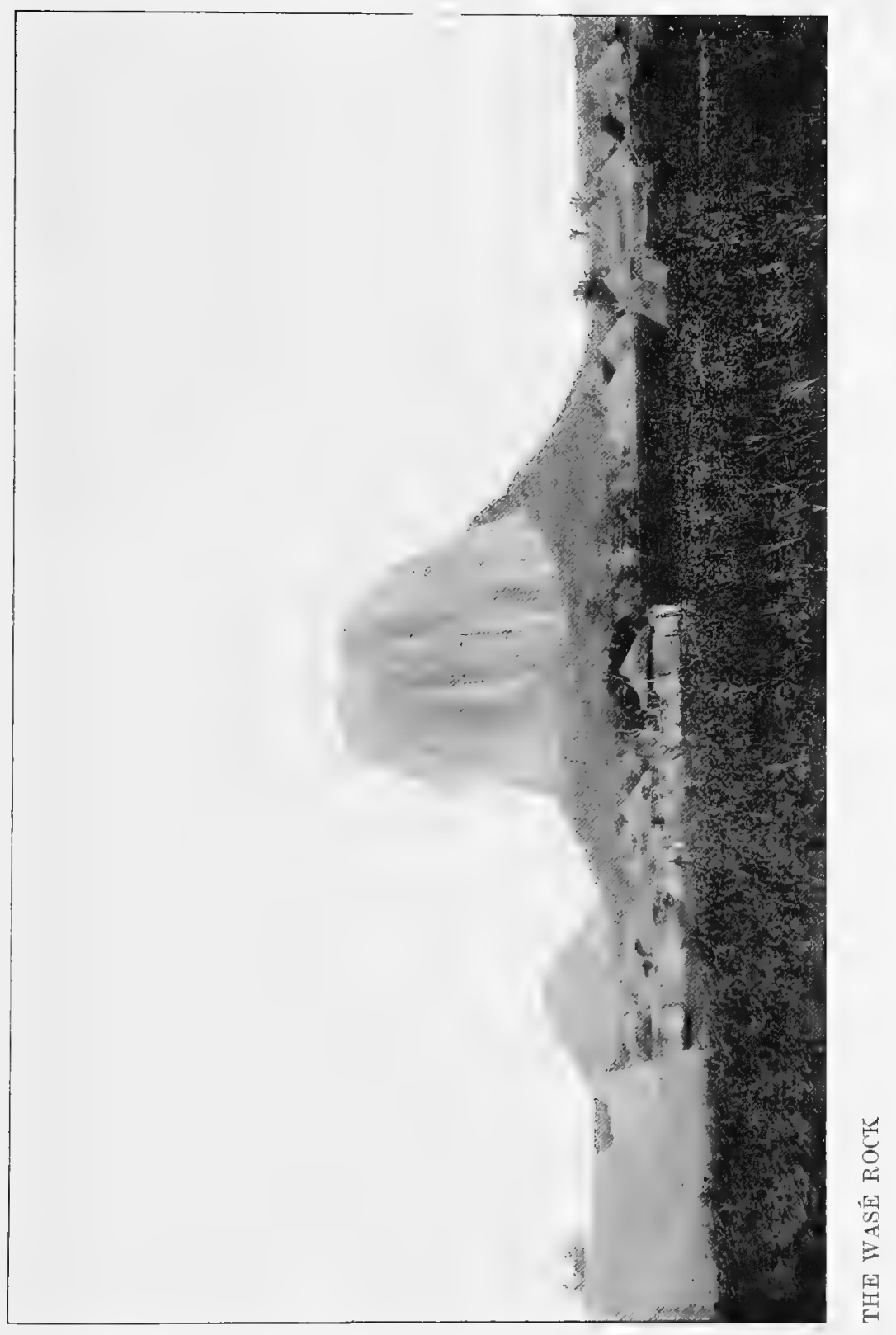



is decayed in places now, and many of the compounds are deserted.

About half a mile to southward stands the celebrated Wasé Rock, an immense mass of igneous rock rising sheer out of the plain. It is about $1000 \mathrm{ft}$. high and was, as far as I could judge, the pipe of a volcano, of which all the rest had been denuded away. Around this innumerable legends have sprung up. It is supposed to be the haunt of evil spirits, and I was assured that two blackmen had, at different times, climbed to the top, and both these had been seized with madness, either as a punishment for having dared to invade the haunts of the demons of the mountain, or else through horror at the sights which they had witnessed.

The shooting round Wasé was luckily very good, as owing to the famine it would otherwise have been very difficult to feed my carriers. In the space of an hour one could generally get as many francolins (a kind of partridge), guineafowl, pigeons, or wild duck and geese as one wanted. There were also plenty of reed-buck and larger game, and quantities of the beautiful crown-cranes. To the south of the rock, too, I shot a leopard, but it unfortunately got away.

The Wasé river is a typical example of the streams of the country-one day it swirls down, full to the brim, $5 \mathrm{ft}$. deep and difficult to cross; and the next, the natives may be forced to dig holes in its sandy bed in order to get water for cooking and drinking. Later on, we came upon the source of this stream. 


\section{CHAPTER V}

THE SURVEY CONTINUED TO ASHAKA

(Written by Mr. P. A. Talbot)

ON June 18 news came from Gosling that Boyd Alexander was much better; and that he and Claud Alexander were soon leaving Ibi and hoped to reach the Murchison range about the 22nd. By this time I was quite fit again and set out on the 20th for the neighbourhood of Mount Madong. When close to Giddan Galadima on the borders of the Montoil country, the inhabitants never waited for us but ran away. To show the low state of civilisation of these people, the -women on our approach threw down their babies with the intention no doubt of stopping the advance by staying our appetites. At night fires were lit to communicate our arrival from one village to another. I sent out messengers to say we were friendly, and not an expedition that was coming to burn and destroy their country, but they only replied: "We do not trust you."

In the village the corporal in charge of the escort found a man tied to a log. This turned out to be a prisoner of the chief, who had been secured in this way to keep him safe for eating on the morrow.

The native huts are well made, with conical roofs; they are very small and the doorways are just big enough to pass through. There is one hut for their goats, another for 
their fowls, and another for their grain, shaped like a jar with no entrance, to get at which they use a notched pole as ladder. I found hanging up in one of their houses the skin of an animal I did not recognise. I bought it at the price of a handkerchief and gave it to Gosling. It turned out to be a new animal, and to my great pleasure is called "Procavia Goslingi" after him.

On the 21st we marched to a collection of hamlets called Purmi and found the place for a base which Alexander had selected. The natives, who had taken away all the survey flags which he had planted there, were very hostile, and we had to keep a sharp look-out. One of the soldiers climbed a tree, so as to have a better view, and was just in time to warn us that some natives were creeping up in the grass towards us. When they saw that their presence was known they retired to a distance without doing any damage, though some of their arrows fell unpleasantly close. A man, whom we had brought from Wasé, bravely offered to try to explain our peaceful intentions and induce some of them to come and talk. They refused to answer his shouts, and when he tried to approach them let off several poisoned arrows. One or two of the bolder spirits also tried to rush a soldier, who happened to be a little way off the others. To save himself the latter was obliged to fire at them twice. The attitude of these tribes was the more regrettable as our friendly intentions had been clearly explained to the two chiefs whom we had met, and must have been conveyed to them.

A little later, my horse-boy, who had only gone out about a hundred yards to cut grass for the horse came back in great excitement with four freshly poisoned arrows which had 
been shot at him. He gave quite a dramatic representation of the agile way in which he had dodged some spears which had also been thrown.

For the next three days the carriers were hard at work levelling and making a base for triangulation. Our days were now fairly occupied and work went on late into the night. The work was enlivened by a raid made by a few Montoils on June 23 on a hamlet where most of the carriers lived, about a hundred yards off the one occupied by myself. According to his own account, the sentry fired at the attacking party, but they did not clear off till the two soldiers from my hamlet hurried up as reinforcements. The affair had its ludicrous side, as the assailants nearly succeeded in capturing a couple of the carriers' wives, which resulted in hysterics from the ladies concerned for the rest of the evening.

Hearing shots, I hurried up from the other end of the base, and found that the Montoils had made a clean sweep of everything which the carriers had left in the huts-food, clothes, and all other possessions. This loss was most felt by the dandies among the carriers and by their ladies, who had to go without cherished pieces of finery until they got a chance of replenishing their wardrobes at Bauchi.

All this time great fires could be seen at night, to the north, north-east and north-west, and we were told that these were caused by the Yergum, raiding the Montoil and the Ankwe. The same evening a shot was heard in the direction of Giddan Galadima, and thinking it was a signal from Gosling and Alexander, I sent some soldiers there early next morning and found that they had arrived, though the shot had only been fired at a guinea-fowl. An hour or two 
afterwarels they buth came in. By the aftermonen the base was finished and meisured. The next fow days were orerupied

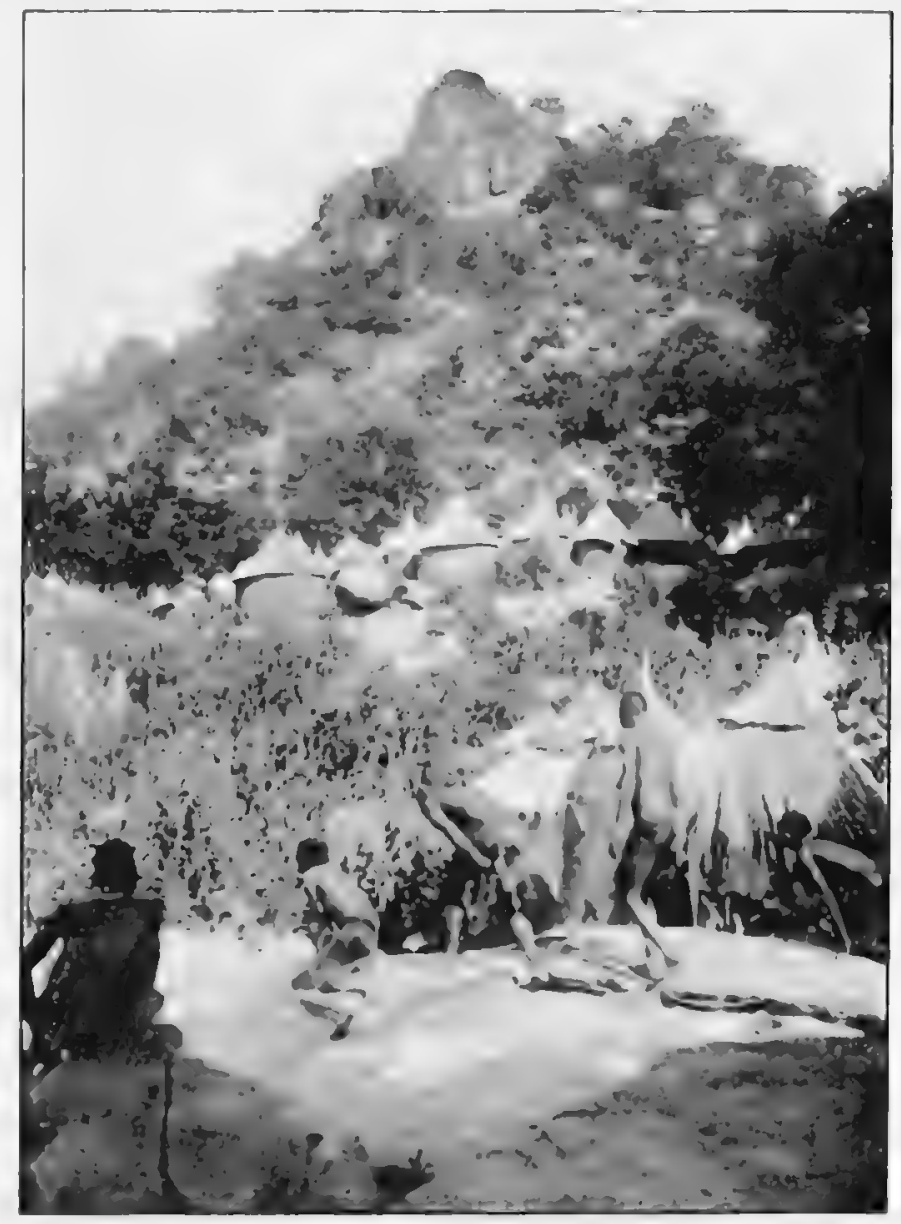

MONTOL PAGANS RUNNING AWAY FROM THE SURVEX PARTY

by dlexander in platne-tahle work and by me in triangulation, which was rendered rather difficult by the fact that our signals were so often stolen, for the sake of the small pieces of eluth on the flag. It this time our labours went on late 
into the night. There was star work to be done before our last meal at 9.30-and then Alexander would work the photography till past eleven o'clock.

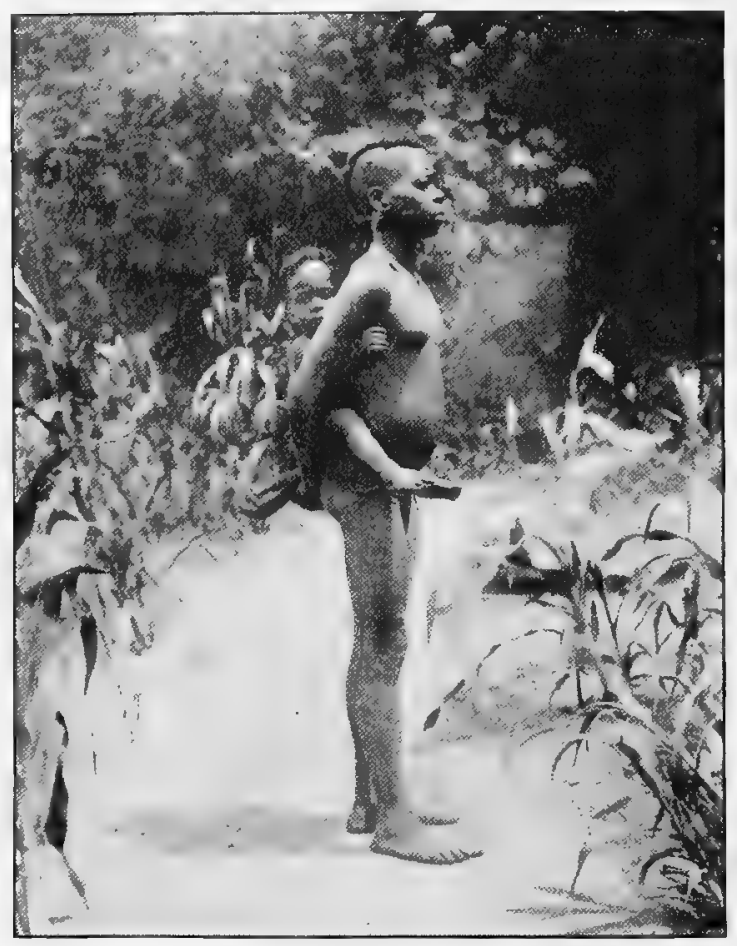

YERGUM MOTHER AND CHILD

On the 27th we went on by slow stages round the eastern foot of the mountains to Langtam, where we arrived on the last day of the month. On the way Alexander shot several of the little rock dassies. When near Langtam, his pony died from tsetse fly, and the Yergums had a beanfeast.

Langtam itself is a big collection of pagan villages, the capital of the Yergum. Here we managed to get in touch with the people, and had a big palaver with the chief and 
his principal men. They asked us to join with them in attacking three tribes who lived on the top of the mountains, and were their hereditary foes. Two days before, these latter had carried off five of their men. They were consider-

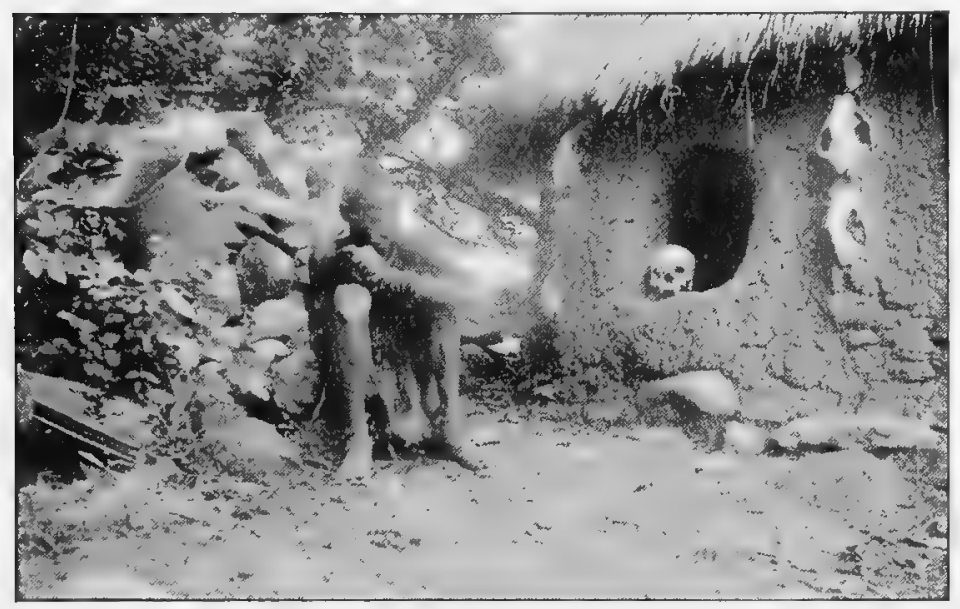

THE WTZARD OF THE YRRGUMS

ably disappointed when we declined the proffered alliance, or at least its offensive side.

The Yergum women do not burden themselves with much dress. Beads and bracelets of woven grass are worn with a bunch of leaves in front or behind, after the custom of the Gurkaua women to whom I have before alluded.

It is the prevailing custom that a girl's first child should be born in her mother's house before she goes to the home of her husband.

In the afternoon Gosling and I climbed the hill to visit the great Juju place of all the Yergum, the dwelling-place of the greatest magician for many miles around, who pretended to foretell the future to those aspirants who brought goats 
to be sacrificed, and who also constituted in himself the Court of Appeal, where all disputes and difficulties were finally referred. The skins of all leopards and lions killed in his territory had to be brought to him, though he gave back many of them. We did not return very impressed by what we had seen, except perhaps by the number of human skulls which were in and round his hut. On July 1 Gosling left us for Ibi, on his way making a hunting expedition to the north-east of Wasé, where he shot his giraffe.

Next day Alexander and I went to Brott, the capital of the second chief of the Yergum. It stands in a beautiful valley between some of the outlying peaks of the Murchison range and is thickly dotted with hamlets. Here we made a fine haul of sheep and goats, which were presented to us by the King of Brott, for our success in inducing a rebellious vassal town to submit to him. He tried hard to persuade us to join him in making war on his enemies, the hill tribes, and undaunted by refusals, made a pathetic last try when he came on with us part of the way next morning, and then, pointing to some men lining the tops of the hills, declared they were Gazum, who would catch and eat him as he went back. We watched, however, till we saw that he had safely rejoined his own men.

After leaving Brott, we tried to break out by a valley to the left, which would have saved us a long détour, but could not, as it grew too steep and rocky for the horses, good climbers though these were. We now came out at the back of the range, and passed into territory where no white man had been before. We had been assured at Wasé that the peoples into whose territories we were now entering, were 


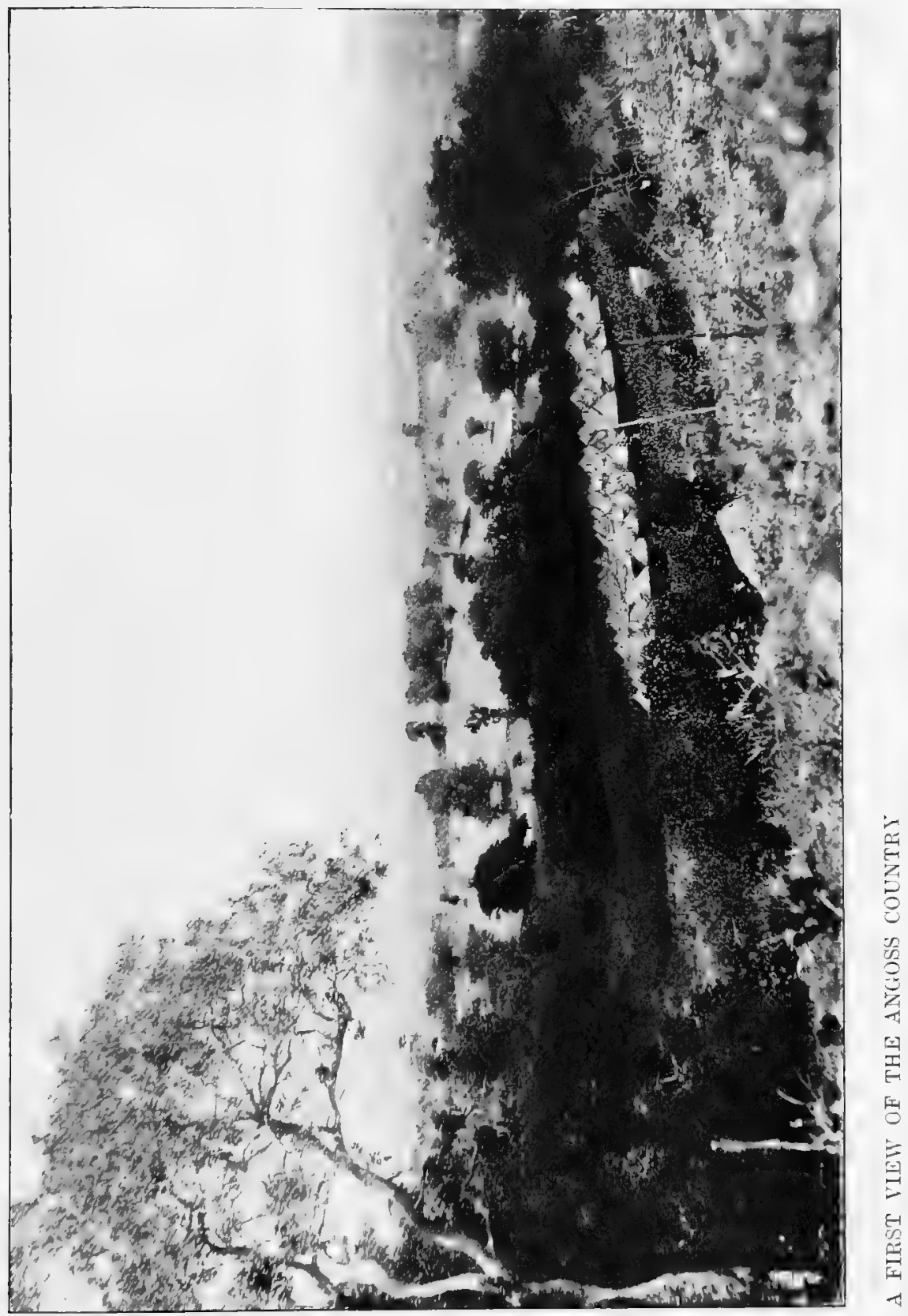



particularly fierce cannibals, and that we ought not to venture into their country without at least a column of soldiers and a maxim. As a matter of fact, we found them most kind and hospitable.

About 11.30 we reached the valley of the Yunna river, the source of which could not have been far off, and we were told that this was the same stream as that at Wasé. Before us on the top of a long precipitous ridge we saw the first Angoss village. The chief came down to us, but his people fled, and we could not get much food for our carriers. In the afternoon Alexander climbed the hill to do some planetabling, and next morning ascended the Vrukk Hill for the same purpose.

It might perhaps be mentioned here that we both took the greatest care to get the spelling of all names according to the rules of the Royal Geographical Society. We invariably adopted the word as pronounced by the chief of the village, and in case of mountains, the names as given by the people living nearest to them whenever possible. Alexander showed a wonderful natural aptitude for getting the sound of the word, which, as any one with African experience knows, is no easy matter. In fact the whole time we spent together was to me a series of revelations of his remarkable ability for everything he took in hand.

From now onward, instead of scattered hamlets the people usually lived in large villages without any stockades. The scenery was magnificent and the air bracing, which was no doubt due to the fact that we were now about $2000 \mathrm{ft}$. above sea-level.

We stopped for the night at Shwer, where the people 
were very friendly, and brought us plenty of food, and on July 5 we marched on to Dugurh. All through the Angoss country the route was hilly and rocky. So hard indeed was the ground that one of my horses could not be ridden again for two months, as its hoofs were worn down almost to the quick. About here too', we came across an extra: ordinary amount of mica-the path we followed shone with it like silver, and on either hand we could see great sheets of it. There is very little grass, and few bushes, and it must have been very difficult to grow crops in such a stony soil. The whole land was mapped out into little terraces, sometimes only a foot or two broad, built to hold up the rain as it ran down the hill, and prevent the soil from being washed away. In places no longer cultivated, only the dilapidated terrace walls remained, through the rents of which in course of time the soil had been blown or washed down. In this case one saw only low walls encircling a hill, and I cannot but think, though with deference to the views of Dr. Randall MacIver, that a similar cause may have led to the erection of the extraordinary systems of concentric walls, which exist in Rhodesia. It seems to me hardly probable that any nation should have constructed rows of even twenty parallel walls; so near to one another up the sides of a mountain, for the purpose of fortification. As a matter of fact, I believe that the number of concentric walls which have been found girdling a Rhodesian Hill sometimes reaches a hundred or more. The obvious objection to the irrigation theory is that the walls in Rhodesia are, I believe, several feet deep on the inside, while in Northern Nigeria they are seldom more than a foot. This might be explained, however, by 
the fact that in the former country the hills in question are steeper and the terraces broader, than those which we noticed in Nigeria.

Dugurh stands at the foot of Mount Ampang, which is

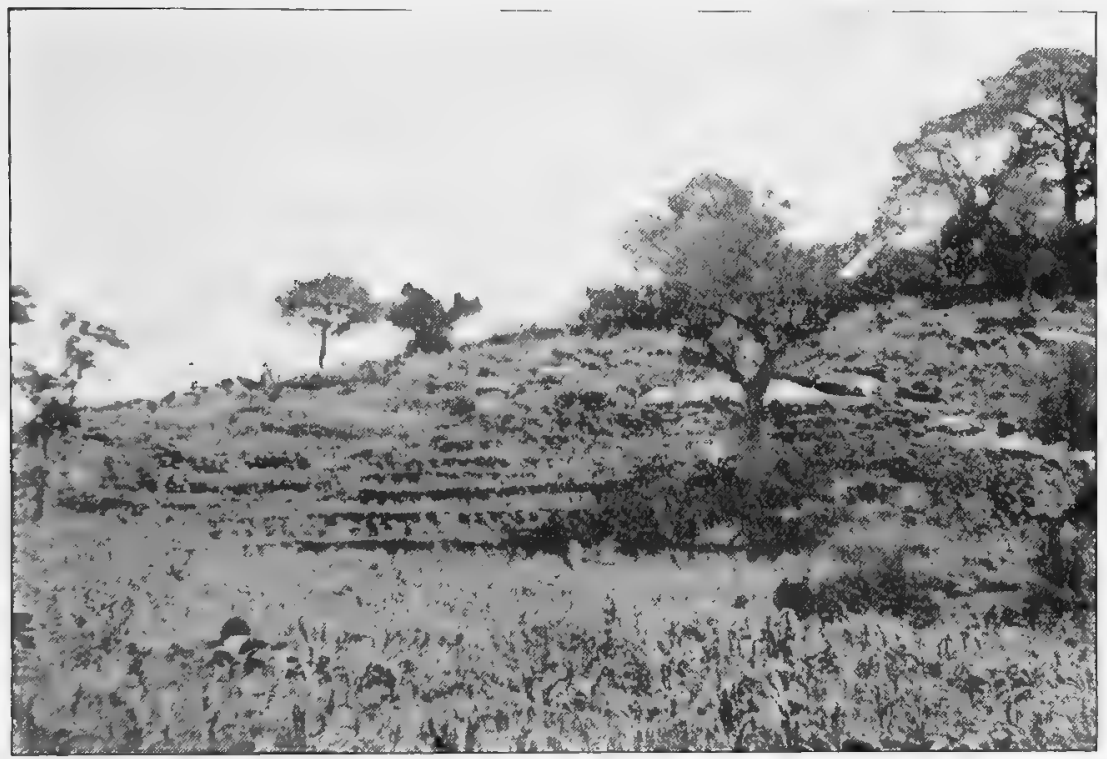

TERRACI CULTIVATION ON MOUNT AMPANG

over $4000 \mathrm{ft}$. high. We climbed this and found a large plateau at the top covered with populous villages. It was wonderful to see the way in which every inch of the ground was cultivated. Even spaces not more than a square foot in area, where a little soil had been collected, had been planted with millet or guinea corn, which is the ordinary food of the people throughout the country. Two or three hundred men surrounded us on our arrival and stayed gazing at us for hours without seeming to grow tired. They were a sturdy lot and very communicative. The Angoss women 
generally wore three rows of leaves both in front and behind, and were by no means beautiful. In times of famine, we were told they took their children to Bauchi to sell for food, as do all the tribes about here. Luckily, though their harvest had not been plentiful, there was no famine, as there was further north.

We camped in a small dell just below the top peak, from which we had a splendid view of the back of the Murchison range and other hills to the south-west. To the north we caught sight of some mountains conveniently placed just inthe direction in which we wanted to go, and to the northwest lay a magnificent range with peaks $5500 \mathrm{ft}$. high. These are, I believe, the highest mountains in West Africa, with the exception of those in the Cameroons. Although their height is not great when compared with those in other parts of Africa, yet they have an impressive grandeur of their own. Every tribe gave us a different name for this range, and therefore, with the consent of the Royal Geographical Society and according to the wishes of his family, I named them the Claud Mountains, after the brilliant and gallant young officer in whose company it was my privilege to spend the greater part of this, one of the most interesting years of my life.

On July 7 we left this mountain and marched into the territory of the Seaua, a tribe very like the Angoss, though the women here wear a number of bunches of twigs and leaves, instead of the three rows worn by the latter.

At Lusa, where we spent the first night, I had gone out shooting for our supper and had only a shot-gun with me, when I suddenly came across a lion, lioness, and two cubs, 
on a boulder about a hundred rards off. Ther looked at me in a very astonished way and then leisurely retired. By

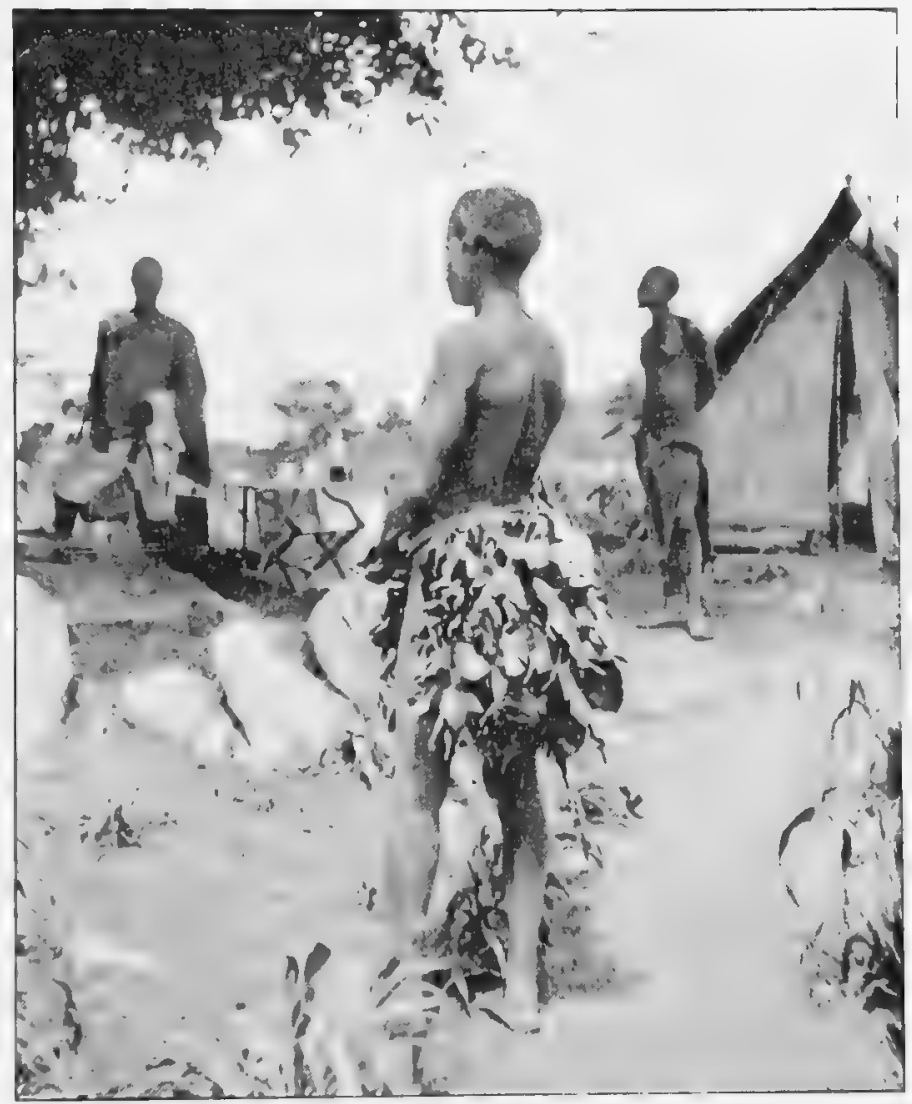

A WOMAN OF THE SEAUA PAGANS NEAR BAUCHI

the time I could get my rifle they had disappeared among the ravines, and though I searched for hours I only obtained one other glimpse of them on a distant rock. All through the country of the Angoss, Seaua, and Jaralli, there are a great number of rocks similar in shape to the one at Wasi, though in most cases smaller. It hardly seems possible 
that all these curious rocks should be pipes of volcanoes, but anyhow these and the whole lie of the land show that there must have been an extraordinary amount of volcanic disturbance here at some time. At Lusa there is a rock, in the clefts of which we saw many rock dassies. We shot several, but they died in their crevices, and although we both tried we found it impossible to reach them.

Alexander had an attack of fever here, but would not hear of my staying more than a day to look after him-besides which it would have been impossible to have got food enough for all the carriers for a longer stay; I therefore went on to Gital where he caught me up two days later.

On passing through Bagoro, the last Seaua town, I found the chief waiting for me with two bags of meal which he had brought out of his own accord, a thing which we flattered ourselves he would not have done unless our former hosts had given us a very good character. After this we had to cross two branches of the River Gital, the water of which was deep enough in parts to come over my horse's saddle. The carriers had great difficulty in carrying over the goats and sheep which the Chief of Brott had given us, and which, to our joy, provided us with fresh milk every morning. The Gital was the first river of any size which we had come to since leaving the Benue, and the carriers enjoyed themselves mightily, in swimming, splashing one another and bathing, as well as in washing their clothes.

At Gital where we entered Jaraua territory, we were not received with much friendliness, though the country was more civilised and the king lived in quite a big palace. Here the great baobab, or monkey-fruit tree, began to be in 


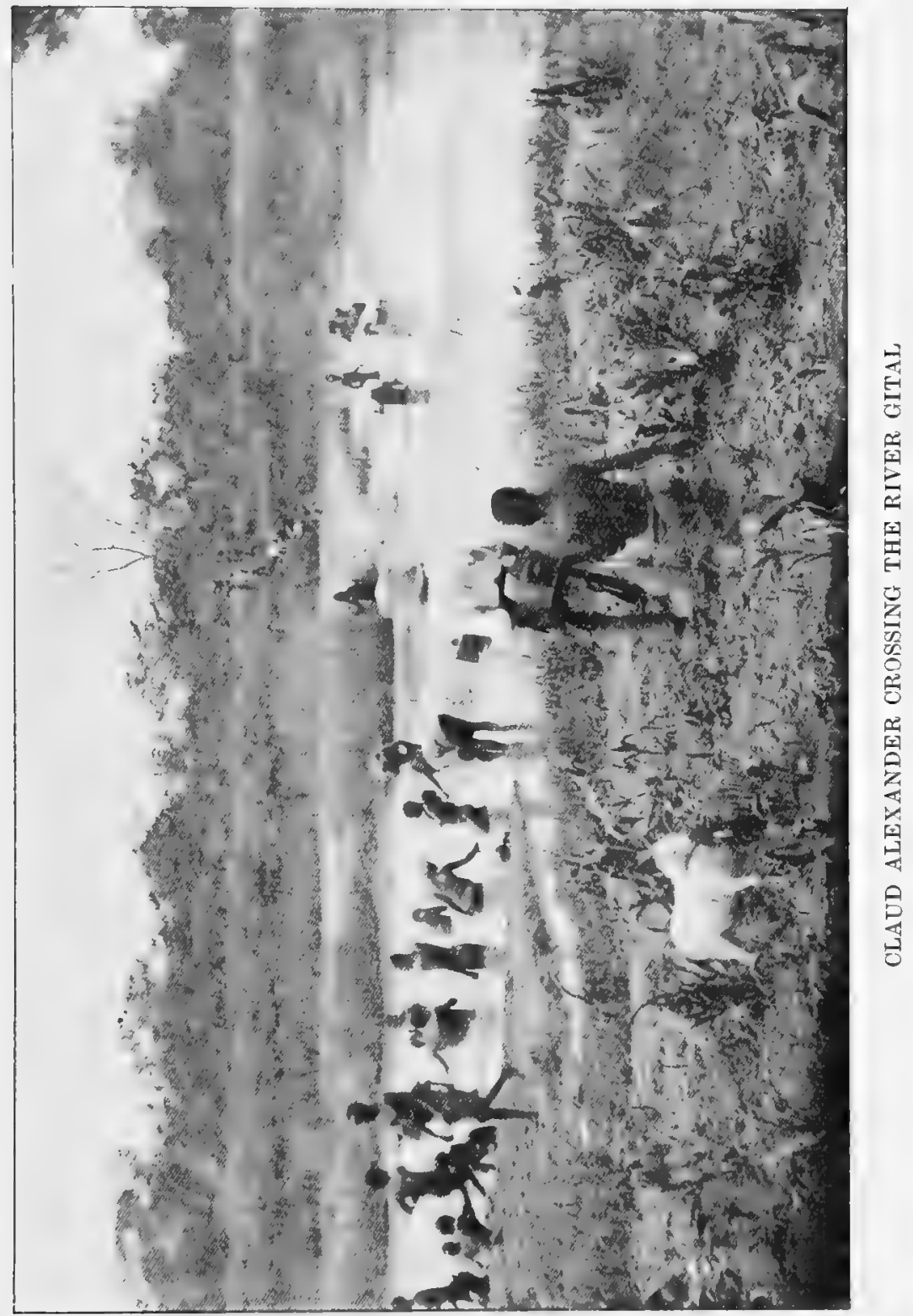



evidence. The one under which my tent was pitched had a girth of $57 \mathrm{ft}$., but this was nothing compared with some which I saw later in the Barburr country. It was now getting on towards the middle of the rainy season and for about a month from now we had an almost daily downpour, though the rain here is never so bad as nearer the coast.

On July 12, to my great pleasure, Alexander caught me up. He had quite recovered from his indisposition and we marched on to Barh after crossing the River Saban Gidda, about $700 \mathrm{ft}$. broad and $4 \mathrm{ft}$. deep, and two days later we crossed the River Kamal, $200 \mathrm{ft}$. broad and $4 \mathrm{ft}$. deep, and a mile further on the River Zungar, $600 \mathrm{ft}$. broad and $3 \mathrm{ft}$. deep; all with the swift currents usual at this time of the year. In all probability these three rivers join and form the Kaddera, which flows into the Benue. Further on we reached Mount Zungaru, for which we had been making ever since we left Ampang. Here we parted again, as the food question had become very serious. While I climbed the mountain with a few carriers, Alexander went off to the east, to a place named Dass, where he heard that food could be got. Thence he turned south to a hill called Shell, and on the 18th arrived at the foot of Mount Zungaru with all the food which he had been able to get together.

Meantime the few carriers who had stayed with me, had had great difficulty in getting to the top of the mountain. Finally, however they managed it, climbing with their loads up ravines so precipitous that I could hardly scale them on hands and knees. Half way up, indeed, they came to a dead stop, and some of them even began to descend again, while the others tried hard to keep me from going on by 
declaring that there could not possibly be any water on the top. Previous experience had taught me, however, to pay no attention to this sort of thing, and when we eventually gained the easternmost peak, we found plenty of rainwater collected in holes in the granite rock. We were rewarded by a magnificent view in every direction, and I could see clearly not only Mount Ampang, but what I had hardly dared to hope for, the whole Murchison range at least seventy miles off. I also had the pleasure of observing our old friend Mount Madong, to which angles had been taken from Ibi. To the north loomed the big masses of Mounts Zaranda and Buli, over the other side of which I was told lay Bauchi, which was to be our next objective.

Considering how thin the soil was on the mountain, there was an extraordinary amount of vegetation, but despite the attractions of the place, with its beautiful little dells, fresh foliage and clear atmosphere, we did not pass a happy time there. None of us felt well and I had great difficulty in keeping the carriers from deserting me. I do not know whether this was on account of their terror of the evil spirits, which they declared infested the mountain, or because some injurious metallic substances had got into the water from the rocks. The nights were rainy or very cloudy, and it was nine days before enough observations could be obtained to justify me in leaving my uncomfortable post. In the middle of this Alexander arrived from his journey to Shell, but finding that I could not leave yet, went on to Kashinaua at the foot of Mount Zaranda, and from thence to Bauchi, where he visited the British Resident.

During his absence, I saw something of the other side of 
the Hausa-Pagan difficulty. The old chief of the little village of Zungar Sofo ("Zungar of the old men"), which lay at the foot of the mountain, came up and complained to me of a body of Hausas who had come down on his people and looted everything they could find. This was another example of the fact that the Pagans were not always the attacking party. For the last three or four centuries at any rate, and probably from time immemorial, the more civilised tribes and races have raided their less advanced neighbours, mostly for slaves.

On July 23 Alexander returned, suffering from an attack of fever. Meanwhile, I had succeeded in taking all necessary observations and descended to join him. He had brought with him a tremendous amount of food. I cannot imagine how he succeeded in getting it, as it is certain that the chiefs from whom he obtained it, had refused to sell to the people of Bauchi, though the latter were in such straits for food, that they would have given everything they had in exchange for it. If it had not been for the wonderful tact he showed in dealing with those who had food to sell, and his ingenuity in persuading them to part with it, it would not have been possible for me to have stayed on Mount Zungaru long enough to get observations, though these were absolutely necessary for the work. Nor could we have stayed at Bauchi the three days under which we could not have fixed its position and made the connection with Mount Buli. On his journey Alexander saw many people lying dead of starvation by the wayside. He was not well enough to go on again at once, but caught me up the next day at Babarri, near which town I came across some Cow-Fulani. 
These interesting people have kept their type pure by not mixing with any other race. They wander through the country to-day, as they have done for hundreds of years over all the Western Sudan, keeping their flocks and herds. Some of them have features very much like one of the old Egyptian types. They are rather inclined to be surly and resent questions, but show a sturdy independence, which one cannot help admiring.

On July 26 we skirted the slopes of Mount Buli and made our way to Bauchi, where we pitched our camp about a quarter of a mile south of the high city wall. Of this wellknown town I will not say anything, as it fell in the line of march of the leader of the expedition Boyd Alexander, except that it was here I obtained some little sheep-skin boxes filled with holy earth, which was supposed to have such wonderful medicinal properties, that a little of it rubbed on the forehead was believed to cure all illnesses of the head.

On the night of our arrival, a leopard carried off one of the sheep tethered just outside our tents; the cries woke me up, but it was too late to do anything. Luckily, we were soon able to complete a base for triangulation with Mount Buli, and had lovely nights for stars, so we were able to leave Bauchi on July 29-much to our relief, as it was terrible to see so many famishing people for whom we could do nothing.

We next reached Deggelli, the first Denaua town, which was perched on the top of a rocky hill. The country here, though hilly, was not very suitable for plane-tabling, so Alexander was unfortunately unable to do any more of this after Bauchi. The part he did do-from the Montoil country 
to the last named town-was as usual extremely accurate, and of the greatest service in filling up the map.

The Denaua are mostly pagan, but, as this tribe lies on one of the main trade-routes in the dominion of Bauchi, it is a more or less civilised one.

After a day's stay we went on to a hill in the distance from which we hoped to get a view of Mount Buli. As we drew near, it looked exactly like a colossal lion crouched for a spring. We arrived at its foot and pitched our tents. Alexander looked worn out and was persuaded to lie down, while I climbed up to reconnoitre. After two hours of acrobatic feats, the highest peak was reached, and to my delight, over the intervening hills, the unmistakable summit of Mount Buli was to be seen fifty miles off. Like all the other mountains which we climbed, the scenery on the top was very fine, and traces of former habitation were to be found. A somewhat unusual feature here, however, was a series of charming little ponds and near by deep, dark crevices and caverns in the rock. These, I was told, were the abode of leopards, which also abounded on the next hill.

Next morning we moved our camp to the top, by a short and easy way on which I had stumbled in descending the hill.

On August 3 Alexander had to take on most of the men and go again in search of food, which had by now run short. We arranged to meet if possible at a hill we saw in the distance, about forty miles off, which was to be our next objective. As usual, angles were taken to every hill in sight, of which there were not very many, but it was impossible to identify any of them for certain, on arriving at the next peak, 
as they had no distinguishing features, and were often hardly visible.

That night it was possible to get some stars, so we moved on next day to Gonngura, a walled Hausa and Fulani town. Unhappily the townspeople caught some of the carriers trying to steal, but were pacified when the guilty parties were flogged before the headmen of the place. This was the only time in which any of the carriers misbehaved themselves in such a way.

Almost the whole of the next day was occupied in crossing the River Gongola, which is here about half a mile wide, very swift and deep in places at this time of the year. Transporting the carriers and goods was a long business, as everything had to be got over in two crazy dug-outs and one of my horses had a narrow escape from drowning on the way. We started at 8 A.M. and it was 5 P.M. before the last load had been safely landed on the other side.

We had now reached Gombe territory, in which the walled towns were full of Fulani, for whom many Pagans were working in the fields. After a night at Golo, we went on next morning to Gombe itself, the seat of the ruler of the whole territory. The Emir came to see me with an immense court, among whom were some great officials, distinguished by the swords of state which were carried before them. He took off his sandals, in the ordinary salutation to a white man, before approaching, and then sat down with great dignity on the only seat of state I had to offer-namely my best valise. The carriers did not get on well with the people of these towns. They complained that the Fulani were too conceited to have anything to do with them, or, as they 


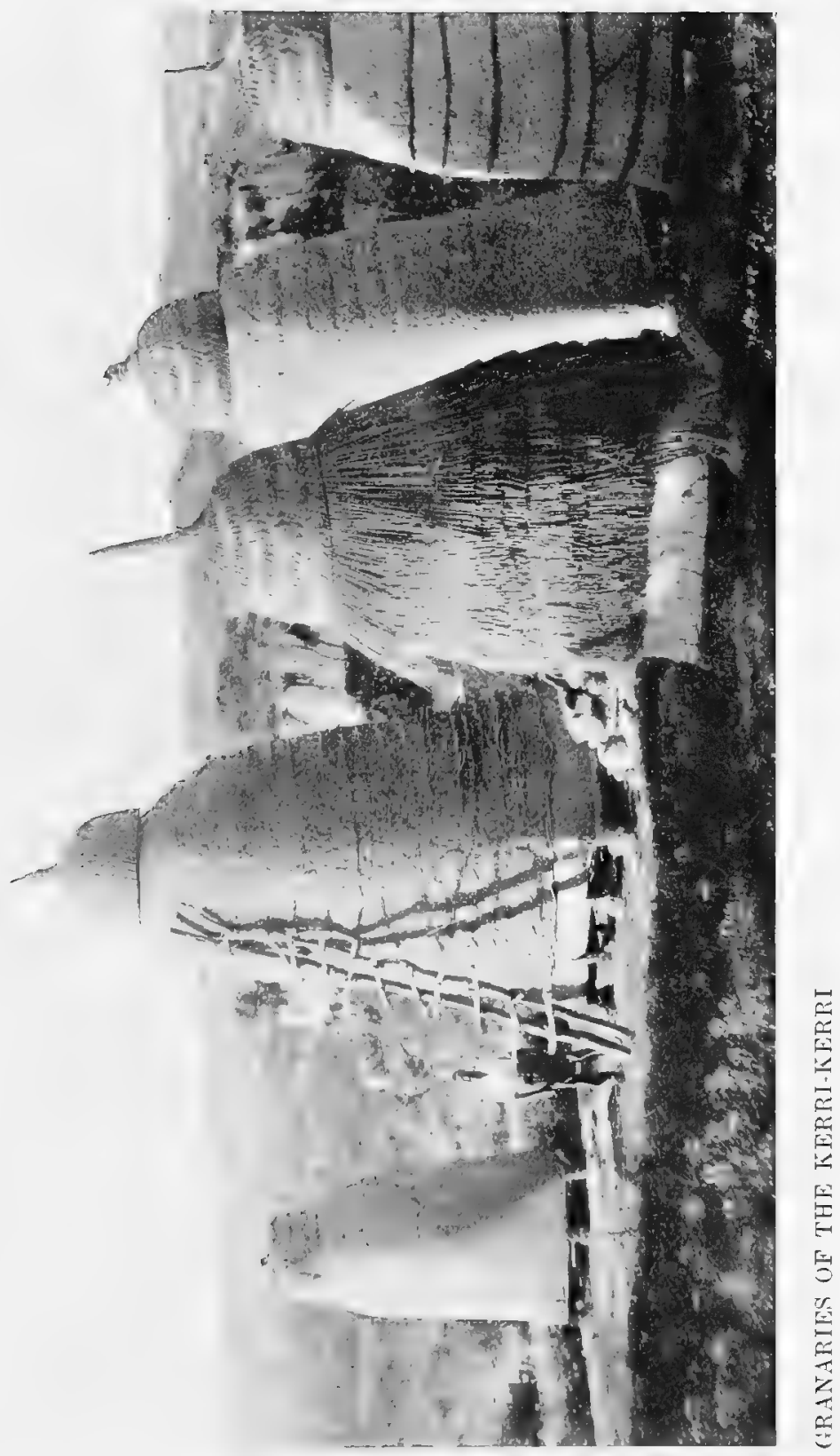



phrased it, "had too big bellies." Some of the Emirs and chiefs have quite grand palaces, the architecture of which, especially of the entrance gates, reminds one, to a certain extent, of that of Ancient Egypt, though Fulani buildings are only made of wood and mud, or in some rare cases of sun-dried bricks.

After anxious inquiries, it turned out that there was a hill a little further on, called Kalam, which seemed to me to be that of which I was in search. We went on accordingly and camped at its foot.

All this time nothing had been heard of Alexander, but at last news came that a white man was not far off, on the other side of the Gongola. A messenger was at once sent, who returned with a note from him to say that he would join me next morning. This he did, and from the top of Mount Kalam along the horizon, about thirty-five to forty miles off, we saw some curious peaks in the direction which we wanted to follow. After a day's rest Alexander went off again with the greater part of the carriers to recross the Gongola, which is here narrower than at Golo, but very swift and deep. That night he stopped at Zoni, and then went on to Alia, where, after having finished my observations, we met again on August 10.

During the time he had been away from me, he had made a long march to Darasso and then on to Kalam, with another large supply of much needed food. While lunching at Alia, a Kanuri girl, who was very pretty, rushed up and implored help. She had been captured by Rabeh, and sent by him as a slave, like many others to a tribe of their enemies. This Rabeh was, of course, the famous freebooter, who from a 
slave had risen to be the sultan of one of the most powerful States in the Sudan.

On each cheek the girl, who we afterwards found was called Fatuma, bore the three little cuts which he caused to be made as a sign of ownership on every prisoner whom he captured, besides the five or six longer marks down the side of each cheek, parallel with the ear, the distinguishing sign of most Beri-Beri as the Hausa call them, or Kanuri as they call themselves. After her there rushed a huge brute, who claimed her as his property and threatened her with dire punishment for having tried to escape from him. The girl's terror was so evident that Alexander felt he could not leave her to the mercy of such a man, so he bought her for five pieces of cloth and gave her permission to travel with the carriers' wives to her own country to which we were going. The reason that so many women accompanied the expedition was a practical rather than a sentimental one. While the husbands carried our baggage, the wives carried theirs and also prepared their food. Fatuma afterwards told us that there were ten other Kanuri girls, gagged and bound at this town, but she was the only one who managed to escape to us.

After an eight hours' waterless march, mostly through bush, we reached some most extraordinary country belonging to the pagan Kerri-Kerri. It is only necessary to describe one bit of this, as it will be found typical of all the rest.

Amid an alluvial plain one sees a huge circular mass of chalk with precipitous cliffs stretching sheer up on every side. At the top, 100 to $500 \mathrm{ft}$. above the plain, the mass forms an absolutely level plateau crowded with villages. 


\section{THE SURVEY CONTINUED}

In the midst of this space rises a very steep peak of ironstone or laterite which, for about $50 \mathrm{ft}$., mounts by huge steps or terraces straight as the wall of a house. In the first terrace

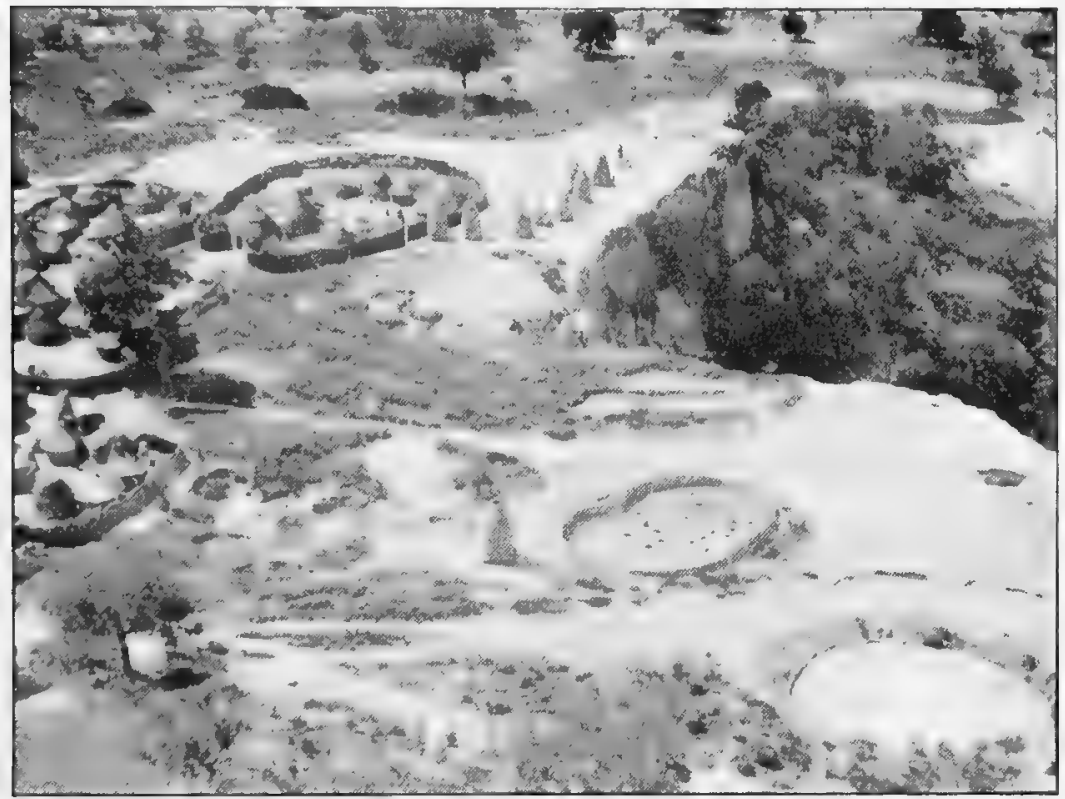

A KERRI-KERRI TOWN

a series of deep narrow wells has been dug. These, which completely encircle the peak at a distance of ten yards or so from one another, are only about 2 to $4 \mathrm{ft}$. across. Unless they are very deep, the water in them must be above the level of the villages on the plateau below. From the top of the peak a most extraordinary sight presents itself. One looks down on to the plateau and sees clusters of hamlets, each surrounded by a little wall of matting. Among them, and particularly along the edge of the cliff, are curious mud granaries, somewhat the shape of an elongated beehive 
and covered with a neatly plaited straw cap to keep out rain. Some of the granaries are covered from top to bottom with frills or flounces of straw. They are all raised above the ground on wooden bases like hayricks or corn-stacks in England, and their height varies from 10 to $20 \mathrm{ft}$. The grain is extracted by a boy, who climbs up a ladder on the outside, takes off the cap and, jumping in, passes out the corn to men who have mounted to receive it. When the supply is growing low, a hole is made in the bottom of the granary and the grain drawn out. Scattered over the plateau are ponds of water which we were told never dry up: but this is so chalky that it can only be used for washing. This chalk was a great surprise to us, as it was the first formation, other than belonging to the igneous rocks, which we had seen out there. A considerable number of dyeing pits are also to be seen.

Alexander, who was at the head, was the first to climb up by the only way of ascent which he could discover to these otherwise impregnable strongholds - a kind of chimney crevice in which zigzag steps had been cut. At the moment when the accompanying photograph was taken, in which one can just see the foremost carriers like ants on the face of the cliff, he was forcing the barricade at the top, though at the time I, of course, did not know this. The natives made no further opposition for the moment, after their barricade had been cut through and we all reached the plateau in safety. As we were debating, however, as to the best spot for our tents, some of the carriers came rushing up, and we saw that a number of the Kerri-Kerri had gathered on the lower terraces of the peak and were throwing great 


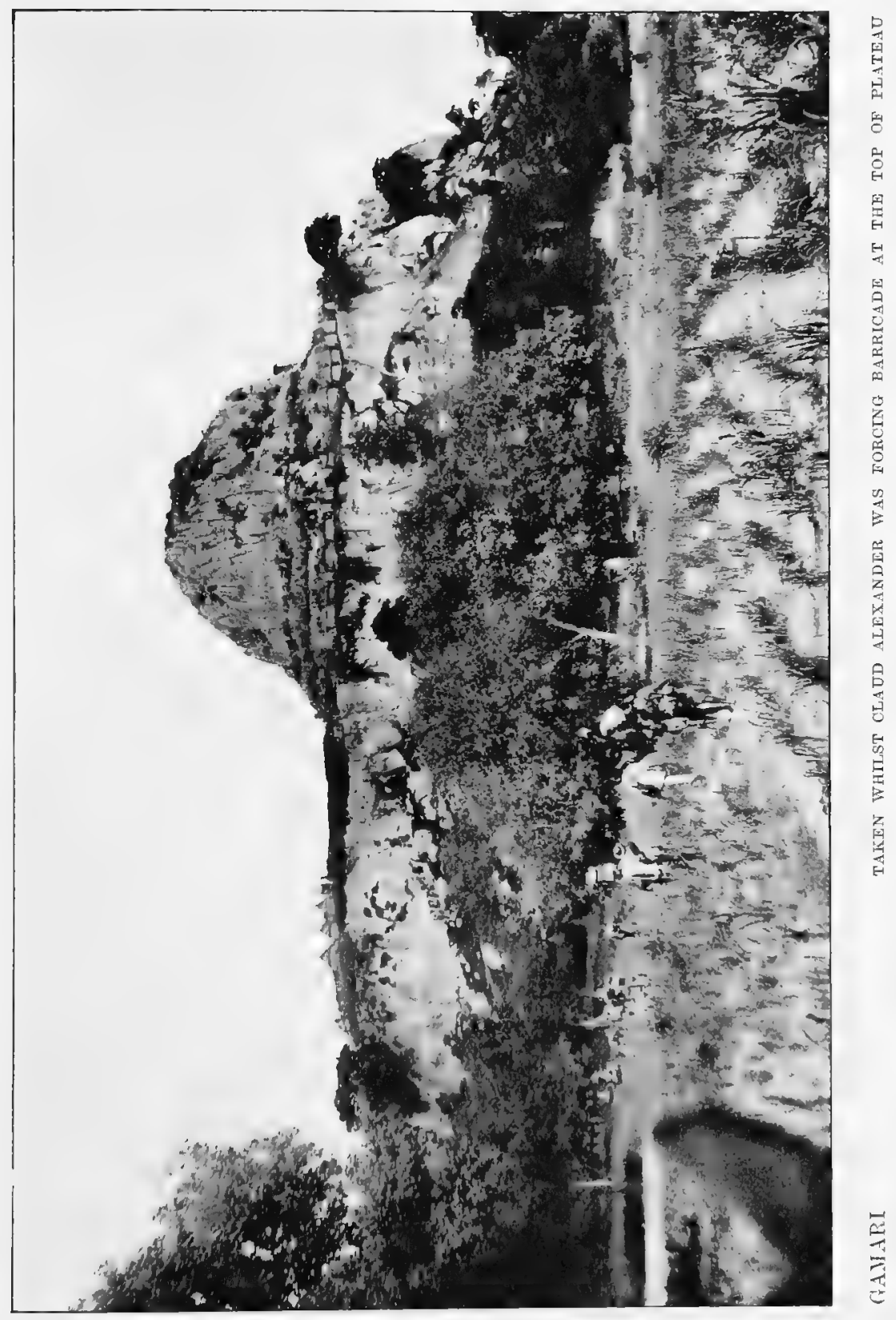



stones and pieces of rock alt our carriers in one of the villages behow. I was just in time to preserent the sulders from firing

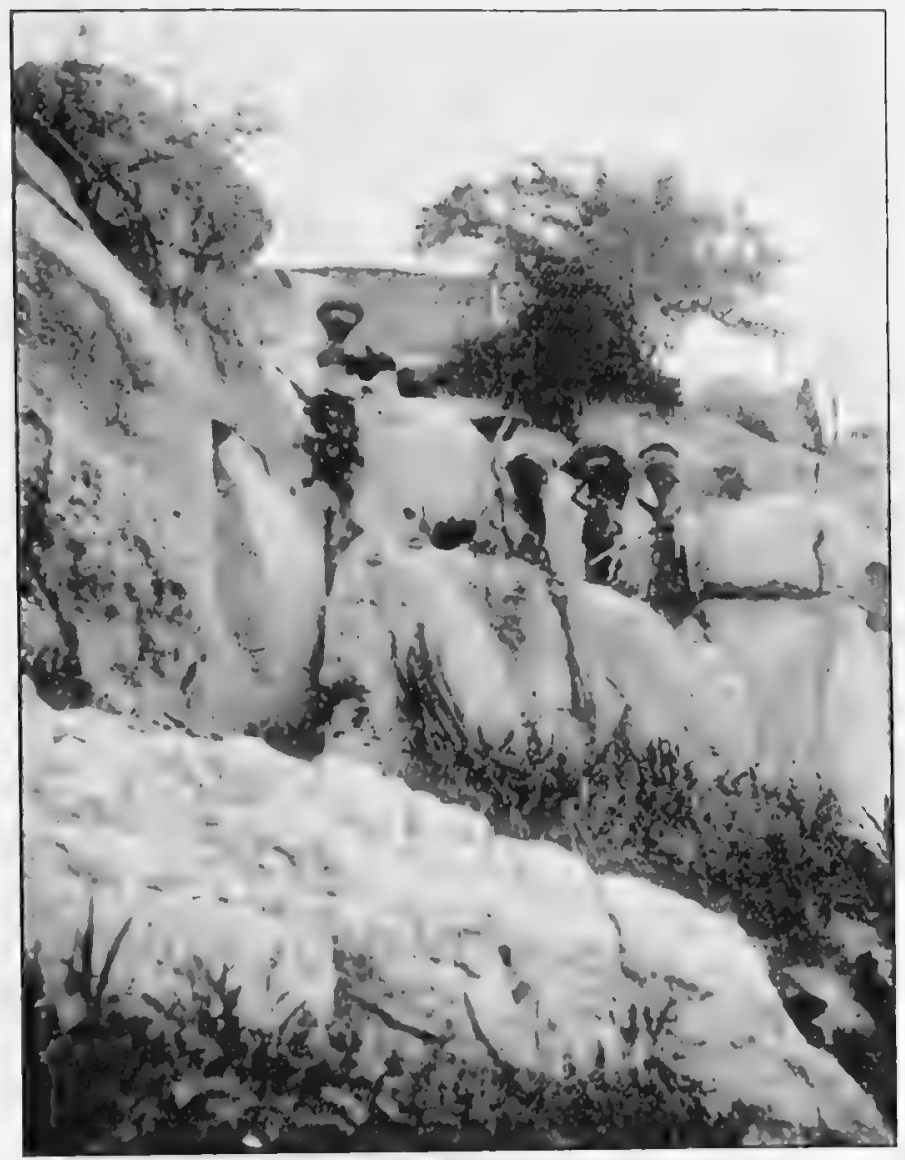

ASCENDING A KERRI-KERRI FLATEAU

at the natives, hundreds of whom were now brandishing their spears and yelling war-cries. An arrow whizzed just by one of the men as I came up. Alexander, who had had the presence of mind to gor and get his rille, now appeared, and with some difficulty and mulh gesticulation the inter- 
preter explained our pacific intentions. Finally they quieted down, the chief came in and within half an hour's time carriers and Kerri-Kerri were hobnobbing together as if they had known one another for years. We were very glad the affair had turned out so well, as the natives were at bay on the hill, with their wives and children behind them and no place for retreat. Had there been a fight, one side or the other would probably have been exterminated.

A little later a girl, with wrists and ankles joined by fetters, came hobbling or rather hopping up and begged to be freed. We found that her history was much the same as that of the girl at Alia, and as the chief to whom she belonged was very glad to exchange her for some cloth, she also joined the carriers' ladies-and in course of time captivated the heart of one of the headmen. So friendly had our hosts become before we left them, that they volunteered to show us on our departure an easier way down to the plain below. Even this route, however, was somewhat rugged, as can be seen from the accompanying photograph.

As a rule the Kerri-Kerri are a tall slim race, and, like most Northern Nigerian tribes, have not very much of the negro strain in them. They wear fine clothes made from native cloth and are very good metal-workers. Their swords have not the handsome scabbards of the Kanuri and Hausa, but the blades are finely engraved. These are of a curious shape, thick along the mid-rib and tapering to an edge on each side. The designs on them are generally composed of lines of dots, diamonds and veined leaves.

From their own accounts they have lived on these strange 


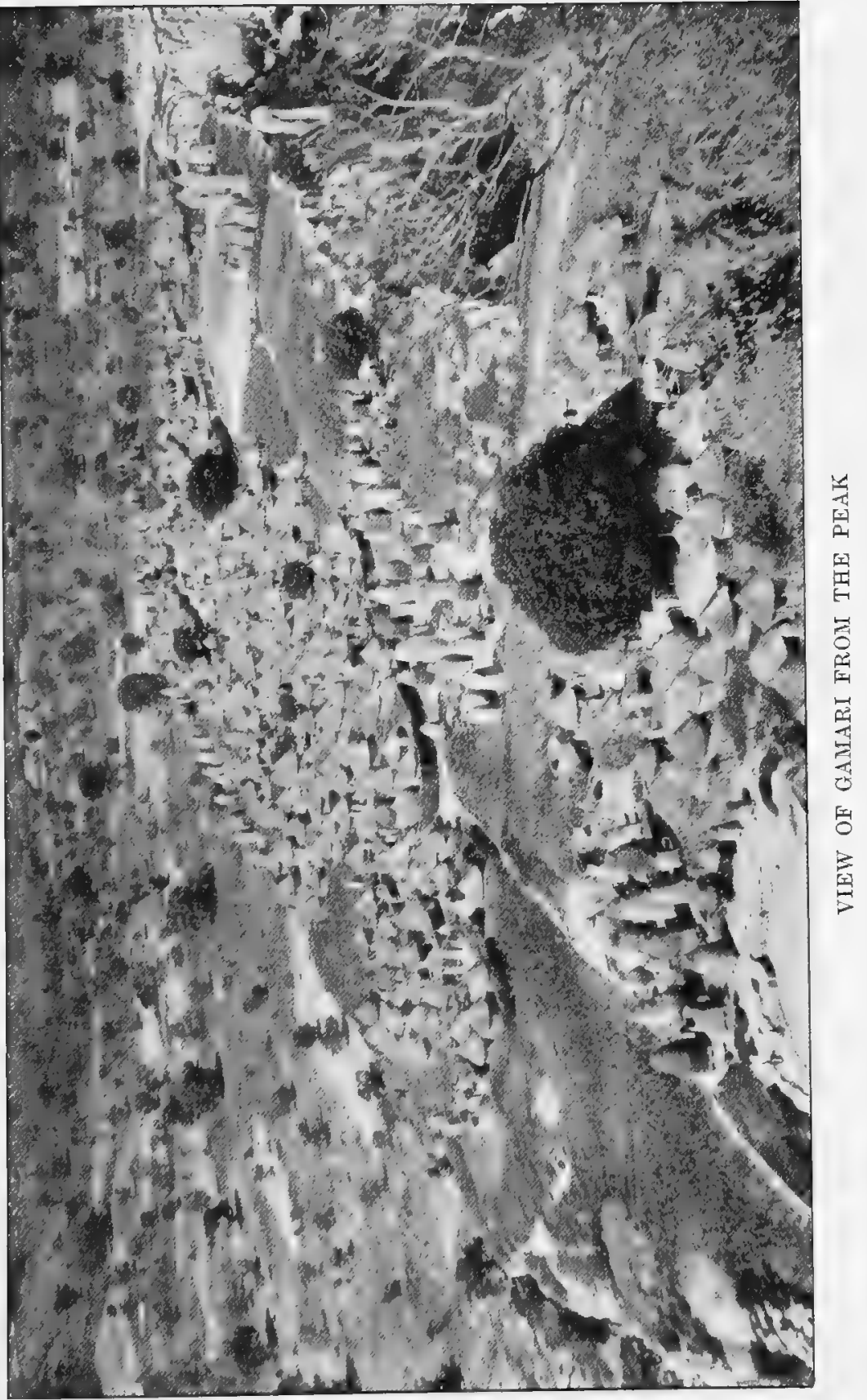



strongholds from time immemorial. No tradition of an older race, dispossessed by them, has come down, and indeed it would have been difficult to imagine a more impregnable fortress. To our great surprise we noticed several ponies, and when we asked how they could possibly have been got to such a spot, the natives naïvely answered, "Born there," a reply which left us little wiser as it did not explain how their ancestors could have been got up. The general idea seemed to be that, at the beginning of all things, these places of refuge had been provided by the tribal gods for the special use of the Kerri-Kerri, whose ancestors had been gently deposited there with their cattle by the same benign agency, and that they had remained there in peace and security ever since.

The crops were cultivated on the alluvial plain below, but a six months' supply of food was always kept, in the granaries already described. Even this plain, however, was well protected, as we found it honeycombed with deep trenches, so well covered with leaves and thin branches as to make them quite invisible to any one even on the brink. These were specially designed as a protection against the invading cavalry of Bornu, and were so intricate that it was necessary to follow our guides exactly to avoid falling into them.

Next day, August 12, we left Gamari, as the place was called, and went to Lewe, another Kerri-Kerri stronghold of almost identical formation; except that at the top of the central peak a small plateau of about $200 \mathrm{ft}$. square was to be found, on which a few stunted shrubs managed to find a foothold. Alexander stopped behind on Gamari for a few 
hours to put up a subtense for me to observe to from Lewe. The carriers bore my tent right up to the plateau on top of the peak, though I could not imagine how they did it, as I had great difficulty in getting up myself without any encumbrances. While taking angles to Gamari, I was interrupted by a sudden uproar from the villages below. Running to the edge of the peak, I saw the carriers, who had now returned. to the plateau below, in a huddled group surrounded by a posse of Kerri-Kerri shouting and brandishing their spears. They were saying that if the white man wanted food he would have to fight for it. After shouting a few explanations from my post of vantage and offering very good pay, the king promised to go and see about it, for which compliance I afterwards found that he was ignominiously beaten by his people. Two hours later Alexander arrived and told me that some poisoned arrows had been fired at his party from the plateau. The people, however, soon quieted down and we became as good friends with them as with their neighbours at Gamari. On returning to my tent, I found that hosts of white ants were destroying its contents and everything except the instruments had to be hurriedly carried down again.

Looking northwards, we could not see many more examples of the exact formation of the two stopping-places last described. There seemed to be a series of chalk plateaux stretching for miles, and rising out of these long parallel ridges of crumbling igneous rock, instead of the one central peak as at Gamari and Lewe. There was not a single point to which one could observe, and so far as we could judgehad we gone straight ahead and then taken an azimuth back 


\section{THE SURVEY CONTINUED}

-we should not have been able to take any azimuth forward. We therefore decided to double back to a hill which we saw in the south-east on the other side of the Gongola. Another inducement to do this was the fact that our food had given out, and that for the last five weeks we had been practically living on the country, a course which was not very satisfactory to European taste.

At Ashaka on the Gongola we hoped to find Gosling with the steel boats and the main body of the stores, from which we could refit. The stock of cloth, which was the principal article of barter, had also nearly run out. So, on August 14, I left for the Gongola, and, after a long march through bush country, arrived at Baruo on the other side of the river just as darkness was setting in.

Alexander, who had been making a great effort to get a large supply of food for the carriers, arrived too late to cross the river that night. We had heard that a very severe famine was raging in the neighbourhood, so it was necessary to get a stock of provisions to carry us through. Some of the Kerri-Kerri had refused to sell anything, but from others he got a fair supply.

On August 15 we had an interesting march to the town of Biri, through a thick bush country between two rows of hills, and next day reached Bagi, the principal Fulani town of the district. It lies at the foot of the hill for which we had been aiming since Lewe. My tent was taken to the top, to which Alexander accompanied me, but, as he thought it wiser to camp with the carriers, he had to go down again in the dark, which was a difficult and dangerous feat. The spot from which we made our observations was on the edge 
of a cliff, which fell 700 or $800 \mathrm{ft}$. sheer beneath us. From this point we got a splendid bird's-eye view of the country, and especially of the whole curve of the Gongola. As there were no very convenient hills to the north or north-west, and as we wanted to get more to the east before striking up through Bornu, it was decided to make for a curious needle peak, which we saw in the south-east. So, in the afternoon, we determined to push on to Ashaka, but against this the carriers struck. Chiefly because they had been doing long marches lately, often climbing hills, and probably were somewhat tired; but partly, no doubt, because they thought they had us in their power, and that we could not get on without them. When they found out that we were going to put our beds and tents on three donkeys which Alexander got from the chief of the village, and were told that we would bring back oxen for the rest of the goods, and let them go-they soon gave in. Alexander thought it necessary to give them a lesson, so we started from Bagi that night at 6.30 P.M., and arrived at Ashaka at 1 A.M. It was pouring all the time. The night was pitch dark and we did not know the way at all. The road was so bad that it would have been difficult by daylight, and nothing surprised me more than the way my horse kept his footing the whole time-stepping gaily down gullies, and picking his way through swamaps. When we came to the first village, the carriers and soldiers thought that they would have their revenge and so persuaded the guide to run away. We did not suspect them at first, but when we found that the two succeeding guides behaved in the same manner, although put under charge of two soldiers, we saw that something 
must be amiss. I therefore kept the next guide close to my horse at the head of the procession, and we managed to arrive at our destination. Here we found José Lopes, who had got up all the stores after great difficulties and against a tremendous current and rapids. 


\section{CHAPTER VI}

THE SURVEX CON IINUED TO MAIFONI

(Written by .HT. P.A. Talbot)

$\mathrm{WE}$ were now in a land of plenty, for besides the stores there was plenty of fresh milk and vegetables, such as a kind of pumpkin, the rind of which when old forms calabashesbut which, when young, tastes almost like vegetable marrow. There were also nuts, some of which tasted very like broad beans, others like small sweet potatoes. By the river grew a great many date-trees, though their fruit was not yet ripe, and a sort of wild spinach abounded.

Alexander's talent in the arrangement of menus now shone forth with particular brilliancy, though it was perhaps more remarkable and the more appreciated in times of dearth, when he succeeded in getting the cooks to make, under his orders, tasty dishes out of the commonest and scantiest ingredients.

Alexander now decided to go by the main road to Gujba, where he wanted to see the Resident and arrange about the transport of the boats and goods to the Yo river. I was, in the meantime, to go to the needle-point peak which we had seen from Bagi Hill, and thence if possible towards Gujba, to meet him.

With about twenty carriers and three soldiers I left for Gulani, a town said to lie south-east of Ashaka, and therefore 
probably near the hill I was in search of. After scrambling through a deep swamp we emerged into a palm forest thickly tenanted by baboons. These were enormous, some of them

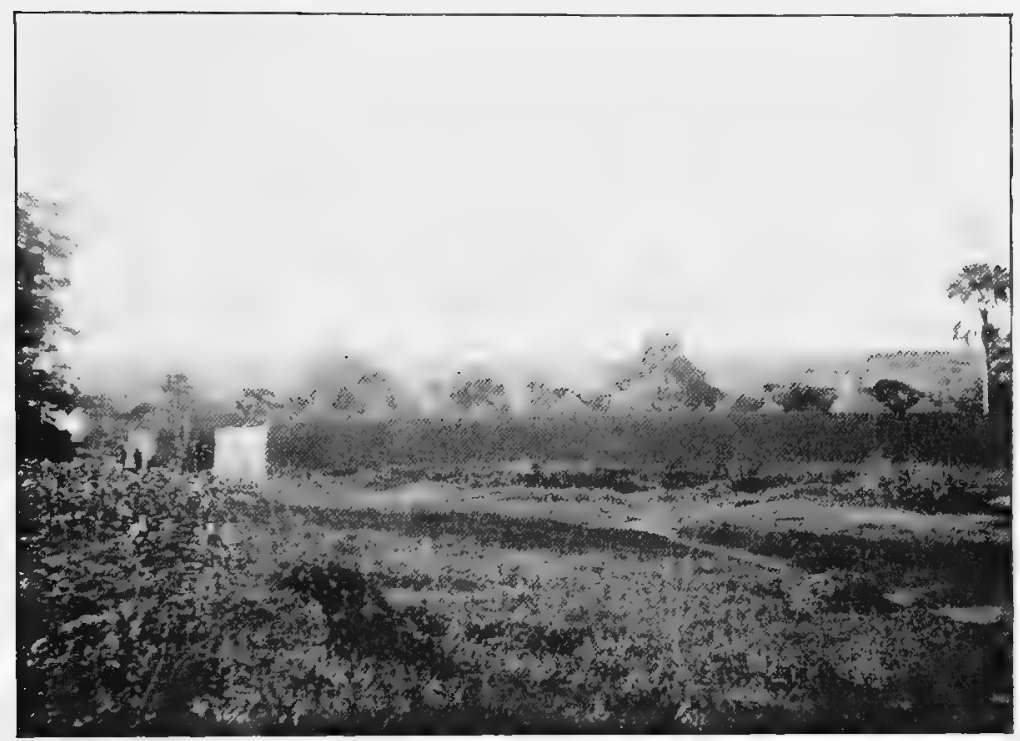

$\triangle$ BARBURR TOWN

over $5 \mathrm{ft}$. high and with very thick dark grey or brown fur. They always saw or heard me coming, as I could not get through the thick grass which was here $3 \mathrm{ft}$. high without making a noise, especially as the going was not at all easy, owing to big holes which they had dug at the bottom of most of the palm-trees to get at the young roots. Most of these holes were already overgrown with grass, and could not be seen. Over and over again one of the apes would climb a tree in the distance to see if I was still following, and then go on to another tree further off-though before my first shot they had let me get quite near. They seemed to go about in 
families. One lot that I followed for some time consisted of father, mother, and three young ones. Part of the time they walked upright and once appeared to be hand in hand. They made a noise like the deep bark of a big dog.

Gulani is a very strongly fortified town with two deep trenches and a thick wall pierced with loopholes. Except for one or two posterns, there is no way of getting into it but through a gate, the approach to which is built on piles which could easily be burnt down on an emergency. Close by on a hill to the south stands Bajogum, another town belonging to the same king, which is, if possible, even more strongly fortified.

From now onward all the country as far as Kwong belongs to the Barburr, who, next to the Kerri-Kerri, are perhaps the most interesting people out here. The name, Barburr, was given me by Alexander, when he met me at Burutohai. Up till then I had been told that their name was Habe. This word, however, is simply the Hausa expression meaning "bush people," and, on further investigation, I found that Alexander was quite right, and that among themselves they only go by the name he gave. The higher classes are usually Mahomedan, but the old pagan customs still obtain among the mass of the people. All their towns are walled and surrounded by a trench, and they told me that before the coming of the Fulani their territories extended far beyond their present limits. One place that they mentioned as having been formerly possessed by them was Bagi, and they asserted that when the Fulani attacked some of their people, the latter retired up the mountain, and certainly I had noticed traces of former habitation on Bagi Hill. 
With very few exceptions the Barburr towns showed me more hospitality than any others in Northern Nigeria. They wanted to load me with presents and were most helpful and

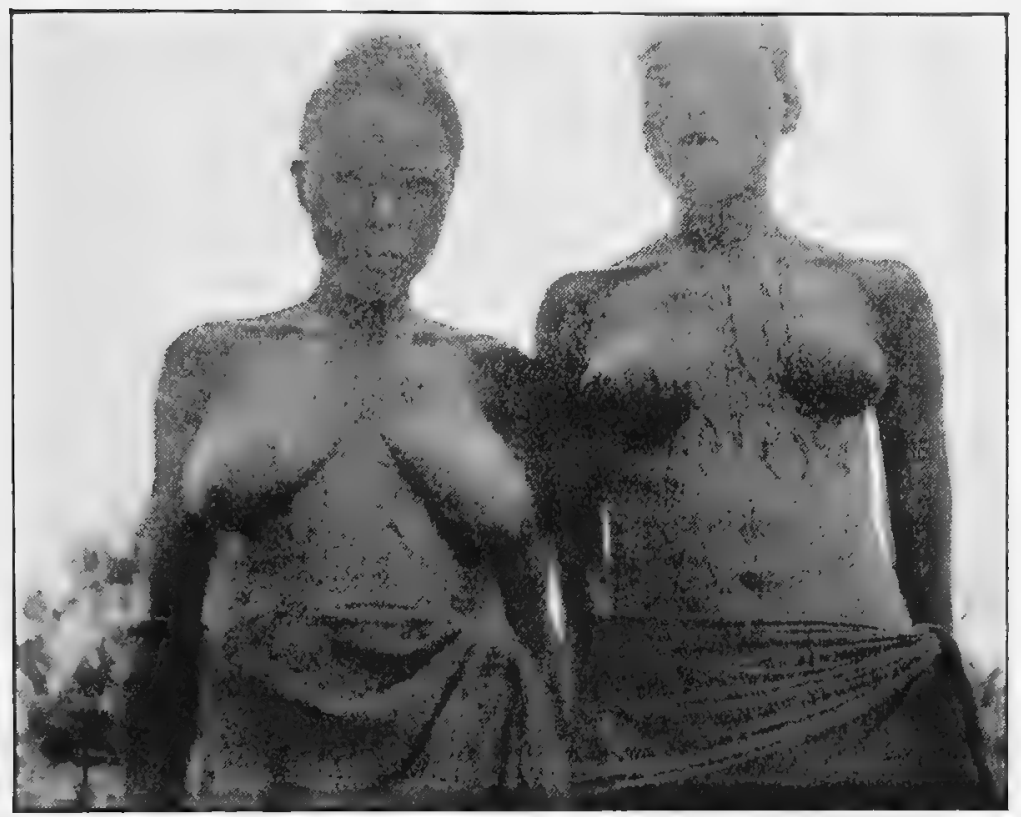

BARBURR GIRLS AT KWAIA

kind in every way. The King of Gulani seemed almost pitiably afraid of the white man at first, and there was great excitement in the evening when the theodolite was set up in order to take observations of the stars. Probably it was owing to my fame as a Juju man, caused by this sight, that such a good reception was given to me by the rest of the Barburr towns. It was a great pleasure to see from near this place Mount Zogabi, the peak for which we were making.

When going out as usual to shoot something for supper, at a town called Pupa I had great difficulty in preventing 
the whole village from following me. They had evidently heard of the white man's gun, but never seen one before. As a great favour three men were allowed to come with me to point out where the best game was to be found. There was a tremendous commotion when two guinea-fowl fell to a shot. Indeed, one of the men capered about to such an extent in his excitement, that I was really afraid he was going to have an attack of hysterics. This, to them a wonderful feat, coupled with the reputation as a Juju man, which had preceded me from Gulani, probably induced the chief of this town to give me two of my greatest treasures, one a small iron tube with a focussing arrangement at the end, which they used like a telescope for watching the paths or distant points from which they feared the approach of enemies. Although without a lens, it certainly is useful for this purpose in the blinding glare of the tropics, and I am assured that this is the only case known of a primitive tribe possessing such an instrument. My other treasure which it was very good of the chief to give me, as I could see it almost broke his heart to part with it, was a twisted iron snake, about 15 in. long, which he said was hundreds of years old and this has since been corroborated by authorities at home. He also said that it was a "great magic" and had the power of keeping its possessor perpetually young.

Leaving this place we went on to Kwaia, which is not far from Mount Zogabi. Kwaia is quite a big place and its women are unusually pretty, but whenever I wanted to take a photograph the men hurried the pretty ones off, and only left very plain specimens for the camera. Some of the women were elaborately tattoed, or rather incised. The 


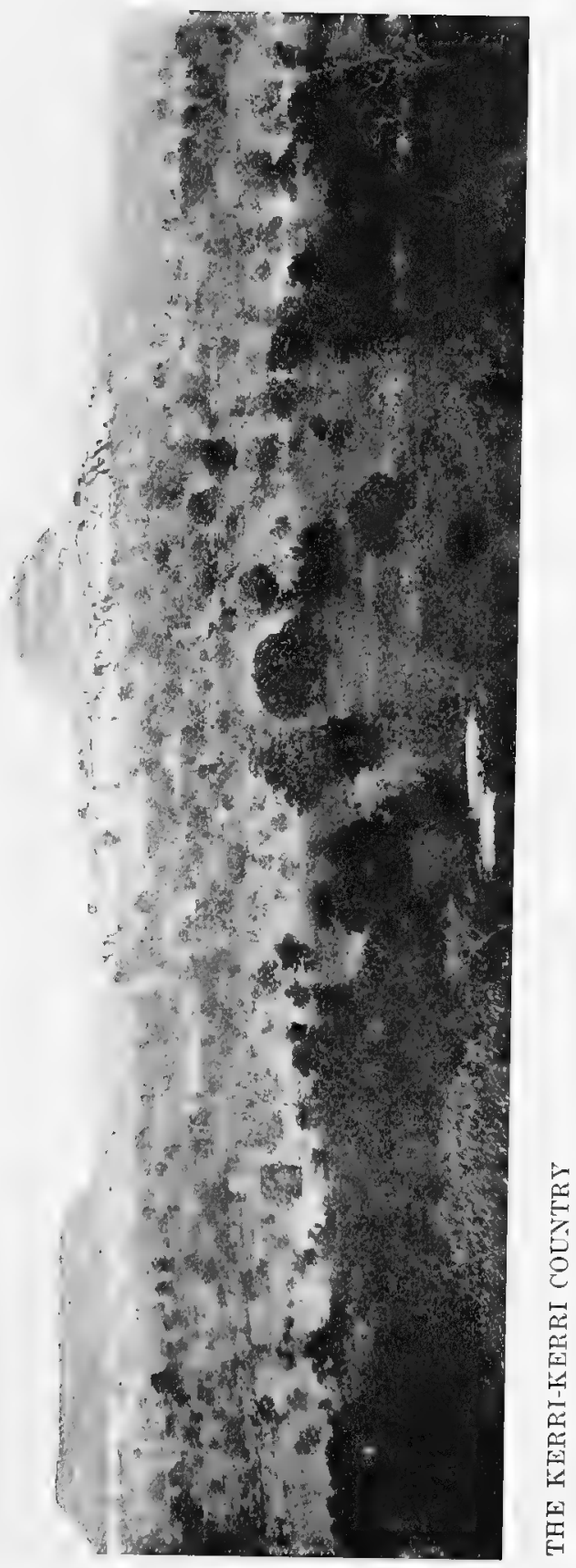



children were charming all over Northern Nigeria, but here they seemed to me specially so.

August 23 was spent on the top of Mount Zogabi, the needle-like peak which we had seen from Mount Bagi. This was our stiffest climb during the whole expedition, and it was a wonder to me how the theodolite could possibly have been got up the last bit. From here we had the best view of all. To the north lay a series of hills, one of which would do very well for our next station. To the east could be seen hills near the German border, and to the south, not far from where the Benue must have been, was a mountain which could never be mistaken by any one who had once seen it. It was like a candle, hundreds of feet high, springing from a still higher tall straight rimless candlestick. Not far off to the east, was a hill shaped like the dome of St. Paul's Cathedral. Flowing past, to the south of Mount Zogabi, in the direction of the Gongola, was what seemed to be a fairly big river, called by the guide the Jaui river. The latitude of the hill was got by a subtense to Kwaia.

Next day we moved on again, getting to the small town of Gurrbilla in the afternoon. Here the people did all they could to persuade me from going on to the proposed mountain. They said that it was a terrible place, the haunt of very malignant spirits, and that there was no way of reaching it, save through bush, rivers, and bad ground. Certainly this latter statement was more or less true, though the way was not so bad as some of the routes we had lately followed.

On the way we had to cross a rather narrow river, only about a hundred feet wide, but so swift that one could hardly stand in it, even when only up to one's waist. After 
swimming about in it for some time, or rather being carried down by the current, we managed to find a ford. Here, most of us joined hands to make a line across the river, and by holding to this human barrier, the women and loads were passed over. Before we found the ford, my boy had succeeding in getting more than half way across, carrying the clothes which I had had to discard. . Even when he at length went down he still bravely held these above the water, though his head was underneath. Going to his assistance we both went under, and this time the clothes went with us. To show the great variation in volume of these rivers, it may be well to mention that, when Alexander crossed it two or three days later, he found a more or less placid stream only up to his knees.

About four o'clock we reached the foot of the hill and camped for the night, fortunately finding water in puddles. Next morning we started to climb. About half way I feared that the carriers would be falling with their loads and perhaps breaking their necks, and that it would be necessary to send everything back except the theodolite. They all got up, however, telling me that they were strong because they had had "plenty chop."

From the side facing me the hill looked like a flattened cone, rising almost sheer to the summit, symmetrically ribbed from top to bottom with bevelled lava ridges, separated from one another by regularly placed ravines; much like the ribs of a half-opened Japanese sunshade. The lava stream had evidently welled over the lip of the crater, at about equal intervals. The ridge itself was so sharp that there was only about $10 \mathrm{ft}$. between my tent and a precipice 
on one side, while it almost overhung a steep slope on the other. This ridge was the only remaining part of the crater lip, which had entirely broken down elsewhere. (In the

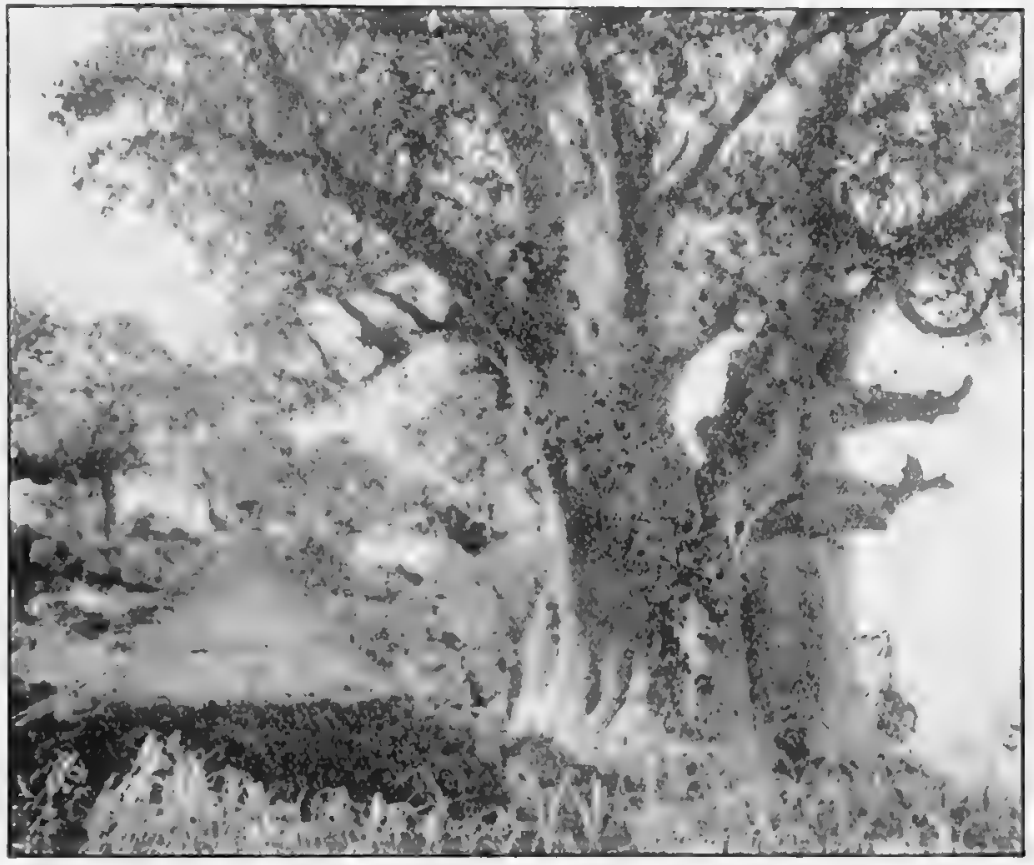

A BAOBAB TREE

further side, the hill descended almost as steeply till about half way, where it broadened into a circular platealu with a little lake from which it again fell in a rapid slope to the plain below. One or two personal attendants stayed with me on the ridge for the five day's necessary to complete observations, while the others went down to the foot. Up there we had some uncumfortable moments, as a tornado raged every day from the north, and I wals continually expecting the tent and its occupant to be blown over the other side. 
Luckily it was here possible to observe to most of the hills which had been visible from Mount Zogabi, though to the north there were practically none, and all that could be done in this direction was to observe to a low hill which was just visible on the horizon. On the way down one of the carriers let fall the theodolite, which, though badly broken, was yet not so much damaged as might have been expected considering that it fell from rock to rock for about $800 \mathrm{ft}$. The survey work would thus have been brought to an abrupt conclusion, if the leader of the Expedition had not had the forethought to take out a reserve theodolite.

The carriers below in the meantime had been in straits about food. From Kwong, the first Kanuri town, some way off, came back not only a refusal to sell but a most insulting message. But the attitude of the King changed however on our arrival when we could no longer be considered at a safe distance. He hurried to forestall any punishment, which he feared might be meted out to him for his insolent message, by sending in a present of ten sheep for which he refused any payment.

On the road to Kwong the path was lined with baobab trees of such tremendous girth that the one measuring $57 \mathrm{ft}$. at Gital would have seemed a mere baby in comparison with these giants. We also passed great fields of indigo which was being gathered into huge heaps on either side of our path.

Outside Kwong were a great many dyeing-pits, each covered with its little removable thatched roof. The inhabitants of this town are very wealthy. They possess great flocks of sheep and goats, and many clothes, and therefore 
looked down with the scorn of true Mahomedans on their poorer pagan neighbours, the Barburr, though from our

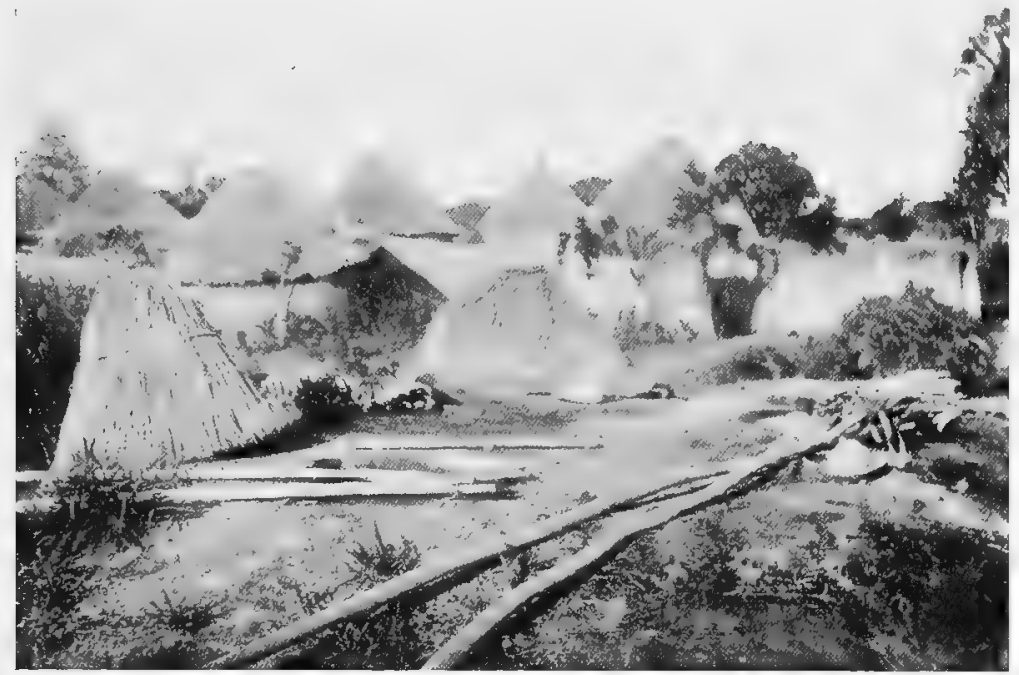

DIELNG-PITS AT KWONG

experience we found the latter more truthful and charming in every way.

Early on the morning of the 31 st a runner came in from Alexander; he had met two men whom I had sent off to Gujba with the broken theodolite and a letter, and had thus heard of my whereabouts. I at once rode back to him at Burutohai and found that he had heard so many contradictory rumours as to where I was, that he had not known where to look for me. The sad truth was now mutually revealed that on both sides provisions had given out, owing to the fact that he had not expected to be so long in finding me; and also because he thought that before now I should have worked round in the direction of Gujba, where the 
reserve stock of provisions was. He found it necessary therefore to return thither to arrange about the transport of the main body of the baggage to the River Yo, and promised to send me out some provisions as soon as he got there. I told him the general direction which I expected to follow and he said he would meet me again as soon as possible. He was not feeling at all well and was looking wretchedly worn, so, after great persuasion, he agreed to have one day's rest at Burutohai, though he absolutely refused to let me stay and look after him as I should have liked to do. Before leaving him, he told me that after he had left Ashaka he had caught a "boy" looting a village. This turned out to be one who had been dismissed by Gosling. His method of procedure was as follows: He had somehow or other got possession of a letter, and this he showed to the chiefs of the towns he came across as his warrant from the white men. He then demanded four or five goats which he said he was ordered to take to his masters. So successful had been this ruse, that he was driving quite a large flock of animals before him, when Alexander caught him and put a sudden stop to the fortune which he had been in the way of making by this nefarious practice. There is no doubt that this sort of thing is carried on to a large extent, especially by interpreters when away from supervision.

On September 3 we entered Bulabull, the first Marragi town, and at length arrived at Auma, which like all Marragi towns was a collection of small hamlets without any walls. It now turned out that what I had taken for hills at Mount Taunza were merely low plateaux covered with trees, through which the only way of getting would have been by a rigorous 
traverse, that would have taken too much time. There was no point ahead to take to, only a level plain, so it seemed best to go further toward the east to see if there was any other way of overcoming this difficulty.

The carriers and soldiers were accordingly sent on to the town of Ndivva, which was said to lie in that direction, while I reconnoitred the country round. From a low hill not far from Ndivva it was possible to take angles both back to Taunza and to a hill a few miles further on to the north. On rejoining the carriers I found them in a rather frightened group. They explained that the natives were very hostile and had forced them to pitch my tent on a refuse heap outside the town. My horse-boys also complained that on the march some Marragi had jumped out upon them, and would have killed them and stolen the horses if the soldiers had not come up in the nick of time. The chief had gone away, leaving word that he did not wish to see the white man, but the former king, who had been driven out by the present ruler, came up and behaved fairly well, though the people were all hostile and unwilling to sell any food. The soldiers, who accompanied the ex-king in search of provisions, were beaten, and on asking why they had submitted to this, they answered that it was because I had given such strict orders against firing. Of course, it was impossible to submit to such treatment, so my tent was removed and put up again in a more healthy locality and the people were warned against any further ill-treatment of the party.

On the morrow we went back to the hill from which Mount Taunza was to be seen. During this short march some of the carriers were shot at, but fortunately no one was 
hit. Next day, after leaving subtense flags there, we passed through Ndivva again, where I found that the three biggest of the nine sheep left in charge of the ex-king had been stolen. As he was responsible for them, he was told to recover them at once. We then continued our march for three or four miles to a hill to the north, where the rest of the day was spent in trying to find a suitable place for observation, and also in a fruitless endeavour to pick up the points of the subtense flags, placed near Ndivva that morning, but which it turned out had been removed by the natives directly after my back was turned. This hill, like many of the others around, was one mass of iron-ore, which was evidently much worked. Some smelting-works were to be seen below the hill, but there was unfortunately no time to visit them.

That evening at the little village of Abila near by, a visit was paid me by an imposing cavalcade of Kanuri. Their leader introduced himself as the Kachella Bukar Kago, the representative of the Shehu or Sultan of Bornu in this part of his dominions. They had come towards this quarter of the country to collect taxes, but had not cared to venture among the Marragi until they heard that a white man was there. The Shehu is in the habit of farming out the taxes of certain parts of his dominions to some of his principal chiefs, who collect what they can and pay him a certain percentage. The Marragi had refused to pay taxes for several years now and even to let a Kanuri go among them. The Kachella rode a black horse with gay trappings, and the two together made a splendid picture. The horsemen who attended him were also very imposing. Their horses wore an arrowproof head-dress, which in the sun looked as if made of plates 
of silver ornamented with golden bosses. It was really made of a mixture of metals-principally tin, decorated

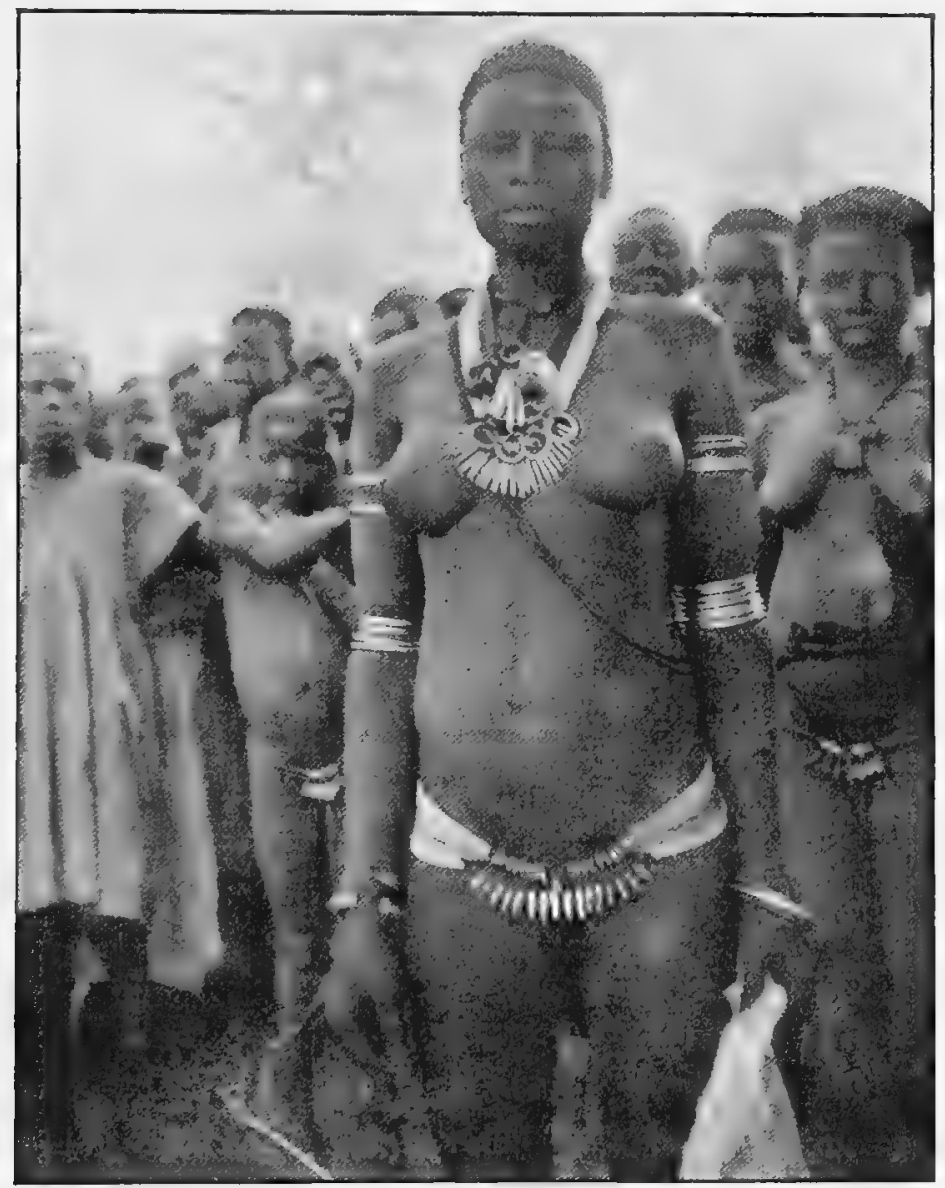

A KILBA GIRL NFAR YOLA

with brass knobs. Round the chests and flanks the horses wore padded surcoats, so thick that no arrow could pierce them. With them marched a company of fifty spearmen and a band, consisting of some drums and reed instruments, which in the distance I took to be bagpipes. The spears 
were very fine, many with blades almost as broad as Sudanese ones. The hafts were light, long and straight and were made from the roots of trees. In addition, both cavaliers and spearmen carried one or two barbed throwing spears.

The Kachella proposed, if I had no objection, to reinduct the ex-king of Ndivva who had been driven out by a usurper, as mentioned above. He asked me to accompany him to the town next morning for the purpose. This I did and presided over the ceremony. The Kanuri sat in a halfcircle facing the ex-king and his followers. Both sides made long speeches-the Marragi in particular seemed to punctuate their remarks by continually drawing lines in the dust with their fingers. The chiefs first smoothed a piece of ground before them, and then at each point that was made by their own party or their opponents, drew a line with the index finger in the dust. Towards the end of the negotiations the ground looked like a tally-board. I believe that each drew one long line and then marked his own points above, and those of his adversaries below this, but I cannot remember whether dots were interspersed to separate the speeches. So far as I could gather the custom has not reached that stage of development in North Nigeria, which it has done among the Bavili of the Congo. As far as I could follow the negotiations, the chief difficulty seemed to be as to how many goats and sheep were to be paid to the Kanuri as the price of their aid.

When things were settled I went on to the first hill of all, to replace the subtense flags. Groups of Marragi were collecting, and affairs looked far from promising. After leaving two soldiers in charge of the flags with orders to rejoin me at 
nightfall, I returned to Ndivva to inquire about the three sheep which had been stolen. The chief said that they had been taken by some very bad men who lived in a village a little way off and robbed and raided the whole country round. He offered, however, to go with the one remaining soldier and try to get back the sheep. When this had been agreed to, I went on to the hill above Abila and at nightfall descended to the village itself. Just after my arrival, the soldier who had gone in quest of the sheep came running in. He had had to flee for his life, which according to his own account he had only just managed to save. The people of the village had shot a great many arrows at him and had caught and beaten the new king. Messages also came from the same quarter that they would treat me and my party as they had done three soldiers whom they had captured and killed a little time before.

The two soldiers left to guard the subtense also arrived in an excited frame of mind, saying that all the Marragi were gathering together to attack us. It was obvious that something must be done if the work was to be carried through, and also, had I passed over all these insults and threats and attempted to leave the country on account of them, the Marragi would have thought that we were afraid, followed us up and probably annihilated the whole party amid the long grass or millet, where we should have been helpless. It seemed to me that the only chance was to appear before the village of the ringleaders next day in hopes that they might be taken by surprise and give in. Directly after dawn therefore, I went up the hill and finished my observations; then, after lunch called the carriers together and told them 
that I was going to pay a visit to the village and fetch back my sheep. The headman at once stepped forward and said that as there might be trouble they wished to come too. I armed them therefore with the spears, swords and clubs which I had been collecting as curios; my gun-boy was made happy with my rifle, and a horse-boy with my shot-gun. Then, together with the three soldiers, about twenty-five in all, we started out by a circuitous way to the village. I had purposely waited till now in hopes that the Marragi would by this time have given me up for the day, withdrawn any ambush placed for me, and retired to their village. For this reason I had only mentioned my intentions just before starting, so that no rumour of them could possibly have got abroad. Before setting out the men were informed that I hoped if possible to recover the sheep without bloodshed, and very strict orders were given that not a blow was to be struck unless we were first attacked.

After about an hour's march we appeared suddenly before the village. The Marragi, though taken by surprise for the moment, had evidently prepared for us earlier in the day. All their women and children had been sent away and they had gathered allies from neighbouring villages. There were at least 150 of them, but our sudden appearance and their ignorance of our numbers, which they could not estimate owing to the millet which stretched right up to the houses, made nearly half of them take to the bush at once. The rest received us with a volley of poisoned arrows, which were too hastily aimed to do any damage, and, after a scuffle, they were driven out of the village by our party.

Some of the bravest of the enemy now formed up behind 
a group of trees, which commanded the narrow exit at the rear of the village, and began shooting into our party.* A few of the carriers fell back for a moment, but soon rallied and a rush was made, in which they swept everything before them right up to the top of the hill, where the grass was short, singing a very fine war-song as they charged.

As an example of the state of civilisation in which even the Hausas still are, it may be mentioned that my gun-boy, who belonged to this race, came up and politely asked if I would like the head of a Marragi killed by one of the soldiers ! The carriers, whose blood was up, now wanted to pursue the enemy, and were only with difficulty prevented from doing so. At this juncture some of the Kanuri appeared and offered to act as peacemakers, and that evening brought in our sheep with some others as a peace-offering. They also told me how pleased they were that the Marragi had had this little reverse, as there would now probably be a short respite from the murders and robberies which had been continually taking place. The district had not then been brought under British control.

The men had behaved so well that they richly deserved a feast, so some of the recovered sheep were devoted to this purpose. They had been doing hard marches for months past, over swamps and up mountains, sometimes with very little food, and almost without a murmur. They had now shown that they were not only good carriers, but good fighters as well. Their charge up the hill was quite an inspiriting sight. They were affectionate fellows too, for,

* It was during this fight that one of the Hausas was severely wounded by a poisoned arrow. Without the slightest hesitation, Talbot sucked the wound and so saved the life of his follower. 
in the course of the evening, they were singing with such enthusiasm that I asked what it was all about. They answered that they had composed a song to say that they loved the two white men (Alexander and myself) "bad"and would always do their utmost for us.

Later, we had reason to fear that these same Marragi captured and killed a messenger sent to me by Alexander from Gujba with letters. Only two curios belonging to this tribe have come into my possession. A bow and shield, the latter made of very thick ox-hide hammered all over into little bosses and more or less the shape of those used by the Roman legionaries. Most of the Marragi are of remarkable physique, and a large percentage of them are certainly over $6 \mathrm{ft}$. in height. They are very black, with thin lips and beards. They are good elephant hunters. It seems that parties of about twenty mounted men are made up, who attack the elephants with nothing but poisoned spears. When the animal turns at bay, each one in turn tries to take of the attention of the elephant from the man it happens to be pursuing. It is very rare for the party to come back with less than one or two men killed and wounded.

The day after the fight we moved on to a hill near Arris and found, as I had feared, that a dead level plain lay to the north and north-east, not only without hills, but absolutely devoid of conspicuous points.

On September 11 we marched into Bornu territory. As we left, one of the carriers received a last greeting from our friends the Marragi in the shape of two arrows, which only penetrated the long garments which he was wearing. This was fortunate for him, as the poison used on these arrows is 


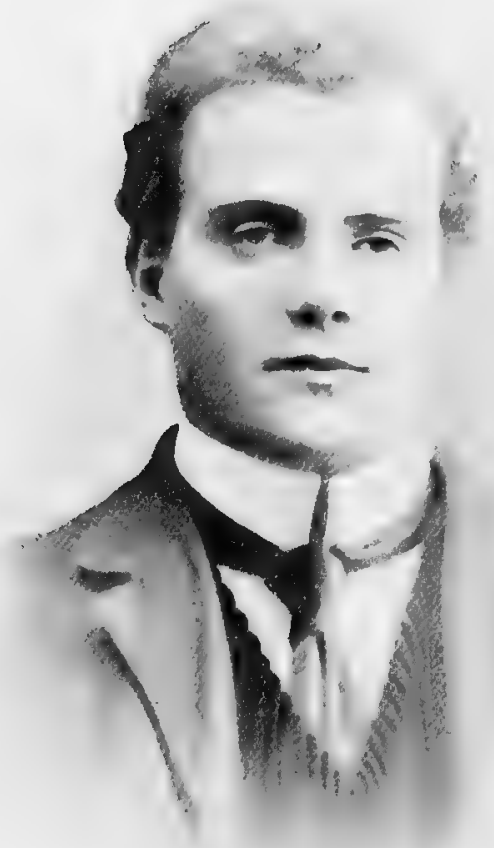

MP. P. A. TALBOT, B.A. 

so virulent that people often die in twenty minutes after having been hit.

The next night was spent at Munyi, quite a large Bornu town, and from a spot to the north-east of this an azimuth was taken to the hill near Arris. We had now entered the Plain of Bornu which stretches right up to the shores of Lake Chad, and the only way of surveying across it was by a tedious rigorous traverse. The carriers cut a line through the bush as straight as possible. This I measured and took theodolite angles. Working from dawn to dusk by this method we generally managed about half a mile to a mile a day, according to the thickness of the bush to be cut down. Our chief difficulty was want of water, which usually had to be brought from the nearest village. We here found the Kanuri bottles very useful. These are made of grass, so closely woven that they are quite water-tight, and are really a beautiful piece of work.

At Balamingubdo a small baby-boar was presented to me, but this made itself such a nuisance, that I gave it away again, and its fate among hungry carriers can be better imagined than described.

At Dallguri my interpreter came up and asked for some money with which he bought one of the pretty green paroquet which abounded in the neighbourhood. He then killed it and took a small part to wear as a juju. He said that it was a most powerful magic and that so long as he wore it no one would be able to kill him.

There was a great amount of millet grown near the towns round here. The harvest had been abundant, so we had no difficulty about food. The bush abounded in ground 
squirrels, and monitors of which I got several. Many of the names of the Bornu towns, especially in this neighbourhood, end in "ri." This suffix denotes "belonging to." "Digimari," for instance, means (the village) belonging to Digima, and "Shuari" one belonging to the Shua. They are mostly named from their owner or headman, but are sometimes called after some peculiarity or other. For instance, "Balamingubdo" means "the town of a hundred years," and is so named because it has existed for a very long time in the same place. This is a somewhat extraordinary occurrence, as the people of a village usually exhaust the soil round it in a comparatively short space of time and move on to another spot. Near Digimari was a small stream which was said to be the source of the River Shari-Wase at Maifoni.

On September 19 Alexander at last rejoined me, bringing with him a lot of provisions which were most welcome after the forced living on the country. Those which he had sent according to promise never reached me. From Gujba he had been to see the Resident of Bornu at Magumeri, where he had had an attack of fever which lasted for several days. From that place he had gone to Maifoni and then come south in search of me. He also brought a mail which had not reached me for a long time past. As a matter of fact, only about half the letters sent out ever reached me.

The news of our little fight had apparently travelled right through Bornu almost as soon as it took place; which shows how quickly native reports can spread. Alexander also said that he had met Gosling at Gujba, and that the latter had gone on with the boats to the Yo river whence he would take them down to Chad. 
After Alexander's arrival work went on much more quickly and we got through on an average two to two and a half miles a day. He brought a great many extra carriers with him and hired others from adjacent villages, so that altogether there were about a hundred men at work. He always went on ahead with the men and had a lane cut through everything, while I came behind, measuring and taking angles. For the next twenty miles one had to spend more than half the day up to one's knees or waist in water, as swamps lined our route on both sides.

(End of Mr. P. A. Talbot's narrative.) 


\section{CHAPTER VII}

UP THE GONGOLA RIVER TO ASHAKA

I MUST now go back and trace the journey of the boats from Ibi by the Benue and Gongola rivers to the new base at Ashaka, where it was arranged that the expedition should concentrate before continuing the forward movement into Bornu. I had arranged that José should take the boats as far as the mouth of the Gongola, and there wait for Gosling, who had in the meantime accompanied the survey party as far as Wasé, from which place he struck north-east on a hunting expedition to look after giraffe, which was said to be found in the district. Having had evidences of their presence in the shape of a jawbone and tail of an animal, which had been killed in the neighbourhood a few weeks previously, Gosling set out from a village called Sarua, attended by an old native hunter named "Sarriki bakka," or "King of the bow," and a retinue of seven others, a most picturesque lot, clothed in the skins of animals they had killed, and laden with hunting kit of bows and arrows, leather bags full of food and odds and ends, tobacco pouches and a musical instrument and various ju-jus. After riding two miles, the bush became very heavy going for his pony, as the ground was soft with a deep deposit of sand brought from the Sahara by the harmattan wind, so Gosling sent him back; and also the water of the district he was now entering was 
said to be fatal to horses, nor was the country free from the tsetse-fly.

Five hours' marching east of Sarua, the path crossed

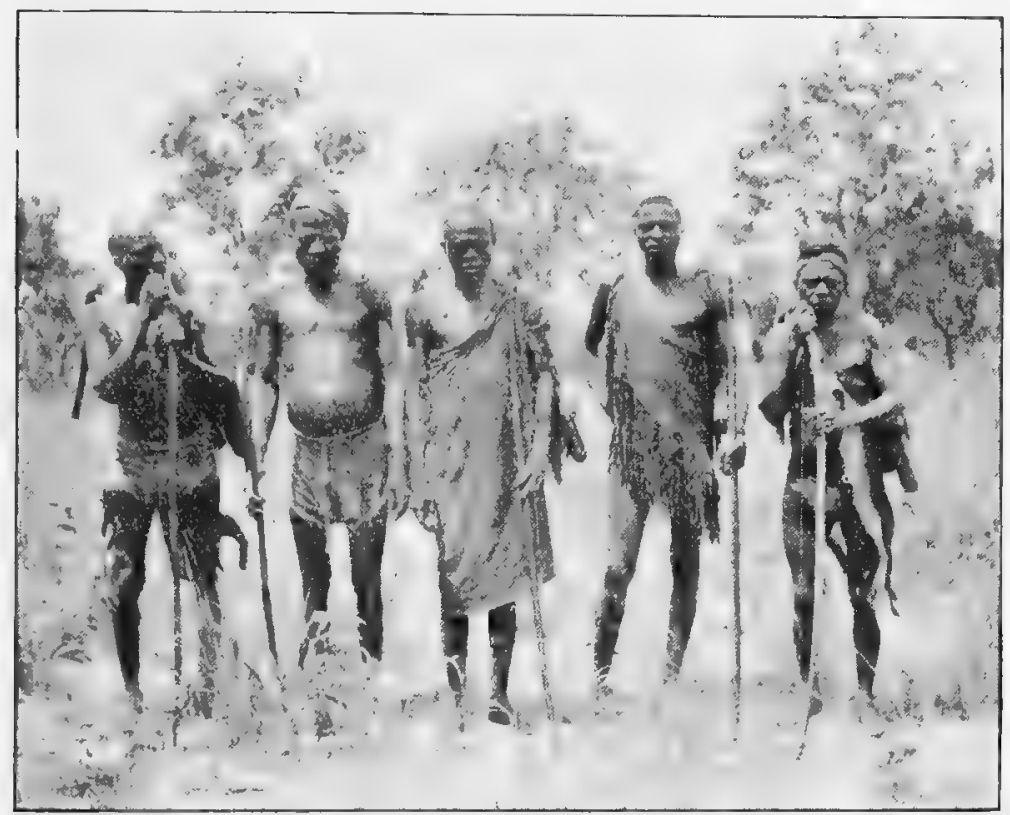

THE GIRAFFE HUNT. (SOME OF THE " FIELD")

fresh tracks of a giraffe, which Gosling and his band followed up. Soon some of his Sarua men spotted the beast by climbing to the top of a high tree. They all pursued at once until they again caught sight of him-or rather a few spots of him, for the bush was very thick. The anjmal was, however, on the alert and Gosling had to take a quick shot at 170 yards. The shot took effect, but not fatally, and two or three more in a running pursuit were necessary to bring him down. On examination it was found that his aim had been too low. Then followed three hours of hard work 
getting the skin off, racing a tornado that passed threateningly near. Camp was pitched upon the spot, and the Sarua hunters were busy far into the night drying over fires the strips of meat that strewed the whole place round. This work was continued most of the next day, and the camp was enveloped in an atmosphere of meat and smoke.

Gosling does not speak very enthusiastically about the edible qualities of giraffe meat; he describes the kidneys at breakfast as a failure, and stewed tail, steak, or tongue as no food for the white man. Soup made of the tail was the only thing possible and that had to be disguised. There was a superstition among the natives that the slayer of a giraffe would be inflicted with madness, and peculiar forms of ju-ju had to be observed to avert this fate. Gosling was made to take a certain kind of snuff, and the natives rubbed it on the tops of their heads. The tuft on the head of the giraffe and its whiskers had then to be singed, and Gosling was only just in time to rescue the tail from being cut off.

The roan antelope is the only other ju-ju animal among these people; it is held in even greater awe than the giraffe, and the old hunter said that they rarely dared to kill it. He also said that both black and white giraffe had been got in the country.

On the way back to Sarua, two more giraffe were seen, a mother and her young one, which made off suddenly as the wind was blowing strongly in their direction. Gosling's giraffe is the first that has been obtained in Northern Nigeria, and the head is now to be seen at the Natural History Museum, South Kensington. Some of its measurements were $11 \mathrm{ft}$. 
from the shoulder, $16 \mathrm{ft} .4 \mathrm{in}$. from fore-foot to tip of nose stretched out, and length of tail $2 \mathrm{ft}$. $7 \frac{1}{2} \mathrm{in}$.

On this journey he passed through a town called Bashar, which he described as a perfectly delightful place, situated on a hill with a magnificent view to the north and west. It is

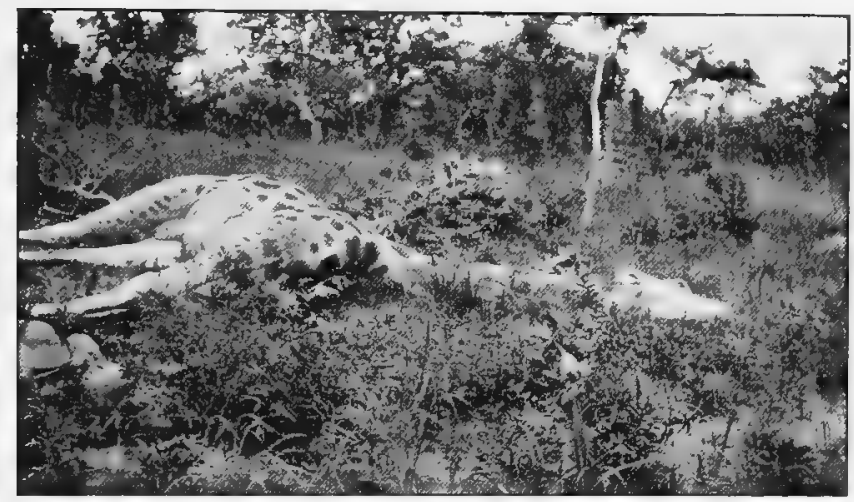

GOSLTNG'S GTRAFFE

surrounded by a wall, and ripening millet was growing right up to the city gate, and beyond there were broad fields of guinea-corn, where the women, among whom were the king's two wives, made a pretty sight, perched up in the trees, scaring away the birds. Within there were little patches of crops, water-pools and trees, scattered huts and compounds, and the king's palace with a wall and imposing gateway, near to which Gosling camped. The king, who was charming, sent a present of chickens, onions, and fresh milk from his only cow and a large amount of meal for the "boys." Outside the palace gateway were two huge stones, each weighing a ton, and facing east and west, on which the king was wont to sit morning and afternoon basking in the sun.

From Bashar Gosling went by Shumar to Gudu, where a 
great reception awaited him, for the King of Bashar had sent news of his coming. Thence back to Sarua, where he pitched his tent under a fine kuka-tree on the top of a hill opposite the king's house. Here again a beautiful prospect faced him to the south and east. He describes this as a very enjoyable time, in a pleasant land with happy, hospitable inhabitants, fine weather and plenty of game; duiker, hartebeeste, bushbuck, pig, roan antelope, giraffe and elephant to delight the heart of the hunter.

The people of Sarua make a very fine cloth, besides tobacco pipes and pretty water-pots. A little incident which happened here is worth telling to show the gentle nature of the inhabitants. Three of the carriers were caught looting in the village and it was necessary to administer "bulala" (or the rod). The villagers looked on with childlike merriment, and when it was all over, the brother of the man whose property had been stolen came forward and presented the culprits with a handsome "dash" of food.

From Sarua, Gosling took the road back to Ibi, where he arrived in eight days. After packing up his skins for England, he went by boat up the Benue as far as Lau, which is about 130 miles from Ibi. The river presented a magnificent sight, having received its full complement of water from the rains. No sandbanks were to be seen in its broad stream, which had an average width of a mile. The country here is peopled by the Bashimas, but the population of Lau is a very mixed one, including Hausa, Fulani, and Nupe traders. The Niger Company encourage them to work the country by giving them free passages up the river in their boats. The products of the country are gum, rubber, nut oil, 


\section{UP THE GONGOLA RIVER TO ASHAKA}

tin, and arrow poison, called by the natives "oguni," which is also useful in medicine. The trade goods that buy these are black cloth, salt, beads, enamelled buckets and basins.

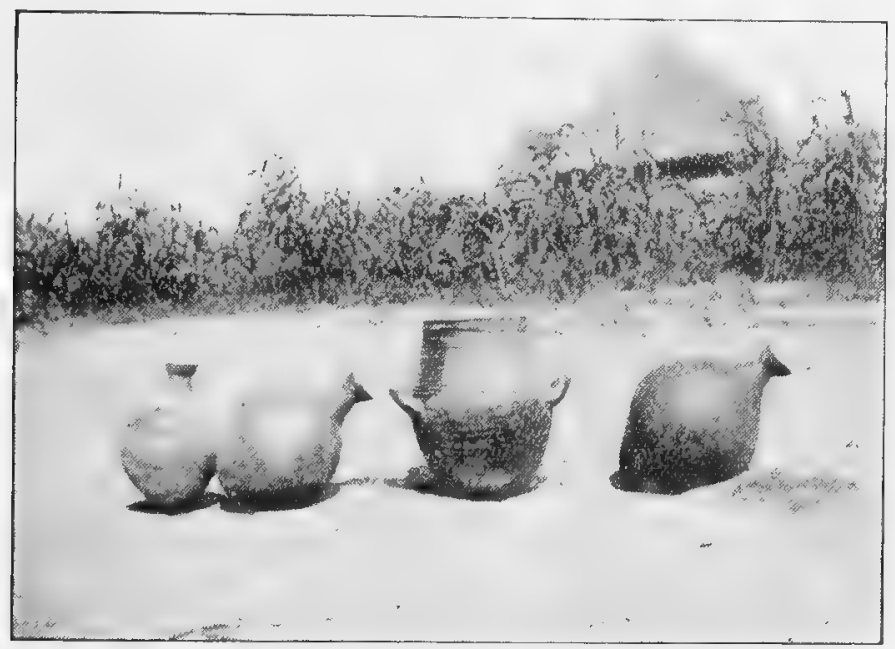

POTTERY AT SARUA

Lau formerly did a big traffic in slaves, and a certain amount still goes on secretly. There was a great scarcity of food in the place at this time, partly owing to a punitive expedition a year ago, and partly to the failure of the crop of guineacorn, which had been visited with a certain destructive worm. Besides, the Bashimas are an improvident race, and careless in their farming.

The natives along the banks are of fine build. They have a fashion of scarring their arms all over with deep gashes. Lau is under the Sultan of the Muri province. The last ruler made away with the clerk in the Niger Company's store, and, appropriating the key, sent in whenever he wanted 
supplies. He was never punished and was still in possession when he died.

One day an old ju-ju man came through the town, selling medicine "to prevent scorpions from biting people." He had five black scorpions with him, which he handled freely and lodged in his beard. They did not seem to be very lively, and as the old man said he fed them only once in ten days, the diet must have consisted of his ju-ju, it had rendered them so harmless!

After waiting a week at Lau in hopes of getting a lift in a Government boat, which, however, failed to make her appearance, Gosling succeeded in getting hold of a Bashima canoe. Accordingly, he at once made a start up the river, for he was getting anxious about José, who was waiting for him at the mouth of the Gongola, and probably having great difficulty to feed his polers and boys in such a faminestricken country as the Gongola region was reported to be. He had his bed put up the first night on the left bank close to a little Bashima fishing-station, where the people, who were very nice to him, seemed to be pure savages, naked except for small strips of cloth. He was struck with the number of bead ornaments that many of the men were wearing. At night they fish with large circular nets, fixed in wooden hoops about $12 \mathrm{ft}$. in diameter. They use no bait, but simply let down the net where the fish are likely to come to feed; then wait in their little grass shelters on the bank, before returning to raise it in hopes of catching a chance fish or two.

Next morning he made an eariy start and was well on his journey up the river, when he was pursued by the Bashimas, 


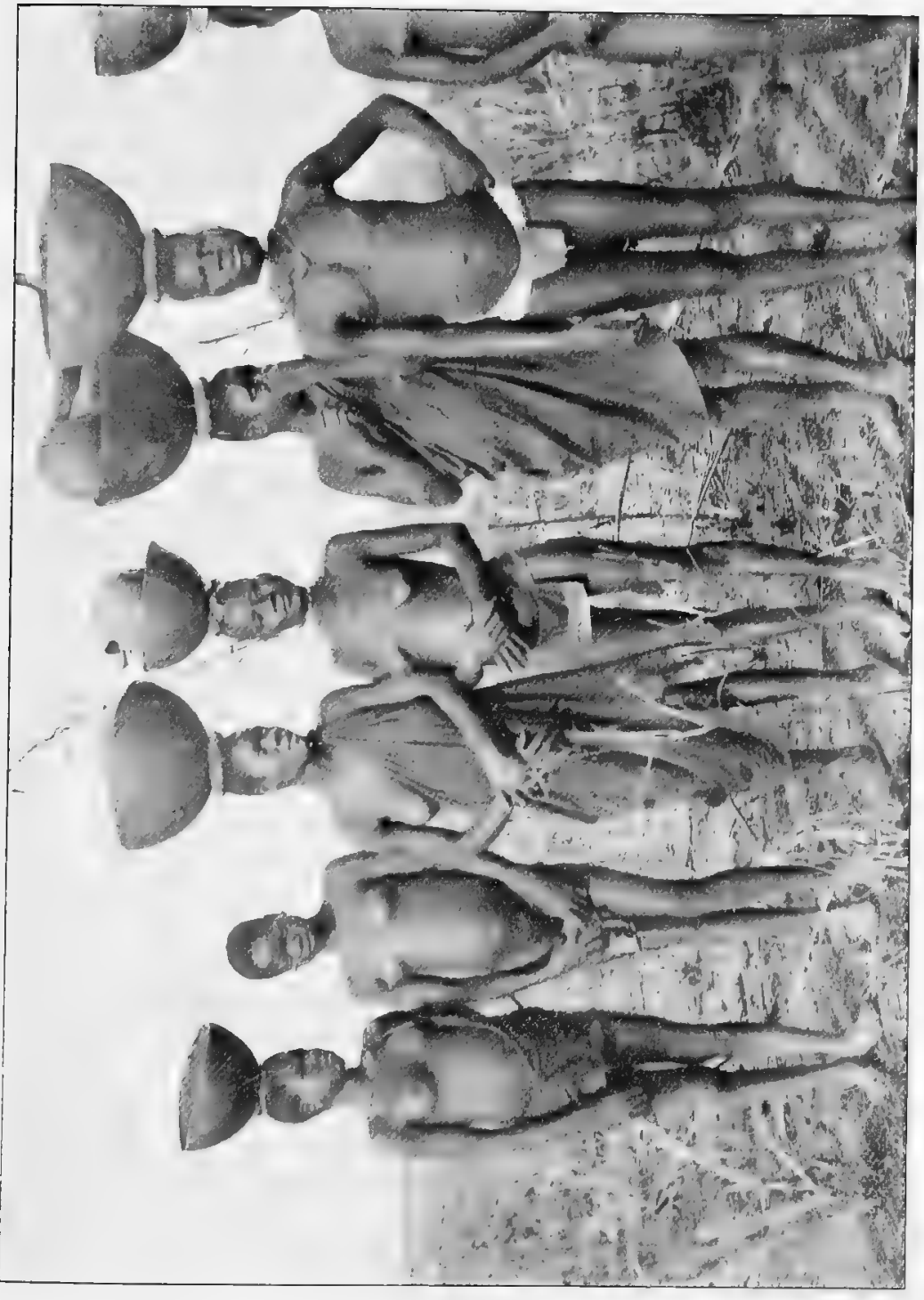

告 

bringing along the rods of his mosquito curtains, which his "boy" had forgotten and left upon the bank. A typical case of pagan honesty.

Good progress was made that day poling along the shallows out of the main stream, close under the overhanging bank which the water had hollowed out. Sometimes a fallen tree blocked the passage and the canoe had to be taken round against the current. Once it got into difficulties, and some baggage was thrown into the river. This was afterwards recovered by two Bashima canoemen, but meanwhile darkness had come with the delay, and it was necessary to stop and camp in the long wet grass by the river-side.

Next morning the stern-wheeler Empire overtook him, so he boarded her and his canoe was taken in tow. She arrived the same day at Numan, at the mouth of the Gongola. Here there were distinct signs of famine, and the old men and women and the children looked very emaciated, but the strong men's appearance showed that they had been able to look after themselves.

In the days of slavery this place was flourishing, as there were plenty of men made to work and so there was an abundance of food. But now the people are a lazy and improvident lot, and the failure of one season's crops brings famine.

Gosling was much disappointed to find on his arrival that José had been unable to wait for him owing to the scarcity of food.

It will now be necessary to leave Gosling at Numan while we follow José's journey for a while.

We have seen José depart from Ibi with the boats and 
four native canoes, carrying 400 loads for the new base, Ashaka. At Lau, which he reached a week before Gosling's arrival, he had great trouble with his crews. Next morning, when he wished to continue the journey, the men fell in and came to him to say that they could not start that day as they had heard there was famine in the Gongola country, so would have to wait and collect sufficient food to take with them. So José granted their request as they asked him, and gave orders that a start should be made at six o'clock next morning. When morning came, he struck his camp and went down to the boats, to find that all the crews had disappeared. So he sent his Hausa escort into the village to look for them, but without success. José then went to the king and told him that if his men did not make their appearance by twelve o'clock, he would put him under arrest, and send him in to the Resident at Ibi. The king sent a man with a drum, sounding round the village and shouting woe to any one found concealing José's men. This had the desired effect, for half an hour before noon the men came into camp. When asked their reason for running away, they replied that they had heard that the Gongola river was dangerous, the people cannibals and famine in the land, and they said that they would all die if they were to go there. After much persuasion, with great difficulty he managed to induce them to start on the journey, and five days afterwards he arrived at Numan. On his approach he saw a very large crowd, which, on inquiry, he was told was a market going on. When the people caught sight of the boats, they all ran away, for they were buying and selling slaves and did not care for a white man to see them. Here he had much difficulty in 
getting food, only managing to buy four gallons of Indian corn from some Fulani traders, which cost four yards of calico.

On the next day he commenced the journey up the Gongola. There was such a strong current in the river that it was impossible to get along by means of poles, so he had to get natives to tow the flotilla from the banks. At a small village, three days up the river, the inhabitants brought him girls and boys to sell for food. He told them that he not only had none, but wanted to buy some himself. At another place he found a lot of slaves, fastened to stocks. José released them, which very much upset the king, who feigned ignorance of the illegality of his possessions. All the way up the river José had enormous difficulties to feed his men, for there was famine in all the villages.

One night there came on a violent storm, and one of the canoes was sunk with forty loads in $6 \mathrm{ft}$. of water. By diving, he and some of his men succeeded in recovering all except one box, which contained 1000 cartridges. Another time, while the crews were towing the boats up some rapids, the rope attached to the one he was in broke, and the boat was swiftly carried towards the rough water among the rocks below. José immediately jumped overboard, caught the rope and swam with it to the bank, where he managed to fling it round a tree just in time to save the boat from the rocks.

The journey up the Gongola occupied about eighteen days to Ashaka, where the Expedition was to concentrate again, and three days after José's arrival my brother and Talbot came in from the survey in the Kerri-Kerri country. My 
brother then went on with the stores to Gujba, where he collected carriers to send back to help with the boat sections. Meanwhile Talbot had started south to carry the survey into the Barburr country, with the intention of joining my brother again in the neighbourhood of Maidugari, in which

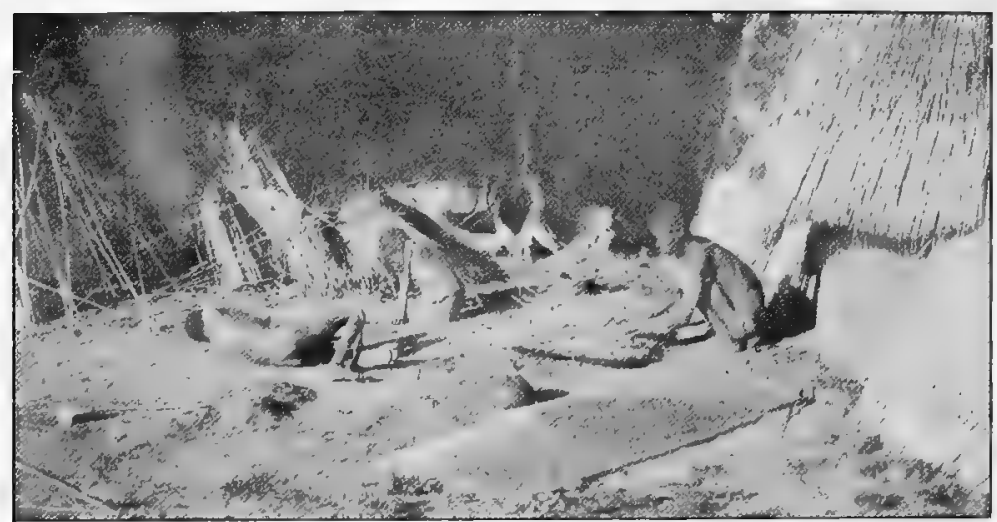

STARVATION AT BILTACHT

direction the latter set out, when José came up with him at Gujba.

We must now go back to Numan at the mouth of the Gongola, where we left Gosling who had arrived there a week later than José. On August 11 he set out in his canoe up the river seven miles to a Bashima village called Billachi. All the way no sign of life was seen except a stray goose or two. The village, too, had a deserted appearance, with broken walls and skeletons of inhabitants, who were subsisting on grass seeds and green millet. Many were said to have died lately, and he did not see more than thirty people in all. He sent for the "lammido," as the king of a village is called in these parts, and after a delay a bony old man came to him 


\section{UP THE GONGOLA RIVER TO ASHAKA}

with lamentations and woe to say that the lammido was just dead. In exchange for some wood Gosling gave him some biscuit, half a pound of meal, and a looking-glass which I should think must have given the old man a shock when he beheld his cavernous face within!

Gosling was in hopes there might be some game in the neighbourhood which he might shoot for the unhappy people, but unfortunately there was none to be seen.

Next morning all the polers struck, refusing to go on, for, after the dismal sights of Billachi, they feared that farther up the river it would be famine for themselves and food for the inhabitants, who were cannibals. However, they were coaxed on for another two miles, and then they struck again. After a quarter of an hour had been wasted in talk, Gosling managed to get them along again, and then they worked well, getting the canoe to move against the very strong current with marvellous effect. So they were rewarded with double "chop" that evening.

On August 3 he came to a point where a chain of hills crossed the river; on the farther side lay the village of Kiri. After this, navigation was easier, for the current was less strong. Away to the west there were bare, smooth hills, where a large village of the Yam-Yam people could be seen perched on a flat ledge of rock. The country all along the river on either side was covered with thin bush and long grass.

The next day he reached a place called Shillem, a village surrounded by an ancient wall. On the path thither he heard groans through the bush and eventually came upon a man dying of starvation by the roadside. The lammido of the 
village, a very decrepit old man, received him well, bidding him sit down on two leopard skins in front of him. He had

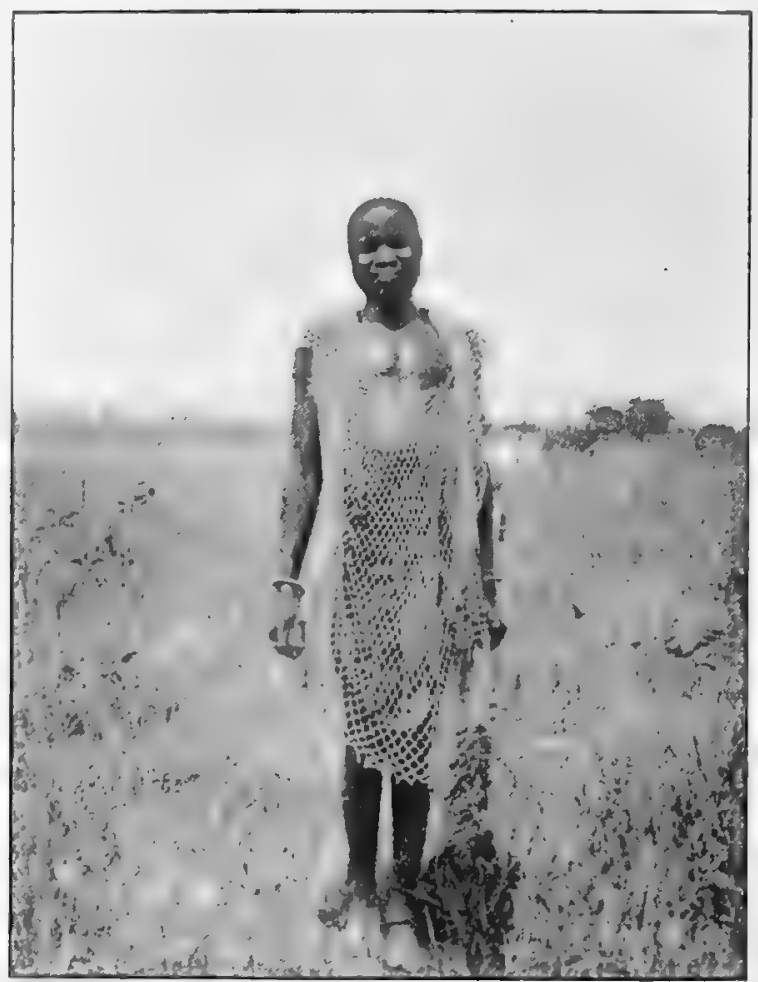

A MAN OF THE KARU-KORU

probably received news of Gosling's coming when José visited him a short time before. In the afternoon the old king rode down bareback on a grey pony, bringing a present of a sheep and a large quantity of firewood. There were some Fulani in this village as well as the natives of the place, who belong to a tribe called Karu-Kuru. Some of the men were wearing shirts made of open rope-work, and a few of the women had scars in remarkable designs all down their left sides. The 


\section{UP THE GONGOLA RIVER TO ASHAKA}

place was terribly famine-stricken, and the poor and old were eating grass. Six victims were said to have died the day Gosling arrived. The old king had ponies, sheep, goats, and fowls in plenty, but he let his people die.

Morning and evening the Fulani sent Gosling a large present of new milk, which was brought to him by a pretty little girl with three blue beads threaded in her hair and swinging on her forehead, and brass anklets with bells upon her feet.

In the middle of the second night at Shillem, Gosling was wakened by mosquitoes to find that his three polers from Lau had decamped, taking with them the paddles and poles. After a delay of three days the lammido managed to procure him nine carriers with a promise of six more from the Yam-Yam village of Frekhaio, two miles up stream on the other side. After a perilous crossing, in which they nearly went to the bottom, for the natives were not used to managing so large a canoe and their poles were rotten, the right bank was gained at a point a mile below the village. Here he made up the number of his carriers, and started for Kombo after a slight delay-caused by the news coming in of the murder of a Hausa and two Shillem men on the road ahead. It was a case of horse-stealing from the natives by traders, so their deaths were deserved. Gosling's Fulani guide talked the men round again all right, and they were soon upon the road once more. This led through pretty bush country and really good grazing-ground running right back to the Yam-Yam hills, which are down-like in appearance. Villages were passed where the people ran away on his approach. In these places the corn was nearly ripe, and sheep and 
goats abounded. The path then ascended through bush over high, rocky ground, to drop down and cross a fair-sized river to Kombo in the valley. From Shillem this had been a distance of twelve miles and had taken a day to accomplish, while the boats were three days going round by the river. The king was kind, and came out to meet him with a present of a sheep and goat and wood, and brought him to a pleasant camping-ground, promising to provide carriers for the journey on the morrow. About twenty-one were duly forthcoming, and among them Gosling discovered a young girl, good featured and with pretty markings down her side. She was wearing nothing but a thin strip of leather with a tassel on the hip, and was carrying a very heavy load which Gosling changed for a light one.

The path again led up over rocks, hugging the foot of a remarkable hill that ought to have been inhabited at the top by the robber chief of the story-book. It is flattopped, with tremendous precipices on all sides, and its melodramatic appearance was enhanced at this particular time by a violent thunderstorm that circled round its crest.

After fording the Yo river, sixty yards wide, Gosling arrived at Gasi, where, despite some difficulty, with the help of the decrepit old king, he raised a fresh lot of carriers. There were twenty in all, including a woman and two very old men. However, they were excellent goers and cheerful under their loads. Soon he crossed the river Devana, and two or three hours' march through bush and rocky hills brought him finally up through a beautiful rocky gorge, with a pretty stream below clothed in fine trees, making up a landscape that was reminiscent of Scotland. On the farther 
side he dropped down into the valley, where Wuyo is situated. Here he found an absolutely different country, peopled by the civilised Tera pagans instead of the various Yam-Yam tribes. Here was plenty of food and ripe corn, and a big thriving town inside a mud wall. The king gave him a great welcome and all the people crowded round him. A present of a sheep, two goats, and six calabashes of "chop" for the carriers was the royal gift to him. Gosling's first care was to have all his things out of his boxes to dry, for there had been a tremendous storm in the early hours of the morning before he had started, and in spite of a deep trench which he had dug all round it, his tent was 6 in. deep in water and his boots were floating about like boats.

In the town there were about 400 inhabitants of the Tera tribe with a small sprinkling of Kanuri and Hausas. They do a good deal of farming and grow indigo and cotton besides the usual corn-crops, mealies and gourds. They appeared to be living a life of peace and plenty from the fruits of the earth, doing no trading nor hunting in the bush, and weaving their cotton into cloth for themselves. The town is situated on low, rocky bush-covered hills. It is surrounded by a $10 \mathrm{ft}$. wall, thin and dilapidated and loop-holed for arrowfiring. There are four gates. The country to the northwest presents a grand view towards a long mountain of clean-cut rock. Gosling was the third white man ever seen to pass the place, and about the first to stop and camp. Consequently there was great excitement and curiosity among the people, who had to be kept back by some of the king's servants. The king's wives spent the whole of the day staring at him over the palace wall! Many of the Tera 
women are tremendously big in build. They have a method of covering the heads of their babies with a calabash as they carry them slung in their waistcloth behind. So, the children can sleep in comfort, protected from light and sun. The calabash is kept in position by a leather strap, fastened tightly round the mother above the breasts. The women wear a large number of leather and brass bracelets above and below the elbow, and small tin earrings and hair-pins of brass of local make.

Gosling left Wuyo with pleasant recollections of profuse hospitality and charming people. Before starting, the natives treated his "boys" to "chop." He could not take forward with him his excellent Tera boy-guide, Madi, as his next destination was Wadi, whose king had killed the boy's father recently in a fight for supremacy.

Wadi lies north-west. His way first passed through large stretches of guinea-corn, which had been much damaged by the heavy rains. In one place there was a broad lane mown through the crops by the torrent that had swept down a hill. A large number of palm-trees grew round about. Half an hour from Wuyo he reached a ford on the river Baiyo, and two hours' more marching brought him to the eastern end of the fine rocky mountain which he had seen from the hills of Wuyo. A mile farther he came to Wadi, a town very like the last, but half its size, with the walls crowned at intervals with old watch-towers. The king who killed Madi's father was evidently very nervous lest Gosling might have brought Madi with him, for the boy had sworn to kill the king. The latter grovelled and threw dust on his head before Gosling, whom he presented with a sheep 


\section{UP THE GONGOLA RIVER TO ASHAKA 161}

and goat and plenty of "chop" for the "boys," with promises of men for the morrow's march. While here, a man from the

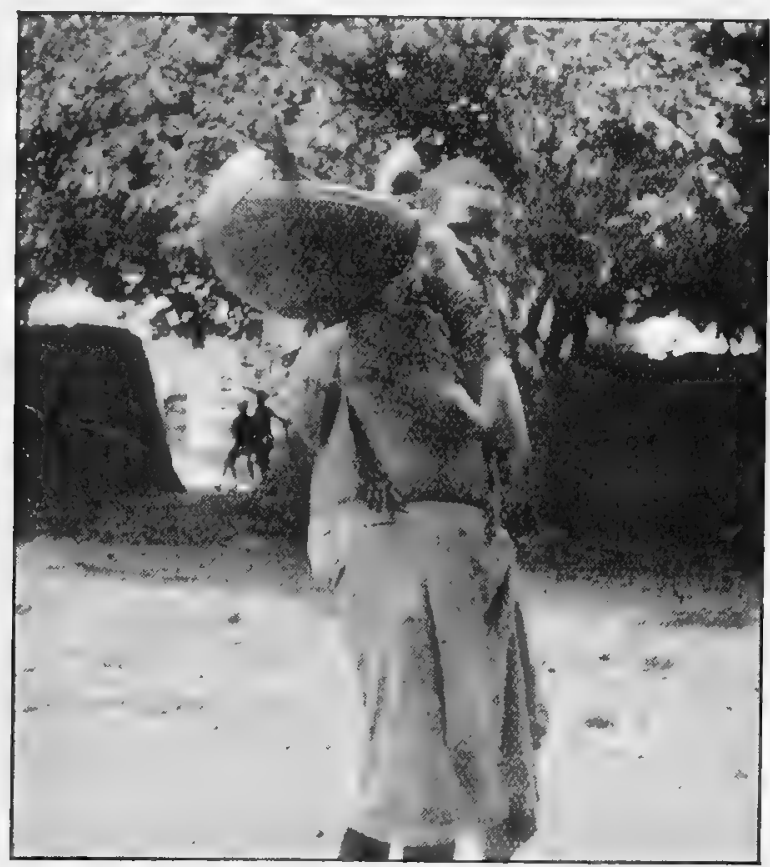

MOTHER AND CHILD AT SHILI.EM

(SHOWNG METHOD OF PROTECTION FROM THE SUN BY A CALABASH)

village of Teri came to him to say that four men, who seemed to be masquerading through the country as soldiers, demanding food, stealing horses and killing their owners, had just been there and stolen his property. So Gosling sent out a strong party to try and capture them. Next morning three of the four were caught and brought in, but the ringleader had escaped. Who should they turn out to be but some of Gosling's old carriers, returning from taking down loads to Kukawa! Two had broken heads and had lost all their kit 
and books of payment, so Gosling considered they had been punished enough and only made an example of the third.

Continuing his road, he reached a small town called Kupto, walled in and double-dyked, with a plank bridge over to the gate. This had been a march of seventeen miles through a difficult bush country and with a deep river to cross. On the way he had seen much spoor of giraffe and roan antelope. He stopped at Kupto and got carriers for the next day's march. He found these pagan carriers excellent; they were cheerful and willing, travelled very quickly, and, when warned, never touched the crops through which they passed.

A little way on, he crossed the river Banzi, wading up to the neck; then passed through two villages, both quite deserted. At the last, which was named Duell, he halted for water; as no living being could be found, he took a drink from a water-pot that was handy, and on leaving put some tobacco in the calabash that acted as a cover. Soon after he heard the grateful "O Wah!" from an old woman who had evidently been secreted in the crops. The country for a long way became dull bush and tall grass over $7 \mathrm{ft}$. high. Later he passed the ruins of Nassa, leaving the ruins of Burmi 600 yards on his left, and arrived in Ashaka mid-day on August 24, four days after my brother and Talbot had left there, so that the concentration of the expedition had been timed pretty accurately. José was still there collecting food in the neighbouring country. Meanwhile, four oxen and thirteen donkeys had come in from my brother, so the sections of one of the boats and forty-three loads were sent on to Gujba Gosling following on the 30th, not sorry to leave Ashaka and its cripples, flies, and dogs. 


\section{CHAPTER VIII}

THE JOURNEY OF THE BOATS TO YO

Gosling arrived at Gabai in the evening; a big-walled, Kanuri town with a very hospitable king, who gave him a goat, a sheep, two fowls, and eight good eggs. Here he found a note from my brother, who had passed through two days before on his way south to join Talbot. This town appeared to be very flourishing and abounded with flocks and herds, and various kinds of grain crops growing in a broad stretch of open land that had been cleared from the surrounding bush.

His next stopping-place was a large, prosperous town, called Mutwe, ruled by a cheerful and youthful king. All around the land was very swampy, and a tremendous music from crickets and frogs filled the air which was blackened by a threatening thunderstorm, that broke heavily the next morning and delayed his departure. The last part of the journey to Gujba, where he arrived the same day, September 1, led through very fine bush with numbers of big baobab (or kuka) trees. Thousands of butterflies feeding in bunches upon the road were a very remarkable sight. Butterflies in Africa, and bees also, are often to be found feeding on rotting carcases, from which they fly up in clouds on being disturbed. I suppose the scarcity of flowers in the dry season has cultivated the more robust taste in them. 
On September 3, my brother, looking very fit, turned up from chasing Talbot for six days. Having collected nineteen oxen and twenty-five carriers, he left again on the 8th for Maidugari. José came in the same day with the other boat and the rest of the loads. Meanwhile, Gosling had been busy repacking the boxes, many of which had got wet on the Gongola, and much of the cloth had been spoiled.

On September 9 he started for Gaidam with 133 loads and a transport of one hundred donkeys and ninety carriers: José following two days afterwards with the boat sections.

The next twenty-seven miles was waterless bush, but he was lucky to find at the end of ten miles a small waterhole filled by the recent heavy rains, so he pitched camp and continued the journey next day to Gabai Kalima, where the young king received him well. He had sent on a messenger beforehand to order supplies of food for his large number of men and beasts, and now found ninety large calabashes of meal, five fowls, and twenty-two eggs waiting for him. The eggs were all good, which was quite a record. Once a neighbouring king sent in 500 eggs to Gujba, of which only eleven were good!

September 13 found Gosling at Gunsha, a large Kanuri town; very tired after a thirsty march of twenty miles. On the way "Wuka" was kicked in the mouth by one of the donkeys. He bled very profusely, much to the detriment of the clothes of his master, who carried him the rest of the way, for the day was very hot. Another pet of his at this time was a porcupine, that felt this journey very much and arrived in a state of collapse, from which, however, a drink of milk soon revived him. 
The next day Gosling reached his destination at Gaidam on the Komadugu or Yo river; not a very cheerful-looking place, standing in flat sandy plains that are the skirts of the Sahara. Square mud houses, very Egyptian in appearance, dusty and scorched by the sand-laden breath of the harmattan, and looking whiter for the contrast of the dark green palms and their sharp shadows upon the walls. There are camels too, that tell of the desert as the masts of ships speak of the ocean. A day north, and the next is a waterless journey of ninety miles. The native does this in two nights and a day on his pony, which he has trained to go without water.

Here he had a bad time with fever, so was obliged to take things easy for a few days.

José came in with the rest of the transport on the 20th, and the next few days were spent in putting the boats together and lading them. One hundred and fifty-six loads were got into them, so it was possible to disband the bullock transport, and the rest of the loads were taken by the fifty permanent carriers. The object of the expedition now was to get the boats and stores down to Yo, a small town, six miles up the river from its mouth, where it falls into Lake Chad. And from there to select a site and establish a camp on the shores of the Lake, whence to carry out its exploration.

A start was made on the 24th, Gosling going overland with the carriers and meeting José with the boats each evening at a prearranged point on the river.

The Yo is a beautiful little river, that takes its very winding course to Lake Chad through the thirsty plains of Northern Bornu. What living green there is concentrates along the 
banks, and very refreshing and unexpected is the sight of this narrow stream, with its deep water and clean-cut banks clothed in bright green, winding so sinuously, that it

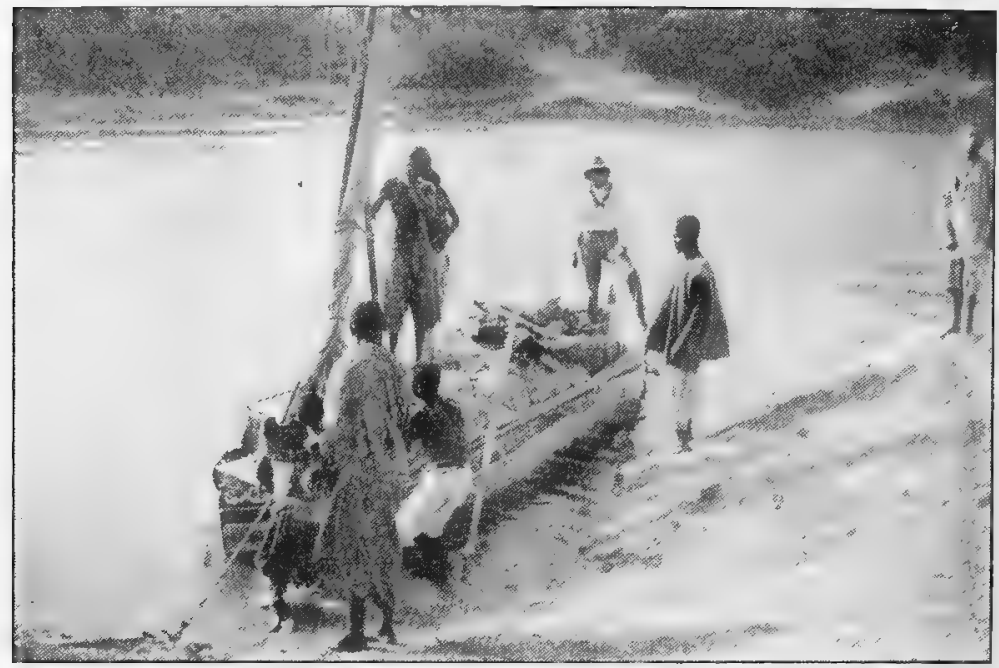

ONE OF THE STEEL BOATS ON THE RIVER YO

almost seems to be wandering aimlessly through the sandy plain like a river that has lost its way. After the broad currents of the Benue and its tributaries, the first sight of the Yo reminds one rather of an English trout stream, as it flows smoothly along with a current of little over a mile an hour through fresh green grass. Beyond both banks stretch undulating sandy plain the surface of which is broken only by burnt-up grass and occasional thickets of mimosa, with a few palm-trees. Now and again there appears a little patch of cultivation surrounding a native village. Isolated pools and backwaters along its course tell of the sudden rises in the rainy season, when the river overflows its banks. These are very beautiful with their fringe of 
green reeds and coverlet of lilies, and attract large numbers of duck and teal. There are no canoes upon the river and the natives cross on rough rafts of reeds bound upon cala-

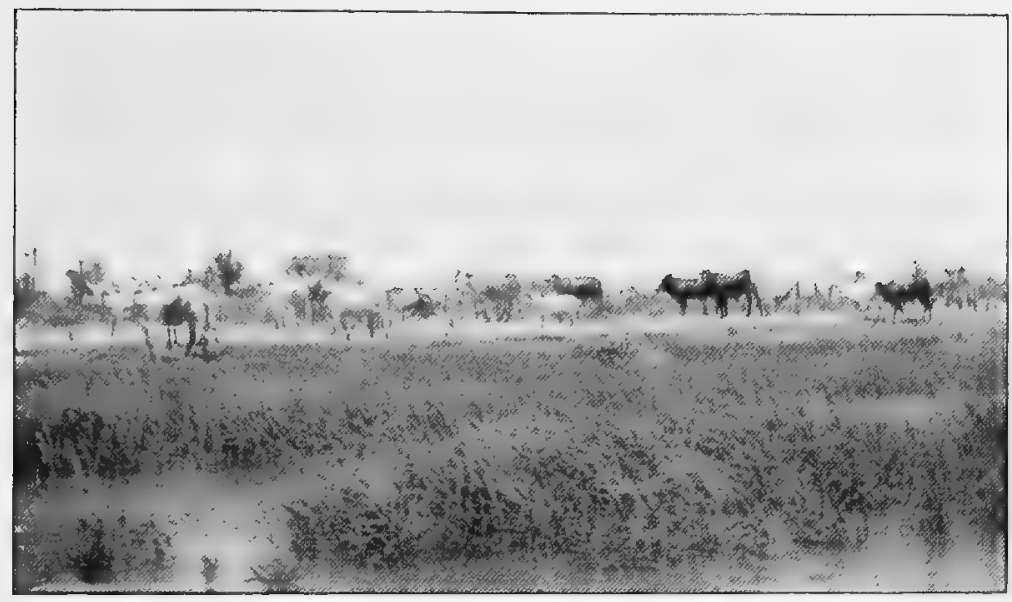

CATTLE ON THE RIVER BANK

bashes, or else swim supported by two large gourds fastened at either end of a bamboo, like a dumb-bell. Nor are the inhabitants of the river-banks very industrious fishermen. Occasionally one passes a little fishing-station where three or four men are working a huge circular net three times the size of those on the Benue, which I have described. But most of them reserve their energies in this direction till the falling of the river, when the fish are cut off by thousands in the pools. Then the natives come down in large parties to spear them, and little settlements of grass huts spring up along the banks, where the air for days is laden with the smell of smoke and fish, and the land littered with the heads and shining scales. For about four months, from April to August, the $\mathrm{Yo}_{\mathrm{O}}$ is nothing more than a dried-up watercourse, with 
an occasional pool of stagnant water which has been left " high and dry" by the sudden fall of the river (if one may be permitted the "bull"). Then the herbage on the banks

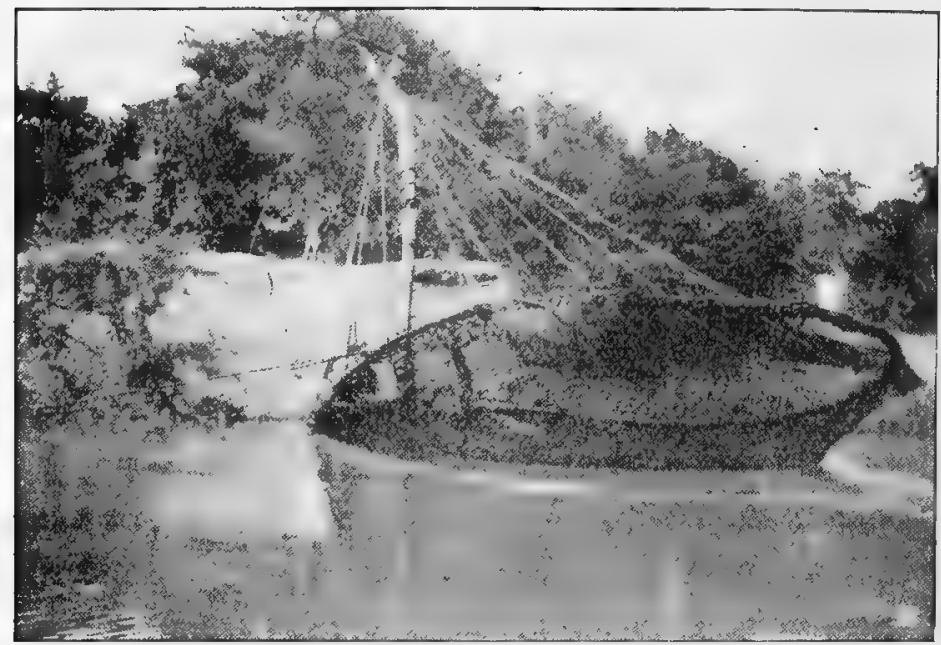

NATIVE FISHING-NET ON THE RIVER YO

is parched and the grass burns up in the fierce sun, and the herdsmen lead their hungry herds and flocks down to the shores of the lake where the short grass survives in the heavy dews.

The erstwhile fisherman is not idle while his nets grow brittle in the heat, for now all day long he toils laboriously, drawing up water with a calabash to fill the dykes in his little patch of corn. The women, who before dipped their water-pots in the river, take journeys to the distant well, and all men go armed with three spears in fear of the Tubu robbers who can now cross the river to raid. So they patiently work and wait, till one day the rumour is spread that the river is coming, and presently a breathless runner 
dashes wildly into Yo shouting the glad tidings and bearing aloft for witness a calabash of foam. Then all the town goes down to the river-bed, running forward to meet the

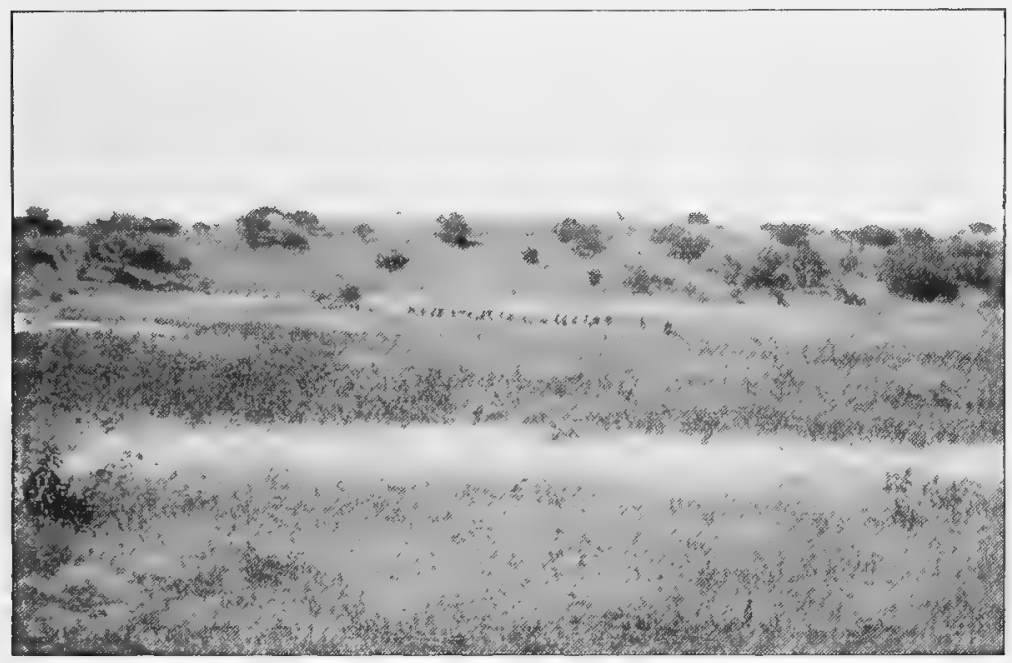

COOSIING'S COLUMN NEAR RIVER YO

oncoming stream, and raising a shout as the water slowly fills and overflows from pool to pool. And the mallams come down and kill a sheep upon the stones, mingling the blood with the waters of the river as a thank-offering.

The Yo forms the boundary between British and French territory, and since this was determined, there has been a great migration of the Mobbur communities over to the other side. For the French have no posts in this part of their territory, and the lawless nature of the Mobburs makes them prefer to live free of the obligations that an administration involves. Nor are they afraid of the Tubus who, rather than molest, treat them as allies and secret helpers in many of their raids upon the Kanuri, the hated tyrants who once 
oppressed the Mobburs, and whose rule is still paramount in Bornu by our protection. Further down the river the Mobbur villages are more numerous, and the boats caused much excitement among the inhabitants. Crowds of boys and girls ran along the banks, shouting and shaking their fists with imaginary spears. The Mobburs refuse to do anything for the white man, and often it was very difficult to raise enough food for the "boys." At one village José found the old king building a shelter for Gosling with his own hands as his people were all unfriendly, and at another the king came to Gosling saying that all his men were against him in the village, and not one would act as guide on the morrow, but that he would go himself. However, it ended in his headman volunteering.

Further down the river the people were more friendly and the King of Birrgumatulo gave them a very good reception. At this place an old man with a three-year-old gash in his chest from a crocodile came and asked for medicine, and Gosling gave him a bottle of iodoform.

It was on September 30 that he was at this place, and under that date in his diary he writes: "My porcupine is very precocious. He came and had a good drink out of my bath while I was in it, and then tried to get inside. He then began eating my soap and walked off with it."

Then under date, October 1, appears the note: "A sad disaster in the death of the young porcupine, the result of my long day in the boat yesterday and neglect of my boy to feed and water him during the day, as I was not there to see it done." Gosling was at this time journeying in the boats, as he had been feeling his old wound in his leg 
very much on the long marches in the heat over heavy ground.

He arrived at Bulturi in the evening; a Mobbur town, where the people were friendly and gave him food. At the smaller villages they ran away, but the larger towns turned out in force to view the sight of the white man and the iron boats, and at one place the civil old king lined the bank with his women, who clapped their hands and made a shrill yodeling noise, rattling their tongues against the roofs of their mouths.

One day a party of Tubu horsemen followed the boats along the left bank of the river, threatening to attack José. But when they discovered there were six soldiers on board, they cleared off.

I must not get too far down the river before mentioning the famous ruins of Ghambaru and Birni, which are spoken of by Barth in his "Travels." They are situated on the right bank, a few miles apart and thirty miles or so from Guidam. Those of Birni, which I visited on my own journey down to $\mathrm{Y}_{\mathrm{o}}$, consist of a broad grass-covered, circular wall and outer ditch about a mile in circumference, reminding one very forcibly of a Roman encampment. They are so buried over with turf that I could find no trace of bricks. But Gosling, speaking of the ruins of Ghambaru, says, "The bricks are in a wonderful state of preservation and one bit of the wall that is still standing is $15 \mathrm{ft}$. bigh. The thickness of the walls is $2 \mathrm{ft} .6 \mathrm{in}$., and the bricks are laid in alternate header and stretcher rows." Barth says that these towns were the favourite retreats of the ancient Kings of Bornu, and were destroyed by the invading Fulani in the year 1809 . 
He goes on to reflect upon the mournful comparison of this solid mode of building of former times with the ephemeral architecture of the Bornu of to-day as sad evidence of a retrograde race. But it seems to me very difficult to believe that the arts of brick-making, and of building houses solid enough to rank as architecture, could ever have belonged to the people of Bornu, and then have perished so utterly as to leave no trace of themselves in the direct descendants of those by whom these cities are said to have been founded. Is it not far more likely that the powerful king who built them in the fifteenth century was one of an alien dynasty, which, having conquered the land, held it by military power, and used in forced labour the unintelligent natives to make bricks for them and build blindly from their designs? To such an origin are due the splendid castles which crown the heights of the west coast of Africa-relics of the Dutch occupation, that has passed away without leaving a trace of the builders' art in the descendants of the slaves who raised those walls for their conquerors and cemented them with blood and tears.

On October I Gosling arrived at Bulturi, to find that the Kachella of Yo had passed through the same morning with a hundred horsemen on his way to Gaidam, scouring the country for Tubu raiders. He sent back a message to Gosling saying that he would send a headman to Yo to see after things for him. The next stopping-place was Pogwa, where a good many ostriches were to be seen. From this place he made a very early start at 1 A.M., doing a long journey of fourteen hours that brought him into Yo. At first sight Yo does not impress one very favourably, for it 
looks little more than a dirty village surrounded by a thorn fence that shuts out a dusty country, devoid of any grass. On rising ground to the south of the town there is a really excellent house, built by the Kachella for the use of the white man. The Kachella of $\mathrm{Yo}_{0}$ is a Kotoko, named Kakami, the son of a chief under Kiari, the Kanuri sultan, who was father of the present Shehu of Bornu, and whose story will be told in a later chapter. Kakami's father was slain in the battle where Rabeh took the Kiari prisoner. His son, whom we shall shortly meet at Yo, was made Kachella by the Shehu, as being the only man strong enough to stand up against the Tubus who are for ever raiding across the border. He is allowed to keep part of the spoil that he takes from the enemy, and while I was at Yo I saw six camels and a number of ponies that told of his success in a recent fight. $\mathrm{He}$ is a powerful man, about thirty-five years of age, but his adventurous life makes him look much older. With simple tastes and possessing few wives, he is always ready at the call of duty. He is a splendid fighter and leader of men and has been hit more than once by poisoned arrows. Great admiration for, and loyalty to, us are very strong traits in his character. In fine, he is by far the best native chief I have ever met in Africa, and his strength and courage, modesty and gentleness, his loyalty, and lastly the deeds in which all these qualities have shown, make him worthy to live in our memory as a hero.

Gosling spent a week this time at Yo, getting all the trade goods and stores checked and put in order. He also did a good deal of hunting, and his notes record meetings with a varied lot of game, including Senegal hartebeest, the 
white-rumped and the red-fronted gazelles, hyena, and a red monkey new to science.

On October 12 he and José left Yo with one of the boats and a week's provisions for Bosso, nine miles from the river mouth, and twenty-one from Yo. A remarkable number of cattle were seen along the banks, and it was a pretty sight to watch them swim the river. Also large flocks of guineafowl were met with, and the river was literally swarming with fish, that banged against the sides of the boat and leapt out upon the banks in their panic to escape the great white monster.

On the journey from Bosso to the Lake, Gosling came upon a hippo, asleep in the grass by the side of the river; so he and José got out of the boats and returned to stalk it. Two or three bullets in the head were required to roll it over. Two hours from Bosso the bush ceases, and the river widens somewhat as it flows through the open country past steep banks, 6 to $8 \mathrm{ft}$. high, on both sides. Half a mile from the Lake the river divides into three narrow channels. Following the one to the south, the boat finally went aground in the shallows a few hundred yards from the Lake, and close to a Buduma canoe, the crew of which were induced to lend their help to push her off again. The water in these channels was nowhere deeper than from 3 to $4 \mathrm{ft}$. Across the river mouth there is a narrow mud-bank that has been caused by the opposing influence of the river current, and by the tide from the Iake when the prevailing winds set in from the north-east.

The evening of October 13 saw Gosling camping on the shore of Lake Chad, which stretched away in a broad sheet 
of silver to the south, beneath a sky of tender green, while behind him the sum set with a glorious flare of crimson.

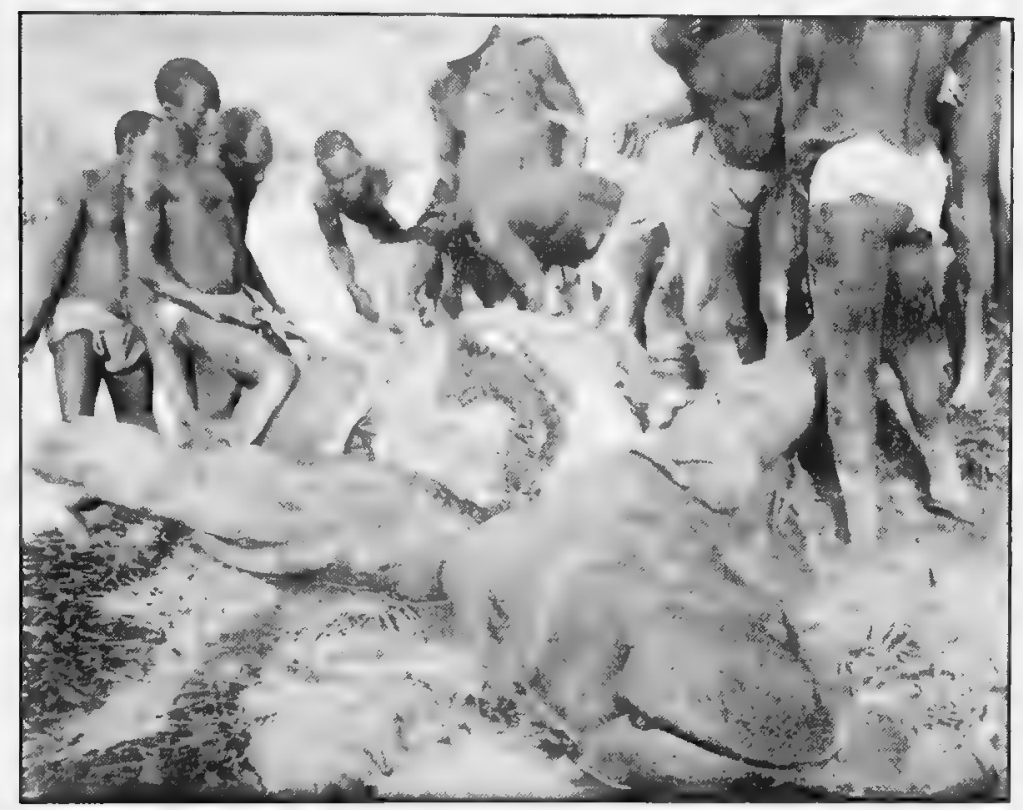

CLTTING UP A HIPPO

José had returned with the boat and towed the hippo into camp. This was presented as a peace-offering to the Budumas, of whom there were a good number fishing round the river mouth. A week was now spent in making excursions on the Lake, and in trying to collect information from the Budumas. Both seemed to promise great results, but both were deceitful; for the attractive expanses of water would lead for miles, only to land the boat in impenetrable mud; while the information given by the islanders, on the rare occasions when they did not run away, was always systematically incorrect. During this time, however, (rosling succeeded 
in getting a useful number of Chad fish towards his collection. One day on the return journey a 6 -lb. flat fish made a tremendous leap out of the water and landed on his hat, falling thence on to his teapot and breaking the handle.

On the 18th a messenger came in from Maidugari with a letter from Talbot, telling the bad news that my brother was lying sick, and asking Gosling to come in and help Talbot with the survey. Accordingly, he returned at once with the boat to Yo, where José was left in charge of everything, and he got together oxen and carriers for the journey to Maidugari.

His arrival at Yo market, which is situated some distance from the town, was opportune, for six horsemen, who had evidently turned up with the intention of doing a little buying on the cheap, cleared off on hearing of him.

Just before he left on the 23rd, a horseman from the Kachella brought in a letter from me, saying that I expected to be at $Y_{0}$ by the 25th. Soon after, the Kachella returned with his horsemen and saluted Gosling in the fashion of Bornu. Riding at the head of his hundred horsemen in two lines at full gallop, he pulled them up dead in front of him. He had just returned from Pogwa, where he had been to investigate the killing of a Hausa trader by the Mobburs with a poisoned arrow.

While at Yo, Gosling witnessed the picturesque ceremony of a native wedding. The bride who was about to marry one of the Kachella's warriors, hailed from a village on the north bank of the river. Accompanied by her old mother and attired in a voluminous covering that enveloped her from head to foot, she rode upon a pony down to the river. 
Upon the pony's rump behind her sat a little girl, holding a calabash over the head of the bride, who was lifted down at the water's edge. Then, after being disrobed and bathed by her attendant maidens, she was ferried across the river upon a raft of reeds and calabashes, escorted by the girls, who swam alongside, carrying their clothes upon their heads. On reaching the near bank she was met by the bridegroom's friends, who led her to the house of the mallam, close by that of the Kachella. Here the wedding ceremony was performed, and then the little bridesmaid emptied the calabash, now full of cowries which she had been collecting from the crowd of friends and sympathisers, over the head of the bride, for the priest to pick up afterwards as his marriage fee. Then followed a festival of drinking and dancing at the house of her friends which was kept up till a late hour of the night, when she was conducted to the home of her husband.

At Yo, Gosling saw a medicine man mend a compound fracture of the leg. After the wound had been washed, the leg was wrapped round with white cloth, then bound with coarse grass and a number of thin sticks adjusted as splints. The limb was then fixed to the ground with two pegs on each side to prevent any movement. In a case of guinea-worm in the right foot, the sufferer was made to stand with his left foot against the inside of his right knee and his right arm extended to balance himself. In this position he drank off a large amount of liquid butter. It was said that the worm would appear three days after and come out entire.

The medicine man's cure for smallpox was as follows: 
the patient is kept in a darkened hut with cow dung burning upon a wood fire. He is given hot water to drink, and to prevent itching cow's urine is applied, or he may be rubbed with burning sand. Anything cold in the treatment is recognised as bad. A cure should be effected in fifteen days.

Gosling left Yo with a transport of seven oxen on the 24th, arriving the same day at Arrige. On the way he shot two of the white-rumped gazelles, which he skinned and sent back to José the same evening. Thence he struck south along the Lake, and on approaching Kaddai, where there was a Buduma fishing-station, he came upon a party of Kanembus with a large herd of cattle, which at once commenced moving off. Thereupon, he sent a mounted man after them to get information. This had the effect of throwing them into a panic which soon spread to the Budumas, and men and women rushed for safety into the water; for the sight of the galloping horsemen made them mistake the party for Tubu robbers. Eventually confidence was restored, and, although many of the Buduma canoes had made off, Gosling was able to get in touch with the chief, whose friendship he gained with a liberal "dash" of cloth, and whom he prepared for the coming of our boats.

The people of Kowa, a town two days' journey through the bush south-west of Kaddai, were holding their weekly market when he arrived, and there was a large concourse with about a hundred oxen that had brought down corn to exchange for dried fish and potash.

As the next trek was a long waterless march of eighteen miles to Bré, Gosling pushed on the same night, arriving there at four o'clock in the morning. Thus, he had done 
thirty-five miles within twenty-four hours, nor did his beasts show any signs of distress. The night was unusually cold and he had been marching in his shirt sleeves, so he spent the time till sunrise sitting over a huge fire. While having his meal, a little deformed boy, suffering from fever, was brought to him for treatment, which, I doubt not, was more humane than that which he himself saw being administered by a native at the same time to a bullock with a sore back. The cure was a red-hot iron! Poor beast! but, like the lobster and boiling water, he has had to get used to all manner of hideous sufferings at the hands of his black master. Here is a note in Gosling's diary. "I saw a man to-day beat a tired bullock unmercifully, and then bite its tail with his teeth, both without effect." But no animal comes into the life of the native without suffering; for the black man has not the faintest glimmering of imagination that could make him realise its pain, nor has he the consciousness of beauty in the animal that in us creates a love of making pets. His dog is either used for hunting or for eating, and picks up its existence as a pariah about the village. Certainly, his horse is a little better treated, but that is because a showy horse enhances its master's reputation in the eyes of his fellows. I have often seen oxen or donkeys in a caravan being beaten along under loads tied to backs that were one mass of raw and bruised flesh. The only animals I have ever seen natives take a pleasure in are monkeys, and then only to tease them incessantly for their own amusement. Consequently, the white man's habit of keeping pets is a thing they fail to understand, and one has to keep a very sharp look-out on the "boys" into whose charge the animals are given, 
else sooner or later, a tragic tale of suffering and neglect will be unfolded.

At sunrise Gosling was upon the road again and a march of seven miles brought him into Kukawa. The Shehuor Sultan of Bornu-on learning of his approach, went out with all his retinue to welcome him, but unfortunately took the wrong road and missed him. Here he stayed two nights to collect fresh transport animals, which were obtained with very great trouble, and then six miserable ones were all that could be got, and one of these had a hole right into its ribs.

Next day the Shehu, gorgeously attired and surrounded by a mounted guard, came to pay him a visit and Gosling gave him a present of cloth and two plates embellished with portraits of the King and Queen, with which he was immensely delighted. This day a letter arrived from Talbot, asking Gosling to go on to Maifoni, as he had not been able to continue the survey towards Kukawa, owing to my brother's illness; but he reported that the latter was improving slowly. Accordingly, Gosling set out the following morning on a ten hours' march to Mongonnu. The effort knocked up the wretched oxen, and he was obliged to wait till late the next day to collect fresh animals. Only two were obtainable, but fortunately three camel drivers volunteered the services of their camels as far as Maifoni. These turned out a great success and soon walked the oxen off their legs, and the latter had to be changed once more upon the journey. Wulo was reached at midnight, and soon after a runner came in with the very bad news that my brother was dangerously ill. Leaving at dusk the 


\section{THE JOURNEY OF THE BOATS TO YO 181}

ncxt day, Gosling arrived at Masu late the same night, to find that a change of horses he had arranged for had failed him. While cantering along in the dark his pony went head over heels, bursting both girths and nearly breaking his collar-bone. The game little animal had done sixty miles in the twenty-four hours. Maifoni was reached at 7 A.M. on November 2. 


\section{CHAPTER IX}

\section{MY JOURNEY FROM LOKO TO DORRORO}

OF course it was a sad day for me when I saw the last of my companions, and realised that I was obliged to spend some weeks of comparative idleness before I would be able to rejoin them and do my share of the work in our forward movement. Still, it was a satisfaction to feel that with such able fellow workers, in spite of the severe checks caused by illness-for I was not the only one to be attacked by the hidden foe-the expedition would now go forward again as if nothing had happened.

My brother, not then fully recovered from his severe attack of fever, had come down to me at Ibi on the news that I was dangerously ill, and there he stayed with me till he received word from Talbot, who had been prostrated at Wasé with dysentery, that he was well again and able to continue the survey in the Murchison range. This welcome news was the signal for my brother to join Talbot, and I saw him off two days before the boats left. He took with him an escort of fifteen soldiers and seventy carriers, who were laden with grain, which he had been busy collecting to carry them through the work in the Wase district, at this time stricken with the direst famine, the result of the failure of the harvest. The famine was rendered more acute by the hostility of the pagan tribes of the neighbouring hills, whose 
outrages had caused a punitive expedition to be sent against them, a cruel necessity that always paralyses a country for at least two years.

On July 1 I left to go down the river in a Government steamer to Lokoja, in the hopes that the change and better food and comforts, which one is able to get there, would pick me up. Also, I wanted to see the P.M.O. and have a thorough overhauling. He made a beautiful coloured slide of my blood for the microscope, which revealed the fact that I had been terribly sapped of strength by the little black demons of the fever. The use of the microscope, recently instituted in the medical practice of the country, is an incalculable boon; for, the microscope is a very powerful engine in the battle against African fevers. By an examination of the blood a doctor is at once able to tell whether a patient has malaria or not, or on recovery, how far convalescence has progressed. I remember once at Maifoni, Dr. Blair, who was making a chance examination of me, predicted an attack of fever two hours before I should have been aware of it, and so by the prompt administration of a dose of quinine did better than cure me later on.

But to return to the events of which $I$ am now writing, a pleasant month was spent by me at Lokoja in the house of Major Merrick, whose kindness and good fare were better than medicine, and each day I was happy in the consciousness of returning strength. Besides my desire to complete a cure, another reason had determined me to return to Lokoja. I was anxious to turn the time passed upon any route, by which I could overtake my companions, to the best account by choosing one which would promise the most interest to the explorer. 
Accordingly, I fixed upon a course through the Keffi and Panda Hills, which form the western end of the mountainous plateau of Northern Nigeria; partly because I had already worked the Benue region, which might be considered the high road eastwards of the Senegambian fauna; and partly because a mountain region always appeals to the zoologist for the chances it affords for the discovery of rare and local forms. Besides it is less likely to have been touched by former travellers owing to the natural difficulties that are placed in the way of exploration. I took with me an escort of two soldiers and thirty-two carriers, whose numbers I purposely made up half of Nupes and half of Hausas; races who cordially dislike one another, and so exercise a wholesome check on each other with regard to such irregularities of conduct on the march as all carriers are prone to commit when in the service of the white man. A Hausa guide-interpreter also accompanied us. He, like almost all native interpreters, required a lot of looking after. They are, as a race, clever and cunning, and by their gift of tongues and a power of flattery and simulation hold the white man, who does not understand the native languages, in their hands, using their position of spokesman to abuse the authority that it gives them and commit all kinds of extortions and blackmail upon the natives. So, an interpreter will go to the chief of a village to arrange for a "dash," and demand in his master's name, perhaps a sheep or goat, or the loan of an even more precious possession, which he secretly appropriates to himself. Of course, this does very grave harm to the name of the white man, who consequently comes to be regarded as a cruel tyrant by the natives. Meanwhile; 
the interpreter, whom it is extremely difficult to detect, waxes fat on his ill-gotten gains, and buys horses and wives and assumes the position of a "big man."

They are highly paid, earning $£ 3$ a month, big money for a black man, but this fact would not have accounted for one, Amadu, who came to us at Ibi possessing little more than the bernouse upon his back, being by the time we reached Kaddai the owner of several changes of fine clothes and wives and horses. We did not trust him, but though he enjoyed our favour, hanging on at times by a very thin thread, he was clever enough to escape detection. José's knowledge of Hausa and his position, which gave him the opportunity of keeping the men under close observation, acted as a wholesome check on fellows of this sort later on when the Expedition was more together.

My remarks upon interpreters apply also to any black intermediary between the white man and the natives, such as tax collectors or resident's clerks. And here I would urge the importance of all Government officials being obliged to pass an examination in the practical use of Hausa, or whatever may be the lingua franca of the colony. They would then not only have more power to check the abuses I have mentioned, but they would also come to understand better the character of the natives and gain their confidence. I remember a case which came under my notice in the Gold Coast Hinterland, where the native agent of a High Commissioner, who was visiting a new country to hear complaints, sat with a bowl by his side into which the suppliant dropped money for a hearing. He also levied a tax on all cases of 
property recovered through the instrumentality of the High Commissioner.

Even in the case of a feud between two big men, that is brought for settlement before a High Commissioner, it frequently happens that the case is so stated by the interpreter that the man who pays him the biggest bribe, irrespective of his right to justice, always wins.

These abuses are always more serious in a new dependency such as Bornu, where Residents know practically nothing of the Kanuri language, and the rascally interpreter can lie recklessly without fear of betrayal. In the older provinces where Hausa is spoken there are officials to be reached who do understand. Besides, it is pretty certain to be the case that the interpreter has plenty of enemies, who are ever ready to inform against him; consequently he has to move warily.

On July 28 I left Lokoja, going by steamer a two days' journey to Loko, a native town with a large market, on the right bank of the Benue, where caravans come from Kano to gain the artery of the river. From here I had determined to strike inland to the hills. There was a detachment of troops on the boat going up to the Gongola region on patrol duty. With them was the usual crowd of boys, who, when allowed, are always to be found in the train of the native soldiers, for whom they act as domestic slaves, in consideration of the chances they have of looting when in their company. In this part of Africa the boys and carriers dearly love looting ; in consequence, if ever there is a military expedition afoot, there is no difficulty in getting carriers. I remember that when my brother's column started for the survey in the 
pagan country North of Ibi, which promised the most attractive opportunities for the indulgence of their propensities, we had the greatest difficulty to drive off the many parasites who fastened on the column. As I was short of carriers, I took on two of these boys who, believing that they would have even better opportunities of looting with me, were glad to come. But it was not long afterwards that they discovered their mistake!

I started on the march late in the afternoon of July 31, only going two hours that day, which brought me to camp near a dirty little village, called Washi-on the lucus a non lucendo principle I suppose. Still, the hut that the chief gave me to sleep in was clean enough, and I was glad of its shelter, as it saved time the next morning that otherwise would have been spent in striking and packing up tents and baggage. This was the rainy season, when there was always the chance of a tornado coming on to break one's night's rest and, perhaps, the tent as well. The distance was very small that we had covered this first day, but one is always prepared for a bad start from any large town, for the "boys" are demoralised by the dissipations of the market, and one is thankful enough if the first move does no more than shake off the dust of the town and enable one to gather one's forces together for a better start on the morrow.

Next day, in spite of an early start, we accomplished only half a day's march, for I felt an attack of fever coming on, and therefore decided to stop and camp; this time well outside the village we had come to, which was even dirtier than the last. That night I had a rather bad time, aggravated by a tornado which broke with great force driving 
the rain into my tent. So I lay abed all the next day and night to shake off my fever and gather fresh strength, recommencing my journey early on August 3.

The country through which we were passing was flat, covered with low bush and stunted trees, and intersected with a number of streams with banks thickly wooded with tropical growth. The streams, mostly about twelve feet wide, were much swollen by recent storms, and we waded through them, the water reaching as high as the thighs. The evening brought us to Giddan-Duci (the houses by the rock), a pretty little village nestling at the foot of a thickly wooded, rocky hill. The aspect of the landscape now began to change, for we had been gradually ascending, and from the high ground a larger view was obtained. The monotony of the bush was broken by the sight of glades dipping into its surface, and here and there by a tall, lonely cotton-tree, which was clearly defined by its white stem and branches. Occasionally appeared the dark green blot of the umbrella-shaped tree that always marks the gossip-ground of a little village, where the old king sits and calls up the passing wayfarer, bidding him tell the news of the road he has come.

The country began to be undulating, and ahead of us to the north-east little hills appeared in the middle-distance, lonely stragglers, growing more frequent as they receded to the horizon where they joined the blue mass of the Keffi Hills. At Giddan-Duci, round the foot of the hill, the inhabitants had tilled the soil which was growing rich crops of guinea corn, and of monkey-nuts which have bright green leaves, like the trefoil, close to the ground. These fields attracted a great deal of bird life, and little flocks of glossy 


\section{MY JOURNEY FROM LOKO TO DORRORO 189}

starlings were to be seen, which, like our own, hang about the haunts of man with aggressively familiar bearing. The

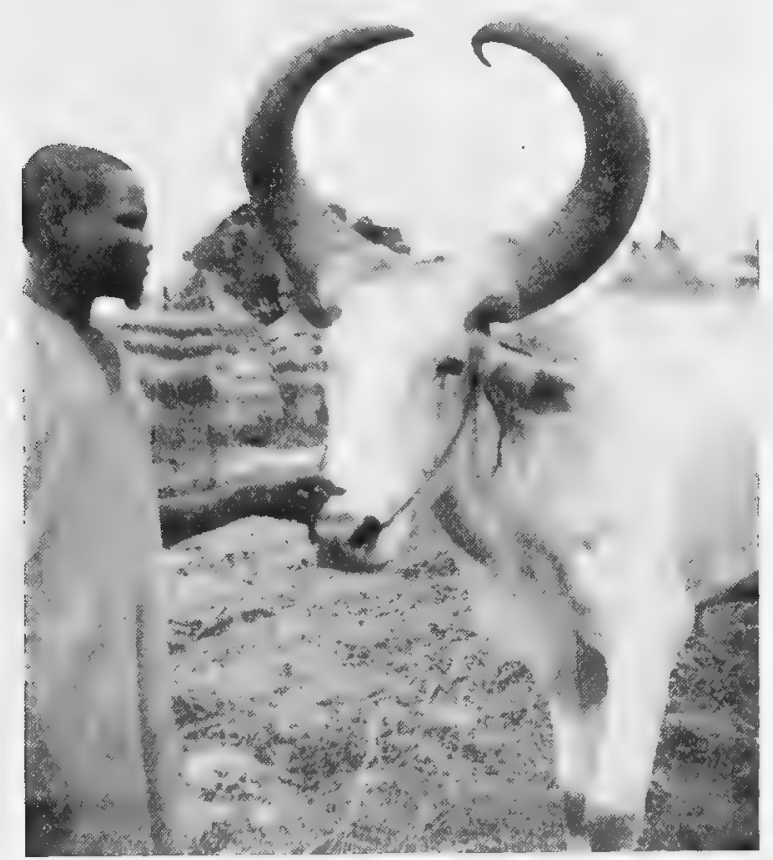

A FULANI OX

shy thrush and shyer redstart, too, came down to the plots under cover of the bush. A pair or two of black-and-white crows held points of vantage on tall trees by the village. Every hamlet seems to own at least a pair of these birds which act as scavengers and are treated as friends by the natives. In an ornamental way, they rather share duty with the pigeons, imitating their ways of wooing with comic effect, for their ungainly bows and scrapes and rattling love-notes are a caricature of the more romantic birds. 
On August 5 we arrived at Nassarawa, the trade centre and capital of the province of that name. It is a large town, peopled with Hausa and Fulani, but it has the gloomy appearance of a place that has seen better times, with houses deserted and dilapidated, and the corners of the streets thronged with beggars. The great walls, once the pride of kings which required the labour of thousands of slaves to build and keep in repair, are now crumbling away and subsiding with neglect and successive seasons of rain.

In the days of slave-trading Nassarawa was a flourishing city with a powerful Fulani king and many big men, who owned large herds of cattle and sheep and great numbers of slaves to tend them. It was under the dominion of the Sultan of Sokoto, to whom its people had to pay an enormous annual tribute in slaves. But, with the abolition of slavery their wealth has gone, they can no longer keep up the large numbers of their herds, and the big men attended by only one or two personal slaves sit in empty houses, mere shadows of their former greatness.

The Fulani are an interesting people of Eastern origin, who are believed to have settled in Egypt from farther East, and to have been driven out of their adopted country during the Theban Dynasty, 2500 years ago. This is the opinion of Mr. Morel, whose learned and convincing speculations on the probable history of the race I found borne out by all the observations I was able to make. Being the owners of large herds of horses, cattle, and sheep, it naturally followed that the Fulani would take a course where food and water would be most easily obtained for their beasts, so, doubtless, by the way they came they avoided the desert as much as possible and 
followed the more or less fortile lwelt af hush and rivere that

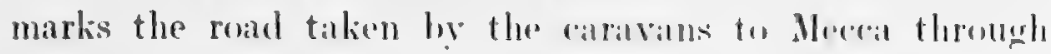

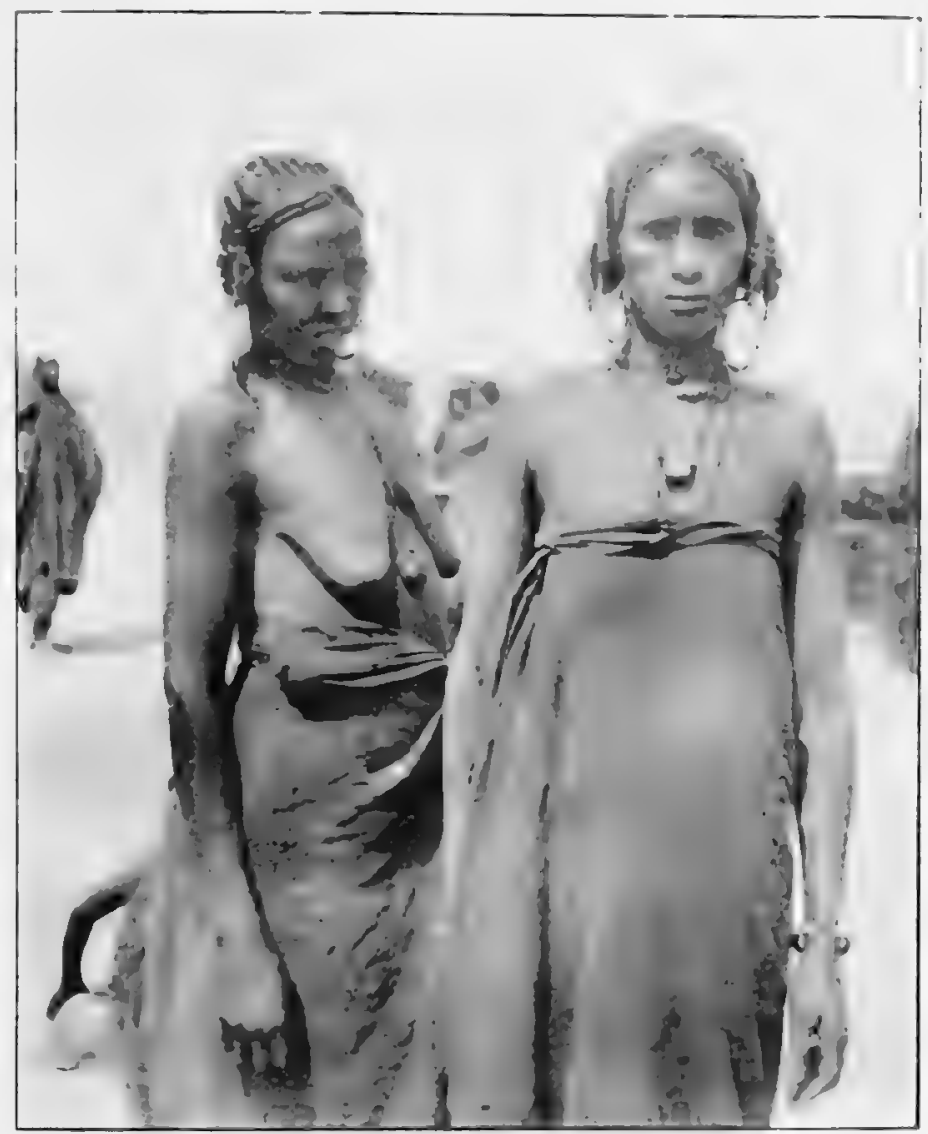

BUSH FULANI

the rentre of Africis till there found themselves at length in the fertile plains of Nigeria.

To horsemen like the Fulani, the more intentle prople of the plains fell an easte conquest. whild the hill triluss, whome natural stromgludk presented grrater difficultios anainst 
attack, were left unconquered by them, and to this day the pagan tribes have preserved their characteristics unchanged, and have remained hostile to the entrance of the stranger into their country. Whereas, the Fulani, finding the tribes of the plains tractable to their rule and their country fertile for corn and rich in grazing, established themselves and raised large herds. Thus they soon became rich and powerful in the land and settled down to a life of ease, surrounding themselves with horsemen and many slaves, and raiding the neighbouring tribes for wives to fill their harems, much as the Romans conducted the rape of the Sabines. So they increased and multiplied, and their priests established schools for the spreading of the Faith. As the generations went on, the area of their power was extended and more tribes came under their influence, who in their turn gradually influenced the conquerors by the mingling of blood, till the Fulani in possession of the land to-day have become much changed in type from their ancestors. The purest representatives of the old race are now found among the Cow, or Bush Fulani, a disappearing people, who live entirely in the bush, wandering in small bands with their flocks from place to place, seeking the green belts of the rivers when the drought burns up the plains. Probably these are the descendants of the slaves that came with the first exodus as horse-servants and shepherds of the flocks, for they would not have shared in the spoils of the conquered nor have grown rich enough to buy the strangers for wives. So, keeping much to themselves and living their life among their master's herds in the bush, they not only preserved their original type, but, with each succeeding generation their lonely habits became more and 


\section{MY JOURNEY FROM LOKO TO DORRORO}

more merged into their inherited natures, till perhaps a day came when their masters seemed in their eyes an alien people, whose grasp had weakened with generations of ease and luxury, and they organised themselves and broke away, driving off what cattle and sheep they could collect in their hurried flight into the bush, where their long knowledge of its windings made it easy for them to confound pursuit. And perhaps, too, they became even a source of trouble and dread to their former lords, who starting up in the night at a distant low whistling might hear their bulls, bewitched by the magic of the sound, stampeding and clearing their bounds to join their old drovers in the bush.

This power over cattle, begot of generations of intimacy between man and beast, the cowherd tending his herd by day in the pastures and lying down with it in the bush by night, is common to all the Fulani, and to all the pastoral peoples of Bornu; a fact which, as Mr. Morel points out, largely strengthens the idea that their origin is traceable to the East. In my own experience, I have heard the distant whistling round our camp at night, to find in the morning that some of the bullocks, collected for us by the local chief, had broken their tethers and gone away.

In Bornu it is a frequent and pretty sight to see a herdsman and his boys sheltering from the heat in the shade of $a$ big tree, while, away beyond the open stretch of sun-stricken plain, his cattle wander off into the outskirts of the bush in search of sparse tufts of dry grass, that have survived in the shelter of the scrub. And it is pleasant to hear the longdrawn note of his whistle, and then to watch the beasts 
look up, snuffing at the call, and, following their leader, tail slowly back in line to the herdsman's hand.

Though to-day in peaceful times there is no longer the necessity for their protective habits of aloofness, the Cow Fulani still are by nature shy and retiring. They live in the bush, where they make little grass huts for themselves and thorn zarebas, into which they fold their herds at night. In the markets of the villages and towns, where the Fulani of the plain, and Hausas, and sometimes the far-travelling Arab, and even a few pagans from their hill retreats, mingle in the busy crowd, the Bush Fulani are never to be found. Instead, on certain days they make a market by the roadside or in the bush, where the people of the neighbouring villages come to buy milk and butter. Save for large silver coins which they can beat into ornaments, money is not understood and is refused by them, and primitive cowries are the only form of currency that they use when they do not barter for cloth or beads or salt. They are pale of skin and have hair of fine texture, and their features-especially is this noticeable with the women-have a regularity and delicacy about the lines that instantly recall the more romantic East. So, too, the architecture of the Fulani of the plains, which has preserved its purity of type little changed by its surroundings, has a character and grace of proportion and ornament that are eloquent of an ancient civilisation, and the big men's houses remind one forcibly of Egyptian temples. The Fulani, who are Mahomedans, have by their schools preserved their faith more strictly than other peoples who migrated from the East.

As one passes through the streets of a Fulani town, or 
rests beneath the trees in the market-place during the hottest time of the day, when all labour is drowsing and the little

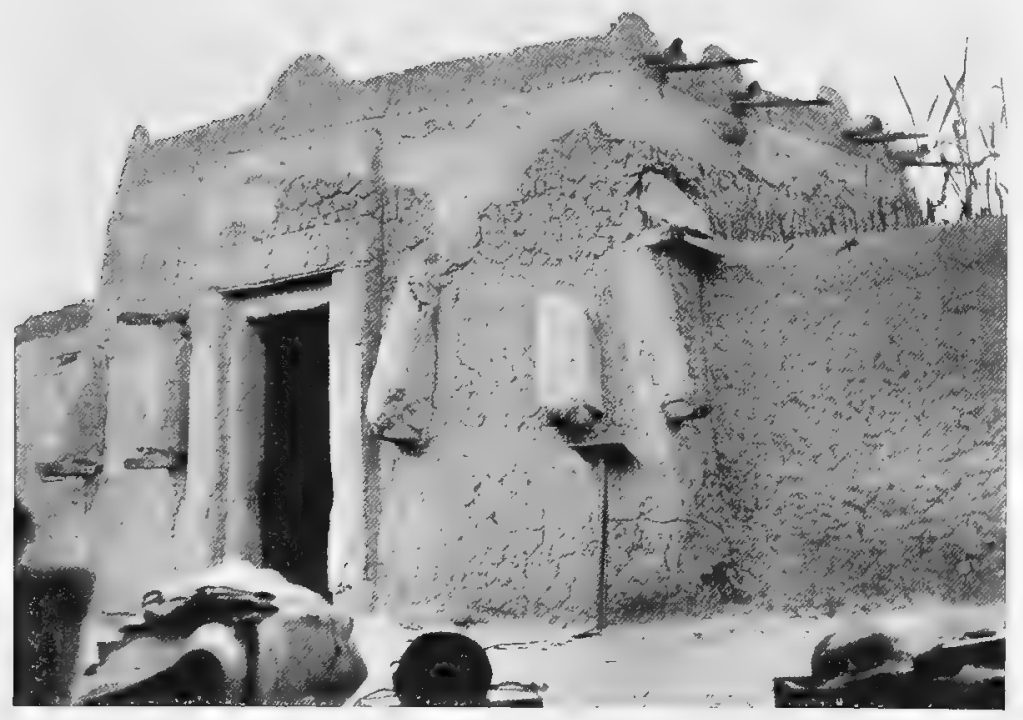

FULANI ARCHITECTURE

children have been freed by their parents from their task of carrying water or working in the corn patches, it is a familiar sound to hear the sing-song of little treble voices in the compound of the priest droning out verses of the Koran through the sun-struck hours, and one's thoughts go back at once to an English village, to the school by the church; for one remembers the sound, it was just the same sound.

The Fulani are at heart no friends of the white man, who has robbed them of their slaves, and so destroyed their chief source of wealth. And this hostile feeling is fostered by the influence of their religion, which keeps their patriotism alive. Some years ago their smouldering impatience of the 
white man's rule was fanned into a flame by the preaching of the Mahdi, named Senoussi, who gained a great following

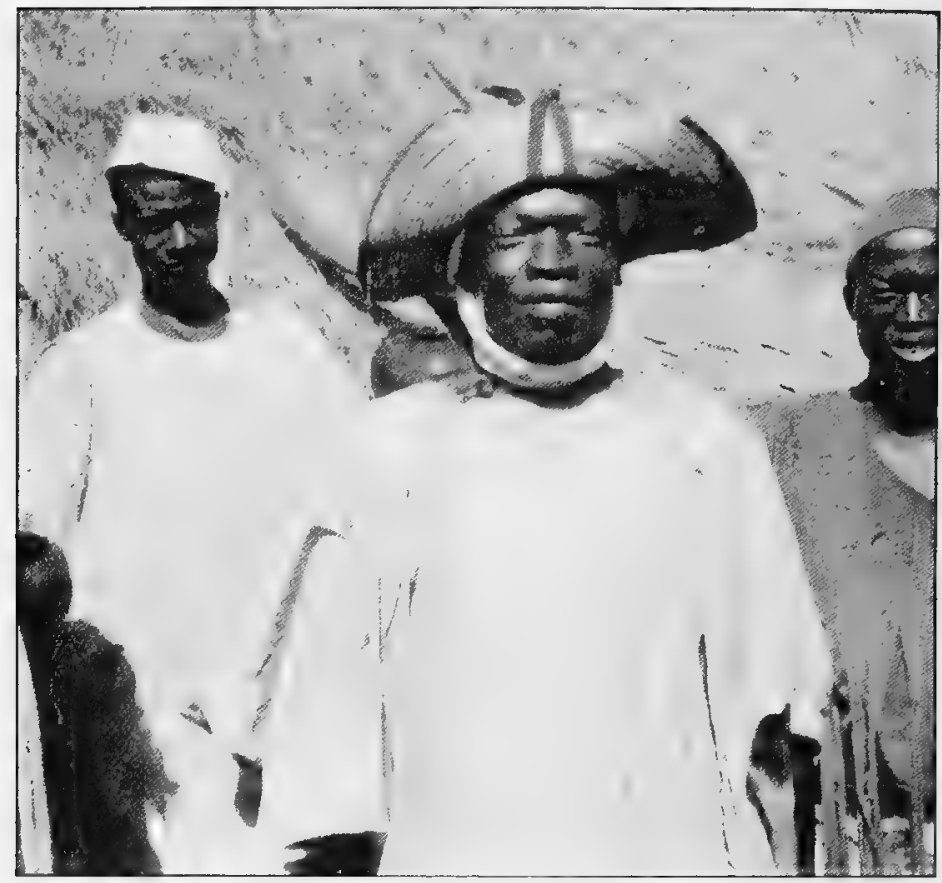

A HAUSA MERCHANT

among the Fulani by prophesying the advent of our dominion over them. But this he told them would only last four years and then it would pass. The allotted span was up about the year 1903, and in consequence there was great unrest and outrages upon white men were committed at the time. These led to the necessity of a punitive expedition being sent out against them, and the walls of their towns were broken down. Consequently, their faith in the doctrines of Senoussi has been somewhat shaken. They now say the white man will some day grow tired of their country, and 
so they wait patiently, believing that one fine day he will pack up and be off.

The Hausas, who form a proportion of the populations of these Fulani towns are older in the land than the Fulani,

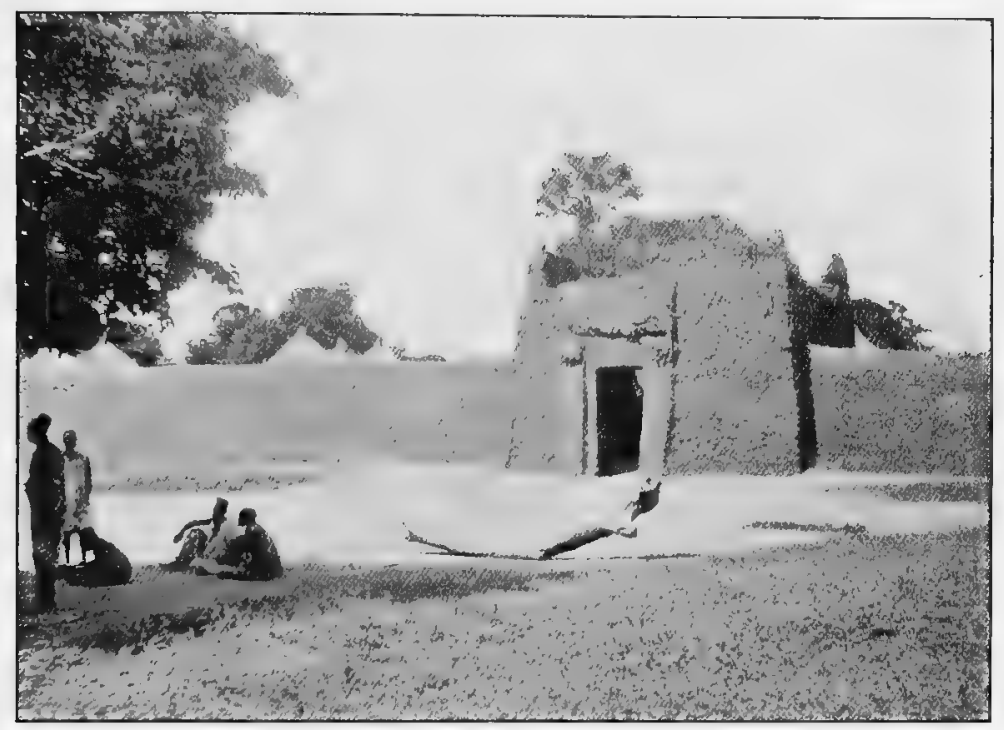

FULANI-HAUSA TOWN

who conquered them. They are most probably an offshoot of the Arab race who have changed under the blood influence of the peoples among whom they have come. They have the Arab's love of travel and aptitude for trading, and are gifted with his cleverness to a marked degree, being by far the most educated and intelligent of the races of Nigeria. Hausa is the trade language of the country, and its derivation from Arabic seems to show in many Arabic words, and in all the numerals over twenty, which it would appear were beyond the usual range of reckonings in the markets and so have been preserved unchanged. Probably their migrations were 
determined by the trade-routes, and they worked from Egypt along the coastways to Tripoli, and then hearing of the rich land in the south, came down the roads of the caravans through the Sahara to trade and eventually to form industrial settlements. Another proof of their Eastern origin appears in their name for the giraffe, an animal which they would have seen for the first time in Nigeria, and which they have called Rakume dage, or the camel of the bush, as their familiar camel was the nearest animal they could liken it to.

At Nassarawa the two boys, whom I had taken on from the patrol on the Lokoja boat, deserted. They were evidently tired of steady marching without the compensation of occasional looting, and disappeared without waiting for the pay that was due to them. But first they carefully laid all the things that had been entrusted to their charge in a prominent place in my house, for fear, in the event of the things getting stolen, they might be suspected and pursued; such a belief have they in the consequential nature of the white man's justice.

Mamadu, the king of Nassarawa, received me well with a generous "dash" of the customary fowls and eggs and calabashes of milk. Also, he placed a good house at my disposal and showed that he had a knowledge of white men, by sending up by his women great jars of water immediately upon our arrival. So I returned his hospitality by giving him a performance on the gramophone, which was received with awe and stony wonder, till a rollicking laughing song set the mouths of king and courtiers agape and grinning, and echoing ripples ran round the circle to break, as the fellow in the machine got away with the chorus, into shouts and 


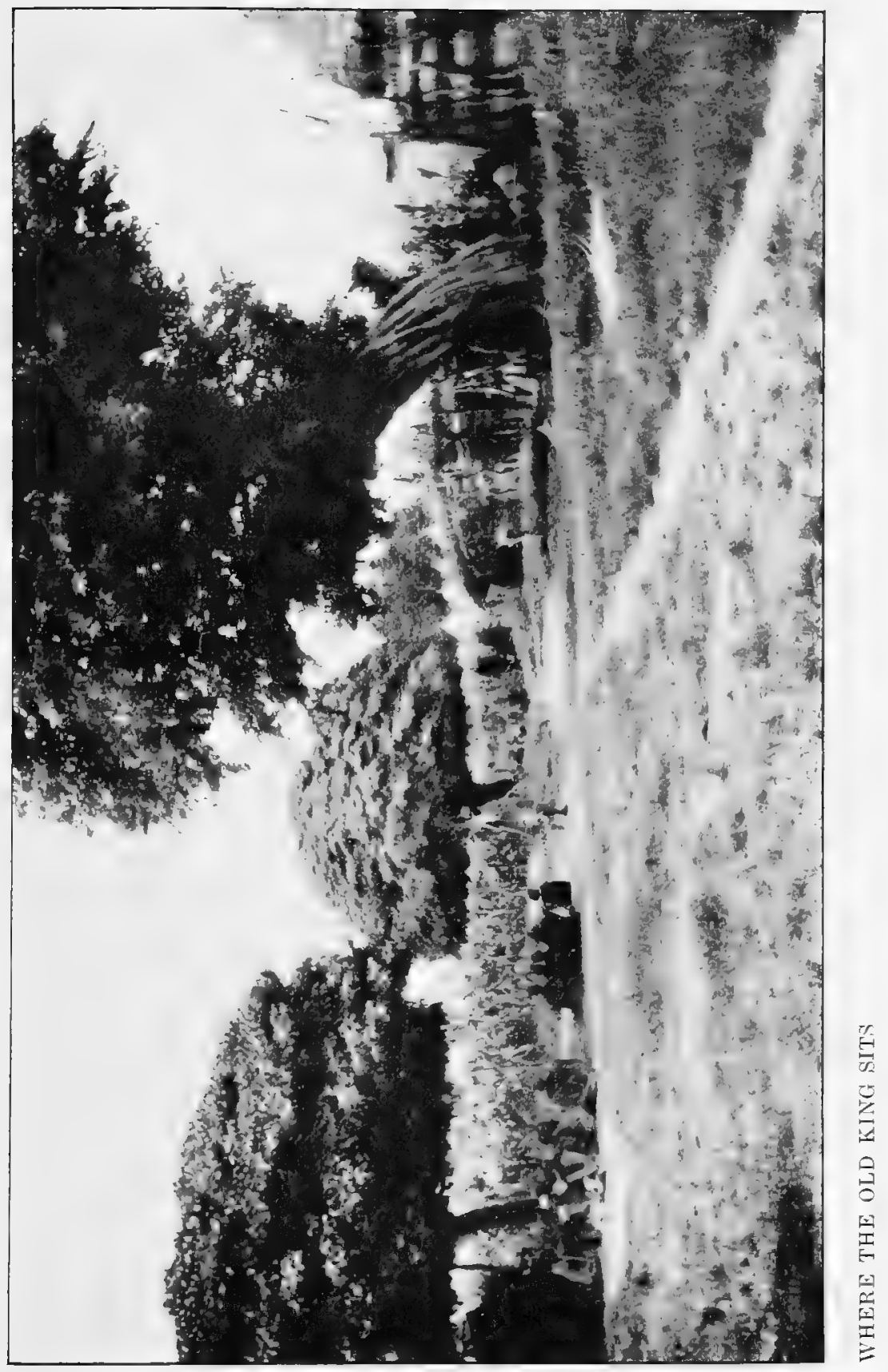


howls of laughter. Then king and courtiers forgot decorum and fell over one another, slapping backs and thighs as they rolled about and writhed in exquisite convulsions.

I then produced my phonograph and told the king that if he would speak a message to the King of Dorroro, the next place I was going to, I would capture the pearls of his eloquence and convey them to his ally. Accordingly, he spoke a royal message of salutation, and, when a moment afterwards the machine repeated it, one might have thought by the awe-stricken silence with which he listened that I had imprisoned the very tongue of his utterance; till the shouts of approval from the people round dispelled his fears, and he joined in the general chorus of delight.

I made a very successful record also of the long brass trumpets that were sounded before this king on his progress through the villages of his country. They were rather like our coach horns in shape; sounding two notes that rose and fell, soft and deep in tone like those of a hautboy. Unfortunately the record was spoiled by damp before I could send it home.

We stayed two days at Nassarawa, much to the delight of the "boys," who dearly love to hang about the markets of the towns and received the news of our staying with the joy of schoolboys who have been given an extra "half." When the "boys" did well on a march I always made it a practice, if convenient, to humour their little weakness, for it put them in good temper, and they always did the next trek better, with a dog-like gratitude for past favours. It was amusing to notice the simple, artless tricks by which they attempted to guide destiny in the shape of their master. 
Invariably just before a town was reached some would start game legs and limp painfully along. On this particular occasion Lowi adopted other tactics and came to tell me that there was "plenty wash"; which meant he would advise our patronising the local laundry and so wait the time necessary for our linen to be got up.

The next place we stopped at was a dirty little village called Laminga, ruled by a mean old chief, who sent me out a "dash" of two pigeons and four eggs. The former were too young and the latter too old for my liking, so I sent them back to him with a message as bald as the pigeons and as pungent as the eggs. This had a good effect, for the chief came out himself with two fine fat pigeons and some milk and yams.

We left Laminga early the next morning, following the road through undulating country where each succeeding crest marked a gradual rise, till after four hours' march the top of a ridge was gained, whence Keffi appeared midway up the slope of the next hill; a long line of white houses surrounded by strong mud-walls. Keffi was once an important city before it got " hammered" by a British expedition, which was sent to avenge the murder of Captain Maloney in 1902. The Magaji of Keffi had been causing trouble, and Maloney, contrary to the warning of his men, impulsively entered the former's house where his women were. This breach of native custom infuriated the Magaji and he caused Maloney to be set upon and killed with spears. A mud wall that crowns a little green hill above the town is said to mark the place where his bones rest.

The houses of Keffi are large and well-built. I stayed in 
the Magaji's deserted palace. In the centre of one of the rooms, about $20 \mathrm{ft}$. high, there was a huge circular granary that rose right up to the roof, reminding one of the furnaces in a Kentish oast-house.

From Keffi we left the main road, following bush paths in a north-easterly direction. That day we had to wade through many swollen streams, and four hours of this sort of travelling was long enough, so we pitched camp at the next small village. The rains had now settled in with steady downpours, which made travelling heavy work, what with our frequent soakings in the streams and the sodden campinggrounds. My work of collecting was also hampered very much, and it was a troublesome matter to preserve the skins from the wet. Four days more of this not very pleasant travelling brought us to the eastern end of the Keffi and Panda range, the watershed of the Gurara and Kaduna rivers. The former rises on the northern slopes and the latter on the southern, both falling into the Niger before its confluence with the Benue. The path now rose and dipped up and down pretty hills, and followed the curves of the valleys across the lines of green luxuriance in the hollows, where wound swift-running streams, which spread into marshy pools covered with a glory of lily cups, some white, some a Wedgwood blue and others blue slashed with pink. It was along these green-shaded watercourses and round the lily pools, in that enchanted hour at sunrise when Earth seems exhaling the fragrance of the just-departed fairies she has couched, and again when day pauses with drooped eyelids to catch the sound of night's soft foot-fall, I heard for the first time the entrancing song of the red thrush. 
More lovely in voice than the nightingale, more shy than she, his song seems the soaring spirit of the haunts in which he dwells ; first, whispering notes like little puffs of wind through green leaves; then a soft soliloquy of liquid sounds like the stream that runs below his singing-bough, so sad that it is surely here beneath these waters that Narcissus lies. Quicker and louder mounts the song, to break in long notes that swoop and thrill with a passion that is all the sweet bird's own. Hours have I watched to catch sight of the maker of such pure music-but never to see more than a flash of red in the interval of silence before the fountain of song started to shower again from some fresh-enchanted tree-until I almost came to believe that it was a spirit bodiless, and to think it most right that a voice which could interpret the heart-beat of Earth, should be too great to dwell in a tenement more confined than the air. 


\section{CHAPTER X}

\section{MY JOURNEY CONTINUED TO ASHAKA}

AT length we reached Dorroro, a town lying in the valley at the foot of a lofty hill with a square-topped head. Between the city and the hill there runs a river, which serves as a line of defence for the more peaceful inhabitants against the fierce tribes of the hills, whose pastime it is, when they get the chance, to swoop down and cut off the labourers, as they gather nuts in the palm groves, beheading the men and carrying off the women and children.

I was well received by the king, who lodged me in a fine house and supplied me with plenty of food. In the evening I set up the phonograph with much ceremony, and bidding him listen attentively, told him that a friend desired to greet him. At the first few words he recognised the voice of his ally, and with no more than a gesture of ordinary surprise, as if to say, "I didn't know you were here," he stood up and looked busily about him, over the heads of my "boys," quite expecting to find the King of Nassarawa there. When I assured him his friend was not present, but that I had captured his voice and held it there (tapping the box), his face became a picture of fear. I am sure that at the moment, he regarded me with more dread than his enemies, the fierce Kagorras over the river. For it was evident that I was not only a head-hunter like them, 
but also a witch-doctor who had the power to keep the heads alive. Nor was he at all easy about his own head, till I had taken a record of his voice and reeled it off to him. At that he was amused; also he appeared to enjoy my.gramophone performance thoroughly, but all expression of wonder seemed to have subsided with his fears. This is always a disappointing experience with regard to one's attempts to impress the natives with the marvels of our inventions. For our physical powers they have a contempt that is reasonable, and for our mental ones respect, and very little more. They have not the imagination to measure the wonder of an invention by the difficulties overcome in its achievement. Their knowledge of things is shut out at a certain point as the day is shut out by the night, beyond that is darkness and white man's land, and in that region they accept without surprise anything that a white man does. They have made up their minds long ago that the white man can do anything that he pleases in witch-doctoring, a term for them including all things that are not to be understood. So they cringe to the user of these unknown forces as dogs cringe to their masters ; and, like dogs, they do not marvel at him.

Next morning I went out reconnoitring to find a path into the Kagorra country, as I was anxious to find out a little about its inhabitants, who, by all the accounts I could glean of them, seemed to be interesting. But I had not been long gone before the King of Dorroro and his horsemen with much commotion galloped after me to prevent by persuasion, backed by a friendly but firm show of force, my carrying out my intention. For he said that I would 
certainly be killed by the Kagorras, the more so as one coming straight from himself, who was their hated enemy; and he pointed to the ground by the river which was their battle field, saying that many on both sides had been killed there. And he added, that should any evil befall me, my death would be avenged by the British Government on him. Accordingly; for the present I left the hills alone. These run on the whole way to Badiko, which is five days' journey west of Bauchi.

A day's march brought us to a village called Koninkum, where the natives at first ran away, as they had heard the reports of my collecting-gun and believed I was coming with force against them. After a time I managed to persuade them to return, but I might have spared the pains, for I could get nothing out of them. They were a dirty lot, inhabiting small round huts which, if anything, were filthier than pig-styes. In these a gangway, through the first half, divides four little stalls where the children sleep, and the back half of the hut is given over to the men and women, who sleep huddled up together, naked, like pigs. The entrance is so low that one has to go on hands and knees to pass. Needless to say, I did not seek my night's shelter in one of these dwellings, but gave the village plenty of room, and in heavy rain cut a clearing in the long grass for my tent.

Next day we came to a deep rushing river with so strong a current that it was impossible to cross. I first tried to throw a rope bridge over, but the "boys" could not hold on and were washed off by the force of the water. Luckily there were fine trees growing thickly along the banks, and so I was able to make a bridge by felling trees to fall across. 
Two days from Koninkum brought us into the KachiPanda hills, where lives a pagan tribe which does not recognise marriage customs. Only leaves are worn, or many of the women wear nothing more than a curious ornament, which is cylindrical in shape, about 8 in. long and made of twisted rope. When the ornament is encased in brass, it denotes virginity. It is hung down over the lower part of the back and kept in position by a string round the loins. It has a quaint effect and at a little distance gives one the impression of a tail. They also use the pelele, a hideous fashion, consisting in two discs of wood, inserted into holes in the upper and lower lips. As they grow older larger dises are used, till, with the old women, the lips are forced out beyond the nose. Their bodies, even those of the babies are smeared over with red clay. In one of their villages a hideous, toothless old hag wearing only her "tail," which was not encased in brass, came out and cut capers before us. Her body, too, was smeared with red, and when I asked her why she painted it, she said that she had lived all her life to please men by her beauty and her dancing.

The villages of the Kachi are situated at the foot of isolated kopjes where they till the rich volcanic soil of the lower slopes and grow good crops of guinea-corn, maize, and ground nuts.

With another two days' marching we arrived at Katab, a fairly large Fulani town picturesquely surrounded by thick groves of cocoa-nut palms. It was on the main road, so had a market where we were able to get supplies of food. Before this, through the Kachi country supplies had been precarious and I had been living on tinned rations. We left Katab 
in the early morning and after a three hours' march reached the bank of the Kaduna river. This proved a serious check to our progress, as we had no proper means for the crossing. The river was in flood with a turgid stream thirty yards wide, flowing with a current of ten miles an hour. At first it seemed very hopeless to think of getting the thirty-two boxes across, as the only native means of conveyance were faggots of bamboo canes. On these the natives sit astride one end, the other sticking up in the air in front, and propel themselves by their legs, carrying whatever burden they have upon their heads. I tried this method with my boxes, but they were too heavy and the experiment resulted in the first box being thrown into the water. I then thought of my canvas bath and this proved very useful for carrying the lighter things. The strongest swimmers among the "boys" managed very well, pushing the bath in front of them. But the problem of the boxes was still to be solved; also there was the transport of my own person to be thought of, for ever since I was nearly drowned as a boy at school I have never been able to master the art of swimming.

Now it so happened that with the rest of my baggage I was carrying a coffin, which had been entrusted to me at Lokoja to take up-country. At first I hesitated at putting the coffin to other use than that for which it was intended. But, after all, it seemed to me that it was destined to be a Charon's ferryboat to carry its mournful freight over a darker Stygian flood than the one before me. And the coffin itself had to be got across somehow. As it was in my charge why should I not go with it? So I placed it upon the water and got in. Luckily it had enough resistance to carry my 
weight, riding the water with 3 in. of rim above the surface. Then, in spite of the warning of the poet who sang:

"Trust not your boat to the cruel tide,

Nor sail in your shell o'er a grave so wide!"

I was pushed out into the current, and the coffin, swiftly carried along, after a few exciting moments, touched the opposite bank at a curve in the river. seventy yards lower down.

It took the whole day to complete the crossing of the river, and the work was very arduous. So we did not march further, but camped by the river-bank that night and stayed all the next day while I explored the neighbouring country for birds.

From this point I struck in a north-easterly direction hugging the foot of the hills, determined not to leave them without a sight of their inhabitants. In two days we arrived at the Petti hill, a fine isolated mass with steep sides rising about $800 \mathrm{ft}$. out of the plain, and strewn with grand volcanic rocks. On the lower slopes there were little water springs, clothed in luxuriant vegetation of bushes and hanging creeper, with here and there fine cotton trees. This cloak of green swept half way up the hill, and then the verdure grew more scant, to fall away from the steep bare sides of its cap of rock. I found a very interesting fauna, peculiar to the hills, with local forms not found upon the plains. There was a pretty little grass warbler and a beautiful rock-thrush, both new to science. The latter has a bright red rust-coloured breast and white shoulder patches, most remarkable when the bird is flying. His movements are 
like the wheat-ear's, in his quick flight from rock to rock and sudden cock of tail as he settles to utter his chattering song. The path I took wound picturesquely up the hill, sometimes climbing, where the side was steep, up steps cut in the rock, at others taking its way by little passes in the boulders, through tunnels of green leaves and natural arches made by fallen rocks, to round a corner and discover a crowd of naked children, who scampered off with cries to the little cluster of huts that were perched half hidden in the green upon a ledge of the hill. These were the dwellings of Kagorra folk-whose hamlets were sprinkled in little groups all over the hill.

These pagan hill people are of fine build, but have coarse and disagreeable features very much like the Munchi, whom they resemble in their scanty costume, the men wearing no more than a conventional covering, and the women nothing at all. They are keen hunters and fighters, using poisoned arrows, and their predilection is head-hunting. They are continually raiding the gentler natives of the plain as they work in the fields, and cutting their heads off. They use small hill ponies the size of Shetlands, by means of which they keep up a perfect system of communication from one hill to another. Their huts are made of mud, cemented on to the projecting rocks, with the floor generally much lower than the entrance. In one of them I came across a row of human skulls carefully polished and strung together; in others there were the little ponies hidden away.

From my tent at the foot of the hill I watched these curious people squatting in groups like so many monkeys and basking in the sun for hours at a time on the great 
projecting slabs of rock. On one's approach they would suddenly disappear into their rock-dwellings.

Climbing up to the top of the hill, I obtained a glorious view of the Nigerian plains. The air was clear after a night of heavy rain, and far away to the western horizon the midday sun searched out every little detail of the landscape, bringing out its features in strong relief. Miles upon miles of corn and millet fields spread over the endless plain, down which a river's course was traced by a broken chain of shim. mering white crescent curves, which died away in the billowing sea of green long before they reached the distant line of silver hills. Clusters of huts like beehives were thickly dotted in the corn. Truly it was a picture of fertility, and I thought what a fair land of promise it must have seemed to the Fulani long ago, when weary with years of wandering they beheld the broad prospect for the first time.

From the Petti Hill I trekked eight days eastward over the outer edge of the hills to Badiko, through a country of luxuriant growth and high grass that choked our path in dense masses on either side. All was dripping wet with the heavy rains, and a few minutes' walking along the narrow paths found me soaked to the skin. Collecting, too, might have been classed as an aquatic sport, and often it was made very troublesome by the thickness of the jungle, which not only concealed the birds but also gave a poor chance of finding them when shot. This was a poor country for game, but (though I had not been on the look out for it) it seems a little strange that neither I nor the "boys" had sighted a single head since we started from Loko.

Half way to Badiko we came into more open country 
in the region of the Gora Mountains. The path was pretty and took its course through the passes of the grassy hills, which, in contrast with the rocks I had not long left behind, had the appearance of rolling downs. Below in the valleys the grass was long, and little streams trickled through green lines of tall bamboos, the first I had seen upon this journey.

The Fulani get tin from these streams, collecting it in quills and working it into ornaments, for the most part bracelets and rings. The white man has now followed on their track, and at a place called Tildi I came across two English miners, who were boring for the tin, but they told me that the lode lay in the mountains to the south, which were impossible to get into owing to the hostile Kagorra.

Next day I came in sight of Zaranda Hill rearing its square head over the western horizon, so I knew that I was not far from Bauchi, where there was a chance of hearing news of the others, and one more day's marching brought us into that town. To my great disappointment I found no word from the Expedition, and the only news I could gather was that my brother had passed through the place some six weeks before.

Bauchi is the most important of all the Fulani towns, and the capital of a large province. It is prettily situated at the foot of a green hill, its white houses mounting half way up the slope. Round all there runs a splendid mud wall, about $15 \mathrm{ft}$. high and $6 \mathrm{ft}$. thick, with a fine postern gate closed with doors of wood, and towers, stair-cased within to look-out posts on the top. It has a large market where not many years ago slaves were the chief commodity. In fact, the word "Bauchi " means "slavery" and the town was once one of the largest slave-markets in the Western 
Sudan. On my arrival the Emir sent me a large "dash" consisting of a sheep and eggs, and a good supply of meal for the "boys." I sent him my thanks and told him that I would pay him a visit the following day. He is a powerful ruler and keeps up a good show of state, living in a large palace built in the Egyptian style which I have spoken of in a former reference to Fulani architecture.

On my arrival at the palace gate, the serikin-fada, or king's messenger, stepped out from a group of big men who were assembled in the shade of a spreading tree, and throwing open the doors of the palace, went in to tell the Emir that I had come. Presently he came out to greet me, preceded by his dogari, or executioner, who shouted in a hoarse, hollow voice the praises of his king; saying what a very big man he was and what big things he had done. The alkati, or chief judge, was at the king's side, and around him stood mallams and councillors and a large retinue. He shook hands with me and then led the way in, passing through a large, lofty hall with a groined roof of mud, so discoloured with age that the arches had the appearance of old oak beams. Then we passed through a courtyard and an ante-chamber to his state room where his attendants let him down on to a mat of skins. $\mathrm{He}$ then proceeded to converse, addressing me as "Big white man from over the sea, bound on a long journey," and "Big man with two big boats and a many-voiced trumpet." I liked the allusion to the gramophone, so I asked him if he would like to hear the trumpet speak, to which he eagerly said "Yes." Then the gramophone was brought out and set to work with most gratifying effect, for his habitually stern countenance relaxed, and he appeared 
quite transported by the inspiriting band music, and picked out the voices in the part songs with intelligent appreciation

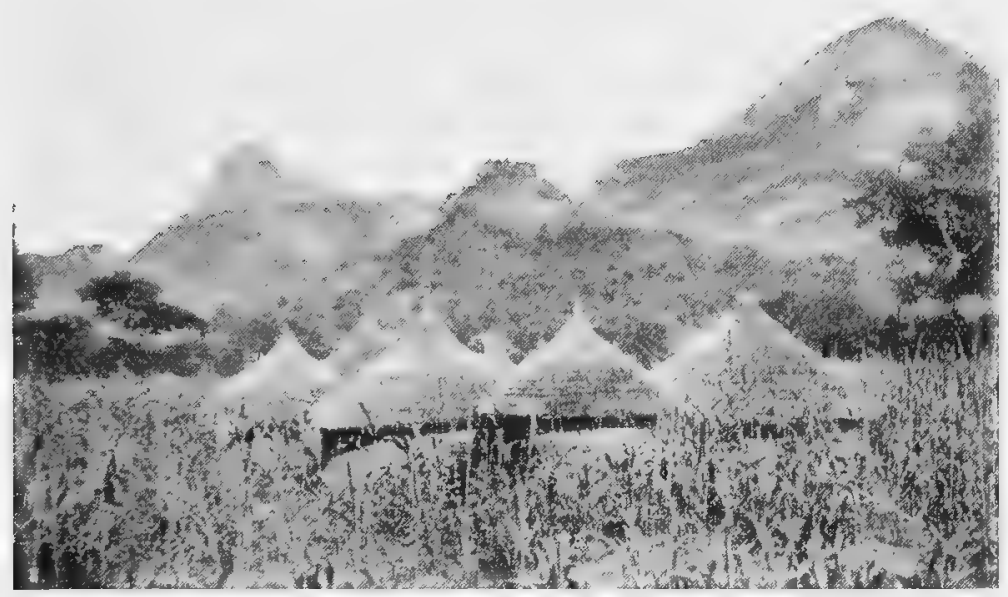

TTEIAGE IN THE SEAUA COCNTRY NEAR BAUCHI

of the harmonies. He was much impressed by the idea of my importance, when in answer to his question I told him that I was not receiving money from the King. He seemed to know a good deal about the movements of the Expedition, and I fancy he must have had an interview with my guide beforehand and have got up the details of our circumstances, after the approved fashion of royalty about to grant an audience. I daresay too, that not a few embroidered details had trickled through his servants from the "boys," who always constitute themselves one's trumpeters in a town; well knowing by experience that the bigger their master's reputation, the bigger the "chop" for themselves.

On the day following, the Emir came to my house in 
state to return my call. He rode at the head of about forty horsemen consisting of his guard and a mounted band with long trumpets and drums, and pipes called alligatas, of a sweet and low tone remarkably like bagpipes. The band played music that suggested a pæan of victory mingled with a dirge. It was very beautiful to hear, and haunted the memory with the deep sad wail of the pipes rising and falling on the roll of the drums and the blare of the long brass trumpets.

The Emir is supposed to be secretly inimical to British supremacy; which is very natural in him, seeing that he is by nature a fighter and ruler, who once had unlimited power and the lives of thousands of slaves in his hands, but now is shorn by us of his strength and obliged to rule side by side with weaker potentates, whom he despises and would have eaten up long ago, if it had not been for the muzzle we have put upon him.

There is a British garrison stationed about a mile from the town consisting of a company of the West African Frontier Force, with the officer commanding and two N.C.O.s. There is a Resident and also a doctor. This serves as a wholesome restraint upon the Emir, who otherwise is not interfered with more than is necessary, being allowed to administer justice himself and control his own prisons.

I stayed in Bauchi two days, during which I was busy labelling my birds, sending home my second box of skins from here by Sergeant Belverstone, R.F.A., who was returning on leave and very kindly offered to take it under his charge.

My next objective was Ashaka on the River Gongola, which had been chosen as a base for the survey column. 
It was also the farthest point to which the boats were to be taken before being carried by the main road, to be put

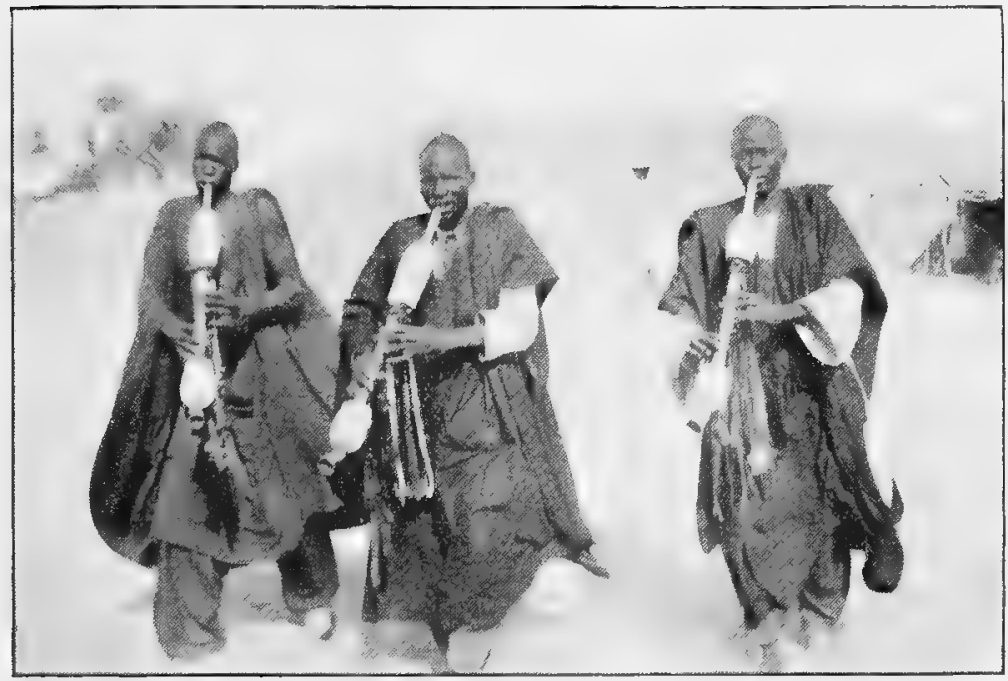

ALLIGATA PIPERS AT BAUCHI

together again at Gaidam for their journey down the Yo river.

The country round Bauchi underwent a change from that through which I had but recently passed, taking on a desert aspect with sparser bush, the characteristic acacia and gum-tree appearing in numbers for the first time. The fauna, too, began to have a sprinkling of Sudan forms and it was here I got my first crested-lark. I did not travel by the main road to Ashaka which goes north-east through Gombe, but struck away east by a little-known route through Goram, Kufa, and Ako to the River Gongola. Following the practice which I kept up through all my journeys, I paced and counted every yard of the road, tahing observations 
with a prismatic compass after every 500 yards traversed. My method was to turn down a finger at each hundredth yard and later on in the expedition, when I had thus fingered some hundreds of miles, the habit had become so deeply ingrained upon my mind that my boy, Quasso, told me I would often work my fingers and count for hours in my sleep.

I found that this part of the route on the Ordnance map had been very correctly done, which I cannot say for the mapping of most of the way I had come. In the earlier days of colonisation this was a branch of the work that was very imperfectly carried out; no doubt many of the mappers knew little of their work, while others were lazy and rode over the route, guessing at the average pace of their horses and writing down the first names that met their inquiries without corroboration. But the question of African names is always a most heartrending one to the careful mapper. When a chief dies, his village is called after his successor, and very often the latter, if he happen to be the first of a new succession, takes the people off and founds his village on a fresh site. Or in the case of rivers, there is a name for each part, according to the villages of the different tribes along their banks. Thus a new map of Africa, however carefully done, becomes obsolete in a year or two.

At Goram I was received very kindly by the king, who sent me a large "dash," consisting of several sheep and a cow. Having made him a present of cloth, large enough to show my appreciation of his generosity, I begged him to take back the cow. Sometimes, when one is not in need of such big quantities of food, or has not the means when doing 
forced marches of carrying live-stock, these large dashes are a doubtful blessing, and one invariably has to give a present of greater value in return. If one attempt to return a part, so as to regulate the size of one's own gift, one's reputation dwindles proportionately in the eyes of the king. I have known officials get out of the difficulty by selling the present the same day for what it will fetch in the market of the very town whose king is entertaining them. To my mind this is an act to be deplored as an infringement of those laws of hospitality, which the simpler native keeps so well. In saying this I do not wish to infer that individuals are so much to blame, but merely to express regret that the necessities of a businesslike administration should ever make it impossible to respect a fine old custom.

The King of Goram stood in great fear of the Emir of Bauchi, who had sacked his city four years before, killing his brother, who was then the king, and driving the present king to seek safety under British protection at Zunguru. He now rules by virtue of British support, but this does not free him altogether from the persecution of the Emir, who systematically sows disaffection among his subjects and saps their loyalty with threats. I found him sitting in lonely magnificence in company with a few faithful followers. He poured out his woes to me with a genuine appreciation of his pathetic circumstances, which succeeded in arousing my pity and I did the best I could for him. I told him to summon all his people, and when they were assembled, sitting facing I harangued them in the most impressive voice I could command. The simple mind of the Fulani, like that of all Eastern peoples, sucks up a shower of similes as the desert 
drinks the rain, so I spoke to them in somewhat the following terms: "People of Goram ! children of the big white king who can see over all countries with one eye, who calls you all by name; who is strong for all men; who gives you peace! Obey the chief he has set over you and know that, if you do not obey, the anger of the big white king will be louder than the thunder, and as sure as that sun which now sets, will rise again to-morrow, he will send his soldiers like locusts over the plain to eat up all your corn and destroy your city." As the interpreter, apparently with praiseworthy efforts to convey the spirit of my flowers of rhetoric, repeated each sentence after me, the people nodded their heads and clapped their hands. I then gave the king, at his request, a letter saying the same thing in very much briefer terms, for which he showed the most touching gratitude; a piece of paper covered with white man's writing is quite enough to invest its possessor with paramount power at any native palaver.

Two days' march from Goram brought us to Mamaidi, a fairly large Fulani town. Here the old king was not very friendly and omitted the customary "dash," so I told him to bring me two goats for which I paid him well. Next day, upon the march I noticed two consumptive-looking creatures being goaded along by my carriers, and when I asked their history and was told that they were the goats that had been sent in by the king, I knew that I had been "done," for I had picked out two particularly fine ones the day before. Therefore I sent back a messenger with a flag to the king, bidding him deliver up the goats I had chosen. Soon the messenger returned to say that the king refused an answer, 


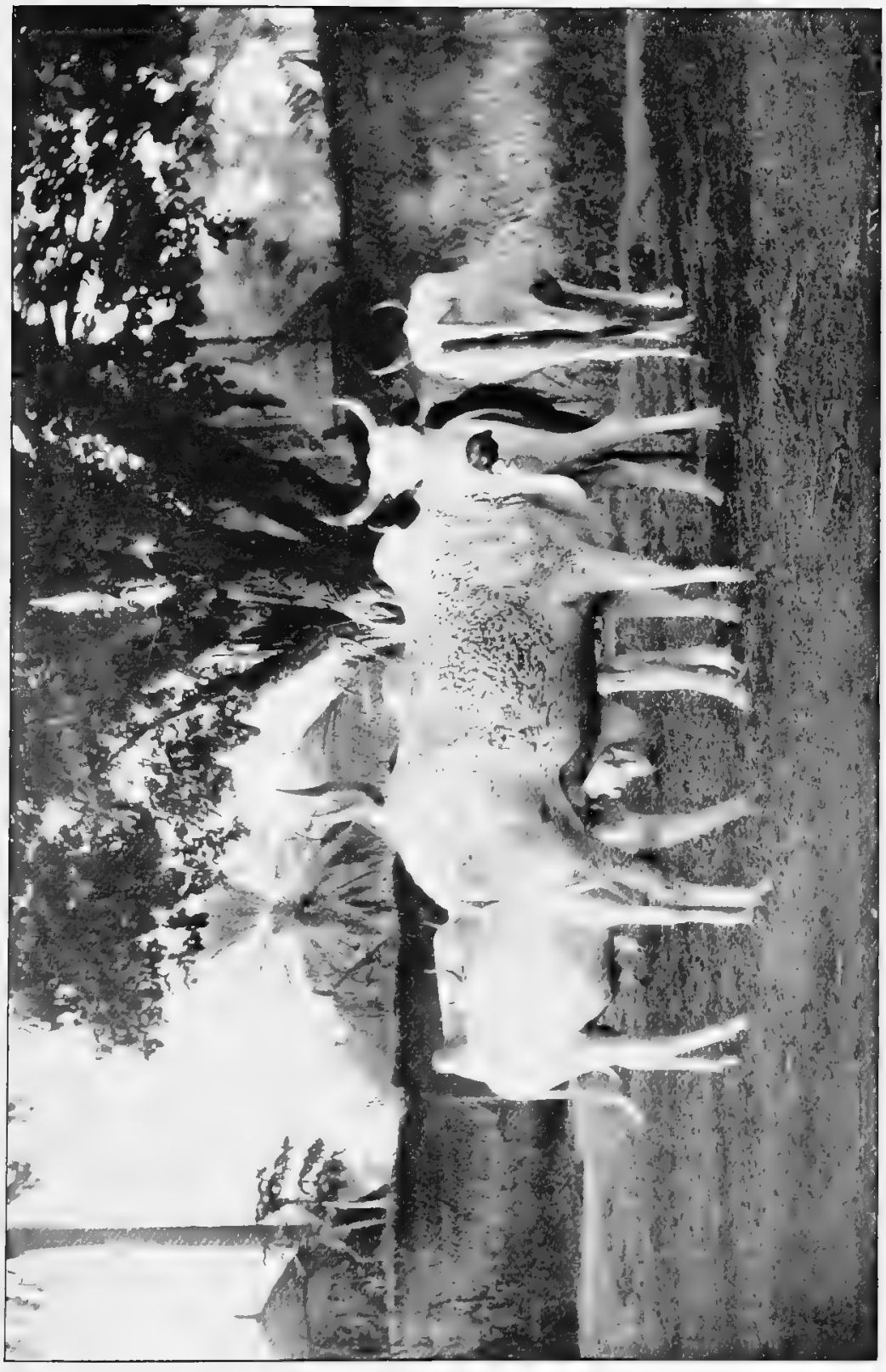

0
2
0
0
0
0
0
0
0
0 

saying that the flag was one he did not know. Such insolence was more than I could stomach and I immediately returned to Mamaidi with my column. On my arrival I found the town in a state of panic, and the people were already getting their belongings together in preparation for a hurried flight. The old king (to give him his due) was the only calm one of the lot, and was waiting in front of the palace to "face the music." I recounted to him his crime, and he made some excuses that were lamer than the goats. Whereupon I fined him fifteen goats, which I ordered him to send in to the Resident at Bauchi with a letter I had written detailing the case. I then left to take my road again, and I had not gone far out of the town, when I heard a great hubbub behind me, and looking back saw the old king mounted on an old horse, riding out of the city gates with half his people at his heels. Presently they overtook me, and as I strode along, the old fellow spurred on his rickety horse, jerking out entreaties to me to take back the letter. Meanwhile women and children pressed about me, wailing and screaming. We must have made a curious picture, and for a moment I almost realised the satisfaction of the Pied Piper. When the mournful procession had pressed along for a good two miles, I thought that the old king had taken as much exercise as was good for him, so I turned round suddenly and took the letter from him. Then, telling him that he owed his salvation to the love of his loyal people whose prayers I had heard, I tore the letter up and bade him go back in gratitude to rule his people with kindness. At this all the people shouted for joy and the women clung about my feet. Then a sound of laughter went rippling down the hill at the heels 
of the old king, who returned to Mamaidi a gladder and a wiser man.

It was here that the "boys" brought in for my inspection three wild looking men, who struck even them as being very curious. They wore no clothes on their lean bodies, except an ample loin cloth. They were of very low type and belonged to a tribe called Tingali, inhabiting a range of hills near Mamaidi where they lead a precarious existence, raising no crops and living for the most part on dogs. When hunger drives them, they come down to the villages of the plain and work for food.

At a place called Gaddam, which is about two days' march from Ashaka, I witnessed a Hausa wrestling-match for the first time. Towards sundown the whole of the population repaired to the market-place where a large ring was formed. On one side sat the king, surrounded by the whole of his court in their bright-coloured bernouses and turbans, and near to him, round the ring sat the big men with their friends. Every one had put on some gay covering or ornament for the occasion, and the women had tired their hair and painted their eyes with blue. All were in merry mood and the scene was pretty and gay. The bright colours of the crowd, blue and white predominating, with here and there a patch of red, mingled harmoniously in the soft light, and the mass was made more beautiful by a sprinkling of half-nude forms. There were groups of slaves with their masters' horses outside the ring by the palm-trees, and the arched heads and necks of two stock-still camels stood up like monstrous carved idols against the white walls of the palace. Beyond, the eastern sky was the purest sapphire blue, fast deepening to 
reveal the bright points of the stars. The wrestlers were naked, except for the short wrestling skirts of cloth gorgeously patched and ornamented with cowrie shells and tails of the chase. The match was fought to an accompaniment of drums, the beats increasing in volume as the wrestling became more exciting. Great yells of applause now and again went up from the sea of black heads, and the women, for whom the wrestlers were fighting, egged them on by a continuous clapping of hands.

Before the match, hands were shaken and umpires appointed. In every move the style was Græco-Roman. In all probability the mode has come through from Egypt after the Roman occupation, picked up by the travelling Hausa in the markets and bazaars. 


\section{CHAPTER XI}

JOURNEY CONTINUED FROM ASHAKA TO MAIFONI

DURING the evening a lot of native beer was drunk and the crowd became very lively, with noise of laughter and shouting that continued far into the night. The beer is not an unpleasant beverage, rather thick and sweet like malt extract and decidedly "heady." It is made by a very simple process; millet corn is boiled and stood out in the sun for four or five hours for several days; it then ferments and the liquid is strained off into large earthenware jars.

While I was at Gaddam, the King of Gombe, a large town two days distant to the north, sent his son with a handsome "dash" of four sheep and a good supply of "chop" for the "boys."

Our road now took a turn to the north, and the next night found us camping in the bush. Thence we went on to Tunga, a picturesque and populous Fulani town which stands out in my memory by reason of the numbers of storks' nests that were built on the fine baobab trees around. They were the only ones I saw upon our journey, and made a remarkable and pretty sight from my tent, which was under a fig-tree within the city walls. There were as many as twenty nests in one large tree, and I never grew tired of watching the mother birds sitting upon the nests, or standing up against the blue sky, that shone brighter for the contrast of their 
graceful white forms, as they waited patiently for the return of their mates, who travelled far to forage for the upkeep of

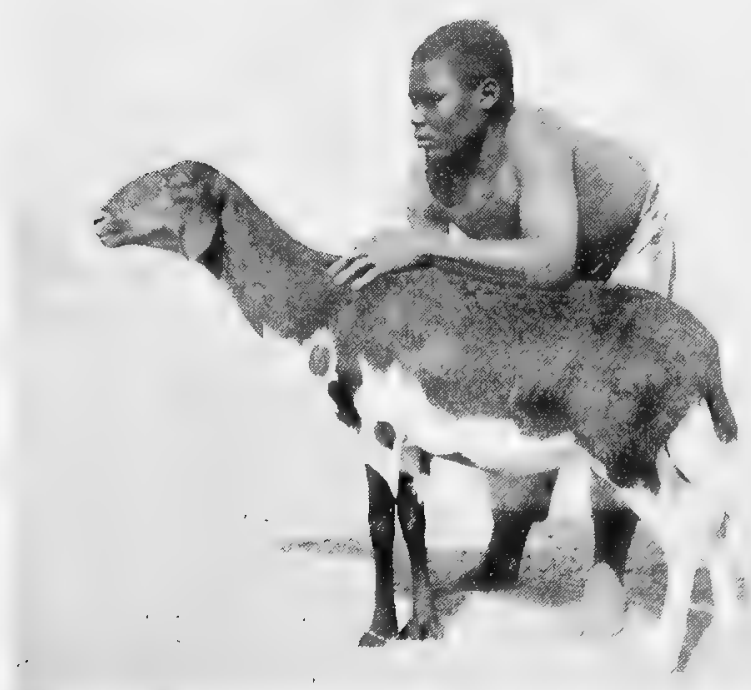

A BORNU SHEEP

their homes. Presently on the eastern horizon where the Gongola flows, a speck would appear growing larger and larger until one could discern the slow flapping wings; then soon sounded the swish of a great bird passing overhead, with long neck and legs outstretched to sail smoothly into the island haven in the blue, there to let down his feet like anchors and furl his wings. Then the stillness of the tree tops was cut by the scissor-like opening and shutting of the mother bird's bill, which received the delicious mouthful of the far-carried frog with a long rattling sound of gratefulness.

By noon on the next day we got as far as Bejoga, a village 
consisting of one street of wretched huts built by the refugees from the fallen city of Burmi, and about seven miles farther on, after journeying through open country sparsely dotted with trees, a rise in the ground brought us in sight of that ill-fated place. At a distance we could not see its desolation, and it appeared still to be a living city, with its strong walls and white houses of good architecture, above which rose the dark green tops of groups of date palms. But on approaching we saw the great cracks and holes in the walls and roofless houses; not a living being stirred in the streets, and all the open places were green with high-standing corn. This is the place where the Fulani power was broken once and for all by the British, in what was, perhaps, one of the most picturesque fights of modern times.

In March 1903, when a British force marched against Kano, they found the great iron gates of the city closed. But when these were blown open, the place offered no further resistance and order was restored and the market in full swing by the evening of the same day. Subsequently, after a slight opposition and some fighting, the city of Sokoto was subdued, but the Sultan Attahiru made his escape and fled southwards to the holy hill of Bima where he hoped to rally his followers, who were even then in considerable numbers. It was then that Captain Hamilton-Browne with Lieutenant Lawrence and a company of men made a successful night march and surprised the rebels at Gwoni at the foot of the hill, capturing their camp and inflicting heavy losses upon them. Thereupon the chief mallam, the fanatic ruler of Burmi, at whose hands a British force some few months before had suffered a reverse and been obliged to retreat to 
Bauchi, invited Attahiru to take refuge in his city and set up his standard, to which there flocked all the outlaws and malcontents of the country, and soon the place became a hot-bed of sedition. It therefore became necessary to suppress the seeds of rebellion, and for this purpose troops were drawn from all parts of the Protectorate.

The force was composed of about 500 men of the Northern Nigeria regiments; sixty mounted infantry under Major Barlow; one millimetre, one seven-pounder and two maxim guns under Captain Henvey; the whole under the command of Major Marsh. Meanwhile, the defences of Burmi had been strengthened, all the seven gates having been barricaded save that on the south side, where a second trench had been dug in addition to the one that ran all round the walls. At the foot of the latter, holes had been made to enable the defenders to escape within the town. The construction of double trenches revealed a degree of ingenuity unexpected in the natives, and leads one to believe that there must have been some ex-soldiers of our own or of the French forces in the service of the Sultan. Previous to the attack all the women and children had been sent away, and it is said that there were at least 10,000 men in the town. The majority of the defenders were armed with bows and many of the arrows were poisoned; some used throwing spears and others "dane" guns and rifles.

The attack was made at eleven o'clock on the morning of July 27. The troops formed square 300 yards from the town and the millimetre opened fire on the southern gate. It is a pity that this point had been chosen for the assault, as it was the only one at which an enfilading fire could be 
maintained from the trenches and walls. After a few rounds had been fired, making excellent practice, three half companies of infantry, supporting one another in column, delivered an assault upon the gate.

Within, the city seemed deserted, not the shadow of a living soul was seen and an ominous silence reigned. Then, as the troops neared the trenches and got within the angle of the walls, suddenly the air was benighted with clouds of arrows and shouts of "Allah! Allah!" arose upon a deafening alarum of drums. So tremendous was the surprise of the shock, that the leading column was forced to fall back on its supports, and the men refused to go on, for they said the place was full of "ju-ju." Thereupon Major Marsh, who had been directing the operations from the square, realising the critical position, went down at once to the fighting line to lead the assault; but he had no sooner come within the line of fire than he was struck in the thigh by a poisoned arrow and died within twenty minutes. Meanwhile, Captain Robinson, Chief Staff Officer, had sent Lieutenant Fox with a section to attack a hole in the wall about 150 yards to the left of the gate. The attack was successful and an entrance effected; when at the same moment Captain Lewis and Lieutenant Maud with a few picked men made a brilliant rush and captured the gate. Captain Lewis was twice wounded, but continued in action, and one of his native sergeants was shot through the heart. Once inside the walls, his men worked round on either side of the gate till they joined with those of Lieutenant Fox, and then there was no longer any doubt that the assault had been successful. The enemy fought with fanatical fury, defending themselves in the bukas 
(or round reed huts) that crowded the town by the southern gate. These were so tough that they resisted all attempts to fire them, and heavy losses resulted as a way was fought through them. Then for some reason unexplained the "retire" sounded, which the men obeyed reluctantly, for they had now warmed to their work. In the afternoon reinforcements came up and the assault was again delivered; this time to meet with a weakened resistance, and it was not long before the ground was regained. But fighting continued with stubborn opposition till sunset, when the enemy, refusing to surrender, made their final stand at the Masalachi (or House of Prayer), where Captain Henvey, who had worked all round the town with signal results, brought up his millimetre and fired case shot. The body of Attahiru was found among the dead by the gate. It is said that he was praying in the mosque with his mallams when the attack was made, and hearing that the "white man" had carried the gate, went down there with his personal followers to attempt to save defeat. Throughout the day hundreds of the enemy made their escape by the gates on the farther side of the town, and considerable execution was done by Major Barlow's mounted infantry, who pursued the fugitives as far as the River Gongola. Many more that had escaped in the assault, got away under cover of the darkness. At nightfall the troops withdrew and camped outside the walls. All round the gate where the assault was made, the arrows bristled the ground as thick as quills upon a porcupine. Half a mile to the south-west, on the road to Tunga, there stands a solitary fig-tree, where I was told the body of Major Marsh lies, but I could find no mark to show the place of his burial. 
The losses of the enemy were very heavy, and the Magagi of Keffi, the murderer of Captain Maloney, was among the killed. On our side there were over sixty killed and wounded, the latter including all the officers who took part in the assault.

Two miles from Burmi I arrived at Ashaka, a small walled and entrenched town of the same type. Before Burmi fell, it had been twice subjected to night attacks from the chief mallam, which were successfully repulsed by Major Barlow. There are pleasant palm-groves in the valley below, and I saw a number of very fine Bornu cattle, but the town wears a rather dirty and depressed appearance. I had hoped to be in time to join my companions here, but was told of their departure some weeks before by the old king who was very kind and communicative. However, I was glad to get some tidings of them and started next day to follow the boats.

Crossing the Gongola on October 9, I took the road that has been described in the chapter on Gosling's journey with the boats to Gaidam, and found myself at Gujba on the 11th. This place is historical as the battlefield where Faderellah, the son of Rabeh, was defeated and killed by the French on August 23, 1901. After twice defeating Garoba, the then Sultan of Dikwa, who now is Shehu of Bornu, Faderellah was chased by the French who surprised him at Agigin; but he succeeded in checking them and withdrew to Laraba, eventually establishing himself at Birguma, where Major McClintock visited him and arranged a treaty. However, it seems that after McClintock left, and before the treaty was ratified, Faderellah again attacked Dikwa, and the French 
once more pursued him. When on his way to Ibi to seek protection of the British, his brother Nyebe persuaded him to stop at Gujba; but when the French force, 230 strong,

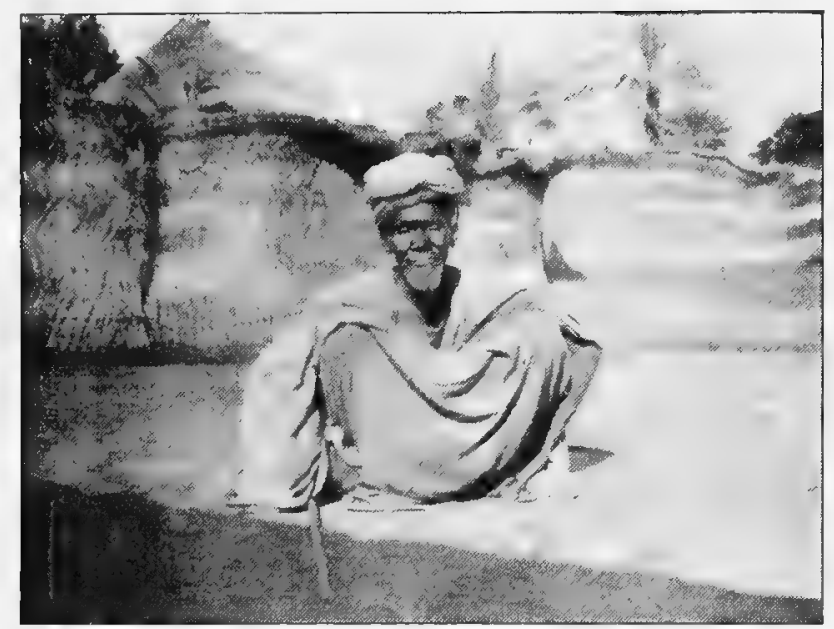

THE KING OF ASHAKA

made a brilliant forced march and came suddenly upon them, Nyebe entreated him to fly while there was still time. But Faderellah scorned to run away and went out with his 2500 soldiers to meet the French in battle. By his side, mounted on horseback and using a rifle, fought his heroic sister, Howa, who, when Faderellah was killed, exhorted Nyebe to continue the fight. But that chief was not so highcouraged and, kneeling in surrender, called on his men to throw down their arms. Faderellah's body was afterwards found by the French, buried in the bed of a stream near Mutwe. About 500 of his warriors were killed in this battle, while the French lost only eight killed and wounded.

Howa was wife of the son of the King of Sokoto, 
whom Rabeh once left in command at Dikwa while he was away fighting the French on the Togbau hills. His son-inlaw made plans to desert to the French, but when Faderellah,

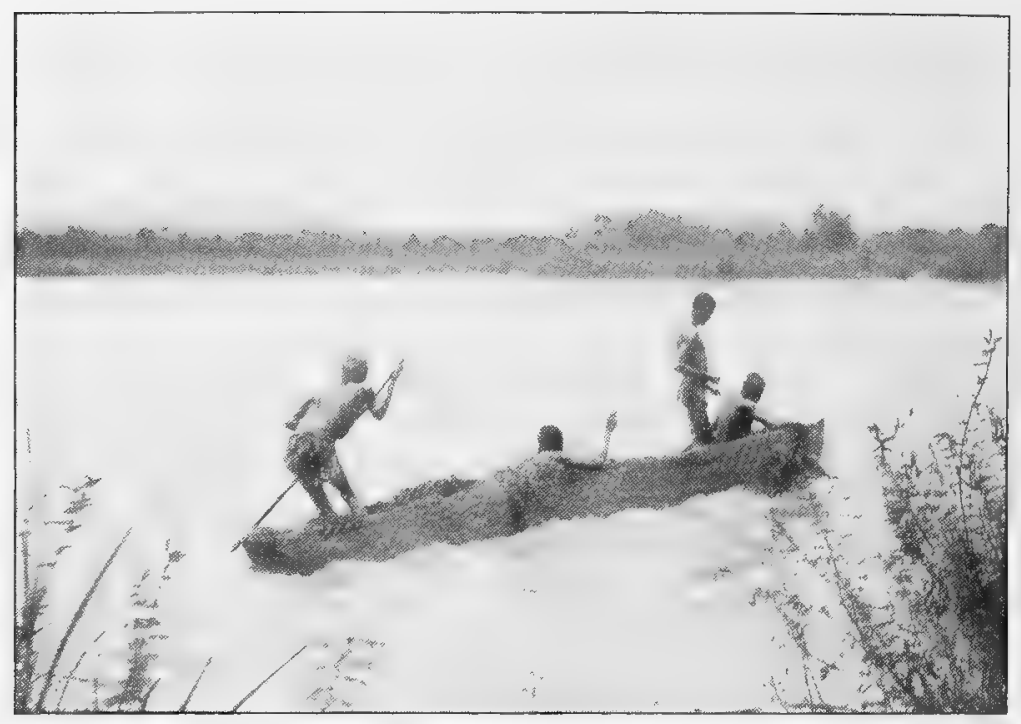

ON THE RIVER GONGOLA

then a youth, heard of this treachery, he called on the soldiers that were staunch to his father to follow him, and going outside the town met the Sokoto in battle and killed him. Afterwards Howa joined her brother in arms, and they fought together in many battles, and she commanded a party of horsemen in the great fight at Kusseri where Rabeh was killed. Howa is said to have been a fine shot with the rifle. She is now living with her attendant girls in a nice house at Fort Lamy as the pensioned prisoner of the French.

After staying a night at Gujba, I started on the 12th to cover the waterless distance of thirty-four miles to GabaiKalima. For this march we carried a supply of water in 


\section{JOURNEY FROM ASHAKA TO MAIFONI 231}

skins. In the afternoon we reached a waterhole about nine miles from Gujba, but found it dried up, except for a few puddles that the boys scratched out of the mud and eagerly drank up. Here we rested till sundown, when we took the

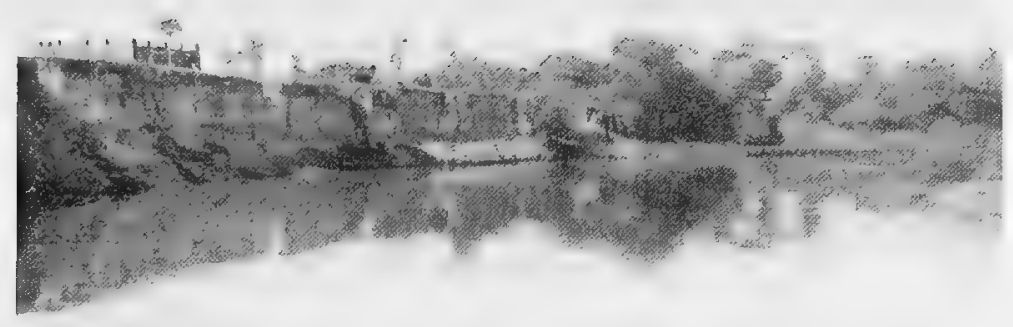

GAIDAM ON THE RIVER YO

road once again to complete the distance by a night march. After Gabai the country began to assume a desert appearance ; the bush became more sparse and dried up, and at intervals, growing more frequent as we proceeded, our footsteps were muffled by the drifts of sand. The land of rivers had been left far behind and we were now entering the land of wells -lonely spots in the sandy plain, where the women toiled at filling their water jars. We were on the edge of the Sudan that sprawls its tawny length right through from the east; and when after three days of weary, monotonous marching and swallowing the sand, our sore eyes beheld through the haze the white walls, the camels and palms of Gaidam, and strained 
farther to the blurred patches of the distant river line, we almost thought to see the white crescent tips of felucca sails moving along the horizon.

From Gaidam, where I stayed over a day to buy a few oxen to supplement my transport, I departed on October 18 , on my way to $\mathrm{Yo}$, taking much the same route as Gosling had a month earlier. At first I attempted to follow closely the right bank of the river in order to map its course, but belts of thick bush and swamp were continually barring my way, so I was forced to abandon my intention, and mapped the road instead. At this time there had been a sudden and unusual fall in the river, of which the Tubus took advantage at once to cross and raid, and all along the road there were complaints of cattle being stolen. About three days from $\mathrm{Y}_{\mathrm{O}}$, the road branches, and the right-hand path runs off into the bush for about four miles before it joins the main road again. Following my usual habit, I was half a mile or so in front of my " boys" when I took the path on my left along the river. After proceeding for about two miles, I came upon a party of twelve men armed with bows and spears, who sat under a tree by the roadside. As I could not speak to them I took no notice and passed on. A quarter of a mile farther, I passed another group, which set me wondering what their business might be, and then the idea of an ambush crossed my mind. Still, I could do nothing but go straight ahead, when suddenly I became aware of the points of spears approaching above the bush that masked the windings of the path in front, and presently a band of horsemen came in view. I must say that I passed a few uncomfortable moments, for the idea of Tubus was in the air and I was 
unarmed. However, my fears were set at rest when the chief came forward and saluted me. He proved to be the headman of the Kachella of $\mathrm{Y}_{0}$, with about fifty horse and a party of arrowmen. He said that he was hunting Tubus and had sent out scouts into the bush; which explained the parties that I had met. He asked me where my carriers were, saying that it was dangerous to travel alone.

I now began to have fears for my "boys," who ought to have come up with me by this time, for it had not occurred to me that they might have taken the other road. So, riding a horse which the chief lent me and accompanied by him and his horsemen, I at once returned to look for them. After an anxious time of doubt we at length came upon their tracks along the alternate path, but did not overtake them before getting into the town of Duci. On the road his scouts came in to us, bringing a Tubu family which they had captured in the bush. It was a very picturesque group, and a most gentle surprise after the fierce people that the recent alarms had suggested to the imagination. For the family party consisted of a spare, shaggy man, armed simply with a spear, and leading a brown, rough-haired camel, and clinging to the man his wife, naked except for a scant skin, and with wild frightened eyes piercing the shade beneath her fringe of black twisted hair. The camel presented a most extraordinary sight. It was like a living gipsy caravan, piled up with all the household furniture of tent and cooking-pots, waterskin and bag of meal; and hung all over with bundles of skins, which were their articles of trade. And out of the lump of jumbled goods peered the scared faces of three skinny little children. The Kachella's headman wanted to send 
them in to the Resident at Gaidam, but I had fears that this might mean they would be relieved by their guard of a good many of their belongings upon the road. Besides, they had all the appearance of being the innocent traders that they assured us they were, so I listened to the silent supplications of the woman who knelt at my feet with upstretched arms, and let them go, much to the disgust of the Kachella's headman.

At Pogwa I was very glad to see José once more. He had heard news of my approach through the Kachella and so came out from Yo to meet me. And I was looking forward to seeing Gosling when I should get into the town. So, when in answer to my inquiries José told me the latter had left only two days before, I was much surprised, but my surprise quickly turned to disappointment when I heard that he had gone in response to Talbot's request for assistance because my brother was ill. I determined therefore to follow as soon as I could conveniently do so, but at that time I did not realise that there was much need for alarm, or that my brother was suffering from anything more serious than the inevitable fever.

Two miles outside Yo the Kachella, at the head of his horsemen, met and saluted me. Then we drew side by side and, out-distancing the body, galloped into the town. Next day I held an inspection of the escort of the Expedition under the quartermaster, Dan Galadima, whom I presented with the medal he had won in the Kano campaign, that I had been entrusted with at Lokoja to give to him. He was a proud man that day as he received his honour in sight of the Kachella's soldiers and all the inhabitants of the town. 


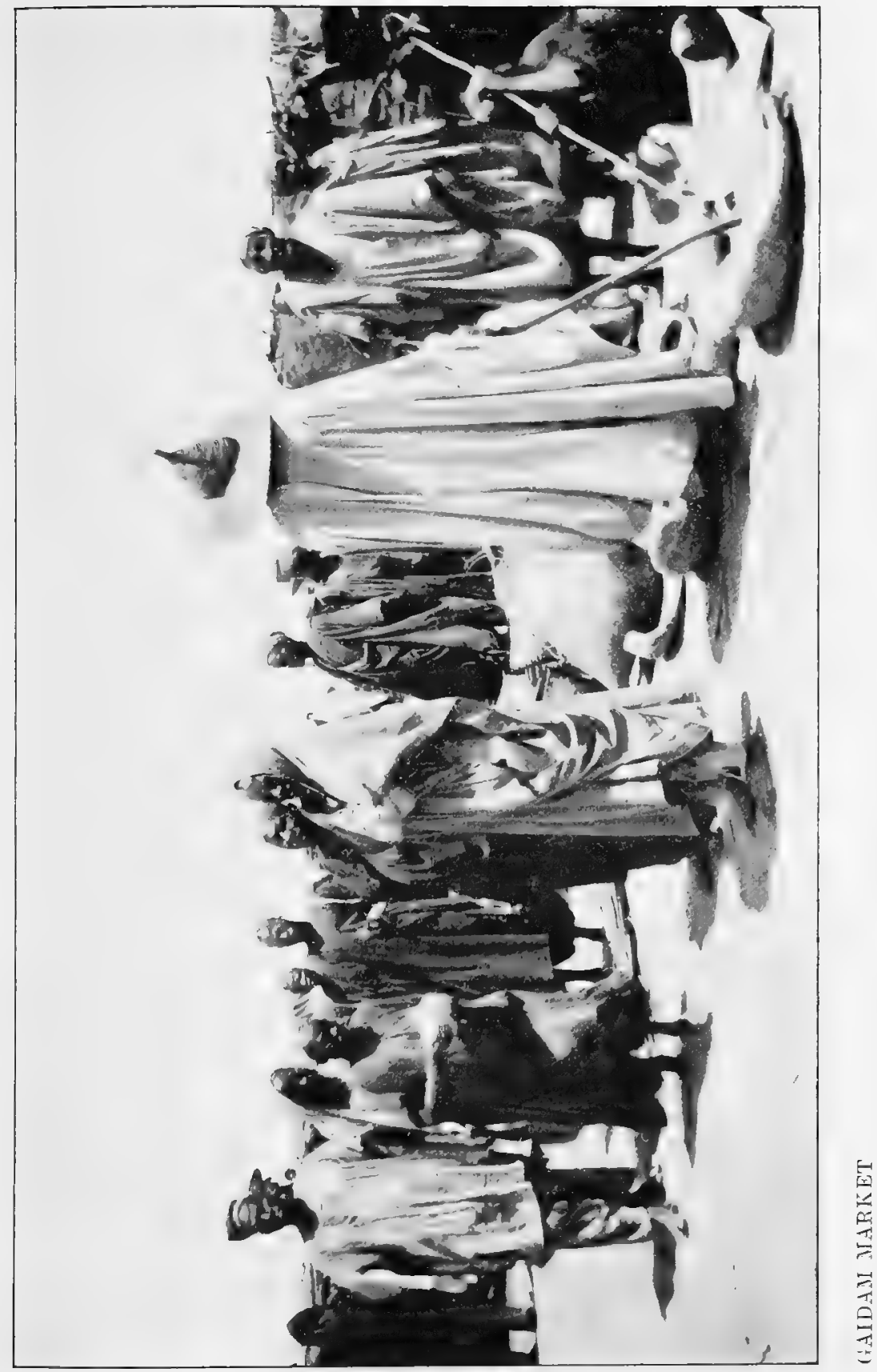



And when in the after days and rougher times of the Expedition, all his possessions had fallen away from him, and he marched into Khartoum in nothing more than a ragged shirt, his medal still shone bright upon his breast. In the

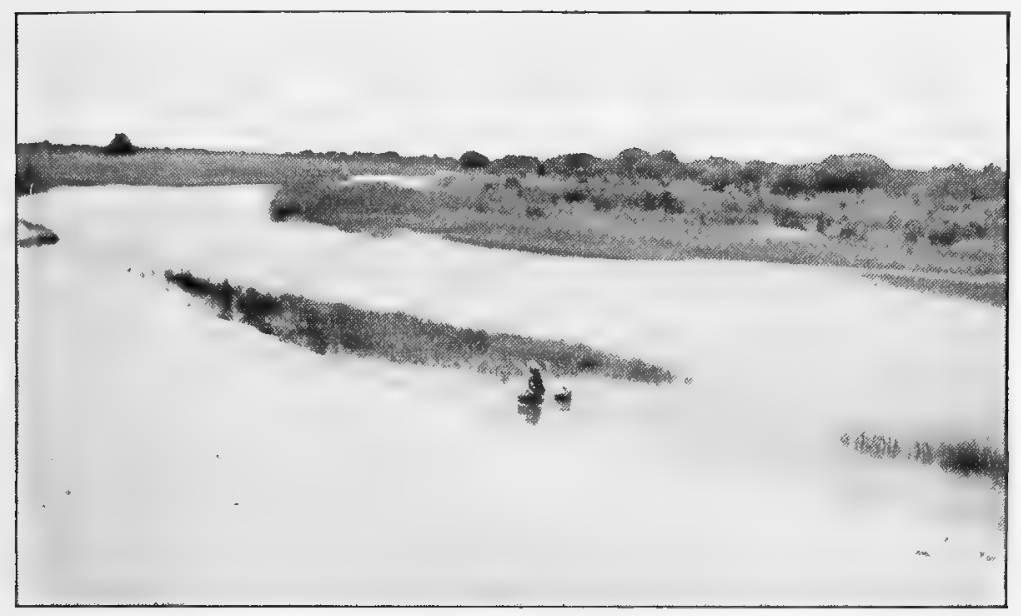

THE RIVER NEAR YO

evening we gave the Kachella a pyrotechnic display, consisting of half a dozen rockets, some of the very few that were saved from the sinking of the canoe on the Gongola. They were of enormous power and splendid beauty, each coloured ball long after the great fountain burst breaking again with loud reports in vari-coloured jets of their own. They did not fail in their purpose of creating a sensation and were great feathers in our caps. They were even startling in their effect, for all the horses in Yo stampeded and the people of Bulturi, thirty miles away, made preparation for flight across the river. How we wished for a few more of them later on in the Expedition, when we were among peoples that were still more impressionable! 
I left $Y_{0}$ on the 26th and stayed for the night at Arrege. The town is in ruins, and its few inhabitants live in huts among the broken houses. Outside in the sand bleached bones and skulls are scattered, that mark the bloody track made by Rabeh's army. All that night my sleep was continually broken by the mournful howls of dogs from every quarter round, that seemed to be echoing the melancholy of the place.

In the morning I went down to have my first look at the Lake, mentally striding the three or four miles on the tip-toe of expectation, for I was about to see the dream of many days embodied at my feet. For the first two miles the path led through thick bushes and gum-trees, and then we came out on to an open plain, a mile wide, and there beyond lay the broad, silvery expanse of Lake Chad, merging so gently . into land and sky as it lay quivering in the haze, that it seemed like a soft reflected light flashed from the mirror of the sky. But my contemplation of the Lake was abruptly disturbed by the sound of shouts and clashes, and on looking in the direction whence they came, I could see a crowd of men down by the water's edge busily engaged in battle. Taking a better sight with my glasses, a most lively scene presented itself. There were twenty to thirty men, rushing wildly about and engaging in hand to hand combats with spears and shields. The spears were being thrown in all directions, but so deftly did the fighters use their shields, that none were killed in the battle and only a few got wounds. But then the battle was never fought to a finish, for after I had been watching it for a few minutes with feelings of excitement akin to those of the crowd at a Cup Tie match, 
a shot rang out in the bush behind. Instantly the heroes scattered, the one side disappearing into the reeds and scrub, while the other dashed straight into the water and waded and waded till they faded away in the distance, still wading. Thus was my first impression of the curious shallowness of the Lake realised in a rather strange manner. To go back in my story for a moment: before we had emerged from the belt of bush, we had seen a herd of kob away on the plains to the right, so José turned off the path to stalk them, and it was the report of his shot that had so effectively cleared the battlefield. It appeared that the fight was being waged between the Kanembu herdsmen of the land and the Buduma because the latter had stolen some cows and carried them off to their islands. If I may be forgiven for tampering with the classics of the Nursery, I think the alteration of a few words in a famous poem tells the story in the simplest language.

Kanembu and Buduma

Agreed to have a battle, For Kanembu said Buduma

Had spoiled him of his cattle.

Just then a kob by us did go

And José fired his barrel,

Which frightened both the heroes so

They quite forgot their quarrel.

I now followed the shore line all the way to Kaddai, counting every step and taking observations for a map. Once we caught sight of what appeared to be a white man's boat on the horizon, and my spirits fell at the idea that a French gunboat had forestalled my explorations. But happily it proved to be a Buduma canoe, with its reed-built 
sides shining brightly in the sun that gave it the more imposing appearance. A little farther on a whole fleet of them came into view. They were evidently busy at their fishdrying, for smoke curled up from fires in their prows, while great strips of fish were drying on wooden frame-works fixed round the gunwales. On catching sight of us they scattered and disappeared. At Kaddai the Budumas of the fish market were very friendly and brought us presents of fish. They did not seem at all averse to the idea of seeing more of us later on, and we left early next morning with friendly handshakes all round. By four o'clock, before we got into Bré, the carriers were suffering much from thirst, so I sent José on to fill a couple of water skins and bring them back to us while we rested by the wayside. He returned in a few hours with a mounted messenger from the Shehu bearing a letter from Gosling with the news that my brother was now dangerously ill. Therefore I determined to push on to Maifoni as fast as possible, and started at once for Kukawa with José and Lowi, leaving the carriers to follow with the transport next day.

The way seemed interminable for we were very weary, but at length on gaining the rising ground about three miles from the town, our spirits revived as our eyes beheld the warm glow of the fires of Kukawa. We got in at midnight, and I at once went to the Shehu's palace and sent in a most urgent message to ask if I could be given fresh horses. Whereupon, the Shehu himself came out and we met informally in the dark. While we were waiting to hear if horses could be got, he proffered me sweets from a bag he was carrying. I found them rather nasty but I could not refuse, as he was so pressing. 
After some time his messenger came back to say that the horses would not be ready before morning, so, bidding goodbye to the Shehu, I spent the remaining hours of the night resting in a straw shed outside the palace, which is used as a guard house. The Shehu offered me the shelter of one of his houses, but I felt too weary and anxious to move from where I was. In the morning we made an early start, but when about two miles on the road, I was seized suddenly with a most violent colic (for which I am inclined to blame the Shehu's candy), so I was obliged to return to Kukawa and lie down for a while. The carriers had in the meantime come in, and I was able to get at my medicines and best friend of all, my hot-water bottle.

By four in the afternoon I was better and on the road again, and we reached Mongonnu, a distance of fifteen miles, in the evening. As it was growing dusk, a large leopard bounded across the road just in front of my horse and José fired his revolver at it as it made off in the bush.

The King of Mongonnu, a big, fat, homely man, received us with much friendliness and a big fire in a large round hut, where Lowi attended to my needs with a cup of hot bovril. Here we found remounts waiting for us by order of the Shehu, and after a few hours' rest were in the saddle again. We passed the town of Wulo in the morning, but pressed on without stopping to change horses, as it was early. However, as the day wore on, our horses showed signs of knocking up, so we left the road at the next Shua village which was a little way off in the bush, for the purpose of commandeering fresh ones. On our approach we saw plenty, for the Shua are great horse-breeders, but when we made our wants known 
to the chief, he assured us that his people had none. However, when we hinted that it might be serious for him if this state of things were to continue any longer, the horses were forthcoming. That night we arrived at a village called Marsu where we did not stop, but continued riding through the night till well on into the next day. Then we met some of Gosling's carriers who had been paid off and were returning to Kukawa. They told us that my brother was better; so, being very tired, we turned off to a small village, called Chessangala, and rested for the night. Next day, having changed horses we rode into Maifoni at noon. 


\section{CHAPTER XII}

\section{MAIFONI}

Matfont stands on a sandy hill in one of the most fertile districts of Bornu. From the crest of the rise a beautiful view of corn lands is to be seen. The people of the country

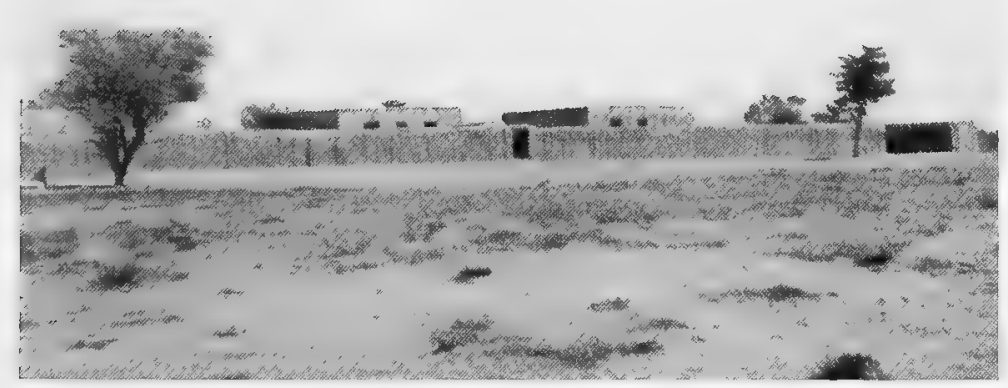

FORT MAIFONI

are prosperous, and there are flourishing markets where traders come from far to buy the renowned cattle and sheep of the country. Here, in the time of Barth (1851) there was a large town that more than covered the hill, with a population of 10,000 , engaged for the most part in farming; there were also workers in domestic industries and large dyeing pits stood by a market-place that contained 200 stalls. Now not a wall remains to mark the site of the city of that 
day, and the only traces of former habitations are the broken shards that are turned up from the side of the hill, and the swarms of white ants that are never to be found in great numbers on ground trodden by man. In its place, a British fort crowns the hill in grand solitude, except for a small village of native huts some little distance down the northern slope, and a few market stalls where trade is carried on with the soldiers' wives.

The fort is an imposing mud structure, about 50 yards square and surrounded by a 6 -ft. wall and ditch. Within, there are two square blocks of houses and a guard-house. The garrison consists of a company of the West African Frontier Force, which was at this time under the command of Lieutenant Farmer, a smart soldier and good man. It was a great blow to me when, on my return to England, I heard the sad news of this officer's death, for I was cherishing the hope of being able to shake him by the hand once again and thank him for his strong help to us all in the dark days of my brother's illness.

The soldiers live with their wives in huts half a mile down the hill to the south. In the plain on the east there runs a beautiful little komadugu, or stream, of excellent water. In the dry season when it ceases to flow, wells are dug in the bed where good water is always found. With this great advantage so near, and taking into account its fine situation which commands the whole country for miles around, Fort Maifoni is ideally placed from the military as well as sanitary point of view. The selection of the site was made by General Morland in the year 1901, and speaks well for that officer's sagacity. The fort was built by Lieutenant Ross out of the 


\section{MAIFONI}

profits he made on cloth in the native markets, so that the Government has this fine piece of work as a free gift.

A most interesting and remarkable feature of Maifoni is

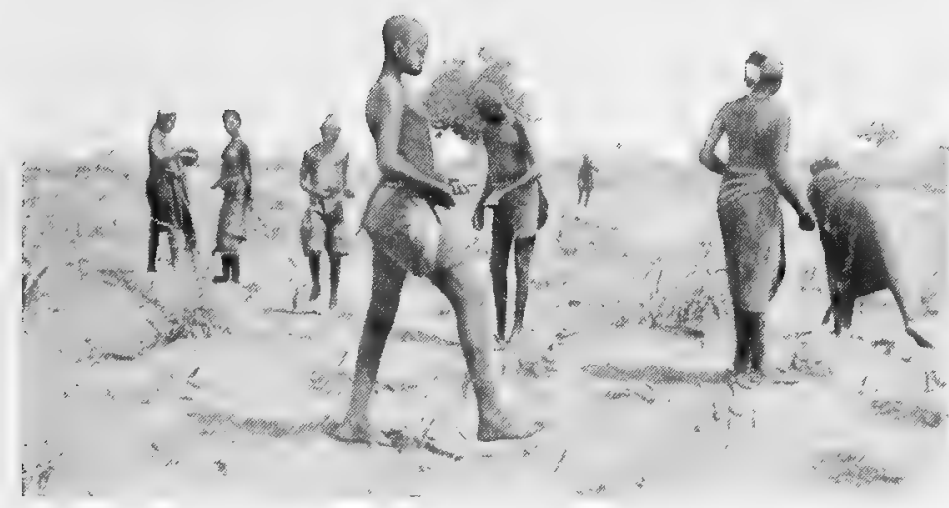

FREED SLAVES WORKING ON THE FARM

the home for freed slaves, originated on the idea of the Hon. 0 . Howard, and organised and carried on by Dr. Parsons as a labour of love entirely independent of outside help. It was started in February 1904, with the object of providing a temporary abode for women and children, who have been liberated by the British Government from slave caravans coming chiefly from Adamawa and other places upon the confines of Bornu. The boys are trained as cadets, and are drilled each day and taught to conform to the useful discipline of a military training. To give an example of the keenness of their spirit -the head boy, aged twelve, once in the absence of Dr. 
Parsons, acted as Commandant and had all his company out on parade each morning. During the wet season the boys work on their farms and at other times they attend classes in various local crafts, and those showing special aptitude are apprenticed to leather-workers, mat-makers, tailors, smiths, \&c. The women and girls occupy most of their time with the preparation of the food and other household duties, but they also work on the farms and gardens, and some devote their energies to the manufacture of pottery, nursing the sick, and making garments. The regular duties embrace strict cleanliness and attendance at a nightly roll-call. Absolute obedience to those in authority is incumbent on all, and all are taught to work together for the common good. The products of the farms go some way towards supplying their needs, while the flocks and herds, poultry-farm and market gardens are a source of revenue to the home. The staff, under Dr. Parsons, consists of a matron and three assistants. The matron is a Hausa woman of very exceptional qualities, and is one of the most loyal and trustworthy of native officials in the country. The three assistant matrons, who also receive pay, are themselves freed slave women who have risen to these positions of trust and responsibility.

The children amuse themselves with football, swimming, dancing, and singing. They dance most creditably several English dances to the accompaniment of a gramophone. There is an annual gymkhana meeting at which they can all show the proficiency they have attained in these various accomplishments. Any woman may leave the home if she wishes, but most remain till they can be suitably married. Every year several children are restored to the parents 


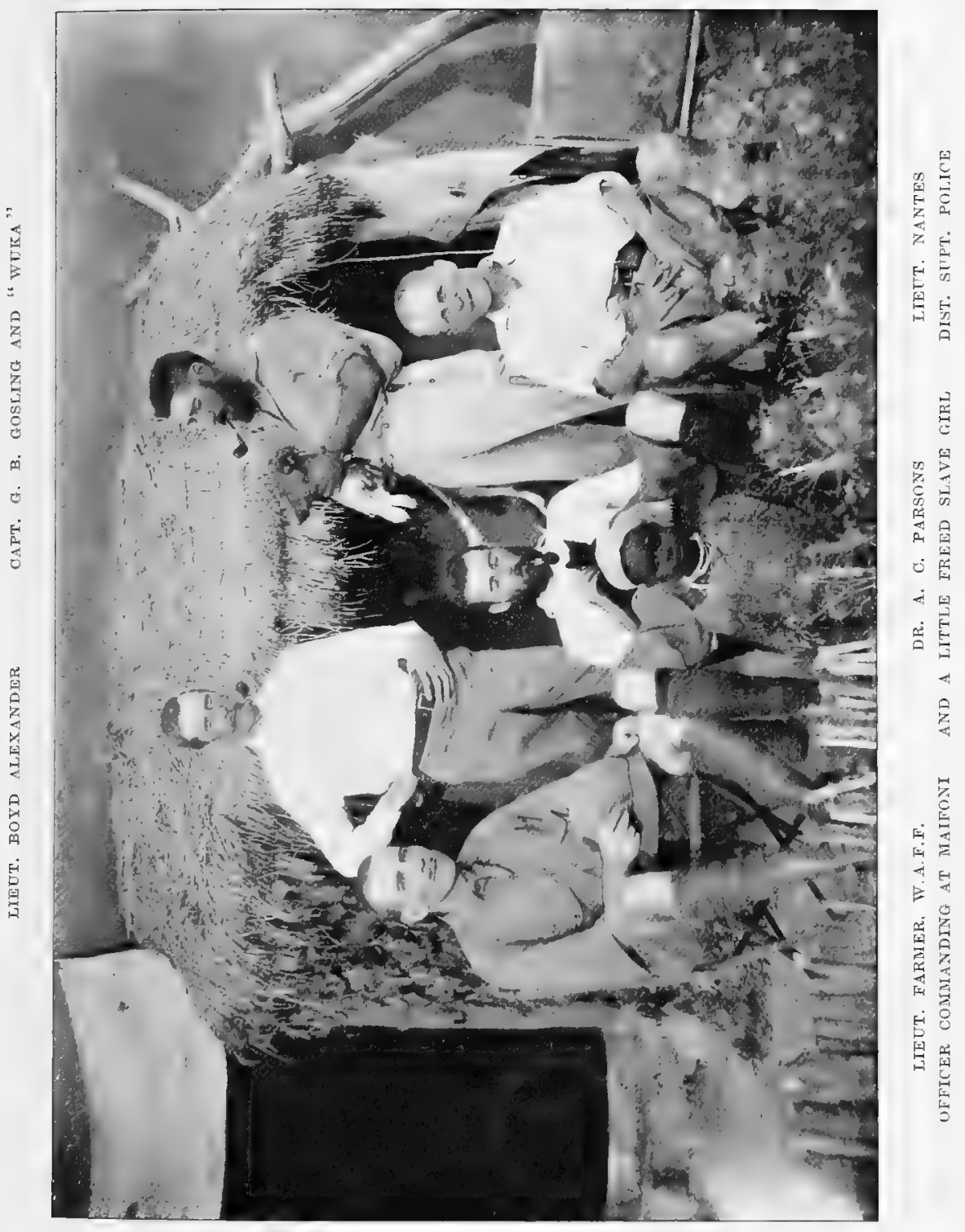


who have lost them, and employment is found for all boys who leave the home as time-expired inmates at thirteen years of age.

It was on November 4 that I arrived at Maifoni. Thus all the members of the Expedition were once more together again after a separation of five months. Under happier circumstances this would have been an occasion of great rejoicing, but, alas! we had obeyed a summons too sad to admit of our showing much joy in the meeting. On my arrival I found that my brother had made a very decided rally, and I think that the joy of having us all about him once more helped a great deal to maintain the improvement. But remembering his robust appearance when I saw him start with the Survey Party from Ibi, I could not fail to be very much shocked by the traces of the pain he had suffered during the long weeks of his illness. I now learned the details from Talbot, whose notes I will give as they will bring the account up to the time of my arrival.

"On October 3, while working near Dallwa, it came on to rain hard, and for the first time under such circumstances Claud said he thought he would go back and change, and to my concern he did not come out again that day, which showed he must be feeling very unwell. Next morning a letter arrived from two officials on their way from Maifoni to Yola, asking him to go out and meet them on business connected with the Expedition. This he characteristically insisted on doing, though he really was not fit to get on his horse. He would neither let me go for him nor send an answer regretting his inability to meet them. On his return he was looking wretchedly ill and had to go to bed at once, as he could not 
stand. However, he declared that there was nothing really the matter with him, and that it was only a slight fever which would soon pass off. Next day he seemed to be a little better and we moved on a mile or two to $\mathrm{K}$ woiangia, where he again had to go to bed.

"On October 6 I left him, as he would not hear of my stopping to look after him, and said that he hoped to rejoin me soon. But next day, there came a message to say he was worse and to ask me to go to him at once. He complained of severe pains, but we neither of us could think what was the matter, as it certainly was not an ordinary attack of malaria. He thought that it might be due to some native honey which had been brought in and of which he had eaten a good deal of wax.

"As he grew no better, I sent in to Fort Maifoni, which was only about four hours' distant, and asked the doctor to come out and see him. A message came back to say that the latter had gone off with most of the troops and some Kanuri on an expedition against that section of the Marragi, who lived on the Maifoni-Yola road. I, therefore, sent on after them to ask the doctor to return as soon as possible, and later on, as Claud grew worse, sent another messenger with a still more urgent request. The pain in the meantime had grown so terrible that I sent in to Fort Maifoni for an instrument by which I thought it possible to relieve him. Boiling baths had only a slight effect, and just before the instruments arrived, the agony had grown so intolerable that he told me it would be impossible to last out more than an hour or two longer. About midnight, Farmer galloped in through the darkness. Immediately on receipt of my letter, he had seized 
all the instruments he could find, on the chance that the one I asked for was among them, and had come at a break-neck pace along the narrow native path. To my great joy, I found

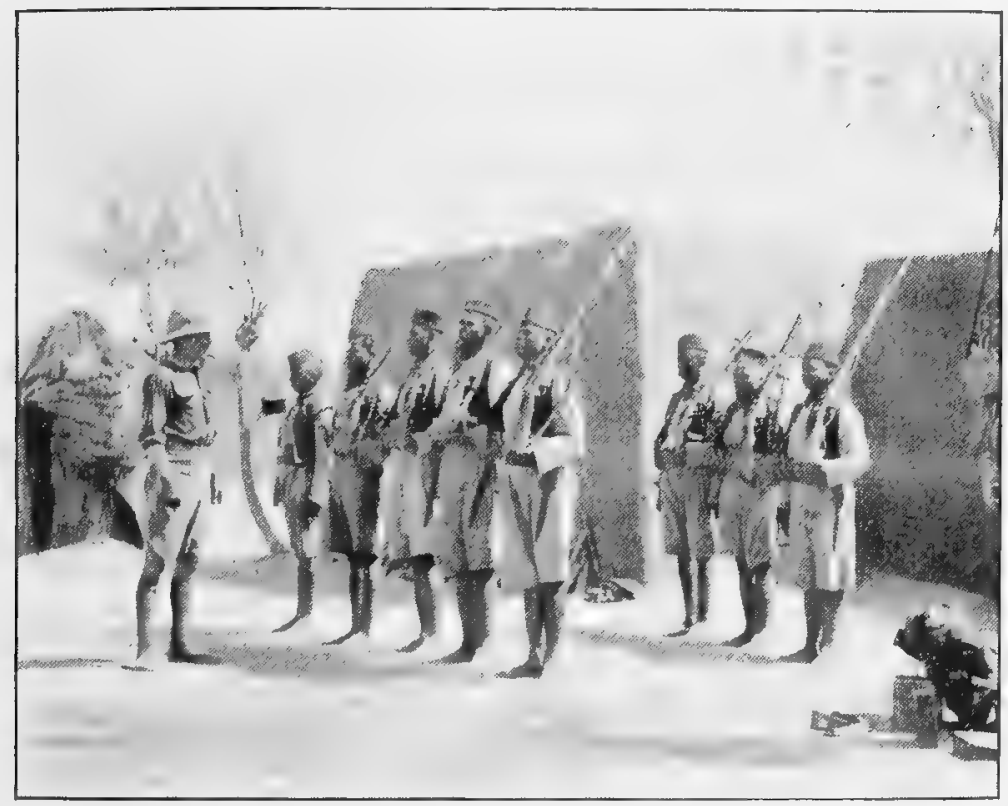

LIEUTENANT FARMER INSPECTING THE GUARD

what I wanted among those he brought, and after performing a slight operation, had the inexpressible satisfaction of seeing that Claud was greatly relieved. He dropped off into a quiet sleep and next day was much better.

"On the afternoon of the 12th, Dr. Parsons came up and took charge of him. He was progressing so well that on the 1.th he was carried in to Fort Maifoni and even walked from the fort gate to the house which had been prepared for him.

"Meanwhile, much relieved on his account, I went on with the work, but two days later the remaining theodolite 
had a fall which rather bont the vertical circle. I took it to pieces, however, and mended it so that it was quite reliable for the purpose of sun azimuths. From here check latitudes were obtained by means of the sextant and differences of height carried on by two boiling-point thermometers and two aneroids. On October 20, I reached Maifoni and was glad to find that Claud seemed well on the way to a complete recovery. So I continued the survey along the road to Kukawa, and was in camp at a place about fifteen miles from Maifoni, when on October 27, a messenger arrived with a letter from Parsons asking me to come back at once, as his patient had had a relapse. I sent immediately to Gosling, whom I knew to be somewhere near Lake Chad, to give him the news, and then I, of course, galloped back that night to Maifoni, on a splendid horse of which Claud had made me a present a few days before. Fortunately the moon rose after a time and the ride did not take long. On my arrival the sentry thought that I was a suspicious character, as I did not want to speak loudly in answer to his challenge for fear of disturbing Claud in case he had fallen asleep. He almost fired at me, but at length recognised me and let me in. Claud seemed better, so not to rouse him I waited till next morning before visiting him, but after this took up my quarters in his room."

A few days later, as has been related in a former chapter, Gosling, who had set out immediately on receipt of Talbot's letter at Yo, arrived at Maifoni, and I came in two days after him.

Though painfully worn, I found my brother wonderfully cheerful and alert in mind. He showed great interest in all our news, talking a lot himself and always returning to the 


\section{MAIFONI}

subject of the great kindness of the friends about him, which he described as being beyond words. His thoughts, too, often returned to the people at home, and, knowing that he

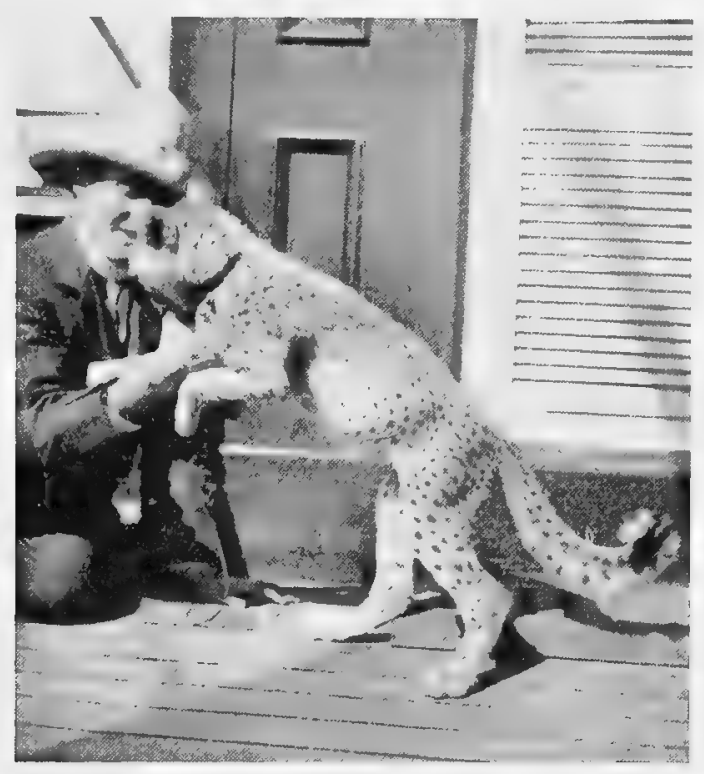

TALBOT WITH DAMESSA RETURNING TO ENGLAND

could not hide from them the fact of his illness, he wrote long cheery letters making light of it to allay their anxiety. On October 15 he wrote to break the news of his illness :

"MY DEAR Mother,-I really must not let the quick extra mail go without a line in return for all I have got the last few days. The posts have been dropping in in rapid succession till we are now no longer in arrears. Your letters have given me the greatest enjoyment because $I$ have been greatly bored for the last week, hardly been able to move off my back for a sort of chronic 'colly wobbles.' The long 
journey I took just after I wrote last . . . did me no good as I had intended keeping my tent that day. And that was when I fell sick. I am going on first rate with everything I want-which is not much. The doctor, a real good man, cannot understand how I have kept so fat and strong on lime fruit juice and water. So I have given him some lectures on fasting ! I hope to be about again very soon now, and then I shall feel I am starting with a clean sheet and bottled-up energy. . . Y Your tales of 'Lassie' (his dog) are always delightful. I wonder if she will know me when I get home. The cutting through the bush has reached here. Talbot is finishing some measurement work and angles now on the way. By-the-bye, he is an ideal nurse, doing everything with wonderful quickness. This delay is a terrible nuisance. .. I heard from Bee the other day, saying that he was coming along and was very fit. Gosling has reached Yo and I expect the first English boat will have been on Lake Chad by now."

And on November 2 he wrote :

"Mr DEAR Mother,-The last time I wrote I thought I was doing so in rather an express way (vîa Yola) but the runner has come back saying that the Pagans on the Yola road 'chopped' his boy and forced him to return. However, he has started off again after a short delay with a few soldiers as escort. It seems extraordinary, doesn't it, an important road like the Kukawa-Yola road being still unsafe? I believe the Pagans concerned are 'booked' for the dry season, the last straw being that $\mathrm{H}$ - had his whisky attacked a short time ago ! . . I shall not be able to get away just yet, 


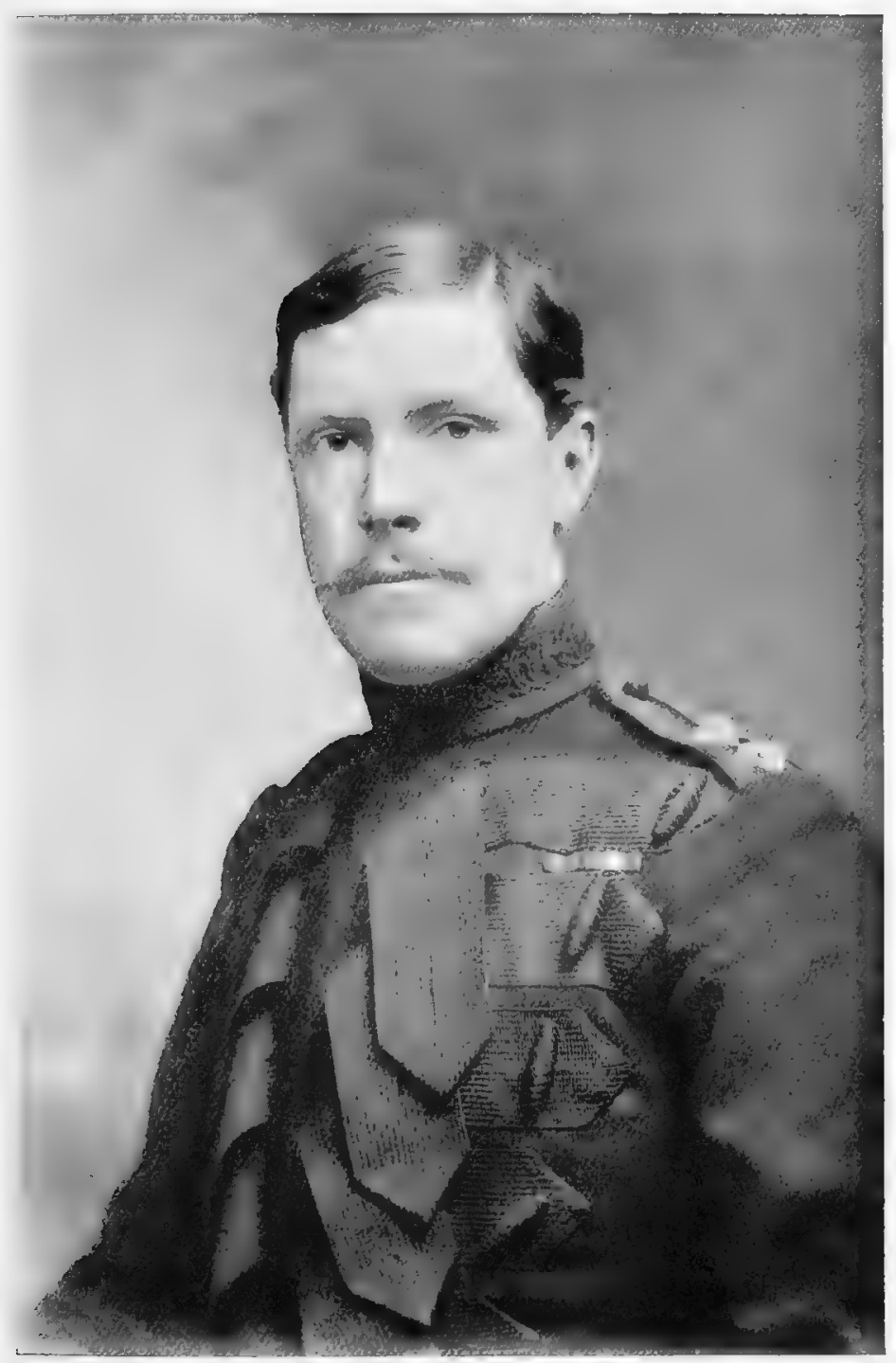

CAPTAIN CLAUD ALEXANDER

SCOTS GUARDS 

although I am practically recovered from the gastric attack I mentioned in my last letter. All I've got to do now is to feed up. . . . The doctor here, an excellent man, encourages me to tipple a pint of champagne most nights. This I do i the small hours by the time it has got icy cold. . . . I am in a splendid mud-walled and roofed house, cool as a cucumber. We have three small leopard cubs and a gazelle always playing about. The former are about the size of cats and are the quaintest little things imaginable. . . ."

Talbot got the cubs at Kwoiangia, from a man who had taken them from a lair in the absence of their mother. They were only a few days old and he brought them up by dipping his finger in warm goat's milk and then letting them suck it. Two of them died afterwards from the fatigue of constant trekking, but the biggest and strongest, named Damessa grew into a splendid creature. She was a most gentle and affectionate animal and though she grew so tall that when striding on her hind feet she could rest her fore paws comfortably on a man's shoulders, she never showed the slightest sign of temper and whined pitifully if left alone.

In a letter, dated November 7, my brother wrote :

"Bee has just turned up looking the picture of health. He has walked every inch of the way from Loko to Gaidam on the Yo, making a very good collection through most important country. It is very nice being all in touch again. We feel now that the main part of our undertaking is practically accomplished. A fairly extensive survey right through the centre of North Nigeria, and forming a sort of 
wedge between the lines of the Anglo-French and AngloGerman Commissions is now all but finished, and if, on careful working out, every step turns out sound, the map ought to be a success. This would be almost entirely owing to our hitting upon Talbot at the eleventh hour before we came out.

"Then various collections have been made or are well in the course of being worked up, and lastly but not least, the boats have been put on Lake Chad by the exact routes and seasons promised. The Government attempt to utilise the Gongola this year for storing Bornu was largely a failure. Now we have a large store of cloth and other trade goods here which is probably the most cheaply transported stuff that has ever arrived in Bornu. . . . Bee hasn't had any malaria since his bad fever, which rather bears out what some doctors say, that a bad ' go' clears the system. The thing that put him on his legs was the visit to Lokoja where they treated him extraordinarily well. The C.O. put him up in his own house and Bee found the mess food excellent as well as a complete change.

"I am feeling very foolish at having been tied up here in inaction for so long with such a childish sickness. The doctor, a clever man, confesses his inability to explain the origin, or rather-queer course. He can only name it from the general symptoms, gastro-enteritis. ... I shall be about in a day or two now. All I have to do is to finish putting on flesh.... It is quite easy to live in Bornu practically without home stores, and you can make excellent bread, porridge, and puddings of the native-grown wheat. There are several good vegetables, and milk, rice, honey, and 
dates can generally be got. Sugar from Tripoli and occasionally tea are sold in the bigger markets."

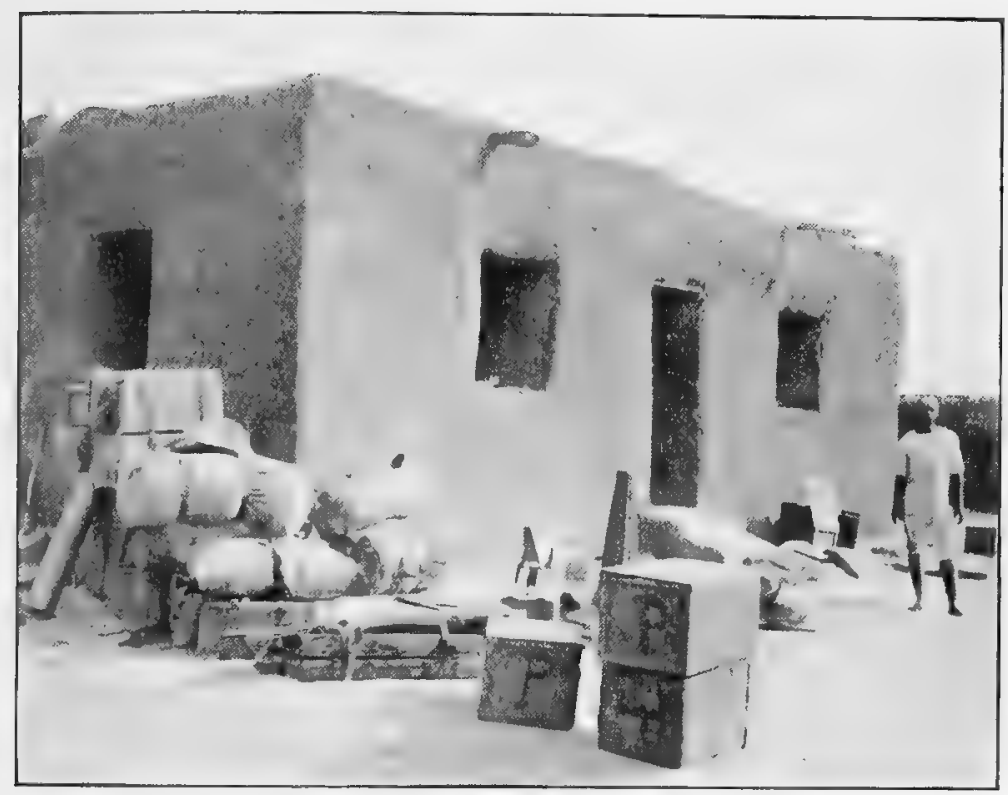

THE HOUSE IN WHICH CLAUD ALEXANDER DIED

On the 9th, Gosling left for Yo to complete his collection of fish on Lake Chad, for my brother now seemed to be making good progress. Each day raised our hopes as we watched his spirits rise with his returning strength, and his room became the most cheerful place in the fort, where we would gather of a night for talk or a concert on the gramophone. Sometimes he would ask us to send for a native musician from the village to play the sweet toned alligata pipe, marching up and down outside the house. And he would love to lie and listen, for it reminded him of the bagpipes.

But on the 11 th, just as our fears had practically vanished 
he had a sudden relapse, sinking so rapidly that we had soon to abandon all hope of his recovery in spite of the wonderfully plucky fight he made. He was cheerful to the end. Just before losing consciousness for a time, he said with a whimsical smile to Parsons, who appeared that morning with his beard shaved, "Hullo, where's the old doctor gone to?" And when Parsons readily answered, "On to the rubbish heap," his face lit up with appreciation of the prompt reply.

Two days before he died, with a tremendous effort, he sat up to write the following letter. After the first four lines, the exertion was too great for him, and the writing became illegible, so I took the pen and finished from his dictation.

"My DEAR A,-All thanks for your last letter which arrived late after the mail, and with one of mother's. . . . I have received a tremendous lot from you, and all such splendid ones; they are all so cheery I have often made an attempt to get off an answer at once, but many failures disheartened me for a time. Finally I wrote from near Bauchi, and lastly from this district. Here we are now with everything satisfactorily in hand for a fairly long stay in the area of Lake Chad. Unfortunately at the present moment I have been on my back for five weeks with a bad attack of gastro-enteritis, but I shall be on Chad in a week or two, and then there will be a good deal of work in the way of photography. I have had some tremendously cheery days lately. A good long sickness without malaria in a hot climate very often has a clearing-up effect. My best love to mother and yourself. This is going by an extraordinary mail in the morning, via Yola, which does not always succeed owing 
to the Pagans. I had a grand entertainment from the gramophone two nights ago; for some time the instrument had been laid up."

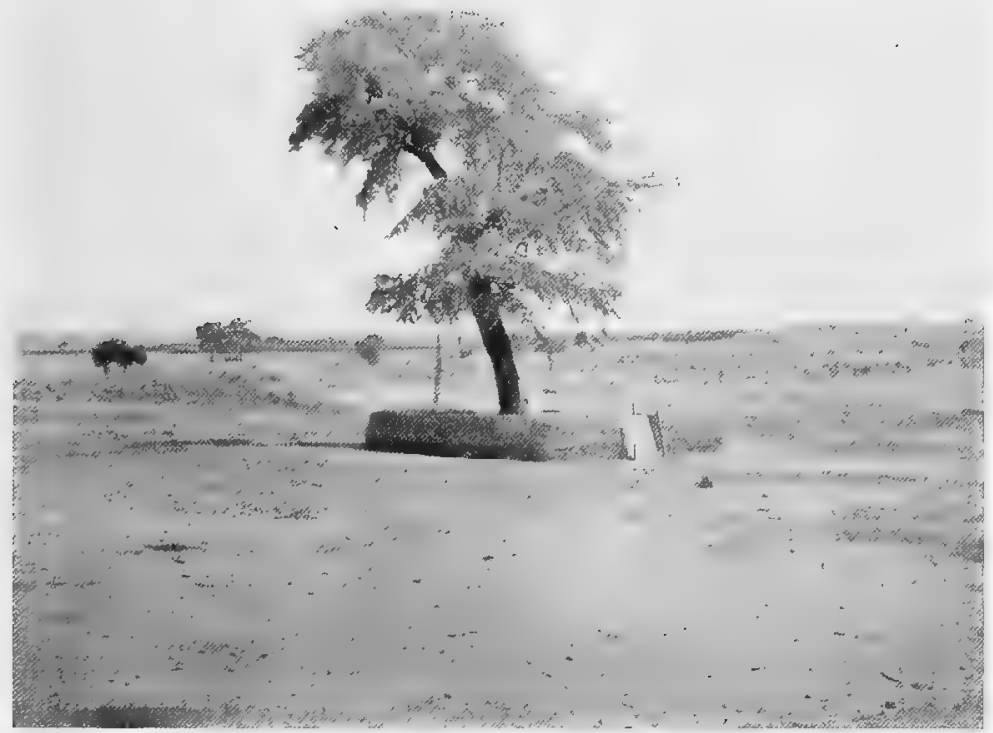

THE GRAVE OF CAPTAIN CLATD ALEXANDER

On the following night, November 12, while we were all watching round his bed, the silence was suddenly broken by the sound of a shot quite near. Parsons and Talbot went out and found an excited crowd of soldiers gathered by the guardroom, though at a safe distance, with the corner of the building between them and the door. They said that the shot must have been fired by a soldier who had been detected stealing and was placed under arrest. They could not explain how he had got hold of a rifle and ammunition, and did not like to enter as they feared he had gone mad and would shoot any one who appeared at the door. Parsons and Talbot 
went in and found that the man had shot himself through the heart.

In spite of the fast increasing weakness, my brother still fought hard for life and gave no sign that he acknowledged defeat, till a little while before the end, when he asked me to give his theodolite to Talbot; and almost the last sentence I heard him say was, "A short life but a merry one."

Death came quietly to him at the age of 26 in the evening of November 13.

When the sad news had struck the terrible blow at home, if there was anything that brought comfort to his sorrowing people it was the beautiful tribute in the following letter:

"I should like to be allowed to place my sympathy with the relatives of the late Captain Claud Alexander, whose death in Fort Maifoni I mourn in common with all the officers in this station.

"It was my privilege to have medical charge of the late Captain Alexander during his illness, and it is a very real grief to me that this illness has ended fatally.

"Captain Alexander during his illness showed a patience and a degree of unselfishness, which in my experience is as rare as it is beautiful. Never a murmur escaped his lips; and, during the time that he sojourned with us no one heard any harsh word escape him-not even his 'boys.'

"Courtesy and gentleness cannot fail to attract at any time, but when exhibited under the trying conditions of sickness, then such qualities indicate the real greatness of the man.

"The cheery optimism and active interest that Captain 
Alexander showed in his case would have delighted any medical man, while the grit and tenacity with which he fought his last fight is worthy of his race and his calling. Captain Alexander died as a soldier should die-with his face to the enemy. It is passing sad that a spirit so dauntless should pass away after such a splendid fight.

"His last moments were not spent in pain, though his mind was active to the last.

" The last utterance that I heard was, 'I'm all right now,' and surely he is.

$$
\begin{aligned}
& \text { "Allan C. Parsons, } \\
& " \text { W.A.M.S. }
\end{aligned}
$$

"Fort Maifoni,

"Nov. 14, 1904."

He was buried the next morning, with full military honours. The body, which was wrapped in a blanket and covered with the Union Jack, was met outside the fort by Lieutenant Farmer and the full company of soldiers, who presented arms. From that point Lieutenant Farmer joined the bearers, Parsons, Talbot, and Sergeant Moon, who placed themselves on the right of the company. Then, making a half-right turn the procession marched slowly to the grave, beneath an acacia-tree to the south of the fort, where the road passes to Yola. Here his body was laid to rest, with no coffin boards, but lying softly in the lap of earth, and Dr. Parsons, the friend who had given his skill and all the kindness from the rich store of his heart to help his patient in his brave fight, performed the last office and read the splendid service for the burial of the dead. Then three 
volleys rang out over the grave, and we said the long farewell to a dear brother, brave soldier, and delightful friend.

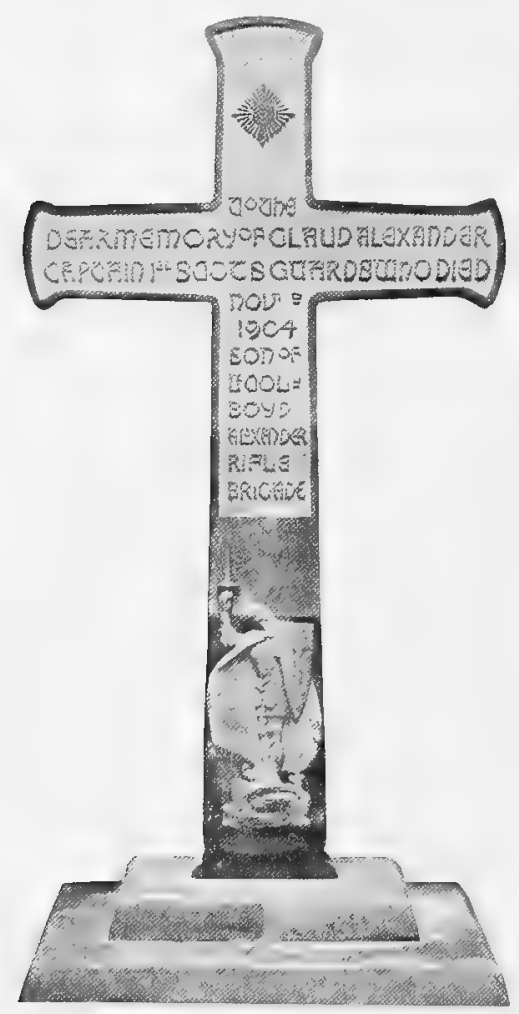

CROSS SET UP OVER THE GRAVE

In the afternoon I went for a ramble in the bush and gathered flowers to deck the grave. This was not the season for flowers, but I was fortunate in finding an abundance of pale purple thistles, that formed an appropriate offering. Next day all the little children from the Freed Slaves' Home in charge of the old matron made journeys to and from the river, bringing mud in calabashes, and in two days they had built a wall round the grave, the little things enjoying the work hugely. Two months later, when I returned to Maifoni from Lake Chad, I found a cross set up over the grave. It had been very cleverly constructed by Lieutenant Farmer and Sergeant Moon out of the tin linings of ammunition boxes filled with clay, for wood will not stand the attack of the white ants. But now a very beautiful cross, the work of Mr. Alexander Fisher, has taken its place. It is made of polyphant, with a figure of St. George and the badge of the Scots Guards in bronze upon the stem. As it had to be carried for 
many days on the heads of men, it was necessary to have it constructed of separate blocks weighing not more than 60 lb. each. The cross was set up at Maifoni by Dr. Parsons just within a year of its leaving England. He also rebuilt the walls round the grave, cementing in native spear-heads round the top. Of course, the difficulty of conveying so heavy yet so delicate a work of art over all those rough miles was enormous, nor would it have been possible without the kind help of Dr. Parsons and Captain Elliot.

I like to think that though my brother died so far away from home, fate permitted that

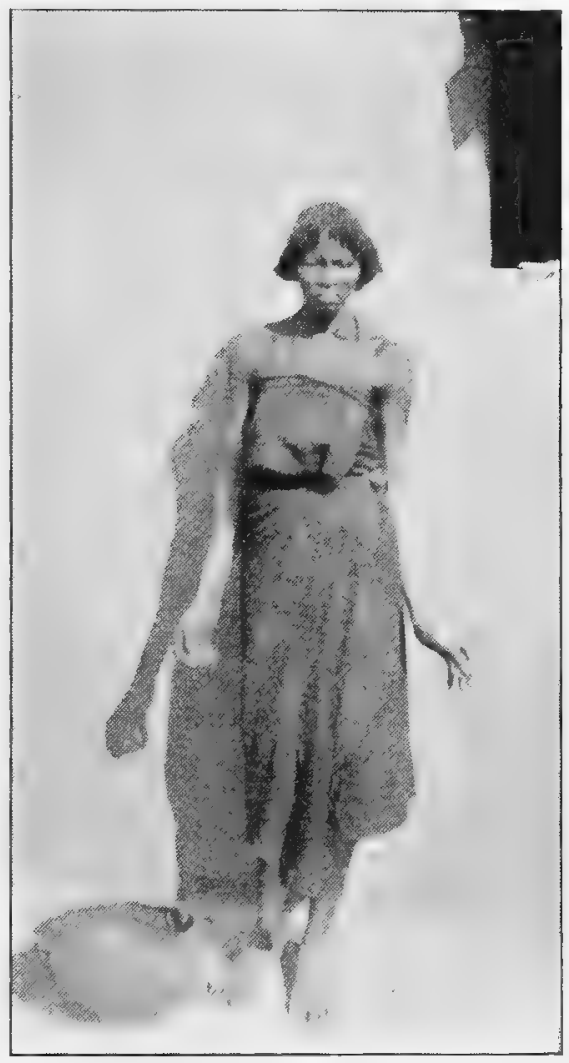

A KANURI WOMAN AT MAIFUNI

flowers should rest and children laugh and play about his grave. For if there were two things in this world that his soul loved, they were flowers and children. I can remember how, even when he ran home on leave for a single night, he would always go into the garden to pick a nosegay for his bedside if it had been forgotten. Or, 
if one had remembered his fondness and placed some flowers on his dressing-table, one would be touched to find on going into his room in the morning, that they had been brought to a chair by his bedside where he could see them on first waking. When he was on block-house duty in South Africa, he made his temporary prison quite pretty and cheerful with a well-laid-out garden, and there are several photographs of his camping-ground on trek which show that when the halt was too short for plants to grow, bower-bird like he would deck his tent with cut flowers and the entrance with branches.

During the South African War, a young theatrical manager ( $\mathrm{I}$ forget his name) by a stroke of genius hit upon a most original scheme and brought a company of children from Australia, training them upon the voyage to act, and dance, and sing. He then opened the theatres at all the chief towns of South Africa with plays performed by his child-company. And it is strange to think of, that often when the country just outside was in a state of war, the people of the town and the soldiers of the garrison could go to the theatre and see happy little children romping through a play. At first the performers were rather more quaint than precise, but soon with the constant practice two or three discovered real genius. But nearly all became good actors, for almost all children have inspiration, and it was not long before they were giving such ambitious pieces as The Belle of New York and even Carmen. It was natural that my brother should very soon discover them, and they were to him such a joy that he never missed an opportunity of seeing them play or of 
organising some little party or picnic for their pleasurc. The little prima donna, Ina Milne, about fourteen years of age, had a most wonderful album in which she was collecting signatures, sketches, and verses from all her friends, British and Boer alike. The interesting collection contained such famous names as Roberts and Kitchener, and many Boer leaders also, among them, I believe, De Wet. My brother, who had a pretty knack for writing verse, inscribed the following anagram, writing the first letter of each line in decorative character, suggesting Chinese.

"If I write like the people of China

Now, I'll fill the whole length of this page

Attempting to name and define a

Most brilliant star of the stage.

If their methods are better than mine are,

Leastways it's as clear as the sun

Not more than three letters spell INA,

Even less in the symbol "A 1."

But I had not these lines in mind when I commenced to speak of the company of little friends. Rather, I was thinking of the occasion at the end of the war, when they had a farewell party at Durban on the eve of his departure for England and theirs for Australia. I know he felt the parting very much and once more he wrote in his little friend's book a few lines, with which I will conclude this brief note on his personality.

"My children, if before Life's curtain falls

You'd all engage to join the Heavenly choir,

I'd turn a Ieaf and book eternal stalls

And save me from the pit of endless fire." 
[Note.-The following record appeared in the February number, 1905, of the Household Brigade Magazine.]

\section{THE LATE CAPTAIN CLAUD ALEXANDER}

It is with the deepest regret that we have to announce the sad and premature death of Captain Claud Alexander, Scots Guards, which took place on November 13 of last year, in Northern Nigeria, where he was engaged in a scientific and surveying expedition. $\mathrm{He}$ had already surveyed over eight hundred square miles of country, when his untimely death from enteric fever put an end, for the present, to a work which will probably be of the greatest service to his country.

Captain Alexander was the youngest son of Lieutenant-Colonel Boyd Alexander, late of the Rifle Brigade, and joined the Scots Guards in 1898, was promoted lieutenant in 1900 , and captain in $1904 . \mathrm{He}$ served throughout the South African War from 1899 to 1902, and was wounded at Belmont, for his gallantry on which occasion he was mentioned in Lord Methuen's despatches. He received the Queen's medal with five clasps, and the King's with two; he was also in possession of the diploma of the Royal Geographical Society.

A most promising and popular officer, he dies regretted by his comrades of all ranks, and our deepest sympathies are with his relatives in their bereavement.

A memorial service, held in the Guards' Chapel on the 17th inst., was largely attended by the officers, non-commissioned officers, and men of the Scots Guards. 


\section{CHAPTER XIII}

FROM MAIFONI TO KUKAWA

Tre sadness of the last terrible days at Maifoni weighed with continuing heaviness upon my mind, and my thoughts kept weaving across the gloom pictures of my brother's last illness and death. There were also the uncertain, haunting fears of the blow my cable must by now have struck at home, with no hope of news for many months to come; and, as it afterwards proved, more than a year passed before I received a letter from home.

It was impossible to stay still, and work came as the only means of relief. But at first, I found it very difficult to concentrate my powers; effort groped in the darkness that enveloped my thoughts, and struck out aimlessly like one beating the air. But, more than ever did I feel the necessity to keep on straining every nerve to carry the work through to a successful end, and so justify the launching of an enterprise that had already cost us so terribly dear. So sorrow was buried deep in the heart and covered with silence, where it lay with leaden weight for many days. But the dews of heaven, passing over all, do not leave even the graves unvisited, and after a while flowers began to spring in my vale of desolation from work's boon and Talbot's tender sympathy, and once more the world began to move for me and weary miles were put behind. 
Leaving Maifoni on November 16, Talbot and I started to complete the last portion of the survey, which was to connect our line with Kukawa and so finish the Nigerian portion of the map. Gosling had preceded us along the road on his return to Yo to shift the base camp to a site I had already selected on the shore of the Lake.

The survey work was now straightforward, comprising chain work along an excellent government road, which connects Maifoni with Kukawa. But progress was slow as every inch of the way had to be measured between points fixed by the theodolite, and sometimes intervening bush or crops had to be cut down. In the latter case, compensation in cloth was always paid to the owners. Altogether, we were about three weeks covering a distance that under ordinary circumstances would take five days. The road led through flat country the whole way, a broad plain in fact, of rich dark soil, which is widely cultivated with guinea-corn where the ground has been cleared. For the rest, there are stretches of thin grass and frequent groves of mimosa bush. Occasionally, the general monotony of these small features is relieved by a group of well-grown fig-trees, which mark the presence of water, either in little pools or wells. But for them the country is waterless. These wells and waterholes are to be found at intervals along the road, and we always arranged to camp near one each night. Some of the wells are deep, as much as sixty and eighty feet. They are generally points of attraction for the life of the surrounding country. Sometimes they are under the charge of a native, who lets down the waterskin for the thirsty. At those near a village groups of women are to be seen morning and evening waiting their 
turn, with their pots standing in rows, while two or three are employed letting the waterskin up and down. At the waterholes, when the supply has been exhausted by the continual dipping of calabashes, the women sit down and wait

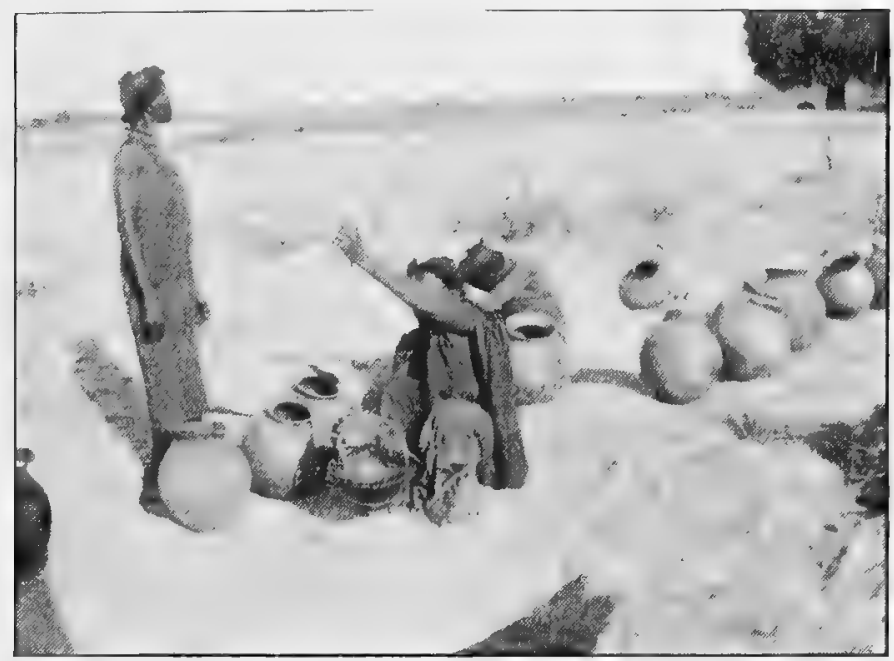

WAITING FOR THE WATER HOLE TO FILL

till the holes fill up afresh. As one sights the spot down the road ahead where a well will be found, by its guardian group of shady trees, or guesses at its nearness from the sound of voices or the lowing of cattle, there is always a feeling of joy in one's heart, for the well generally marks the campingground at the end of a long day's journey or the resting-place from the heat of the noon-day.

But, even if one has not come thirsty and tired to the refreshment that it offers, there is always the little picture of wayside life to cheer the eye after the long stretch of dull, monotonous road. Besides the picturesque groups of women waiting while their pots fill, or coming or going shouldering 
their pots in line on the bush path from the neighbouring village whither they carry back with them the wayfarers' tales; perhaps there is also a halting caravan, the drivers watering their tired and thirsty beasts, which are for the time freed of their loads. Truth is said to lie at the bottom of a well, and surely beauty is always found at its surface. There is a happy mating of meaning in the very word. Here Earth bares her breasts to all her children, and trees and beasts and men alike drink of her strength. In our childhood's stories what significance lay in the name of a well! In the sweetest fairy tales how often has imagination drunk its fill at the Magic Well! And in the Book of Life itself, history has paused at the well-side to tell some of her most beautiful stories. It was at a desert well that Hagar brought life to her little boy, and at a well Jacob saw Rachel and lifted up his voice and wept for very tenderness of love. Out of a well came a ruler over Egypt, and a woman once stood beside one in Samaria and listened to the wisdom of Heaven.

Even in green England the village pump crowns the market square, and here are always to be seen the prettiest groups; the children playing on the steps, the wayfarer drinking, and the girls balancing their buckets as they descend with moments of poise so beautiful, that it would almost make Niobe weep because they are not turned to stone. Yet, here in England more than half the romance that once lingered round a well, has been stolen by the too frequent roadside inn. So, imagine what significance attaches to it, in a country of fierce heat where wind-storms drive the sand across the miles of scorched plain, and travellers 


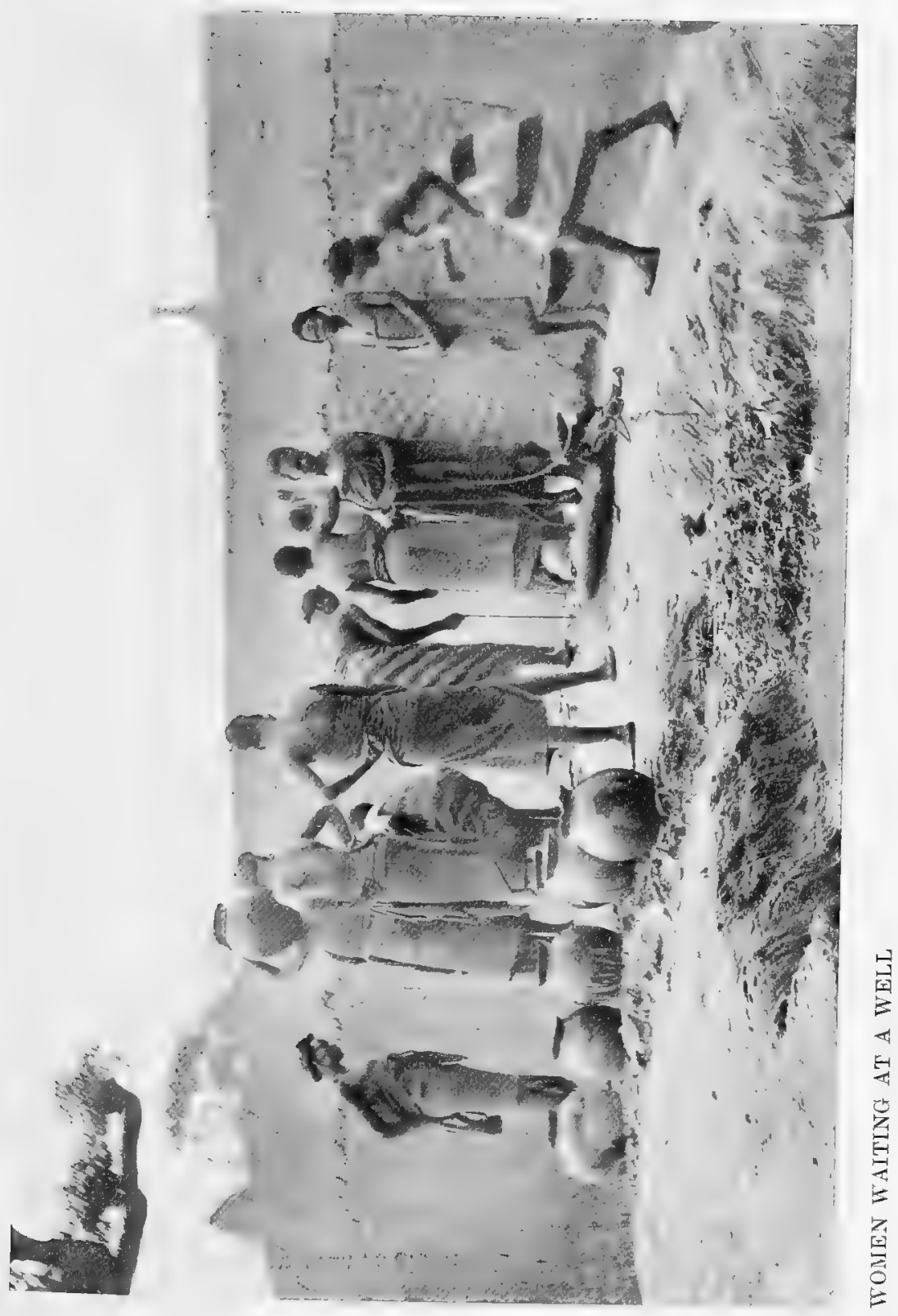



and beasts struggle the long day through to reach the living waters of the well at its end !

A little way on the road from Maifoni one passes Maidugari,

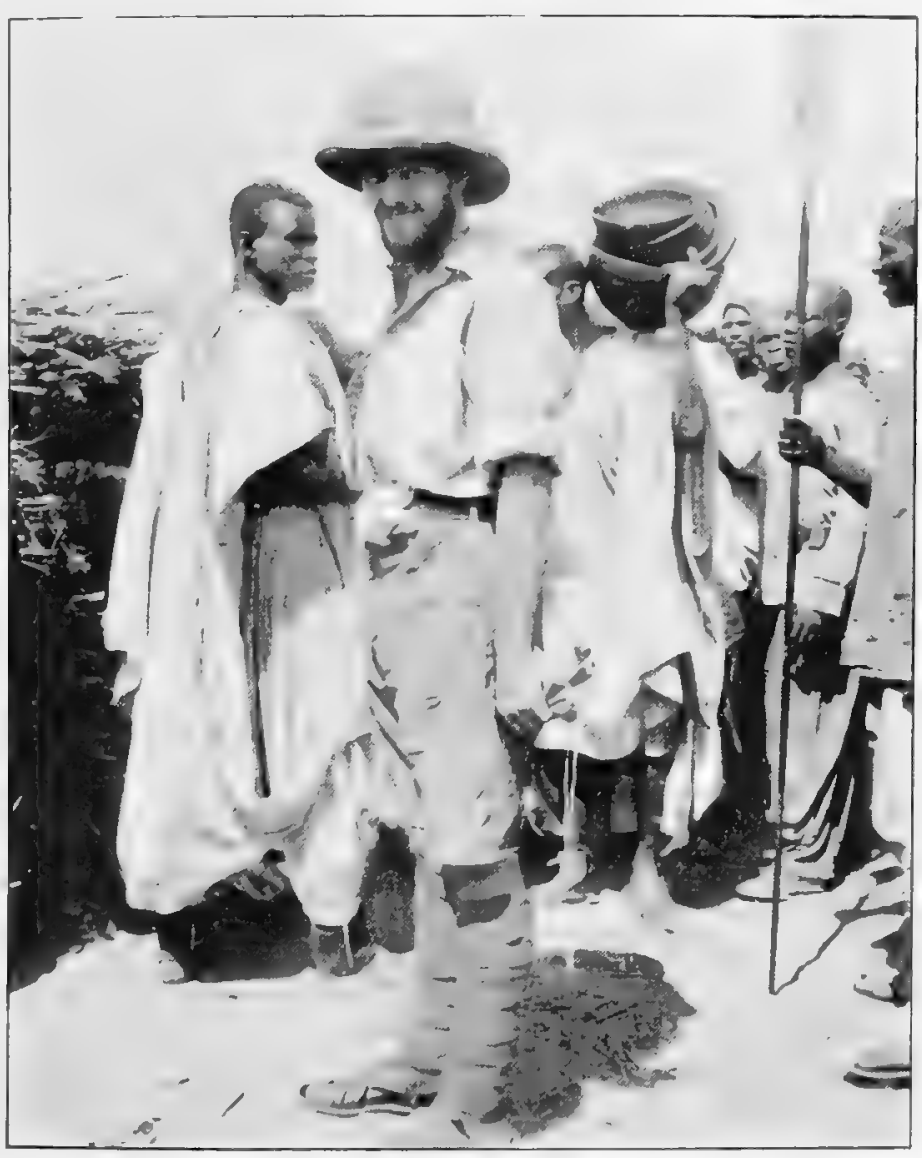

TALBOT AT MAIDUGARI MARKET

the largest market of Bornu, for it stands in the centre of the fertile part of the province and represents its industrial capital. It is composed of lines of sheds and stalls, covering a large area, but empty of life save on the weekly market day, 
for, as with most native markets, no village has sprung up in proximity to the stalls and the nearest habitation is half a mile distant. But on the market day the whole place starts suddenly into life, presenting most varied pictures and the liveliest scenes. There is a market king, to whom the merchants and the buyers bring their disputes to be settled, and for their protection the women choose a queen. It is not custom to buy directly from the women's stalls and nearly all transactions are carried on through the queen. Except for the heat, many hours can be pleasantly spent surveying the ever-changing scene with its mixture of colours and sounds, and studying the various types and the mingling interests of the men and women who here meet to buy and sell. In the busy throng are to be seen the wandering Shuas standing by their tethered oxen which have brought in sacks of grain; the Fulani by his sheep and goats in stall; the Kanembu merchant from Kowa with piled slabs of potash and dried fish that he has bought from the Budumas of Lake Chad, and the big balls of blue dye for the dyeing of cloth. Here come Hausas from many parts, some from far-off Kano to buy the renowned cattle of Bornu; others, who are weavers and plaiters, to sell their wares of cloth and straw, bernouses and hats, and little parchment boxes that contain blue chalk, beloved of the women for painting their eyes, and little brushes of frayed bark wherewith to lay it on. The Kanuri women from the country round bring butter and milk, and cakes made sweet with butter, monkey-nuts, yams and chilis, and a root that makes good soup. There are leather-workers, too, with saddles and shoes, and the high leathern gaiters that horsemen wear. 
Cattle and sheep are slaughtered in the market and the meat sold in little heaps upon the ground. And the shed is crowded where the barber plies his trade, rubbing on water and shaving the heads of his patrons who squat before him. Here I went through the process of a joke that I played with unvarying success in all the markets I visited. Attracting the attention of the barber, with rigid, outstretched fingers I made an expressive movement across my upturned throat, then pointed commandingly to the man he was shaving at the time. This little piece of pantomime was invariably received by the crowd, who follow every movement of the white man, with a roar of merriment which did not subside for quite a long time, and in which the victim of the joke joined with such convulsive appreciation that it was some time before the barber could continue operating, for fear of actually producing the drama that my gestures had indicated.

Sometimes the large Arab caravans coming from Tripoli to trade with Kukawa, find their way as far as Maidugari, and their stalls of mixed goods from far-off countries add interesting variety to the usual native produce. With them they bring large cones of sugar, bright stuffs and rugs of many colours; striped linen and sometimes pieces of sil's, and strings of keads for the women and sword-blades for the men.

As one threads a way through the crowds round the stalls, it is interesting to compare the many types and races who have met together to buy and sell, yet who never mix in friendly intercourse beyond their business. The big men of the neighbourhood come in, dressed in their richest clothes 
and wearing swords, and with their boys behind, bearing their much-prized guns. And there are many women, too, in the crowd in bright raiment and with blue-painted eyes, and hair elaborately attired and drenched in oil.

Here are the Kanuri, moving apart with dignity as becomes the possessors of the land, tall and well-bred looking, courteous and generous to the people of their own race and to the stranger within their gates; but despising the Hausas, who will stoop to carry the white man's loads for the sake of gain, or go, so the others say, any distance and employ any means to drive a hard bargain. Then there are the quiet and silent Shuas, the drovers and shepherds, who, like gypsies, are distrusted by all, and keep to themselves. And again one marks the high-featured Arab, proud and condescending in mien, like the travelled man he is, from an old civilisation come among barbarians.

It is amusing to watch some of the fashions of greeting. Two Hausas will meet, first cross themselves, then hold each other by the hand not letting go till they have finished their salutation. This is always in the same terms and like the following dialogue:

1st Hausa. "Hail! Is it well with you ?"

2nd Hausa. "It is well."

1st Hausa. "Allah be praised for that! Is it well with your wives?"

2nd Hausa. "It is well."

1st Hausa. "Allah be praised! Is it well with your children ?"

2nd Hausa. "They are well."

1st Hausa. "'llah be praised! And your horse?" 
2nd Hausa. "It is well."

1st Hausa. "'llah be praised! Your cattle?"

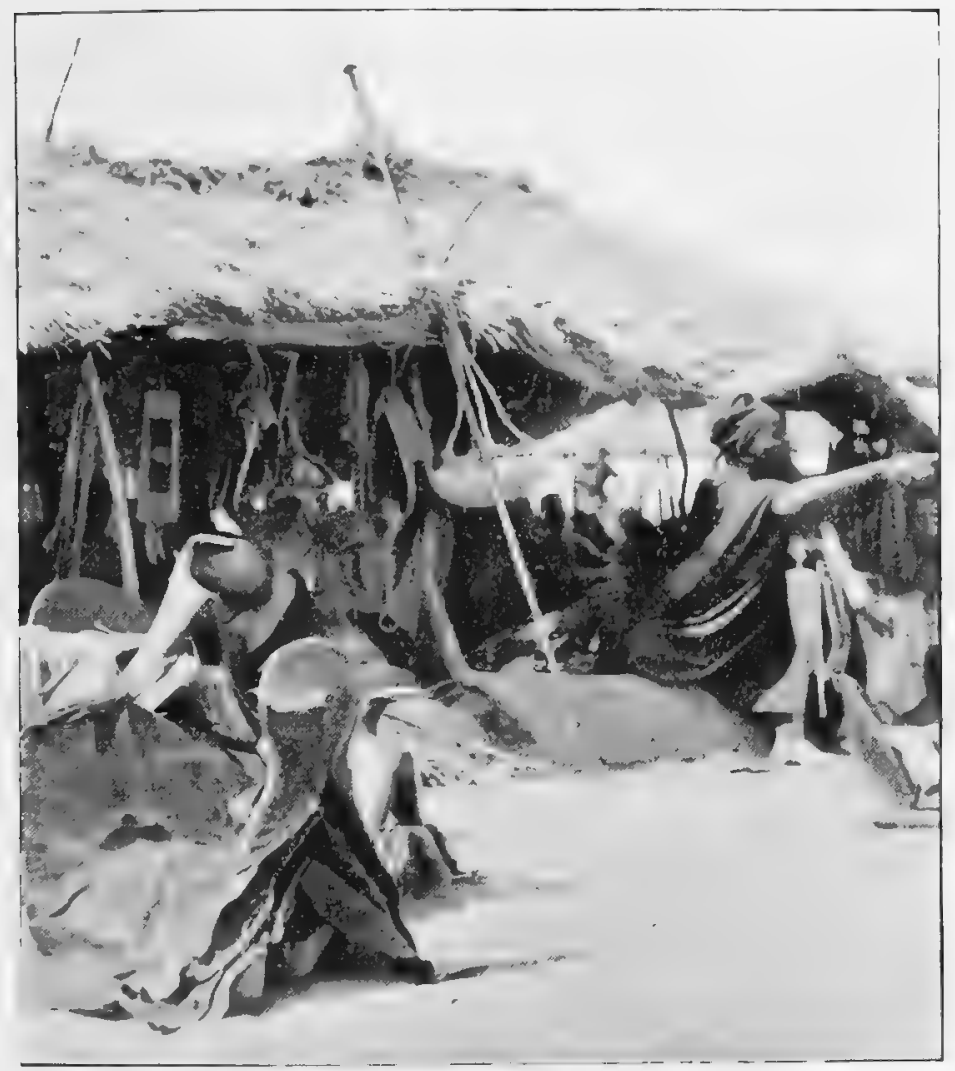

SADDLER'S STALL IN MAIDUGARI MARIKT

2nd Hausa. "They are well."

1st Hausa. "'llah be praised! Your house and all that is yours?"

2nd Hausa. "All is well."

1st Hausa. "Allah be praised."

And then they pass their ways and the same thing is repeated with the next friend they meet. The Shuas on 
the other hand, do not waste much time in talking, and, as they go about their business, just shake fists in the faces of any friends their eyes may light on. I remember I was much surprised and amused the first time a Shua cattle-drover shook his fist at me on the road, and I puzzled for long to find an origin in the gesture, for there are always interesting reasons, if only they can be traced, for the variations in forms of greeting.

As we all know, the hand-shake originally signified an assurance that no weapon was concealed, and I have sometimes wondered if the pledging in a cup of wine could not be traced to the idea that while the lips are closed upon the cup they can speak no ill. Working on the same system of deduction, I imagine that the fashion which the Kanembus have of taking one's hand in both of theirs is derived from the custom peculiar to this tribe of going about armed with bow in one hand and spear in the other. A Buduma chief greets one on approach by raising the right hand extended like a priest's in blessing, as if to show that he carries no arms, while his women kneel, abasing themselves, with arms outstretched in oriental fashion, which supports the tradition that the Budumas originated eastward in Kanem, and so would have come under the influence of the farther East.

As regards the Shua and his peculiar form of greeting by shaking his fist in the face of a friend, I found out afterwards that it was to be attributed to a constant habit of carrying his string of small praying beads wound round the palm of his right hand.

Now the Kanuri greet the white man on the road with a clapping of hands, and I can only imagine that this is 
intended as a graceful way (for they are polite people) of saying that they think his progress more or less triumphal through the land.

Before leaving the subject of native greetings, I might

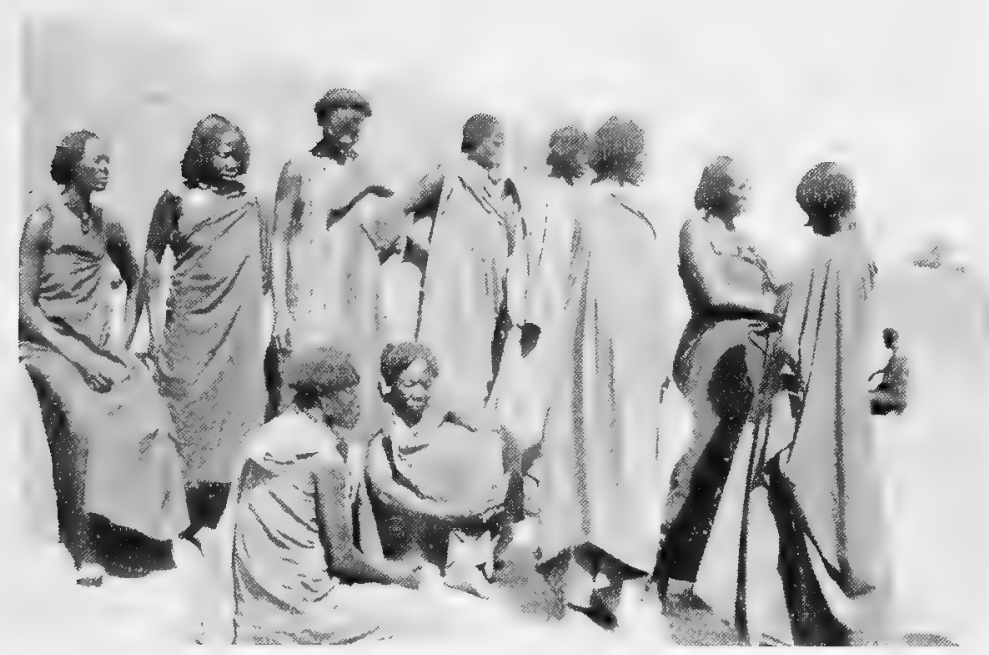

SHUA AND KANURI WOMEN

mention that some of the more simple Pagans salute the white man by falling to the ground and throwing earth over themselves. Can it be that they wish to imply that they are worms in his sight?

After leaving the market of Maidugari there is little to record of the journey. The chain-work on the road kept both of us occupied the whole way, and I did not make very many excursions into the country for birds, as I found the distribution poor, the only one of interest being the black-breasted bustard (Ctis melanogaster), a beautiful bird which favours 
the dry grass plains. And there is little or no game to be found, partly owing to the want of water, and partly to the populousness of the neighbourhood. But though the time was uneventful, it was interesting for the opportunity it afforded for studying the natives, whose villages are frequent along the road. The only three, through which the road actually passes after Maidugari, are the Kanuri villages of Marsu, Wulo and Mongonnu. At these we were treated very well by the chiefs, who came with large "dashes;" the usual fowls and eggs for ourselves; and for the "boys" calabashes containing shapes of ground millet, made by the contents of a smaller calabash being turned out into a larger and surrounded by a sauce of meat spiced with chilis. As well as these there were calabashes heaped up with green food, and all was piping hot. On these occasions it was always the duty of the cook's mate, Lowi, to bring forward a bowl of water to try the eggs by ordeal. Out of a dozen it was not unusual for five to float, which the chief would take back, with an absolute composure of countenance that betrayed long habit, to be stored till the passing of the next white man, and so on, if rejected, till they burst.

The villages of the Shuas are numerous in this part, for it represents the heart of their country. They are never to be found upon the road but always a little way off in the bush. This may be owing partly to their secret nature, but the Kanuri say it is because the Shuas are mean and hate to have to give to the travellers on the road. The natives of Africa, with a few exceptions, have the sense of hospitality remarkably developed, and no traveller upon the road is allowed to pass hungry. So there are no houses found in a 


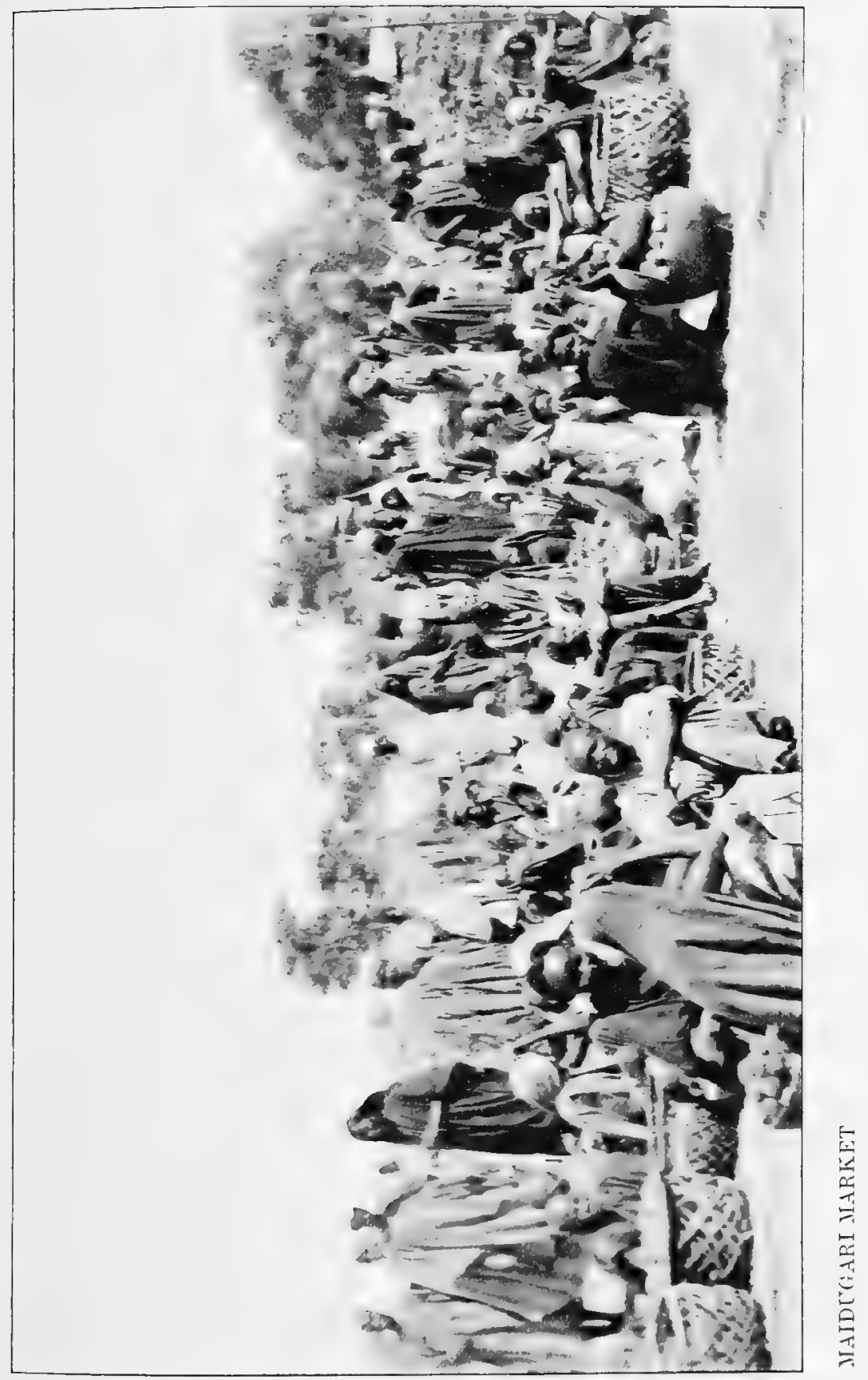



native village resembling inns. where foud and forage are sold, but the whole village is one large lustelry for all the world

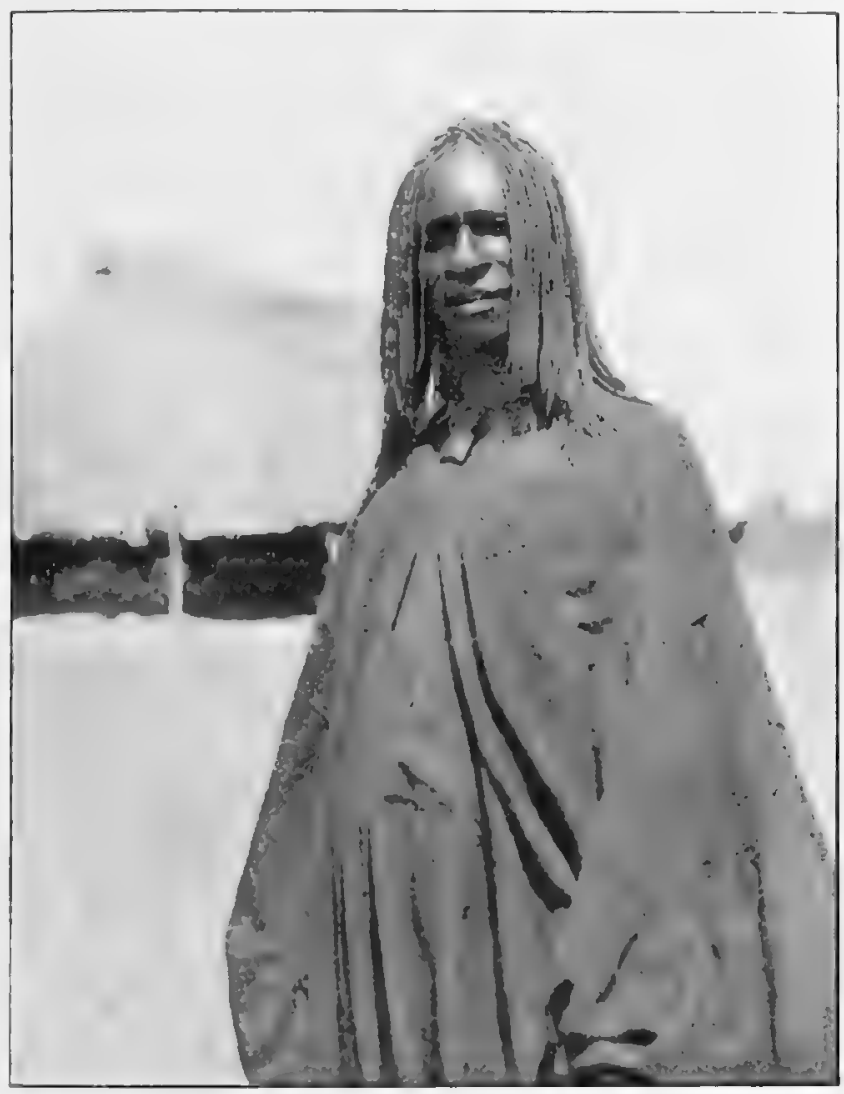

PORTRAIT OF A SHUA GENTLEMAN

that passes its dowr, and every native is the host. I believe that a man could travel from one end of Africil to the other without taking any money or provision whatsocever. and, so long as he went alone and unarmed, would always be fed and helped by the natives.

With most blacks curiosity amounts to al passiom, and 
seldom himself moving far from home, the native loves to watch the life that passes on the road, and the traveller

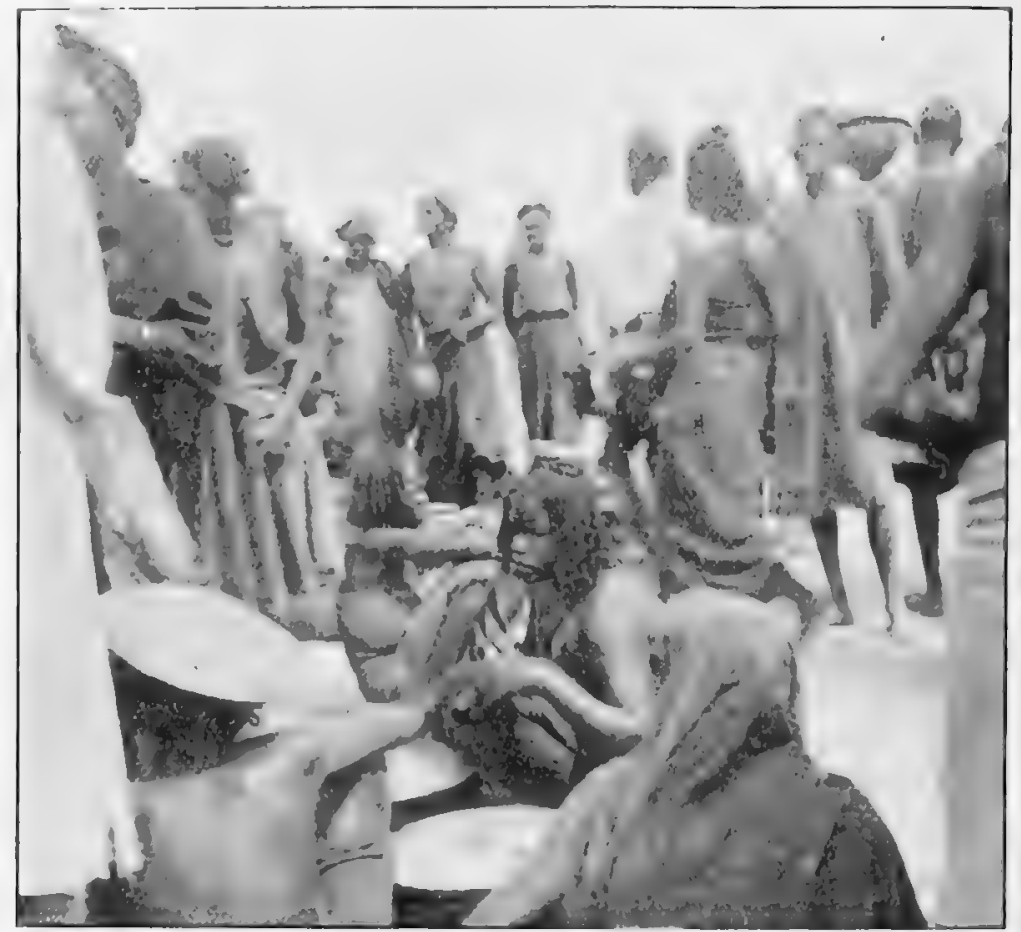

A SHUA MARKET NN BORNU

(even the one who has not gone farther than the next country), who can bring him news and tell him of things that his own eyes have never seen, is a great man in his estimation and worthy to be entertained.

The characteristics of the Shua people forcibly suggest their originating from Abysinia; the similarity of the name Shua with that of an Ahyssinian people, called Shoa, bears this mut. Their type and habits also, and their inborn love of horses-for lonse-breeding is the 
chief aim of their existence-go further to strengthen this supposition. They are essentially a pastoral people, leading a patriarchal sort of life, driving their flocks and herds from one ground to another according to the seasons and the supply of grass. So they are never in a place for very long at a time, and leave one village to establish themselves in another where there is fresh grazing for their cattle. They are pale in complexion for West Africans. The women strike one as being of finer physique

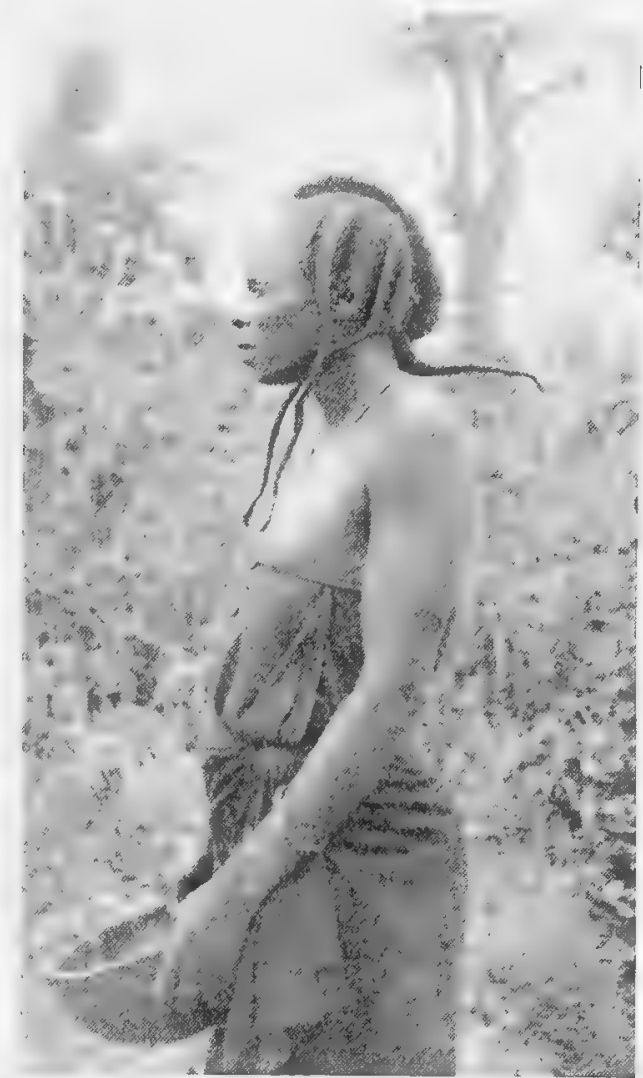

$\triangle$ SHUA WOMAN than the men: they are long of limb, regular in feature, with almond-shaped eyes; their hair is most luxuriant, and the manner of dressing it in numbers of fine plaits, which fall like the fringe of a curtain, forms a most decorative setting to the face. On market-day the women take still more trouble with the tiring of their hair, subjecting the plaits to an 
extra twist and saturating their heads with nut oil that runs down in streaks upon their naked shoulders.

The Shuas are true children of Noah, and their huts at night afford shelter to man and beast alike. Horses, dogs and cattle, pigs and fowls, all share a common stall with the family. I noticed that their dogs, in fact most of the dogs in this part of the country, had half their ears cut off. The natives always said that their reason for cutting them was to make the dogs run faster!

And that reminds me I must here introduce to the reader a new member of the Expedition. One day while I was out shooting birds in the bush not far from a Shua village, I heard a pitifal whining, and going in the direction whence it came, discovered about a handful of puppy, mostly made up of two large, distressful eyes whose appeal I could not resist, so I put the soft little lump in my pocket and carried it home to camp. The poor little wretch was the victim of a Shua custom of throwing away the male puppies of a litter in the bush to die; so, unlike the dogs which the shuas keep, he had the distinction of carrying uncropped ears; for it was supposed that his race would be so quickly run that it would not be necessary to hasten his pace, and-rather like the little dog in the old song-as his life was cut short his ears were cut long. But my chance discovery of him averted this fate, and in a very short time he showed his gratitude by employing his prolonged existence in growing well up to his ears, and soon he was large enough to support the name of "Maifoni." If he could be classed under any breed one would say he was the terrier type. 
His coat was smooth and cream-coloured, with a white spot on the back of his neck, and he had four neat little white socks.

About 600 yards away to the left of the road, between Mongonnu and Kukawa, we came upon the vision of a beautiful lake, lying in the open plain and about a quarter of a mile in length. It was a gracious sight in such a waterless land and I rode towards it with delight. Talbot, too, hailed it with joy as lending variation to the details of his map. But when we got almost up to it, it vanished away with extraordinary suddenness, and we discovered that we had been led by "the mocking mirage of the wilderness."

Next day we reached Kukawa, the goal of our survey. The market was in full swing when we arrived and our coming caused no small stir among the large crowds that were gathered round the stalls.

Meanwhile, our carriers, who had now been eight months engaged on work of which they were none too fond, entailing submission to a discipline unusual to them, here finally laid down their burdens. Consequently their enthusiasm knew no bounds, and it was quickly communicated to the people in the market, who added their voices to the general acclamation, not understanding in the least, I am sure, what all the excitement was about, but instinctively realising that people when happy are apt to lighten their purses with their hearts. And they were right; for no sooner had the "boys" been paid than they overran the market and converted their coin into kind.

Talbot now placed the theodolite into position, and adjusting his sight on a stone which marked Colonel Jackson's 
fixing of Kukawa, completed the last square in the map. And the solemnity with which the mysterious instrument was treated, suggesting a complicated ritual, made all the assembled people feel that they were witnesses at the celebration of some great event. 


\section{CHAPTER XIV}

THE SHEHU OF KUKAWA

THe survey in Nigeria being finished at this point, our attention was now to be turned to the exploration of Lake

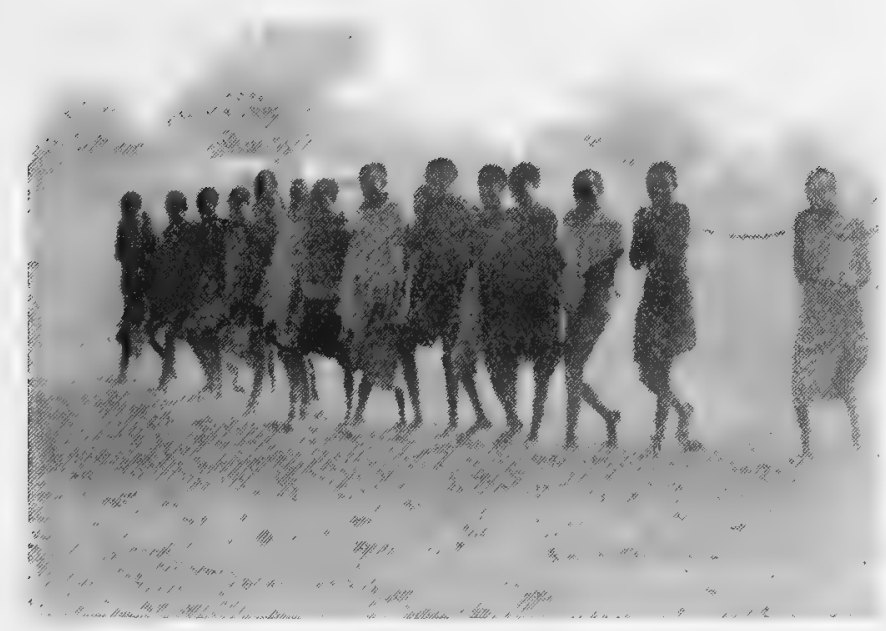

A STRING OF THE SHEHU'S PRISONERS

Chad. But, before leaving Kukawa, we thought it would be politic to pay a visit to the Shehu, or Sultan, of the country. To give the reader an idea of this man's importance, I might say that he is the paramount ruler (that is to say, under British control) over the province of Bornu, which is, 
roughly speaking, as large as England. So, having sent word previously that we would come and see him. Talbot and I mounted our horses and rode up to his palace.

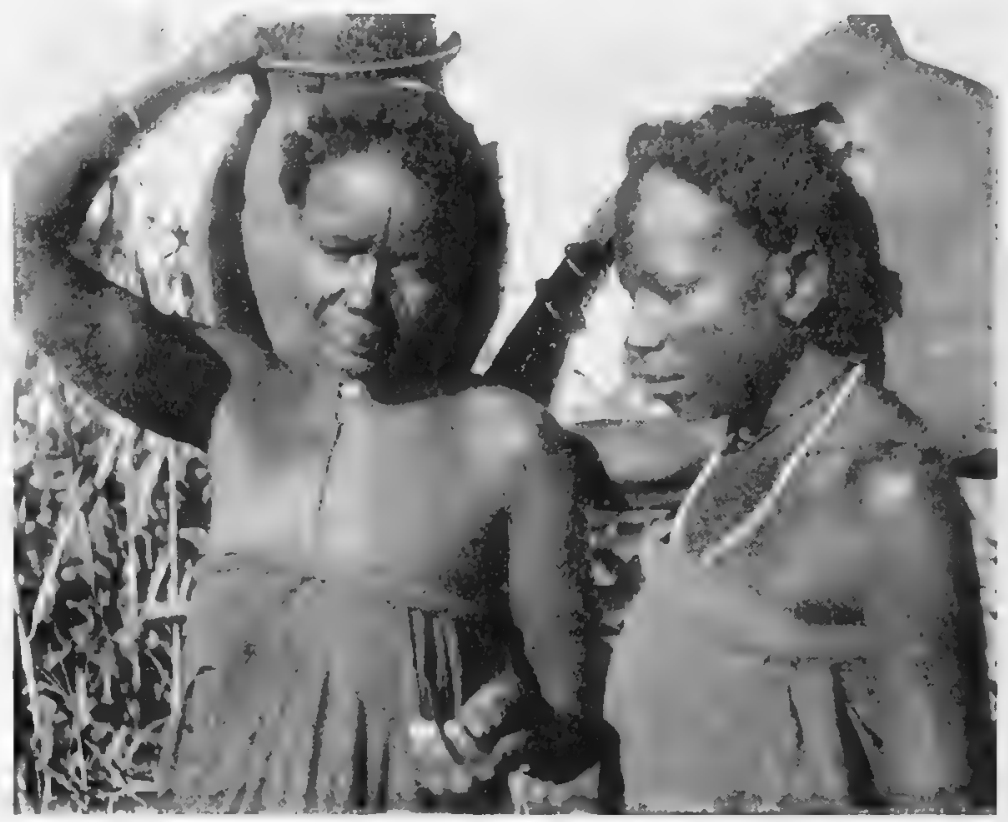

KANURI WOMEN

In the road thither wo mot, a string of about sixteen of the sultims prisumors, all chained together nock to neck: thre ware on their way to work on the restoration of the palace of the old sultan, Kiari. He was the father of the present man, whose name is Gaurobil. Kiari, unlike his son, was a very warlike king, always fighting for the love of the thing, and comserpurently no friend of the white man, whose coming, the nation woll knows, brings peale. But one day he mot his match in the chice, Rabeh, the great seourge of rentral Africal, about whom we shall have more to say 
presently. Though defeated by him in a fierce battle, Kiari would not submit, and when Rabeh rode up in person to lead

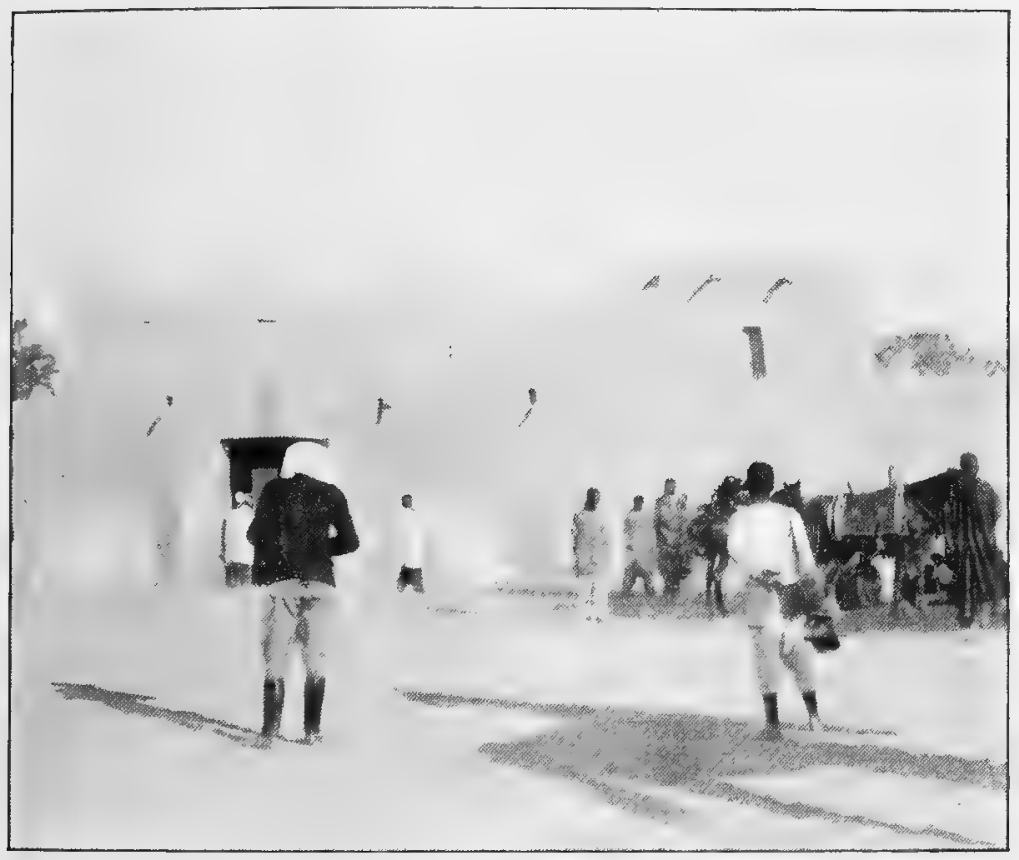

TAE SHEHU'S PALACE

him back on foot in triumph as his prisoner, Kiari cursed his victor and begged to be killed, saying that the women of Bornu should never see him walk behind any man. But Rabeh, a splendid warrior himself, recognised a worthy foeman in his captive and loved him. So he would not kill him; but as Kiari refused to walk, set him bound upon a horse and carried him into Dikwa. Here Rabeh had him brought into his presence daily, using all persuasion to gain his submission and offering to make him general of his forces. But Kiari only renewed his curses, saying that he himself 
was a king and would die as a king. Whereupon Rabeh grew weary and handed him over to his son, Faderellah, who, saying he could manage him, took him away and hanged him.

It was at this time that Rabeh hal sacked Kukawa, demolishing the northern part of the town, where the old palace stood. This happened in December 1893, and to this day one passes through about a mile of the town where the houses are all in ruins.

As I related above, the gang of prisoners that we met on the morning of our visit to the Emir were on their way to work at the restoration of Kiari's palace. Their appearance was miserable in the extreme, suggesting semi-starvation, and my imagination would have painted the potentate we were about to have audience of in the colours of an ogre, had not a chance, unofficial sight of him, recorded by my camera when he was mounted at review of his troops the dar before, given me a reassuring impression of his personality. The palace is an imposing building and, though made of mud, has pretensions to architectural design of Egyptian character. It has a frontage of some $60 \mathrm{ft}$, and faces the broad street of the town leading from the market. On the morning of our visit I could not help being forcibly struck by the picturesqueness of the building and its surrcundings. In front of us the walls, sun-baked to a hard white, stood sharpcut against the soft blue sky and, sloping from their base, rose to a height of about $30 \mathrm{ft}$., which made them seem impressive, in comparison to other houses in the town.

The palace altogether covers a large area. Besides the living-rooms there are rooms or houses for the dead within 
its walls also. There are six of these already tenanted by former Sultans of Bornu, who rest beneath the floors, and are feasted once a year with a sacrifice of cattle that go to them through the mouths of the poor at the palace gates.

On the right a few trees form a wing and cast a deep shadow which affords a grateful shelter for the waiting horses and slaves of the headmen of the district who come to seek audience of the Shehu. This is a daily function, and it is an amusing sight to see these fat, lazy, pride-swollen chiefs being lifted in and out of their armchair-like saddles by their slave boys, who are forced to run as best they may behind.

With them, too, come their friends on foot, of lesser rank, but who eat, nevertheless, at the big men's tables, forming an audience for their masters, as the latter do for the Shehu. While the big men are admitted within the palace, their friends, who are not so favoured, wait outside and form their own little courts among their patrons' slaves. Thus the vanity of all grades is mutually satisfied, and the lines in "Hudibras" are again illustrated:

"Big fleas have little fleas

On their backs to bite 'em.

Little fleas have smaller fleas,

And so on -ad infivitum."

At right angles on our left was the mosque, of similar shape, but squarer than the palace, and rendered conspicuous from all sides by the addition of a dome, surmounted by a cupola, overlaid with sheets of metal from tin boxes, which flashed forth bravely, "a counter glory to the sun."

Here every morning at six, at which hour he is awakened 
by a blare of long trumpets of most musical tone, the Shehu goes in state to pray, attended by his guard and followed by his court and boy slaves. The same ceremony is daily observed by him at three o'clock in the afternoon and again at sundown.

But to return to our own doings in the precincts of the palace. Arrived at the gate, we were received by the guard who took charge of our horses, while one went in to give warning of our approach. Presently he returned to bid us enter, and, passing under the arch, we came out into a large open court, and then up steps through numerous corridors and rooms, all quite bare of ornament or evidence of occupation, till we eventually found ourselves in another courtyard where, in a kind of recess sat the Shehu himself, surrounded by his court.

$\mathrm{He}$ was engaged at the time putting his seal to various State documents and did not immediately take notice of my presence. This gave me time to observe him. He was an imposing figure, in his richly worked bernouse, bright red silk turban and heavy gold finger-rings; while the stoutness of middle age added not a little to the dignity of his appearance. His rather undefined features, set in a smooth round face, and a kindly expression of eye gave one an idea of weakness, incompatible with his important position. But his appearance did not belie the common report concerning him; it is really only the British protection that placed him, and now keeps him on his throne. Before his reign, on the death of his father, he was carried off and made a slave by Rabeh, and still bears the brands of his servitude on his cheeks. Then Rabeh was finally defeated 
and killed by the French, who freed our friend and made him Sultan of Dikwa, which province he might be ruling over to this day, neither to its advantage nor that of

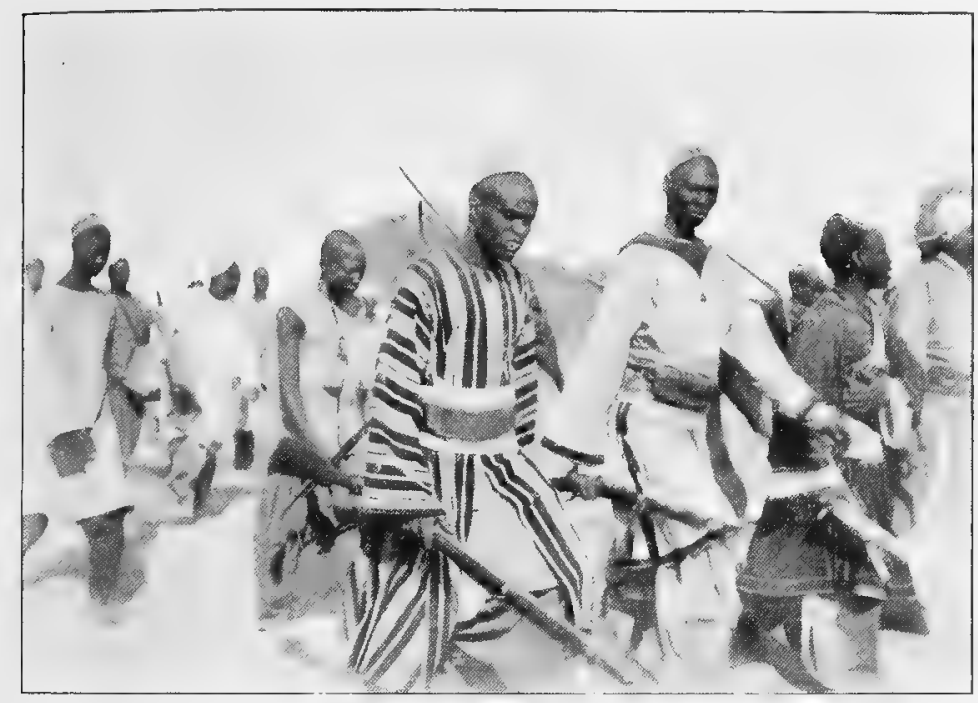

SOME OF THE SHEHU'S ARMY

Bornu, had not Captain McCarthy Morrough by a brilliant coup de main enticed him out of his alien palace one night before the people were aware that any thing irregular was afoot, and brought him on horseback over the border to Maifoni, where he was made Sultan of Bornu. Doubtless his lack of will makes him all the more amenable to our influence, and he may well be considered a good example of his kind, and his rule a good one. I found out afterwards that he was a man of much kindness of heart, and gave many presents of food and money to the poor. It was his custom, on coming out of the palace on his way to pray at the mosque, to hear the cry of any subject 
who was suffering from starvation, sickness, or wrong, and had been fortunate enough to get through the barrier of officials who jealously guarded their master's good heart. He would take the name of the suppliant and tell him to come and speak to him afterwards, when he would help his case to the best of his powers with money, medicine, or advice, or whatever the unfortunate stood in need of. Yet he is not popular with all classes of his subjects; some call his kindness weakness, and the warlike among his chiefs and soldiers compare him unfavourably with his warrior father. Though he may not have a great amount of the wisdom of Solomon, he certainly has his share of that great king's weaknesses, for it was told me that his harem harboured three to four hundred wives. These dwell in the back part of the palace, separated by their own courtyard, where twice a week they are all turned out to march past for inspection and to be counted by their lord. He has two sons by his queen. While on the subject of his domestic arrangements, I am reminded that in his intercourse with me his chief concern was to ascertain if I could impart to him some medicinal charm that would lessen the number of sinecures among the posts in his private household.

Though not exactly commanding in appearance, yet he was at his ease and seemed fully conscious of the dignity of his position. "Sanu! bature" (Hail! white man), he said, and motioned me to be seated. Then passed the usual greetings, and he pointed with evident pride to the sword I had sent him some three weeks before, which now lay before him as an emblem of authority. It was an unmounted blade that I had given him, but handsome, nevertheless, 
made by Wilkinson and originally intended to go out among the presents which the Prince of Wales took for the rajahs

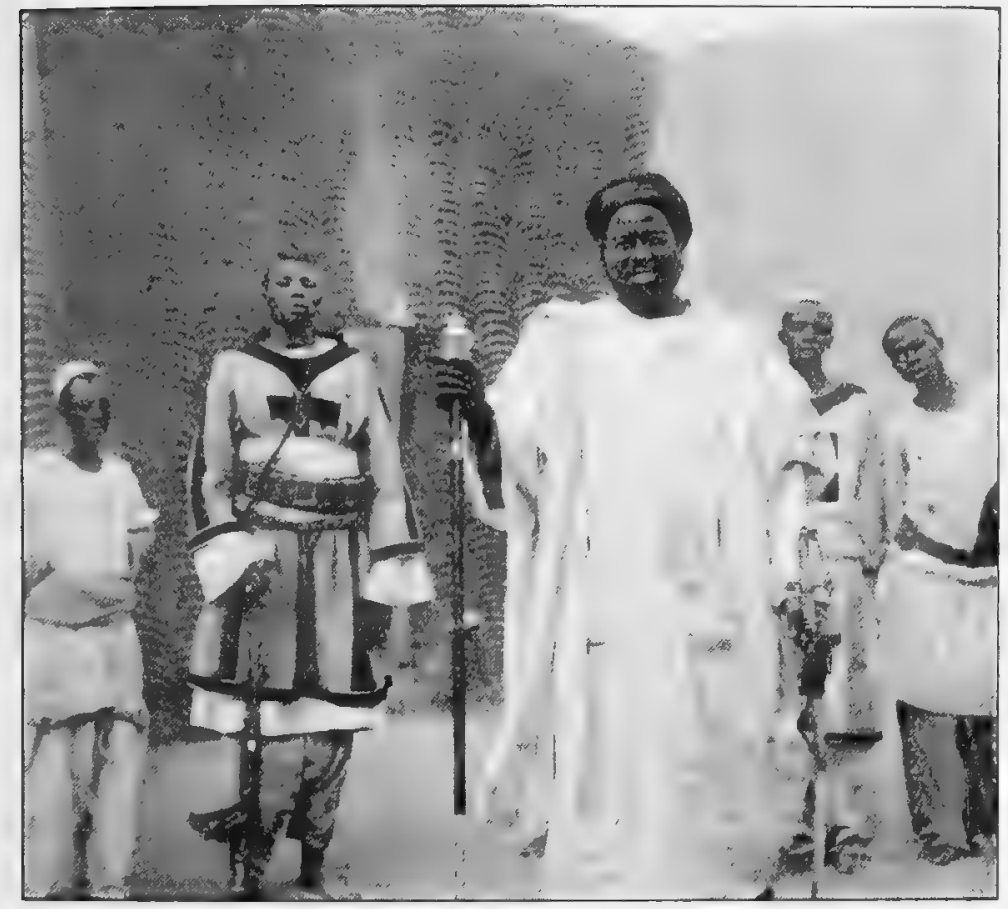

GAROBA, SHEHU OF BORNU

on his recent tour in India. It was now beautifully set in a hilt of worked silver, inscribed in Arabic, and beaten out of Maria Theresa dollars from the Shehu's treasury. This I heard afterwards from José, who was sent back subsequently several times to Kukawa to obtain food when Talbot and I were in camp at Kaddai on Lake C'had. As José talked Hausa fluently, the Shehu made friends with him and let him into his confidence a good deal further than would fall to the lot of the ordinary stranger within his gates, however big a 
personage he might be. He even stretched the ties of friendship so far as to take him into his treasure house, but, with the object of getting him to count up his English money, which the Shehu himself did not understand perfectly. Of this José counted out for him from a bag of coins, ranging from sovereigns to threepenny pieces, forty-eight pounds. The treasury consisted of a totally dark room, fastened with a native wooden lock, and was situated not far from the audience chamber at the end of a long passage where a guard, armed with loaded musket, was posted night and day. While within the treasury, which was lit by a native candle, made of a lump of sheep's grease with a piece of cloth stuck into it for a wick, José had time to observe among other inviting-looking packages twenty bags, about one and half foot long, stuffed with Maria Theresa dollars: there were also two tin boxes, three foot by two in size, full of these coins ; while against the walls stood piles of cloth, a native form of currency less perishable than our bank-notes. I daresay some of my readers will wonder what sort of a coin the Maria Theresa dollar is, that I have alluded to above, and how it comes to be mentioned in connection with the economy of African states, so I will say a little concerning it.

It was originally an Austrian coin of 1820 date, and somehow or other through Tripoli traders came to be the only piece reckoned with by the natives of Africa. So the French have for convenience stuck to it and make it at a cost of about 1.30 fr. each. At Fort Lamy it has a value of 2.50 fr., that is to say, a new one has, but one on which the brooch on the Empress's dress is worn (by time as well as by the lady) the natives will not look at. 
At Kukawa a new one is equal to $3 \mathrm{fr}$., and one with the brooch obliterated, $2.50 \mathrm{fr}$. In Bornu the people are beginning to realise the value of the smaller English money and its greater convenience for buying in the markets.

But now I think it is about time we returned to our friend Garoba. There is not much more to say of his surroundings, either as regards the place or the persons of his court. The latter consisted of his brother, Shef Sunda, who became deputy ruler in his absence; his sheriff, or chamberlain, and some chiefs, and his high priest and several other mallams. These last represented his mind and his will, which with him, as with all other rulers of limited intellect, dwell outside the narrow space of the royal cranium. Then there were close round his person, eight slave boys in attendance.

These were of handsome appearance and beautifully dressed in loose, spotless white smocks, four with yokes of red, and four with green. They carried guns as the Shehu's bodyguard, and whenever he rose from his seat either to go out, or even only to cross the room, one went to the door and called to the guard without, "The king is on his way! The king is on his way!" This was echoed from sentinel to sentinel throughout the palace, and all would stand to attention till he was again seated.

The Shehu's bernouse, to which I have alluded before, was made up in patchwork of various coloured silks. On his feet he wore the royal shoes of brown Bornu leather, striped six-fold with red, a distinction that none of his subjects are permitted to adopt. The couch he sat on was merely a mud block set with a few cushions, and the walls were quite 
bare, save the one behind him, on which I was amused to see hanging the two $\left[6 \frac{3}{4} d\right.$. paper plates ${ }_{L}$ with resplendent portraits of King Edward and Queen Alexandra, which Gosling had given him some little time before.

This reminds me, that in conversation he was very anxious to hear a great deal about the King, asking if he really wore the splendid dress he was depicted in on the plate, or went about, like all other Englishmen, in khaki. On being told "yes" to the first and " no" to the last part of his question, he seemed much relieved.

He also asked how many wives he had, were not all his soldiers black men, and was not his palace very large? Hearing that the King had many palaces, with hundreds of rooms, decorated with ornaments, and soft carpets under foot, he appeared very astonished and said he, himself, would get stuff and carpets from Tripoli.

The complete absence of ornament in his surroundings struck one at first as very strange, for it must be remembered that he is a rich man, ruling over a prosperous country, and owning hundreds of wives and cattle. Moreover, the land is reached by the influence of trade, and Arabs from time immemorial have gone through with rich merchandise from Tripoli, which they barter for ostrich plumes, ivory, and leather, the products of Bornu.

One would have thought that his barbaric imagination would have delighted to visualise his authority in sceptre and throne of some rare wood or ivory, however rudely carved, and give assurance of his wealth, in carpets and rich hangings.

He must have had presents given him from time to time 
that would have taken the shape of ornaments or articles that were designed to be a pleasure to the eye; but, if he possessed any, they were safely stored away, and, as José observed on one of his subsequent visits, even our paper plates had been taken down, and were only hung on the wall to mark special occasions like our own visit. But he shares this peculiarity in common with most natives; headmen would sometimes come to us and buy cloth, and considering it too precious to wear, would lay it up as treasure in the dark, to be taken out and gloated over at rare intervals, and then put back again. It is a child-like instinct which they have to hide away and hoard anything that is precious.

Such a little way back in their history life was so uncertain, and the law of meum et tuum so ill-defined, that any possession of value had to be kept hidden from the spoiler; so that, I suppose, the virtue of a thing came to be enhanced by this necessity, and even in the present time, though there is but little reason for such caution in the preservation of property, the native somehow feels that a mystery is being violated when a cherished treasure is continually exposed to view; so he endows it with a secret virtue, which, like phosphorus, spends itself with too long exposure to the light.

Before leaving, I was anxious to take a photograph of the Shehu, and the accomplishment of my desire brought about a little incident which I will relate.

' I communicated my wish to him through the interpreter and the', instant he understood, his smooth, fat face was wreathed in smiles and his eyes glistened with satisfaction. 
I at once saw that I had got in on his weak spot, his vanity. He was, I believe, just on the point of acquiescing when his mallam, or high priest, intervened, and I could see by the latter's earnest manner and the Shehu's gesture of impatience and disappointment that awkward objections were being raised. These would no doubt be on the grounds of the Holy Law which forbids a Mahomedan having his likeness made.

The discussion soon became general and all the Court joined in with much talk and gesticulation, when a courtier, who perhaps had an eye to the royal favour, or his knife into the spiritual councillor, evidently suggested a compromise, for suddenly the altercation ceased and, two attendants being despatched, the Shehu signified that it was his royal pleasure to permit me to take his portrait. Accordingly, accompanied by me and followed by his Court and guard of boy slaves, he moved out into the sunlight and took up a pose, holding on to a smile with a determination that would have done credit to a professional beauty. Then came a most unexpected interruption. Just as I was pressing the button that would record the Shehu's smile and Allah's frown, my attention was arrested by a stir in the gateway across the courtyard on the left, and the eyes of all save the Shehu, who was motionless, were directed thither.

There we saw two powerful men, semi-nude, bearing in a heavy load, which, on their emerging into the sunlight of the yard, proved to be a fine, big sheep. Instantly the thought flashed through my mind that here was_a royal gift for us; so, too, thought Talbot, who was standing just behind me. 


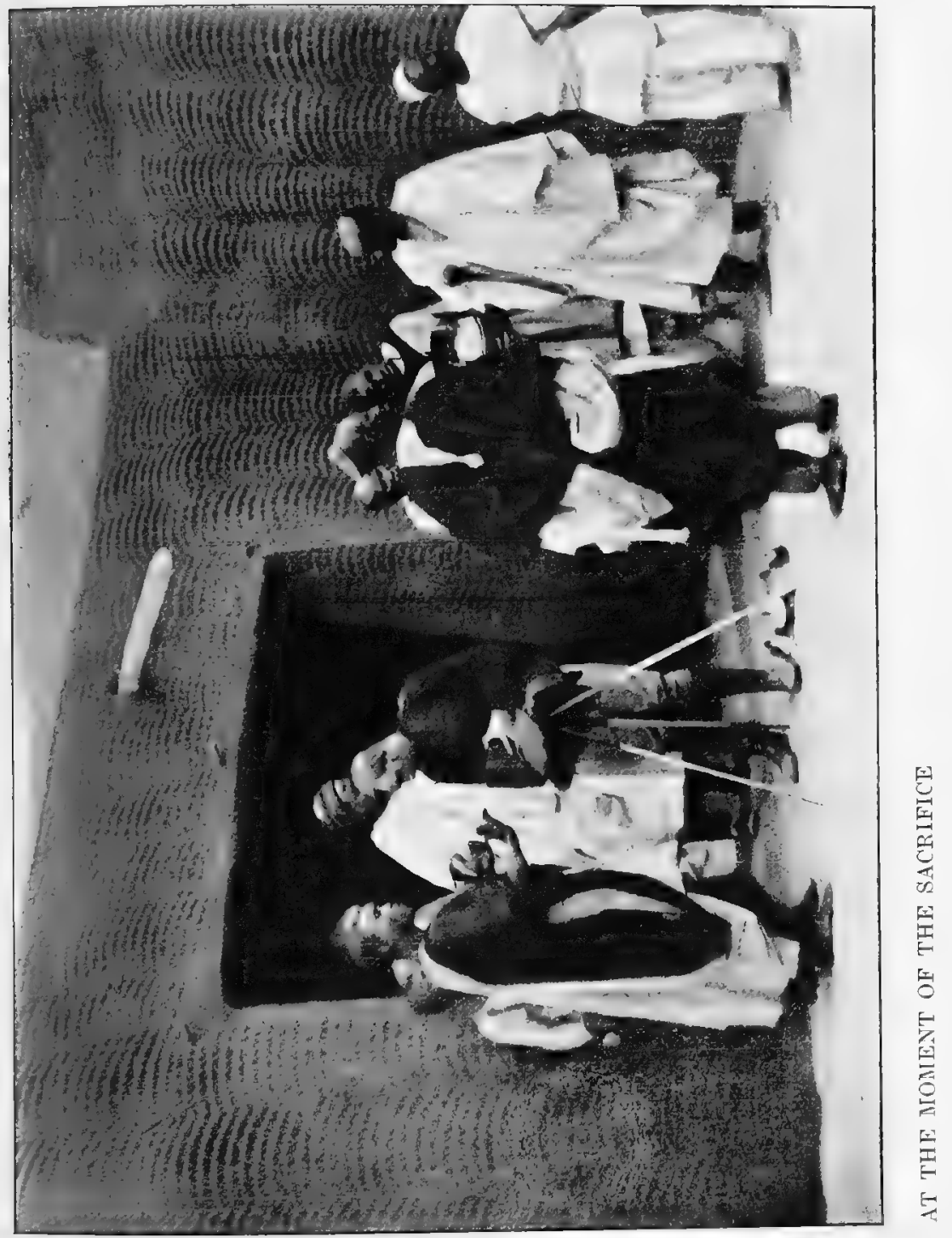



But our hopes, and not our services as photographers "By Royal Appointment," were destined to be "dashed" on this occasion; for behind the fine group of the bearers and their load came a mallam with naked knife, which he drew with dexterous sweep across the throat of the animal the instant it was thrown to the ground. Thus the diversion was explained and the wise courtier's policy revealed. Surely Allah was appeased by so rich a sacrifice, and the evil-eye of the camera averted! 


\title{
CHAPTER XV
}

\author{
FROM KUKAWA TO KADDAI
}

But the distraction caused by the unexpected incident of the sacrifice did not make me forget the business in hand, and I managed to secure my picture of the Shehu. I then turned my camera on the sacrificial group, but unfortunately no record has appeared upon the plate. At this point an attendant came in with a message to the Shehu and this gave us a good opportunity to say our farewells.

In the afternoon he sent his headman to our camp to buy cloth. He had heard of its excellence; in fact, our fame as clothiers had spread far, and merchants even came from Fort Lamy, which is ten days' journey from Kukawa, to become possessed of our wares. Altogether we did a very brisk trade; many of the big men of the town were also our patrons and French cambric, costing us originally $5 \frac{1}{2} d$., changed hands at $1 s .4 d$. per yard! I heard afterwards that the Shehu, who was a large buyer, used his purchase for making into jackets as presents to his chiefs at the time of the great Mahomedan festival of Ramadam.

These people showed very businesslike methods in their selections and tested the quality of the various goods with critical finger and thumb. The way of measuring was to hold the cloth from mouth to finger-tips at arm's length, and they would very quickly object if one employed the service of a 
boy whom they did not consider full-grown. They generally took out the amount of their purchase in lengths of four yards, which is called "a cover," derived from the measure considered sufficient to drape a woman becomingly. It is amusing to see them afterwards unrolling and discussing their bargains with their friends and attendants. When they have inspected and talked them over sufficiently, they hand the purchases to their slaves, who fold and wrap them up in a covering of native cloth with great care. Then they take their departure, with their slaves carrying the parcels behind them.

We were very pleased with the success of our sales in Kukawa, as after this point in our journey there was no longer the necessity to carry so much trade goods; the journey in the future was to be for the most part by water, so that we were able to lessen the number of our carriers and with them, consequently, the need of buying large supplies of food from the native villages we came across, which always had to be paid for in kind.

There was a time in the history of Bornu when the people would have bid more keenly for weapons of war, and rotten pistols and brittle sword-blades would have found a readier sale than bales of cloth. But now the people realise that they have fallen on times of peace, and the big man who formerly went to war and displayed his power in a show of arms, has now turned husbandman with horses, flocks, and herds, which have made him a man of wealth and importance that he loves to show in a display of rich and abundant clothes.

Next day we resumed our journey; this time with a very much smaller column, for we had sent back on our arrival 
at Kukawa the sixteen oxen which we had collected at Maifoni. These had been obtained for us by a chief in the usual way; that is, one summons a chief of the district and tells him to supply a certain number of oxen. Thereupon he sends word round the headmen of his villages, telling them to send in, each a proportion of the number required. The oxen come in, attended by their owners, and it may happen that one man supplies two beasts. The men accompany the transport for the journey, are paid off at its end, and return home with their oxen. The chief takes a proportion of their earnings, and in some instances, if he is a rascal, he commandeers, in the name of the white man, perhaps double the number of oxen asked for, and when his people, badly in need of the services of their beasts for carrying their produce to the markets, have not enough to meet both demands, and offer to pay a fine-generally about three shillings per head-he accepts the alternative and pockets the fruits of his fraudulent misrepresentations.

At Kukawa we paid these men seven yards of calico each, with which they seemed very pleased and took themselves off to the market at once to buy what they needed for their return journey.

¿Our camp here, or rather, sleeping-ground, for we had not slept under canvas since leaving Maifoni, from which place our tents had been sent with Gosling's column to Yo, was situated under a large acacia-tree close to the market. The weather had been glorious and no tents were necessary, and privacy was obtained for our open dwelling by a screen of zana matting, which the Shehu had caused to be put up for us. This was well, for we were quite close to the market and 


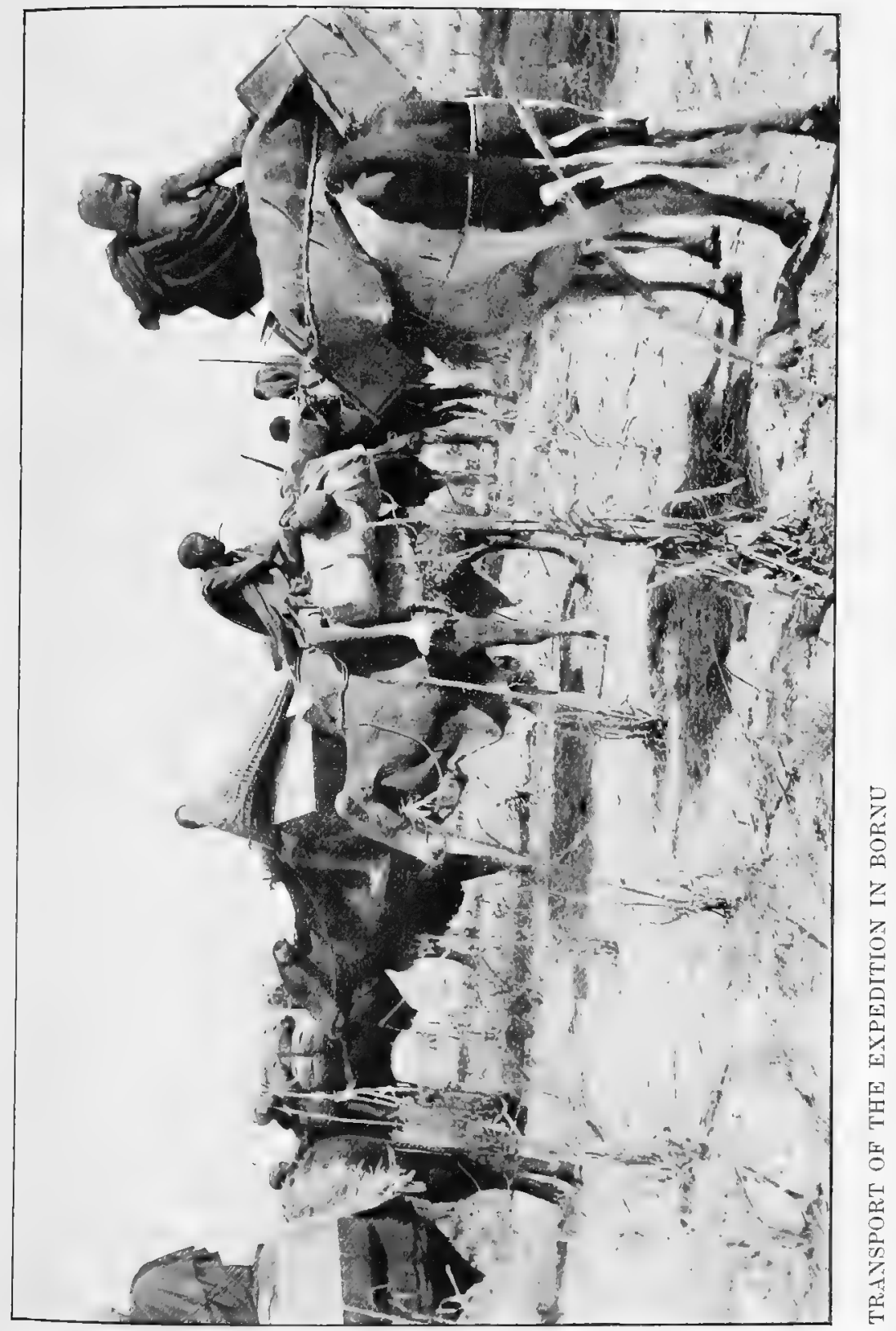


$$
\text { - }
$$ 
in the middle of the town; a convenience for getting supplies easily, but a nuisance in other ways, for the "boys"

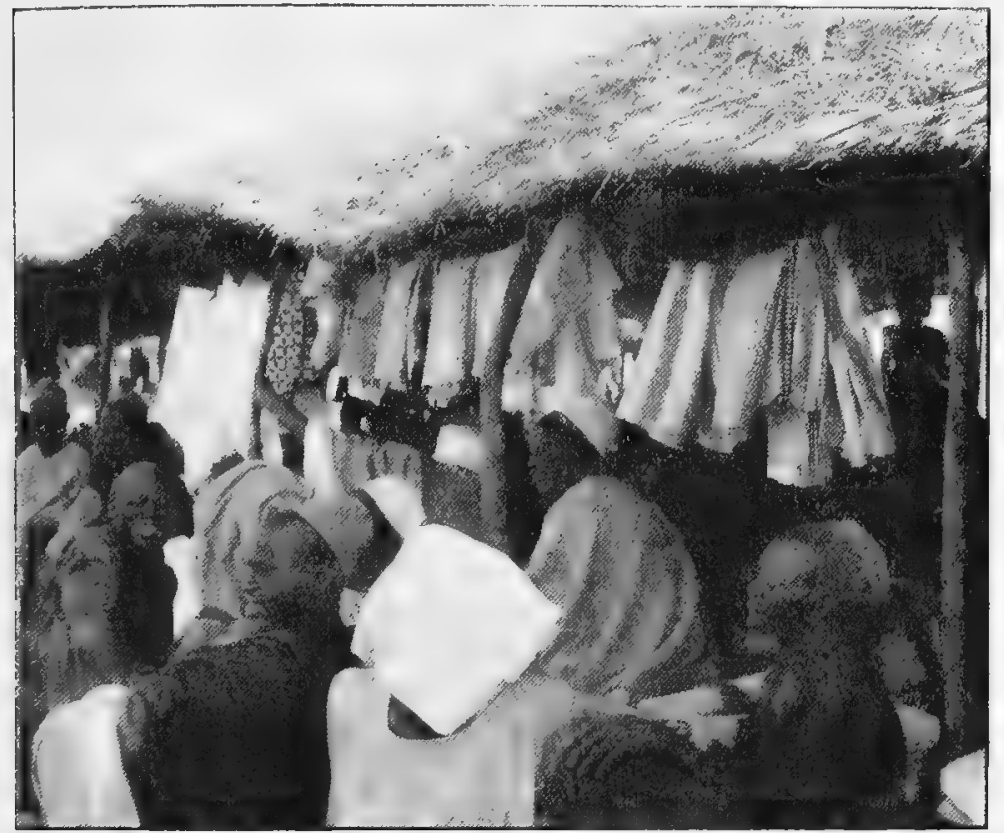

CLOTH STALL IN KUKAWA MARKET

who look forward on a long trek to the village market at its end as to an eldorado, were never to be found at home under the tree when wanted. Of course they were in the market! The young rascals know the white master's considerateness so well, that they always offer an excuse that would be very plausible if only it were not made far too many times in a day.

Our last night at Kukawa was more than usually beautiful ; warm, still and clear, and the sky was spread with all the wealth of the stars. Such a night as would uplift the heart of any man, let alone an astronomer. Talbot being one, was 
literally in heaven and with the sextant obtained some good observations.

But the world got out of the wrong side of her bed the next morning. I never saw such a contrast. The memory of the serene night of peace and beauty, shut off by only a few hours of sleep, was with us when we awakened to the sight of a desolate, dust-coloured world; unpeopled, for the natives are crouching inside their huts, while without, town, trees and hills, all are smudged in one grey blur. How eyes smart and lips crack! Little wonder! when the boots are doing the same. Even the books are getting their backs up, and the lids of the wooden boxes show a decided hump. It is the harmattan that is causing all this upset; the northeast wind that prevails here from November to March. This was our first taste of it and we had our mouthful that morning ! Our porridge and eggs were full of grit, and the fresh-cut slices of bread became hard like toast in less than half an hour, and we were as cold in our bones as on a bleak November day in England. It was "speeding the parting guest " with a vengeance, and we were glad to be up and on the move again.

So we took the road to Kowa which was to be our next halting-place. Four oxen, lent by the Shehu, the carriers with their loads, and the escort went half an hour ahead of us; then came Quasso in charge of the "chop" box, and Talbot and I, attended by Adamu, the guide, followed at our leisure. Not a soul was abroad in the town, save the soldiers on guard at the palace gates which we passed on our way; they wore an aspect in keeping with the bleakness of the morning; silent and sullen, with the hoods of their 
bernouses drawn up over their heads. Ten minutes at a walking pace brought us out of Kukawa, into country

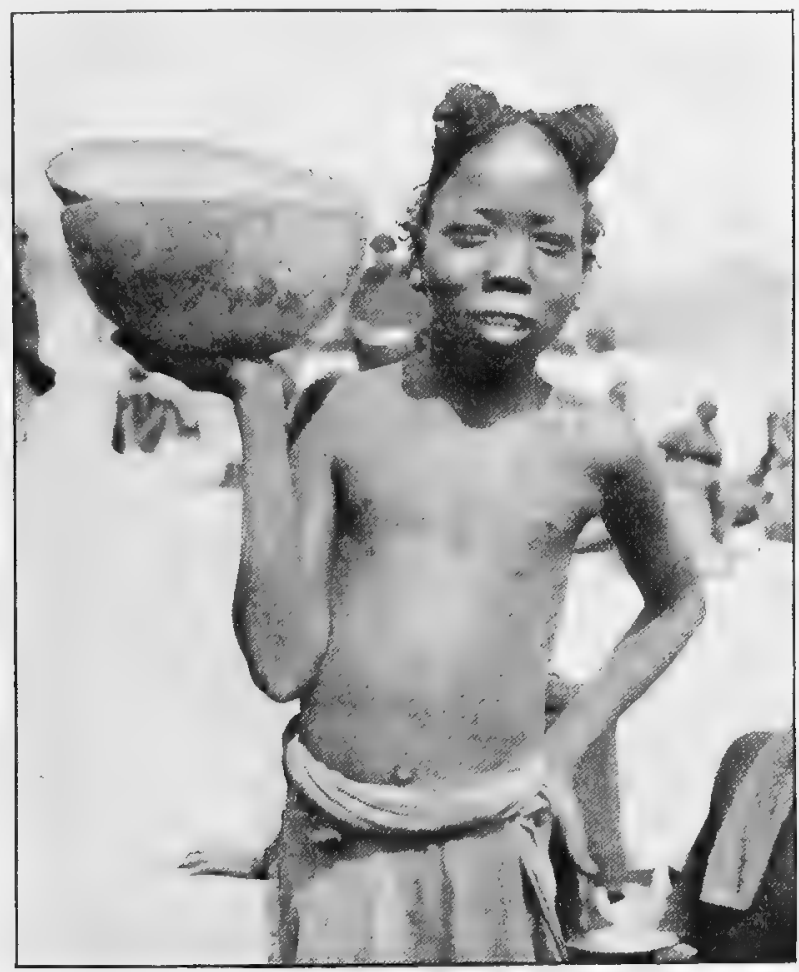

A KANURI GIRL

similar to that already described on our road from Maifoni; only that now there was little of it to be seen through the thick sand haze. Now and then on the way we would meet a party of donkeys and their drivers, that would loom up suddenly a hundred yards ahead, pass, and disappear as suddenly in the mist of sand behind.

We arrived at Kowa in time for mid-day "chop," and were met on our entrance by the chief mallam. The king, 
or lowan as he is called, was away at the time, but had made arrangements for our reception by the order of the Shehu. Here we found square shelters of zana matting put up for our use in one of the open places of the town, and a large " dash" of ground millet for the men, and eggs and fowls for ourselves. The tea that accompanied our "chop" never went down more deliciously, for our tongues and throats were by now as rough as sand-paper.

At about three o'clock in the afternoon the harmattan drops as suddenly as it springs, and on this day, to our great relief, it made no exception. The atmosphere gradually cleared and at six the sun went down in a fiery, crimson glory, which shot along the horizon, sending a flush far up into the sky that paled to gold, and higher faded into green. These wonderful sunsets are a characteristic accompaniment of the harmattan, caused by the myriads of dust particles in the air.

Kowa is a large village, or I suppose we ought to dignify it with the name of town, since it has an important market just outside on the road to Kukawa.

Here the principal trade is done in potash and dried fish, which are brought up by Kanembus from the Buduma fishmarket, some fourteen miles distant on Lake Chad. The latter place is called by the Budumas Kowa Baga, which means the market for Kowa. Besides the market, there are dyeing pits and also a place for curing skins and leather making.

Kowa is the capital of an important district governed by the Lowan, a by no means insignificant chief, ruling over the Kanembus and Budumas, who are loyal to him, for he treats them well. 


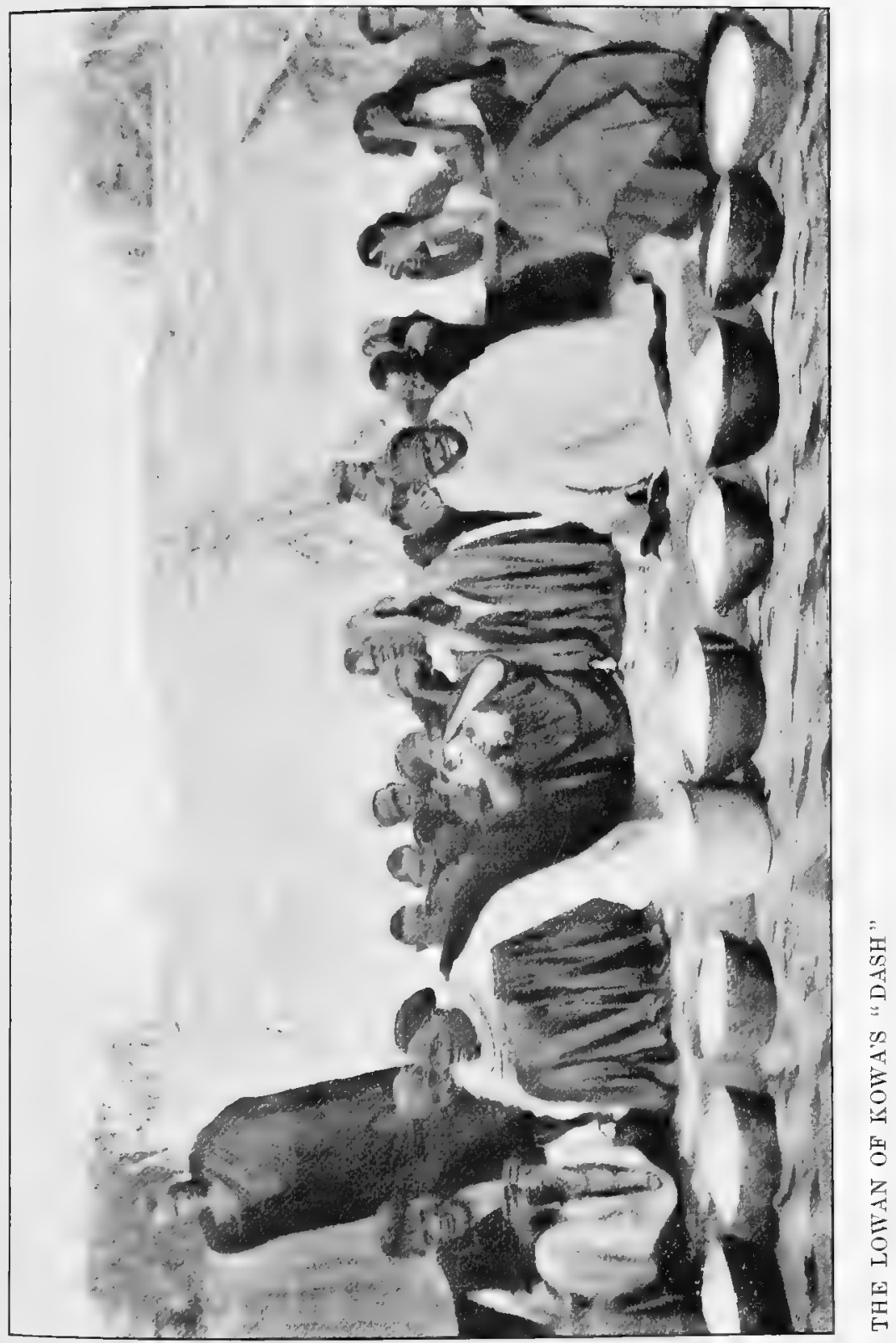



The Lowan is a harsh-featured man, tall and very broad, of simple tastes and, though rich, making no display. Secretly

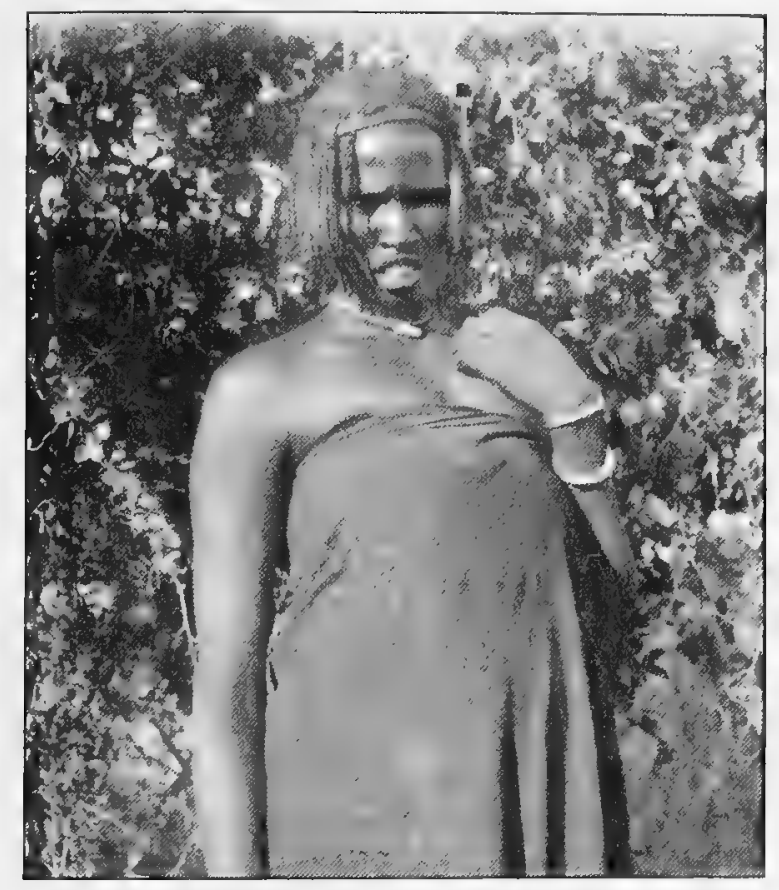

A KANEMBU WOMAN

he is not very friendly to the white man, and there is not much love lost between him and the Shehu of Kukawa, whom he would fight to-morrow if it were not for our occupation and, doubtless, if he did have his way and came to blows, the Shehu would stand a poor chance, for the Kanembus and their allies are a finer fighting race than the Kanuri and Shua tribes. The Kanembus, who are the people now inhabiting the Kowa district, came from Kanem, the land east of Lake Chad, whence they were driven westward by the Arab razzias, or slave traders, from Wadai. 
From inquiries among the natives and my own observations, I am sure that the Budumas also hailed from Kanem and took refuge on the islands of the Lake. The two peoples are very similar in type, more especially the women; this is natural, for throughout the native races the conditions under which the women live are so much the same, whereas the men take on the characteristics of their callings to a certain extent. Thus the Kanembus are pastoral and keen hunters of game and in build are suited to their pursuits, being strong and lithe; whereas the Budumas, who are fisherfolk, spending most of their time in their canoes, are very much bigger and heavier than the Kanembus, but of remarkable strength derived from the heavy work of poling.

But more of the Budumas when we reach Lake Chad, and now to return to the Kanembus. They are a fine race and prosper as hunters, farmers and traders; they grow large crops of millet, some of which they trade in with the Budumas for fish and potash. Potash is the great monopoly of Kowa and upon this the Lowan waxes rich, for all the supply goes first through the Kowa market and has to pay a toll. Though it is not worked, potash must also abound in this part of Bornu, for the water in all the wells is very strongly impregnated with it, and we found it rather pleasant and wholesome to drink. As black-water fever is not known in this part of the country, I have sometimes wondered if the immunity from this terrible sickness is not due in a great measure to the beneficial effect of this mineral, for salt is now largely used with good results in the treatment of the disease.

Since the Lowan gains so much by the potash industry, he 


\section{FROM KUKAWA TO KADDAI}

studies the Budumas who produce it and makes large presents to the island headmen of clothes. These are the dark-blue

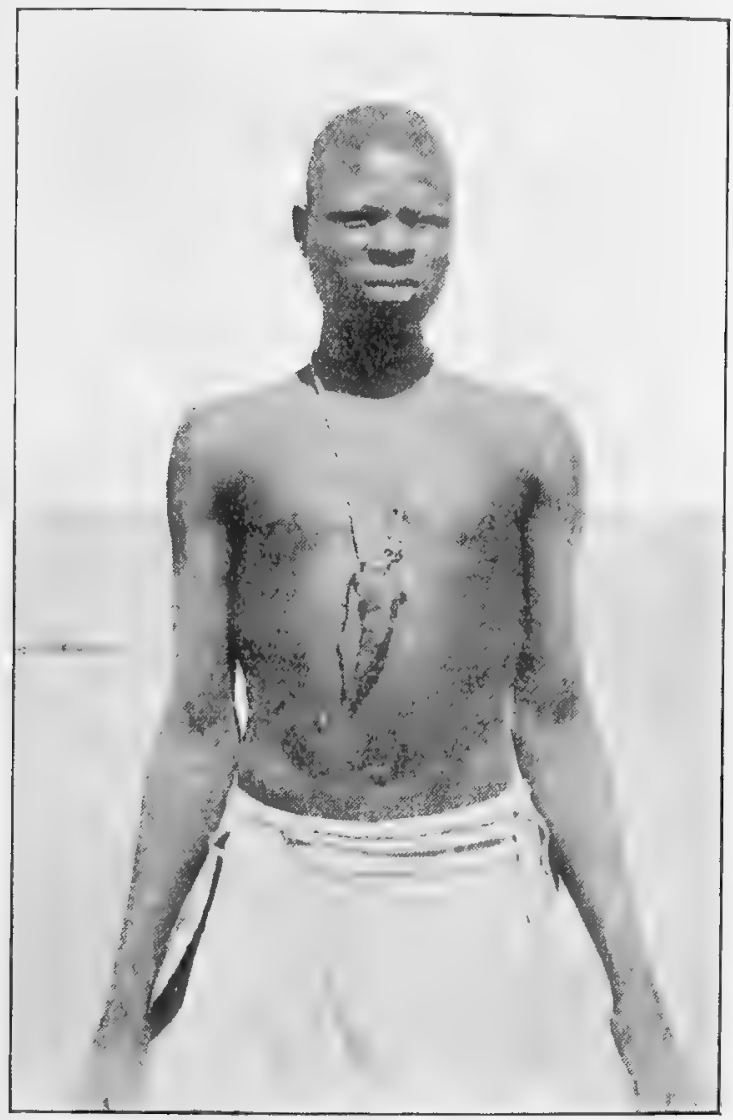

A KANEMBU BOY

bernouses, dyed from the juice of a small-leaved, creeping plant that grows very locally on the shores of the Lake. The leaves are collected by the Lowan's slaves, who are of the Baghirmi tribe and originally the soldier's of Rabeh. Many of the Kanembusalso remember unwilling service under that chief and bear his mark, two vertical cuts on either cheek. This 
branding with Rabeh's sign, so frequently found throughout Bornu, is on the same lines as tribal marks which distinguish the people of one tribe from another, only Rabeh's mark denoted that all tribes were one in his eyes, that is to say, his subjects by right of conquest.

The tribal mark of the Kanembus is three vertical cuts on each cheek and seven on the forehead, the middle one extending down to the bridge of the nose. Tribal marks were originally intended as a means of identification when slave-raids were common and women and children in danger of being kidnapped by robber bands, just as we brand cattle that we may the more easily recover them from a neighbour's herd into which they have strayed. But now there is little significance attached to them, though habit has created a fashion out of them, and in the eyes of a tribesman the face of a woman is expressionless without them. To-day one finds many women with additional marks self-imposed. I remember being puzzled the first time I saw a woman thus altered, and when I asked why she was different in this respect from the rest of her people, she answered that she wished to be more beautiful. The Kanembu women are particularly friendly, always greeting the traveller with smiles and a "Lalli lalli, wissi wissi," which means, "How are you, I hope you are well."

Though the Kanembus are now able to live in peace and pursue their pastoral calling for the most part unmolested, they are not yet altogether "out of the wood"; in a very literal sense, for, when in the dry season they drive their herds down to the Lake, they take them through thick bush all the way to screen themselves and avoid the open ground 


\section{FROM KUKAWA TO KADDAI}

along the shore, until they get oplusite to the wateringplace. This they do for fear of the Tubus, the robber tribes

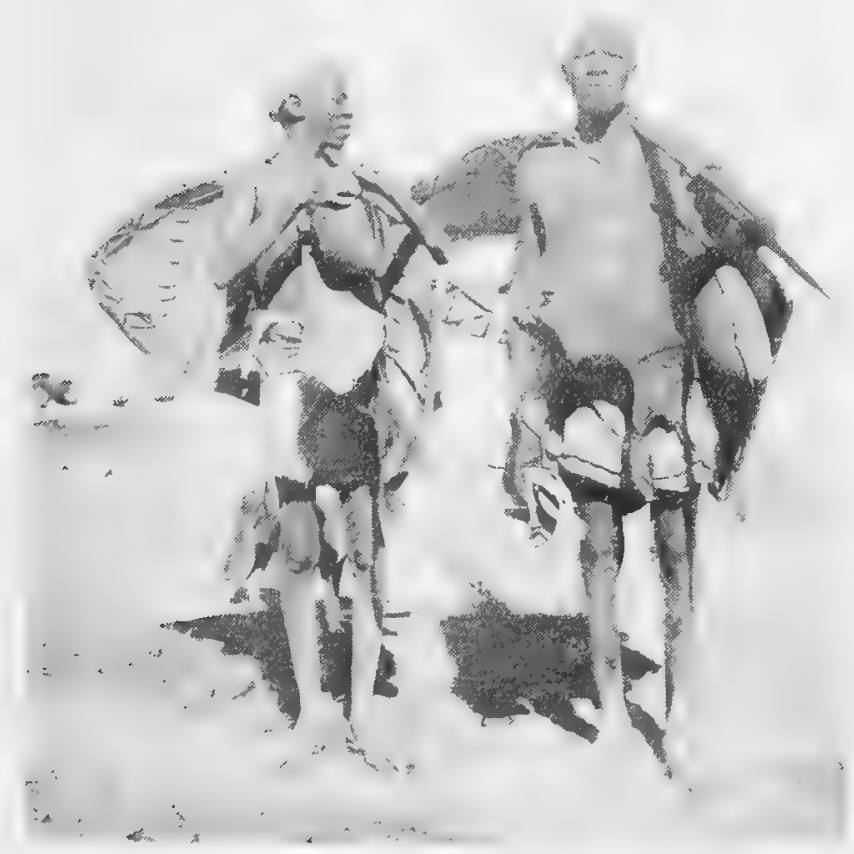

K.INEMIBU S:TEPHERDS

of the Sahara, who live by raiding and slave-truling. Theste ruffians are very daring at times. While we were at Kaddai a party of them carried of three girls and a boy from the neighbourhood of Kowa itself. But they were promptly pursuerl by the Iowan's horsemen and their victims recovered.

Game in the country is fairly plentiful and various. Elephants, lions, hartebeest, kub, and gazelle are to be 
found. The Kanembu hunter turns his attention chiefly to the three last named, for which he employs traps as a general rule. The most usual is made as follows: a ring of wood with spikes upsloping towards the centre is placed on the ground, then a noose, to which is attached a log of wood, is laid over it. The beast puts its foot through the ring, drawing the noose from the inclined spikes to a position well up the legs, where, tightened by the drag of the block, it gets taut and cannot slip down; the frightened beast thus hampered, runs until brought to bay with a dog, or else gets hung up in the bush, and is then despatched with a poisoned arrow, if necessary.

In another method nets are placed on each side of a track that runs down to a drinking-pool frequented by the animals, whose retreat is then cut off by the closing together of the ends.

The ostrich, which is found in small numbers, is not much hunted because it is so very difficult to get near. The natives, instead, catch the young ones, which become domesticated, and one finds most of the big men in Bornu owning three or four.

We stayed only one night in Kowa, and after our usual breakfast of porridge, eggs and milk at six next morning we mounted our horses, and, accompanied by a guide whom the mallam furnished, started for Kaddai. Our journey was now in an easterly direction through wooded country for about two miles, and afterwards by sheep-tracks through miles and miles of maio bush (euphorbia). This plant grows to a height of about $5 \mathrm{ft}$. and has opaque bluegrey leaves and pods the size of large pears, which burst 
as we brushed through the thickets, splashing us and our horses with a sticky white juice rather like rubber. The dull-coloured green of these bushes all around and ahead, never relieved by any other foliage, became very monotonous and the effect was intensified by the grey misty weather that the harmattan had again brought with it. When the bush began to open out and give way to more open country, we were in great hopes of getting a view of the Lake, for we had come a distance of fourteen miles and by now should have reached it. As a matter of fact so we had, the guide informed us, but our view was shut out by belts of maria, billowing in form, of a beautiful tender green and so compact, that they gave rather the appearance of topiary work. Here and there one saw a hole in the undulations caused by elephants rolling. These animals often spend the whole day in the maria belts and keep themselves cool by standing in the water and squirting it over their backs; then at night they retire inland to get away from the clouds of mosquitoes. The belts of maria thorn were growing in a foot of water, so were actually in the Lake.

We now had our "chop," for which we were quite ready, for it was past two o'clock and we had been in the saddle since seven. Moreover, we were bored by the monotony of the road, and nothing I think makes one so hungry as being bored. So a fowl and some sweet potatoes, cooked by Lowi the night before, furnished us with congenial occupation.

But I must not be so ungrateful as to forget that just before, some Kanembu goatherds did their best to afford us a little diversion by acting as if we were Tubu robbers. 
On catching sight of us, they rushed down to the marshy ground where their herds were watering, snatched up their spears and gourds and drove their goats into the bush to the accompaniment of a good deal of shouting. At this point we thought that they had done enough for our entertainment, so sent our guide after them to tell them who we were.

After "chop" the guide took his pay in cloth and bade us farewell. The wind now dropped and the mist, which had been for some time furling itself up in layers of little clouds, was dispersed by a hot sun, whose rays we did our best to combat with bushes that we cut down to make a screen; but with small success, for the leaf was not thick enough to give much shelter. We therefore, tried to forget our discomfort in activity, and Talbot went off to look for hartebeest, while I turned my attention to the investigation of the bird-life of the locality, with one eye open to collect evidences that the Lake in these parts was not merely phantasmagoria in the brain of our erstwhile guide. I made several incursions into the maria thorn, tearing my clothes on the spikes as I waded knee-deep in the water. Each time I paused to listen, the stillness was gently parted by the liquid piping of the reed, and the shrill shivering little note of the sedge-warbler. How magically their voices carried me back in spirit to the osier beds at Rye, and for a while my thoughts forgot to follow my footsteps and threaded long vistas of dear memories opening at their calls. So, perhaps it is not to be wondered at that, following those sounds on so far a journey, I did not see a single bird; yet I felt content to have heard their very friendly little voices. 
I now bethought me to turn water-finder on a large scale, and accordingly set out in search of Lake Chad. After plunging about for some time, at the cost of more rending of garments I at length got through the belt of thorn and reeds, when, Eureka! there was a sheet of open water, fully ten yards across to another belt on the farther side. My approach disturbed quite a number of plover and waterfowl taking their pastime therein as though it were the only lake within miles. Perhaps it was, yet I returned to camp, strangely contented with the little I had seen and heard.

Not so Talbot, who came in soon afterwards having hunted all the afternoon and killed nothing. Our exertions, however, had induced appetites that fortunately could be satisfied and, though no spoil of the chase graced the board, we were not reluctant to sit down to an early evening meal, which consisted of soup, fish cakes made of sweet potatoes pounded up with fish powder, and chicken cutlets in bread crumbs_or "cutlegs" as the "boys" used to call them in their best attempts to master the intricate terms of the menu. These were pleasant evenings by the lakeside, beneath the wondrous depth of the blue, starlit vault, with lazy conversation and still lazier thought, that seemed almost to have voice in the profound stillness of the night. I call "fire!" and Quasso noiselessly brings a burning stick to light my pipe. And while my thoughts dissolve into the airy stuff of dreams as I watch the glow of my pipe come and go, Talbot, who never smokes, looks up to find his friends among the stars. There were the soft-veiled Pleiades and red Aldabran climbing to the meridian, and low in the South hung the Southern Cross that marks the 
crest of the World. To disturb the silence, only one noise came at intervals, growing ever more frequent-the sharp sound of the "boys" round the camp fire a little way off slapping mosquitoes that tormented their bare flesh. Nor did we need to be reminded that we ourselves were not left unmolested by these pests, and an early hour found us seeking shelter in bed beneath mosquito nets.

The night was cold and the "boys" passed a wretched time, complaining bitterly, for there was not enough wood to keep the fire going, and they slept without shelter on the bare ground. With a good fire to go to bed by they are perfectly content and do not trouble about much else. They will keep one going all night long, taking turns to feed it, and they sleep sitting or lying almost in the embers, turning first one side, then the other to the blaze. Sometimes they roll into it and get their clothes, if not their skins badly burnt. Apart from the comfort of its warmth, the sense of security from beasts of prey that a fire gives holds them constant to the habit. They will even keep a fire alight in the pouring rain and prefer its company under these uncomfortable conditions to the shelter of a hut. I remember once afterwards in camp at Kaddai, when they were ordered for their health's sake into the huts from a perfect deluge, they managed to keep a $\log$ smouldering under some branches, and no sooner was the rain over than they were outside again with a good fire lighted, round which they finished their sleep on the soaking ground.

Next morning we were up and away early. Talbot took a curve inland through the bush to look for game, while I continued the journey along the lakeside. The maria now 
assumed a finer growth. It is a slender tree with small leaves of a very dark green; it attains a height of $30 \mathrm{ft}$. and the wood is strong, but of extraordinary lightness;

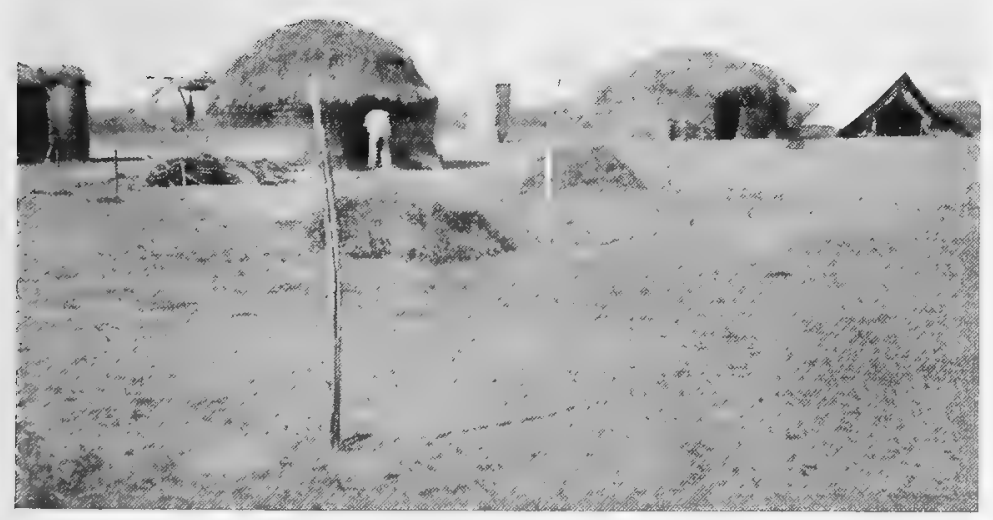

THE CAMP AT KADDAI

the combined qualities render it extremely useful for boatpoles, and the Budumas take advantage of its cork-like lightness to float their nets with.

At eleven o'clock a messenger came from Talbot to say that he had killed a hartebeest and wanted help to bring it in. As usual, such an event created great excitement among the "boys." Since we should now be delayed some time, I decided to pitch camp, and Dumbornu went out to collect wood for the fire from a mass of maria bush which had been broken down by elephants. Presently he returned to fetch help to carry the wood in. The first man who saw 
the huge pile that Dumbornu had collected into a faggot refused, saying that it would break his back; but with persuasion and pretence of help he was induced to give a heave at it, when it flew up like a bundle of feathers. The same joke was played on some of the others till the whole camp was in roars of laughter.

I employed the afternoon while waiting for Talbot in making another incursion into the bush that lined the Lake in search of the warblers I had heard the day before. I was not long in finding them and obtained some good specimens, which were the first birds of my Lake Chad collection. I waded out some distance in their pursuit, and once or twice again came upon small pieces of open water in the form of little coves that gave promise of my presently coming within open view of the Lake; but my prospect was always barred by island-belts of bush beyond. These little pools were full of waterfowl, and for the first time I saw herons in large numbers.

I returned to camptowards evening, to find that Talbot had come in. Soon a fire was lighted and the hartebeest got into a condition ready to contribute variation to the evening meal. This passed as pleasantly as upon the previous evening, and the maria bush cheered us with the comfort of a merry blaze, but, alas ! this did not last long, for the lightness of the wood made it burn extremely fast, and our supply was soon exhausted.

Next day we started early to cover the last distance that would bring us to our camp at Kaddai. The journey was not marked by any fresh event; Talbot rode on ahead, in order to make preparations for our arrival, while I followed slowly, 


\section{FROM KUKAWA TO KADDAI}

on the look-out for birds. The character of the landscape along the route underwent no change; always the way led along the broad, open stretch of grass and sand that lay between the belts of bush upon the land and the dense maria thickets fringing the hidden Lake. No signs of life were met with save tawny owls which at our passing woke out of their sleep in the grass and flew silently away like unhappy spirits that have been rudely summoned before their appointed hour.

Farther on the maria gave way and, growing less and less, presently disappeared altogether. Then we came within open view of the Lake. The great expanse of water, stretching as far as the eye could reach and only broken by a few distant islands blurred to phantoms by the mirage, assailed the senses with a thrill of joy, as a vision of beauty which, long guarded from the gaze, had suddenly yielded and let fall the veil. 


\section{CHAPTER XVI}

\section{OUR FIRST VOYAGE ON LAKE CHAD}

I RODE into camp at Kaddai about eleven o'clock. The four huts which the Shehu had caused to be built for us upon sites that I had previously selected were placed about 900 yards from the Lake, to allow for the rise of the water when the wind set in from the east; for, owing to the shallow nature of the Lake and the level lie of the land, an ordinary wind brought the water up 500 yards over the shore, which all along the western side slopes so gently into the water that there are no containing banks.

I had selected this as a convenient site for our camp, because there was a Buduma fish baga, or market, that did trade with Kukawa and was connected with that place by a rough bush path. My idea was that by living alongside of these shy lake-dwellers we might gradually gain their confidence and so be able to gather information and perhaps enlist the services of a guide to help us in our exploration of the Lake. But, to my great disappointment I now found on my return that the Budumas had decamped, not on account of the white man's coming, but for fear of the soldiers and carriers, whom all natives distrust and detest,-especially the soldiers, who are a difficult problem to deal with in our colonies, for as soon as the white man's back is turned the native soldier, if he can possibly get a 
chance, uses the show of authority that his uniform and arms give him to plunder and ill-treat the defenceless natives. Of course, this does a tremendous lot of harm to the white man's rule. While I was at Lokoja there was a case of a Yoruba soldier who deserted from the garrison, taking with him a copy of the King's regulations. With this he went about all over the country, on the strength of it "squeezing" the chiefs for cattle and sheep and anything that he had a fancy for, and it was a long time before his depredations were discovered and he himself caught. Once I had to punish one of our escort for snatching cloth away from a woman on the road almost under my very eyes. Nor was this the only case of abuse that came to light.

We found only one of the steel boats at Kaddai, for José had not yet returned with the other from Yo where he had gone to fetch the rest of the stores. Gosling, also, was at Yo making a collection of fish. He experienced some difficulty in catching specimens small enough to go into the spirit tanks, as the Buduma nets are large in the mesh. However, his efforts were most successful, and out of twenty-four different kinds that are known to the natives by name he managed to secure twenty-one. This reminds me that Gosling had a most thorough system of ascertaining from the natives the names of animals, and their habits and likely localities. So he was able without waste of time to find out exactly what was worth hunting for in each part of the country he came to.

As the survey of Nigeria was finished, it was decided that Talbot should return to England with the material collected for embodiment in a map; but he was naturally anxious to 
see as much as possible of the Lake before leaving, so we determined to lose no time, and employ the days while waiting for Gosling and the other boat in making a voyage. Accordingly, next morning, December 8, we made ready for a start, provisioning ourselves for a five days' trip, and taking with us Quasso and Lowi and the crew of six Nupe polers. And I must not forget a so-called kinsman of Adamu, whom the latter recommended us to take as having experience of the Lake and the Budumas. When we went down to the water's edge, we found it had gone back 200 yards in the night owing to the dropping of the wind, and had left the boat high and dry. So our start was delayed for some little time, and a good deal of hard work had to be done, dragging the boat across the mud to float her again.

But before we start on this our first voyage on the Lake, perhaps it would be as well to make a few general observations about the geographical features and the impression they made upon me the first time I beheld them. For, I am sure that some of my readers, still regarding Chad as a mythical sort of region, will have pictured it in their minds, as I once did, as a bright-blue inland sea, with fine, steep banks clothed in luxuriant trees; with islands of tropical palms reflected in clear pools of amazing depth that in places glisten bright under the hot, blue sky and in others are dark with the shade of high, adjacent hills. Their imagination will have painted smooth, shell-strewn shores that curve round sheltered bays, into which open wide-mouthed rivers that have wandered through the wilderness to this fair water Canaan, forgetful of their fountains in far distant hills. Here they have thought to find the grateful earth girdling 
the Lake with a belt of forest green that extends an open sanctuary to birds and beasts and men, fleeing from the pursuing hunger and thirst of the great, tawny desert beyond. But, instead, to view the real Lake Chad, Fancy must go clad in sober grey and with earth upon her head, and she must not fear to take her way alone, for there is desert of water as well as of sand. Imagine a large pool in a grassgrown plain, lying shallow like water in the palm of an outstretched hand, formed by the rivulets of the rain coming to rest in the gentle depression of an otherwise flat surface, and you have a miniature Lake Chad! That is to say, you will have some idea of its formation, but the image rather tends to destroy a certain grandeur which it possesses, a solemnity which must ever belong to the great open places of the world where earth and sky can meet and the elements have space enough to show the splendour of their gigantic forms. And if Chad is never a glad pageant of blue and green and gold, it is often a tender vision of grey and silver, the harmony in which the spirit of loneliness abides. For, loneliness is the spirit which haunts the Lake, and the traveller will soon or late come under her spell, if for long he follow her ways-ways that lead him from rosy dawns over grey waters to sunsets of fire and emerald, past the straits of numberless, silent islands for days and days, yet ever barring his entrance into complete knowledge of herself with impassable mud-shallows and bands of reed and thorn.

There is a very mystery brooding over the place, that seems to have thrown an enchantment on its waters and peopled its islands with spirits from the shadow world. 
For in a single night, and without the reinforcements of the rain, the Lake will march up at the call of the east wind and subdue the land for half a mile, or, in a few hours sink so fast that numbers of great fish are left stranded. Nor can one believe the shy lake-dwellers real, who on sight of our approach move in their canoes like shadows across the twilight, dive into the Lake and disappear, never to be seen by us again.

The removal of the base from $\mathrm{Yo}_{0}$, thirty-six miles north of Kaddai, necessitated several journeys of the boats, so that that part of the Lake along the western shore became well known to us. The boats took a course varying from one and a half to two miles from the land, where the average depth of water was $3 \mathrm{ft}$, with a hard bottom. This was in December. In March the depth was $4 \mathrm{ft}$, an increase probably to be accounted for by the Lake having received its full complement of water from the Yo river.

With the exception of a few reed-islands where there is no firm ground, there is good open water all the way in a broad stretch sometimes extending twenty miles out, but nowhere deeper than $4 \mathrm{ft}$.

The shore here is quite open, with rough grass, frequented by kob, gazelle and large herds of hartebeest. This grassland belt is about a mile and a half wide, and beyond it lie thick woods of mimosa.

All the way, the shore line curves in gentle bay formations, and the Lake can be reached without difficulty, for there is hardly any marsh and the land is firm with a sandy soil.

The object that we set ourselves in this first journey was 
to gain the eastern shore and, following it southwards, reach the mouth of the Shari; so we made our course for the southeast. There was a head-wind blowing, which necessitated pole-work all the way. Prepared for deep water we had taken paddles and a plumb line, but nowhere could a depth of more than $2 \mathrm{ft}$. be found. For the first twelve miles we were skirting on our right the outside of the belt of reed and maria that had hidden our view of the Lake as we rode from Kowa. The further we followed, the thicker it became, throwing out headlands of reed into the Lake that formed large bays, across which we pressed to reach the promontory ahead, ever hoping to find, on rounding the point, that the wall of reeds had given way for an open passage to the south. But though this reward was always denied, our ardour was not damped, for every fresh obstacle meant detail in the map, and the whole way Talbot was busy taking angles, while I sketched the route.

At three miles from the start an attempt to push south ended in the boat grounding in thick mud. So we sent out men to wade ahead and see if more water could be found, but their efforts met with no success, and we were forced to drag the boat back over the way we had come and, once more afloat, make a passage in deeper water to the northeast. Throughout the day the sun had been intensely hot and beat upon us with doubled power, as its rays were thrown up with a fierce glare from the water. The mirage hung upon the Lake, blurring the outlines and magnifying the masses of the headlands beyond. When a halt was called the boys tried to cool themselves by jumping into the water, but this only made them more hot with the efforts it entailed 
of scraping off the thick, black mud afterwards. So we held on throughout the day, always on the look-out for a passage south, sometimes pressing in till the boat grounded in the mud, and then sending out waders ahead, in fruitless efforts to discover deeper channels where the boat might float. As the sun sank past the meridian, the mirage vanished and the island-headlands that had appeared shadowy and phantasmal in its thrall, now stood out sharp and clear against the opposing light. But their show of substance only mocked us, for, one after another, as we touched, proved to be merely a mass of reeds standing in the water, with no rest for the sole of one's foot. Now we began to feel anxious as to where we should find a camping-ground for the night, and pressed on past point and point ever in the hope of finding firm land. The sun was sinking fast and the headlands stood out black and strong against a fiery, copper glow, beckoning us on like siren rocks.

Already the more frequent sounds of the polers slapping their flesh warned us of the attendant terrors of the night, and restlessly we redoubled our efforts, aware that the southern dark would leap upon us suddenly and hold us benighted in the boat. Presently, on rounding a headland, we spied through the gathering gloom a large Buduma fleet of canoes about 500 yards distant across the bay evidently engaged in pulling up their nets. Here was our chance; they had not observed us, so under cover of the dusk we stole silently along under the lee of the promontory in the shadow of the reeds till we got within 400 yards of them. Then they sighted us; whereupon a great commotion followed and we could see boats and Budumas darting about in all directions. 


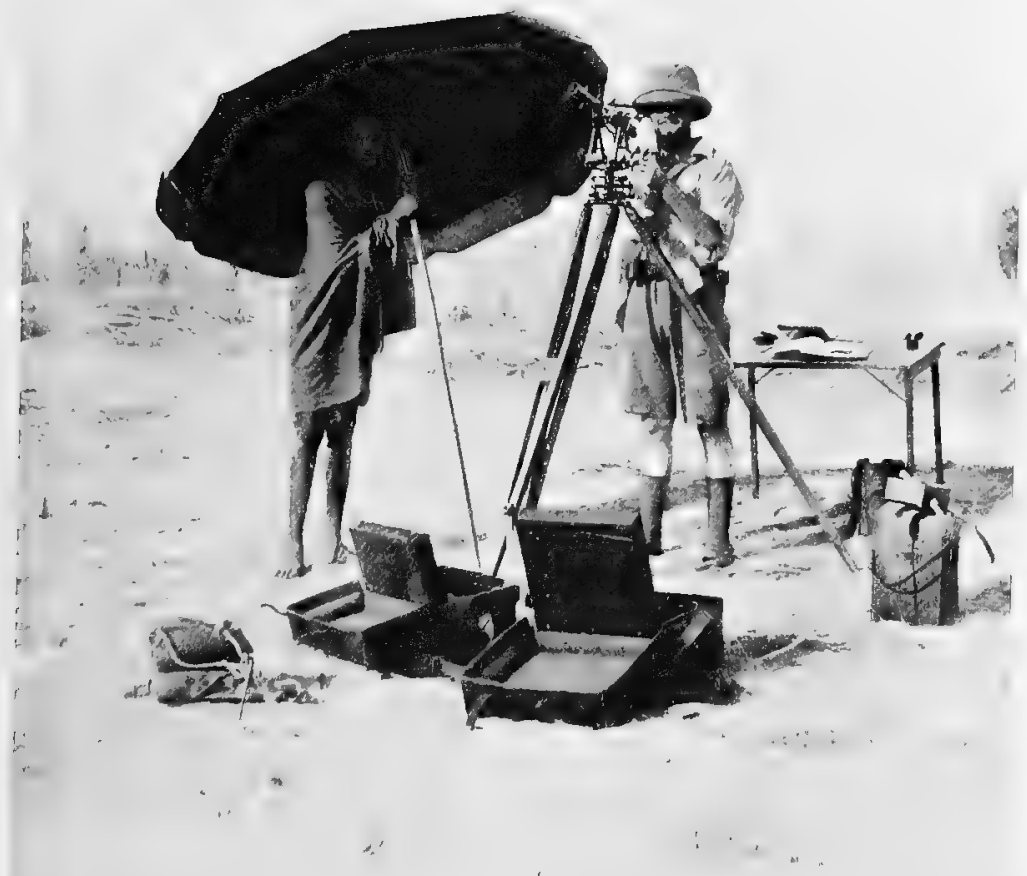

TALBOT WITH THE THEODOLTTE 

When our polers realised what was happening they put on a tremendous spurt and sent our boat along grandly. But the effort was vain; when we arrived upon the scene boats

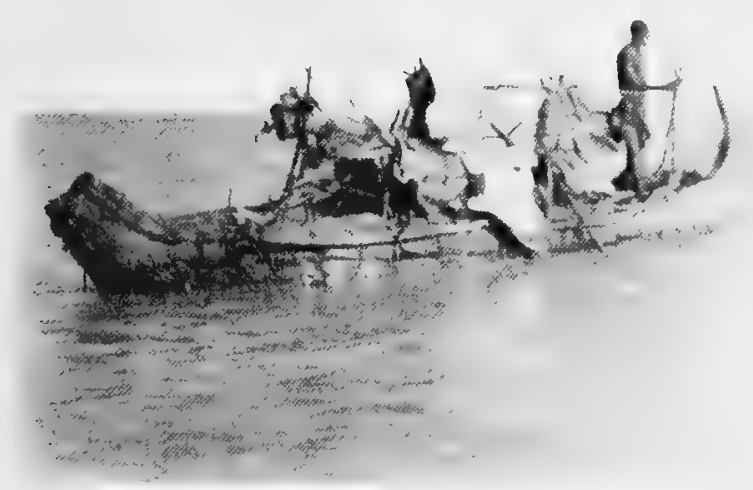

A BUDCMA CANOE LADEN WITH DRIED FISH

and men had disappeared into the reeds with amazing suddenness, leaving behind them only three of their large canoes, which were too heavy for them to move.

We had been in hope, had the Budumas not run away, of getting information that would bring us to land, or better still, perhaps persuade one of them to go with us as guide. But, as it was, we had to be content with what they left behind them, and we were soon busy arranging two of the canoes as our dwellings for the night. We found them full of the fish that had just been caught, while that which was already dried was slung on a frame-work of poles 
fixed round the sides. They were about $18 \mathrm{ft}$. long and, like all the Buduma canoes, made of bundles of small reeds tightly bound together into lengths about 10 in. thick, which are again bound to each other in the structure of the whole. They take about a month to build, are very strong, lasting for two years or so before they become water-logged. Their average length is $18 \mathrm{ft}$., but smaller ones of $8 \mathrm{ft}$. are used for the very shallow places, or for quick escape from sudden surprise. Their prows arch to a high point, which gives them a very picturesque appearance, rather like the Venetian gondolas. In the forepart of each canoe there is a flat stone, fixed to the reed bottom by mud, and on this a fire is kept burning for cooking the fish. Every fishing-fleet is accompanied by one or two canoes laden with wood for the replenishing of the fi es. In one of the canoes were also some shields and spears, armament which the Budumas always carry for offensive and defensive purposes against others of their tribe, for they are all piratical and prey upon each other. The shields are peculiar in form, about $4 \mathrm{ft}$. long, arched, and oblong, and made of the ambatch, or maria tree. There were no poles in the canoes; the wooden structure for the fish-drying made it impossible for polers to work, and the canoes would have been propelled by men wading or swimming behind, a method I have seen the Budumas use on subsequent occasions, and one that at first gives a very weird impression, quite in harmony with the characteristic loneliness of the Lake. Particularly is this so when in the evening light the tall prow of a canoe piled high with white slabs of potash or hung with the gross forms of gigantic 
fish, empty of human souls as a phantom ship, and seeming moved by no earthly power, looms up in the western glow and silently passes, soon to fade in the mists behind. Without foreknowledge one would not discover the small dark dot of the head of the swimmer who is pushing the canoe from behind.

Our first night spent upon the Lake was not a happy one, unless by comparison with some that were to follow. Certainly, our discomfort was lessened by the extra sleeping-room

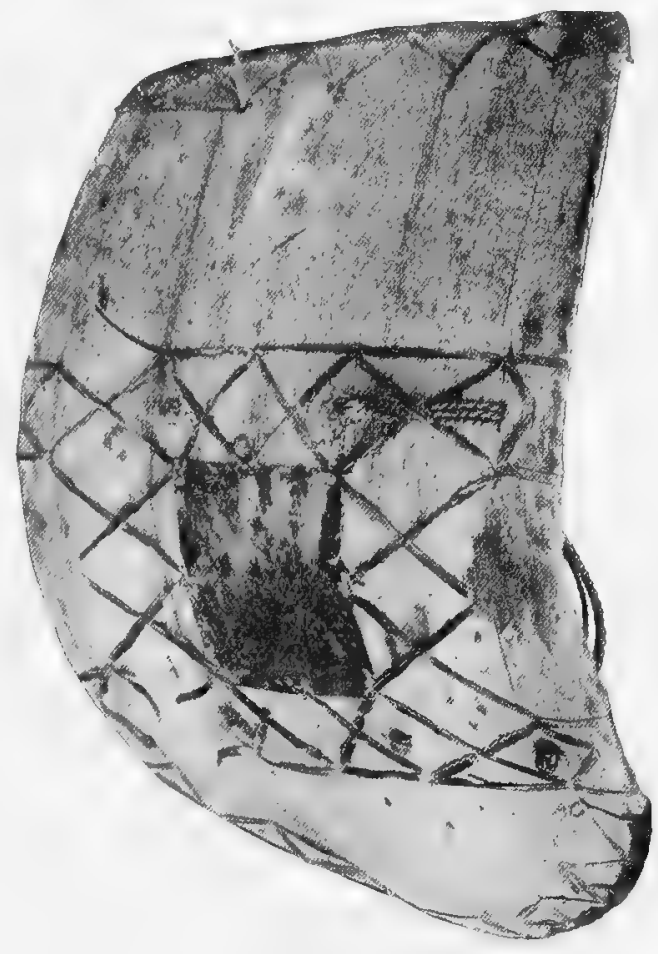

A BUDUTA SHIELD afforded us by the Buduma canoes, and for a while too, the "boys" were happy glutting themselves on the fish, which for the greater part was imperfectly dried and stinking. But with the distraction of supper at an end and sleep the one boon desired by all, the hordes of mosquitoes, which up till now had seemed satisfied with " sniping tactics," concentrated their attack in battalions, and then all things were equal. After the weary hours of torment in the dark the first flush of light on the eastern horizon was welcomed 
as the smile of Peace, herself; but no sooner had the last mosquito withdrawn his attack, than a new terror arose in the swarms of foul flies that crawled out of their sleep in the piles of rotten fish and attacked with a heavy bite that, compared with the mosquitoes', was as the hack of a butcher's dirty knife to the clean rapier thrust of a gentleman.

Even the Buduma, inured by long use to the mosquito, still treats him with respect, and his method of guarding himself against attack is interesting. With the help of his toga and two bent withies he makes himself a tiny little tent like a gypsy's, under which he crawls and curls up like a dog for the night in a most astoundingly small space.

In the morning we were up to breakfast by six, anxious to run away from the new winged pestilence that had assailed us. But before starting, we hung up cloth in one of the canoes in payment for our entertainment, hoping that our hosts would return and find it.

The day arose to meet us with a high harmattan wind which sent a cold mist upon the Lake and turned everything to grey. As it was a head-wind, poling was harder work and our going was made slower. But, "'tis an ill wind that blows nobody any harm," and it was not long before its keen edge had paralysed the tenacity of the flies that had made up their minds to accompany us. As we travelled on through the morning hours the aspect of the Lake gradually changed and the face of the water to our left became studded with innumerable little islands of sand, overgrown with high grass, and many of them strewn with shells. Our course 
now lay for some hours threading the straits that wound two miles wide between the reed-bays and the islands. The water was beautifully clear; sometimes we were passing over a firm and shelly bed, but more often it was covered in layers of dark mud, that varied from a few inches to unknown depths. Presently the reed-belts on the right grew gradually less and their monotonous dark green began to be broken by flat stretches of yellow sand, which we hailed joyously, feeling that at last we had broken down the barrier to the south. Soon the reeds gave way altogether and all along our right low-lying land stretched into the distance. As we had not come more than twenty miles, and as on all previous maps the Lake was made at least fifty miles across, we very naturally supposed this to be a large island and were in high spirits at the prospect of soon rounding it. But, all the rest of that day we were tantalised by its nearness, for, although we made many attempts, we found it impossible to get the boat to the land over the mile or more of thick mud.

All through the day we kept a sharp look-out for Budumas, but never set eyes upon a soul, though sometimes on the lee-side of the islands we discovered their fishing-stations, which were revealed to us by the flocks of gulls seen circling in the air. Our coming gave the birds a brief chance of plunder, for long before we could catch sight of them all the Budumas had disappeared into the reeds, and the gulls then swooped down upon the fish, smothering the canoes in white clouds. Excepting occasional duck that were very wild and rose a long way from us, the gulls were the only life we saw upon the Lake; and the apparent solitude of the islands 
was not broken till I landed once and set the grass alight. Then there flew up, seemingly from nowhere, a number of owls, which at once commenced to prey upon the small rodents that the fire had set upon the run.

That night there was room and to spare, as we made our camping-ground upon one of the islands, and got good sleep, for a strong wind during the day always scatters the ranks of the mosquitoes, nor do they rally in time to attack in full force the same night. Still they were never so scarce as to make our star-work possible, so we always had to take latitudes by day.

On continuing our journey the next morning we discovered that the wind had proved a mixed blessing, for to our dismay we found that the water had sunk $10 \mathrm{in}$., having been carried westward by the wind to leave a depth of barely 7 in. So all that day we toiled heavily along, making very little progress, with the boat often scraping upon the thick mud. The little incidents on the way did not vary much from those of the day before, except for one island where we came upon a flock of pelicans fishing. For a long way on our right the low line of land continued unbroken by any feature, and then our hopes were raised by the sight of what we took to be a Buduma settlement. Here after much difficulty we managed to land, but on approach the place proved to be a deserted cattle-station. It consisted of a ring of very small, round huts, not more than $4 \mathrm{ft}$. high, built of reeds and plastered with mud on the sides that faced the prevailing wind. All were quite bare, with no trace of recent occupation.

We passed several more days without seeming to 
get any nearer to finding the passage of the Lake, with always the endless islands on our left, and to our right the monotonous low land, where once or twice again similar, deserted cattle-stations enticed us from our course on the same laborious fool's errand.

We had now spent a week upon the Lake, working hard

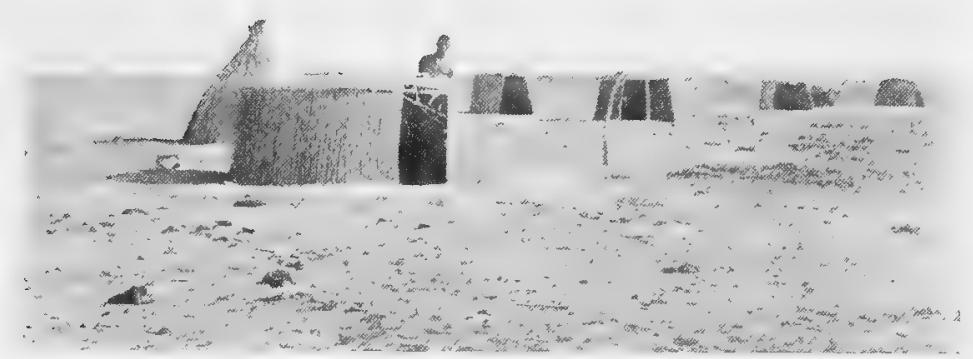

A BUDUMa CatTle-station ON LAKE CHAD

to make progress, taking observations and mapping the route the whole way. Yet we were still completely in the dark as to our whereabouts and not much nearer than when we started to a better understanding of the Lake. And now a more serious trouble presented itself, for we found our provisions had run out, and our gorges rose at the thought of having to eat the rotten fish that the Budumas left behind in their canoes. Nor had we the means to catch fish for ourselves. Our plight seemed alarming and we began frantically wading up to our waists in the mud after duck. But our efforts were attended with no success, for the birds took to flight instantly before so strange an 
invasion. We therefore were obliged to turn to the flocks of gulls which often circled above us, and it was not long before we had spitted and roasted a brace before the fire in the boat. The following evening, however, our case became still more serious, for our cartridges were almost finished and hunger forced us to make for the rats which abound on the islands. We dug them out of their holes and made humble pie of them. And this was how we lived for another six days. To make matters worse there was nearly a mutiny of the crew, incited by the worthless kinsman of Adamu, who had long ago proved an impostor, without the smallest knowledge of the Lake. He now turned out a coward into the bargain and we found him working on the fears of the "boys," telling them that we would all be lost and starve to death or only survive to be taken by the Budumas for slaves. As a firm hand had to be shown, the scoundrel was ordered up for punishment. At this his courage failed him, and, breaking away, he made off for the reeds. When he was gone far enough to make no stigma attach to us for missing him, we sent a couple of bullets flying over his head just to give him a hint of the kind of reception he might expect, should he be so rash as to return. With Jonah overboard order was restored once more, and the crew settled comfortably to work again as if they had sent a scapegoat with their sins into the wilderness.

We were now beginning to realise the hopelessness of continuing our search for a passage to the south, for ever since our start reed-belt and island had consistently pushed us northwards, and now we were heading straight for the Pole. Moreover, we had been away on the voyage 
nearly twice as long as we had intended, so we thought it high time to bring our trip to a close. We therefore changed our course to west, and, after a few tedious hours of winding

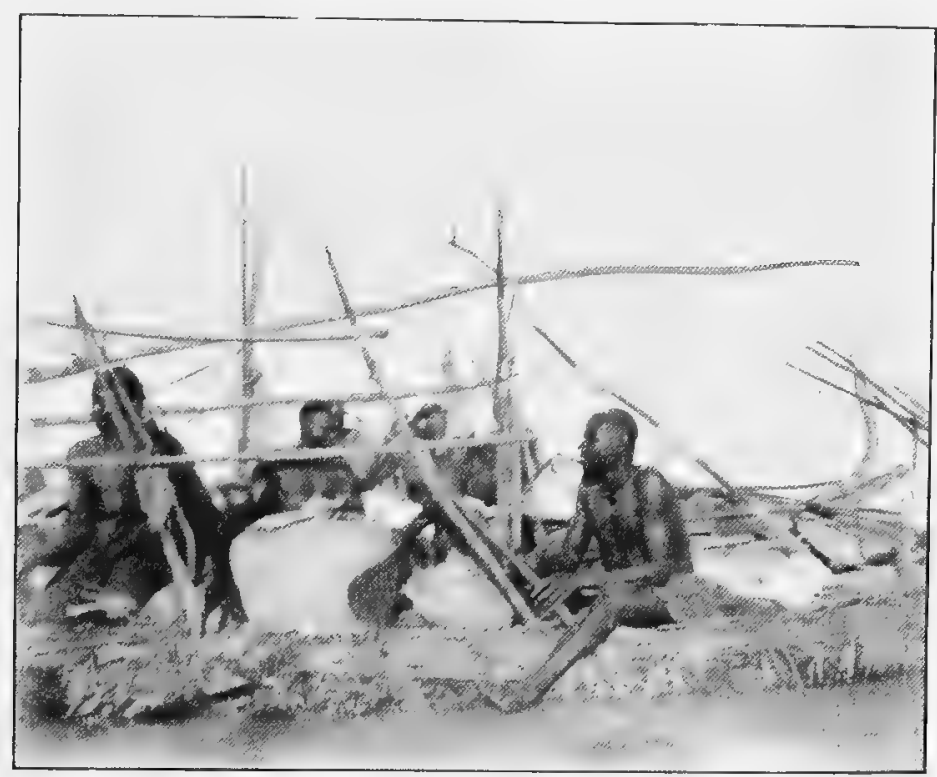

BUDTMAS IN THETR GRASS CANOES

through the shallows in a network of small islands, we emerged into open water with a depth of $2 \mathrm{ft}$. This continued for a distance of twenty miles till the mouth of the Yo was reached. We made good going all the way, for we had the wind now behind us, so were able to make use of the sail, which took us merrily along. Towards the afternoon we came into $3 \mathrm{ft}$. of water, and along the horizon there appeared the low line of land. Presently we sighted a large Buduma fleet, heading in our direction, so we at once hastened our pace with poling. As soon as the Budumas became aware of us they put about and fled. But the sail 
gave our boat superior pace, and we were overhauling them fast, when realising that flight was hopeless they hove to. As we neared them their headman came wading towards us with two large fish in his hands as a peaceoffering. There were about twenty canoes in the fleet, each carrying three men, and piled with nets. They were bound with their catch for some baga, but we could not get much information as we had no one with us who could speak their language. They were a remarkably fine-looking lot of men, of heavy, muscular build, very sleek and glossy of skin, as are all Budumas from their habit of living almost entirely on fish. They also anoint themselves with oil, extracted from the heads of the fish, as a protection against the harmful effects of their long immersions in the water.

We found we had calculated our direction to a nicety, and soon were sailing into the basin at the mouth of the Yo. Here a wonderful scene presented itself, which came upon us as a strange contrast after the days of wandering in loneliness upon the Lake. For, suddenly we were in the midst of a great variety of life, and everywhere around us was a sense of bustle and stir. Smoothly we sailed into the deeper water of the basin, and as we neared the land the line of green trees told out beyond the level of burnt-up grass and sand, and we could discern herds of cattle and flocks of sheep with their shepherds. Against the island sand-banks which lie across the mouth of the river, rows of canoes were riding between piles like gondolas, and on the islands the owners were working in little groups, drying fish or mending nets; while flying round them and 
sitting in little parties upon the water were flocks of white gulls waiting for the refuse to be thrown away. This was

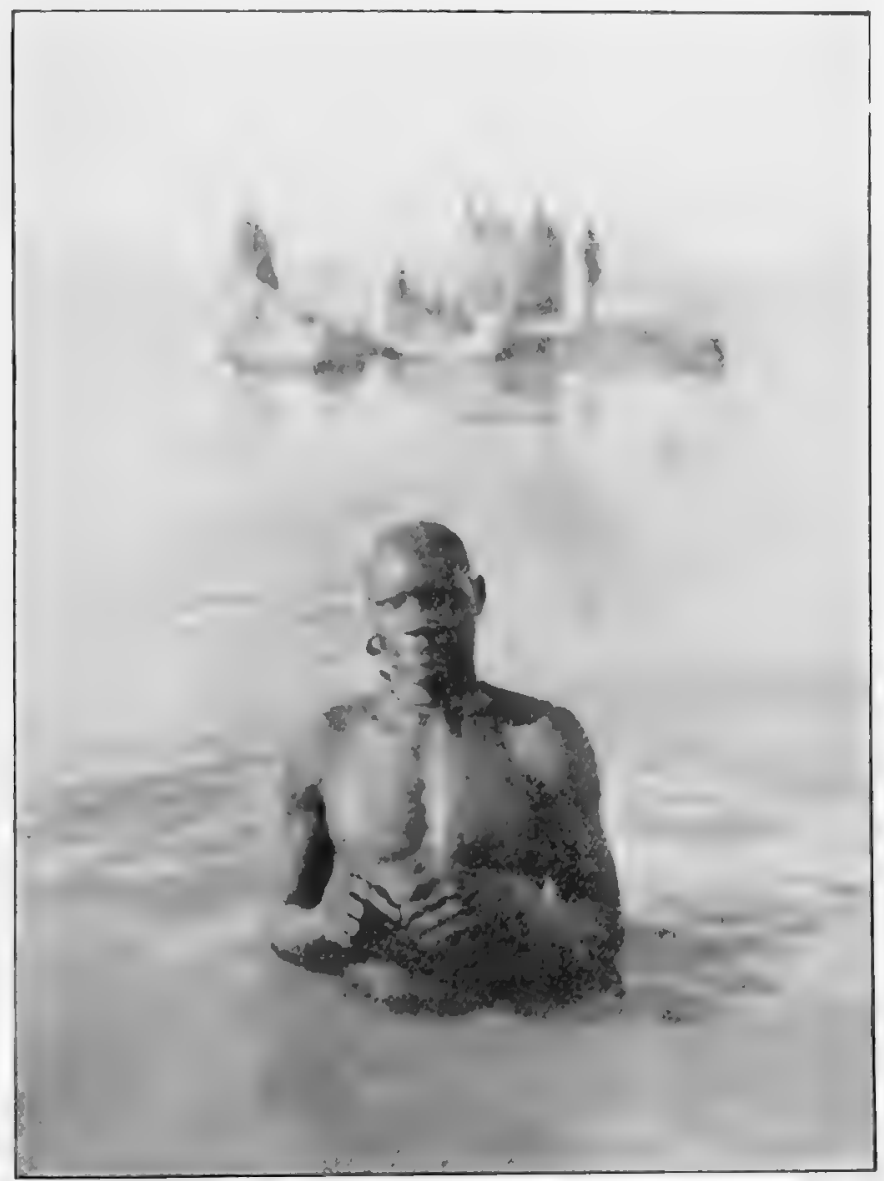

HEADMAN OF THE BUDUMA CUMING TO WELCOME US

the time of the great fish-harvest, for the river was fast emptying itself and thousands of fish were coming down daily into the Lake. Here and there in the water were naked fishermen, their skins shining like wet bronze in the sun, wading up and down with spears poised aloft for 
the throw. These spears are made so that the head when it strikes a fish comes away from the shaft. A cord is attached to the head and also to the arm of the thrower, by which he hauls in the fish. There were feathered fishers as well upon the scene, and it was a wonderful and extraordinary sight to watch the birds at their fishing. Scores and_scores of pelicans were swimming about in ordered phalanxes, which shone most beautifully in the sun, for the delicate rosy tinge upon their plumage has the effect at a little distance of making it a most living white. Seemingly upon a signal, they extended in a long line, in formation of twos, and swept a circle to the shore, driving the shoals of fish before them. As they neared their prey they started beating the water with their wings to prevent the fish breaking back past them. Then followed a tremendous commotion like the quick work of a bayonet charge, and right and left the great bills were stabbing the water, which churned and hissed under the strokes of the gigantic wings.

Solitary long-legged storks, standing stock-still in the shallows, like sentinels, pursued the pelicans when they came within range and made them drop their prey. 


\section{CHAPTER XVII \\ CHRISTMAS IN CAMP AT KADDAI}

THat night we camped upon one of the small islands at the Yo mouth, and the Budumas came and gave us large presents of fish, but beyond smiles and handshakes we could get nothing out of them. Even afterwards, when we were able to understand them through a Kanuri interpreter, they were sparing of information, and that they gave was nearly always incorrect. When questioned about the geography of the Lake, they always expressed a profound ignorance.

Gosling, who was at this time at Kaddai, sent to see if he could get a man from the Lowan of Kowa, to act as a guide, but the men of Kowa were all out chasing a party of Tubus, who had been raiding in the neighbourhood. The Lowan had told the Budumas that we were friends, but they replied that though they were not afraid, they did not wish to have anything to do with us. No doubt they are very jealous of their possession of the Lake. Those at the Yo mouth were not so shy, for they had got used by now to our boats, which had done the journey between $Y_{0}$ and Kaddai several times; besides, they were accustomed to seeing strangers at the neighbouring markets. They were in the habit of taking most of their fish to Kaddai before our coming drove them away, to sell it to merchants from Kukawa, but there was also a small market going on at the 
Yo mouth the day we left, where Budumas were exchanging their fish for corn, which they do not grow themselves, and which the Mobburs brought down on donkeys from their villages along the river.

I must not forget to mention the pelicans again before we leave this part of the Lake. In the morning we watched them fishing in the channels of the river mouth, where the belated fish were coming down in great numbers, many to be cut off and left behind in the pools. Here they were beating the river in two columns, which advanced, one up, and the other down the stream. As they met, they started up with a flapping of wings, and having formed a circle round the fish, were soon employing the same tactics as I have described in the last chapter.

There is little to say of our journey to Kaddai, for we were working too closely, mapping the western shore-line, to allow of the occurrence of fresh incidents. Ordinarily, when there was a wind for sailing, the boats accomplished the distance in a day, but this time we took five over the journey. Talbot travelled in the boat, while I went along the shore, mapping its outline. We kept one another in sight, and he landed each evening in time for "chop," and to camp the night. We lived for the most part on fish, for we had got a good supply of the dried sort for the "boys," and some fresh for ourselves, which we replenished the second day from a fishing-station on a small island, whence the Budumas had, as usual, disappeared on our approach. On the third day we arrived opposite Arregi, a village four miles inland, where we sent in and got corn and fowls. That night the harmattan brought the water up 500 yards, causing 


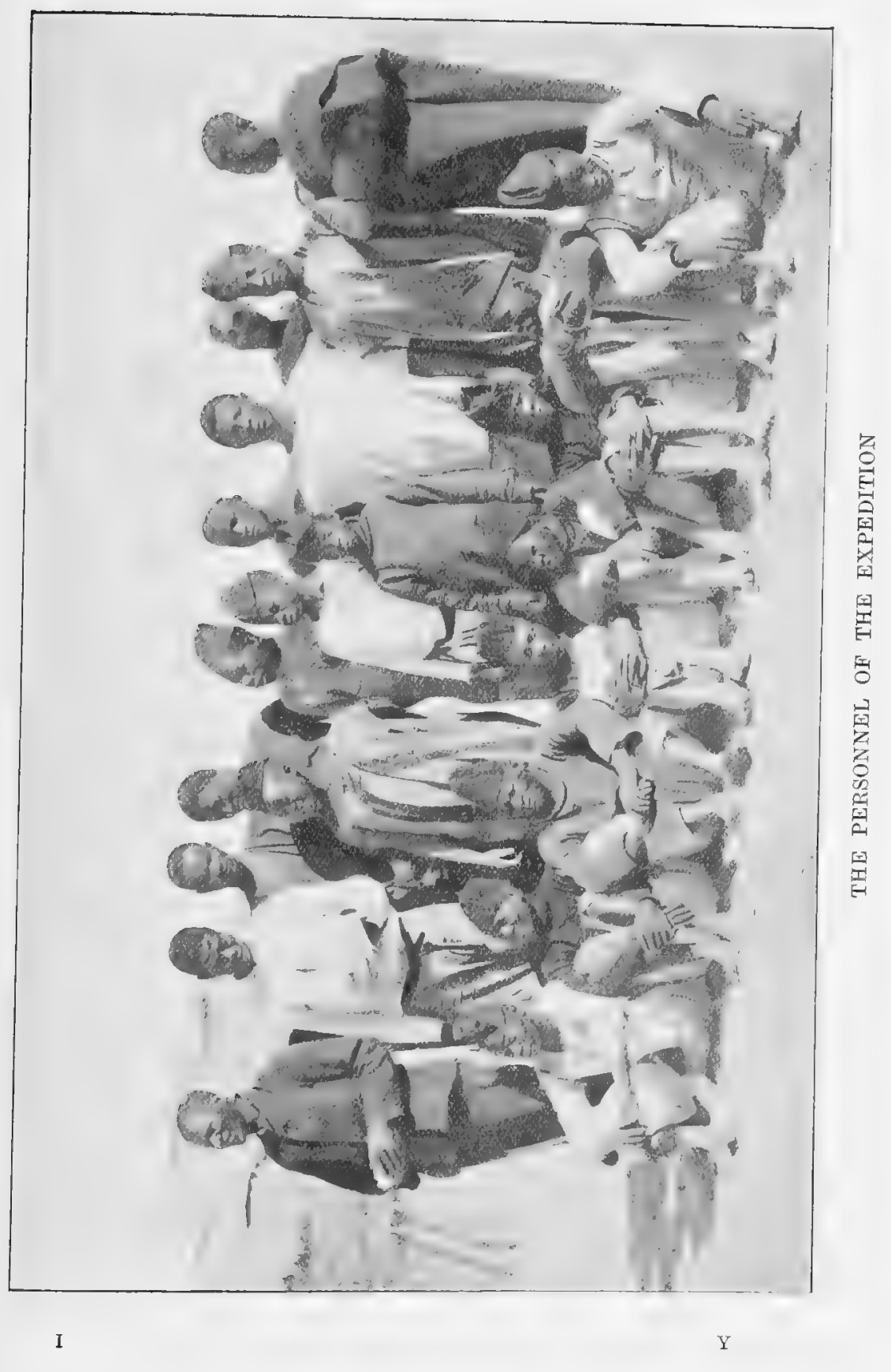



us to jump out of bed suddenly and retreat farther inland. This was our first experience of being caught napping by the invading Lake, and it struck us as very strange and weird, for one would have expected water driven all that distance by the influence of the wind to have given warning of its coming with the lapping noise of waves, but there was not a sound of a ripple as it swiftly stole up the land. Upon this trip in particular, Talbot noticed numbers of dead and dying fish, some $4 \mathrm{lb}$. in weight, floating upon the water, a not uncommon sight anywhere on the Lake; they were the victims of a large stinging fish. On catching sight of the carcases, the "boys" used to make for them and collect them for their supper, not passing by even those that had been drifting long enough to make their presence felt upon the air. But all the "boys" had to yield the palm in this respect to one of the biggest of the Nupe polers, whom they nicknamed "Kurra," or the Jackal, for his voracious appetite and predilection for carrion.

Now and again along the plain I saw the pretty sight of a party of five or six white-rumped Dorcas Gazelle, feeding among the maio bush. These are by far the most interesting of the Sudan gazelles. They are extremely shy, and it requires very careful stalking to get within range of them. Their hind-quarters and legs are pure white and make a sudden contrast to the rest of the body, which is an almost uniform chestnut merging at a distance into the surroundings, so that their forms are difficult to make out, especially through the haze of the prevalent mirage. Several times under these conditions we mistook them for natives in white 
bernouses. This country marks their western limit of distribution from Kordofan.

In the afternoon of the fifth day we sighted our other boat in the distance and at once hastened our pace, happy in the realisation that we were so near home. But she appeared to have caught the characteristic shyness of the other craft of the Lake, for she at once took to her heels and disappeared. At this we made up our minds that she could not have seen us. However, all was cleared up later when she appeared again, and we were soon alongside talking to José, who explained that there had been great anxiety in the camp at Kaddai for our welfare, for we were known to have left with only five days' provisions, and now it was three weeks that we had been away without their having any news of us. So they were entertaining all sorts of gloomy forebcdings, and had prepared to start the next day on an expedition in search of us. Thus it was that José, on sighting us, put back at once to tell Gosling the news, and then came out again to greet us. On nearing the shore, all the camp turned out to welcome us, wading out into the water to carry us in from the boat. The "boys" were eager in their hand-shakes and inquiries, which was very gratifying, for absence seemed to have made their hearts grow fonder, thereby proving that after all they possessed the organs which develop sensibility by separation, but which in the trying conditions of daily intercourse one had long ago ceased to credit them with.

We returned to find that Gosling during our absence had got the camp into first-rate order; in fact, it had all the appearance of a well-established community that had come 
into existence for the development of some flourishing industry, instead of being only the temporary base of a people who depended less on the land and moved faster than the wandering Arabs or gypsies. With the soldiers, carriers, polers, and servants, all told, we numbered over 200 , and that did not include the wives of the carriers. This meant the erection of huts; otherwise, as it was now the dry season the "boys" were content to sleep round the fires, so besides the three houses that the Shehu had caused to be built for us, our little township included lines of huts that the carriers made for themselves and their wives. Round all these ran a zareba against the possible night-attacks of wild animals, the making of which gave useful employment for some time to a number of the men. Besides this work there had been the digging of three wells. The water of these was excellent and very strongly impregnated with potash, which, to my taste, made it more palatable, and I always noticed on drinking it after coming in from a long day's tramping that its effect seemed more stimulating than other water. In one of the wells a white owl took up its abode in the crevices of the rocks. These birds are like our own barn owls, only more remarkable for their breasts, which are speckled over with dark spots.

With regard to the water of the Lake, on the numerous occasions when we drank it, we always found it sweet; which agrees with the opinion of Nachtigal, although other travellers have described it as salt to the taste. It is, however, likely that in parts not so directly affected by the influence of the rivers there are springs impregnated with potash. There are 
salt-making settlements in the bush between Kaddai and Yo, and we could see from the camp their fires burning the whole night long. The native process is interesting. A well is dug, and from the clay extracted a pot is made. Then the branches of a mimosa are burnt, the ashes of which are placed in a basket on a structure of wood; water is poured upon the ashes and trickles through into the pot below. The contents of the pot are afterwards boiled away till they leave a sediment of salt. The Kanuri use the same method, only substituting dried grass which is not nearly so satisfactory as the wood.

As may be imagined, it was not always easy to find employment for so large a number of men and keep them out of mischief, for it was not long before the people of the neighbouring towns of Kukawa and Kowa came to know of our whereabouts, and, besides the traders who came down to do honest business, there was always the inevitable tag-rag of worthless characters of both sexes. As I have described in a previous chapter, it was here that people came from long distances to buy our famous cloth. One trader travelled all the way from Fort Lamy, a fifteen days' journey, to buy three pounds' worth !

For the most part the men were employed cutting wood for the fires, which were kept going through the night as a protection against mosquitoes and for warmth, for the nights were chilly; the thermometer sometimes fell to $46^{\circ} \mathrm{Fahr}$. in the early morning, and later, in January, recorded a minimum of $32^{\circ}$. Then there were periodic journeys to Kukawa for food, and sometimes a certain number of men were employed on hunting expeditions. For all there was 


\section{CHRISTMAS IN CAMP AT KADDAI}

military discipline maintained with regular parades and inspections. It was at this time that we picked out nine of the carriers and drilled them as soldiers, fitting them out in

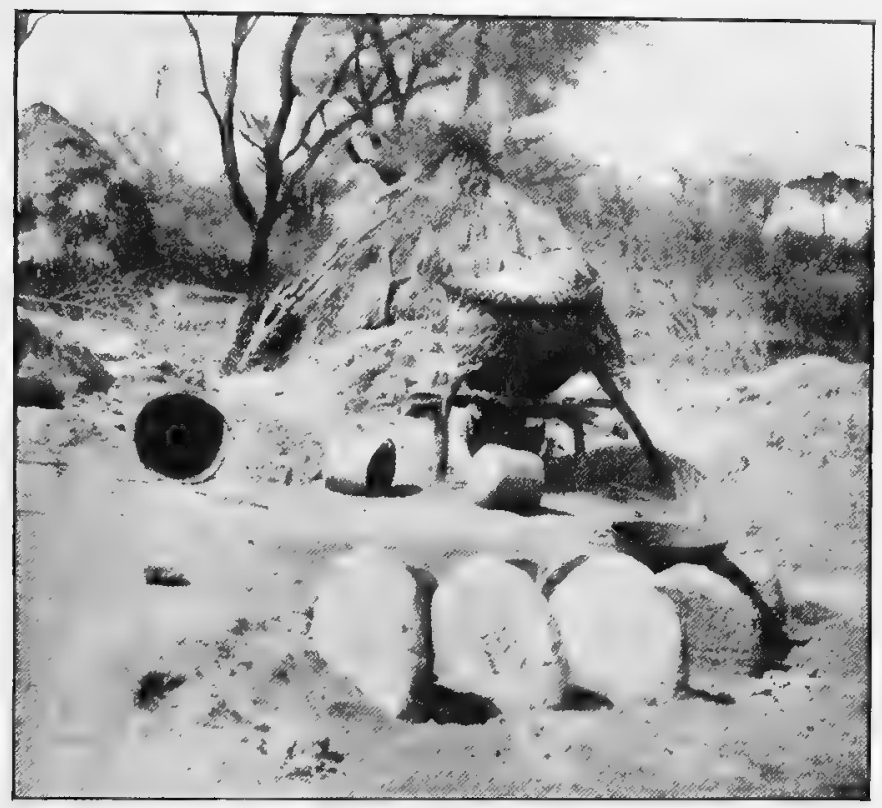

KANEMBU METHOD OF SALT MAKING

a uniform of white "shorts," vests and fez caps, which we had brought out with us from England for the purpose. For it was necessary to send back the soldiers of the Protectorate before crossing the Lake and entering French territory. In a very short time they were efficient at their work and took a great pride in themselves. In almost every case the native of Africa is excellent material for the making of a soldier, and he takes great pleasure in the little details of drill. It was a frequent sight in camp of an evening to see Quasso and Lowi playing at soldiers and drilling each other, with odd 


\section{FR()M THE NIGER TO THE NILE}

attempts at reproducing the word of command. Twice a week we held a bathing parade, and the whole camp had to

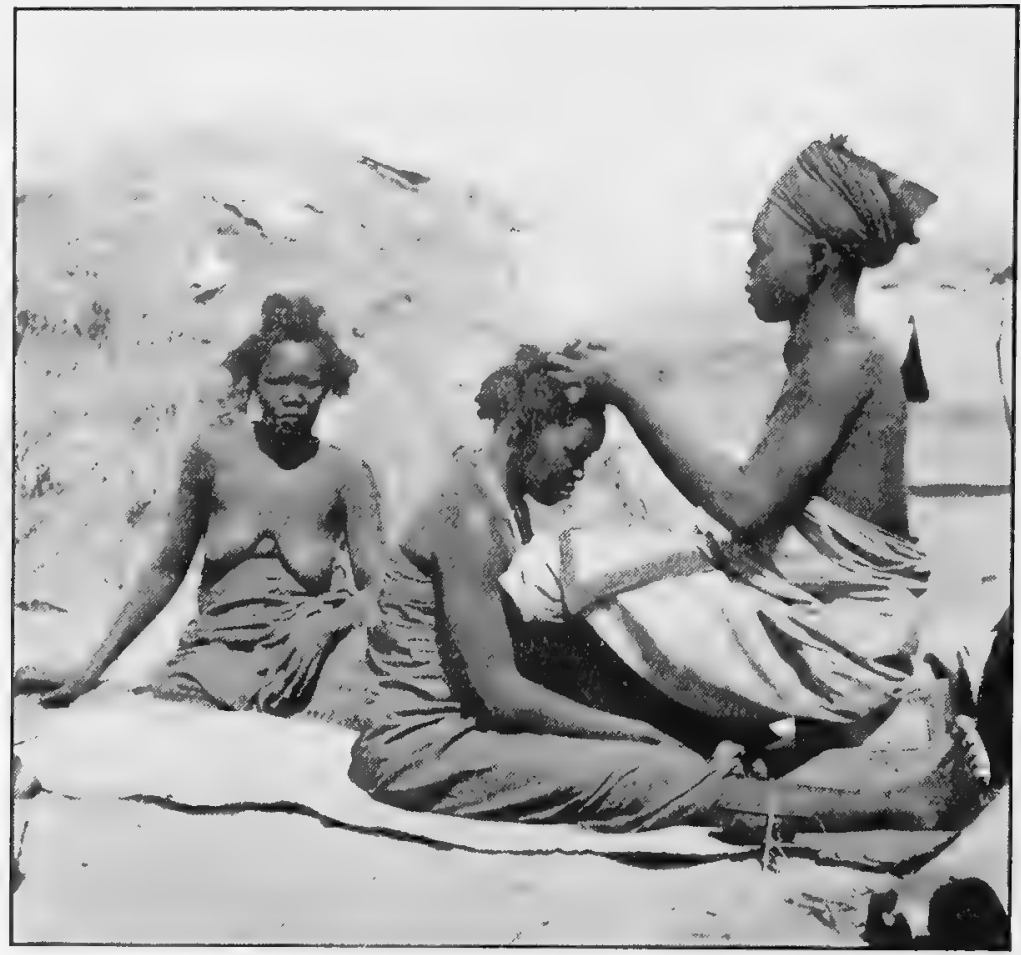

HAIRDRESSING IN CAMP AT KADDAI

turn out, strip and take to the water. At first there were many shirliers to deal with, but soon they began to find benefit and even amusement in the habit, and the bathing drills came to be looked forward to as a pleasant diversion rather than a duty. Taking them as a whole, and considering the slight ties beyond the immediate reason of gain that held so mixed a crowd together, it was really wonderful how con. tented and amenable to discipline our followers were. Their 


\section{C'HRISTMAS IN ('AMP AT KADDAI}

one great vice was gambling; of this they were quite incurable and cases of quarrels and discord among themselves were almost always attributable to this cause.

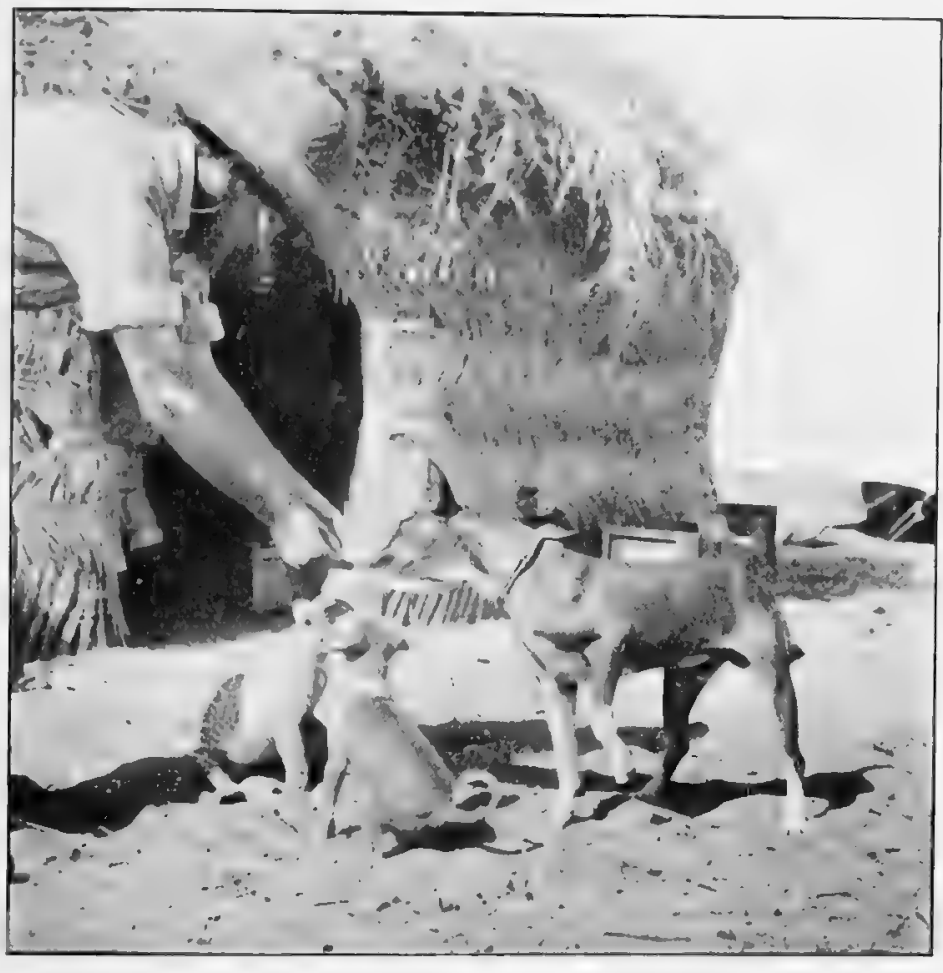

"DAMESSA," "MAIFONI" AND "WUKA"

I must not forget to mention the other members of the camp, who were personalities and succeeded in attracting a good deal, if not the greater part, of our attention to themselves. There was Damessa, the leopard cub, and Gosling's jolly little mongrel, Wuki, neither of whom need an introduction. These two were firm friends and enjoyed many a romp together, and were even able to endure the severe test 
of feeding from the same plate without differences arising. And now Maifoni was cordially received into the family circle by them without being required to undergo any term of probation. Then there was a donkey and her foal, which claimed a certain amount of notice from the interesting fact that it was here with us that they elected to start separate existences. Besides these, there were three other donkeys, a few sheep, and last, but not least, six horses belonging to the members of the party. Later on, when the Kanembus got more used to us, a frequent and pretty sight to be seen in the country surrounding the camp was the flocks of sheep and goats, divided into little parties of about a hundred, each under the lead of a shepherd boy and his dog. The boy was always nude except for a skin slung over the shoulder, and in his hand he carried a crook and spears. He irresistibly reminded one of the shepherd boy David, tending his father's flocks. Here, as in the East, the shepherd is always with his herd, which gets to know him and looks to him for succour and guidance in every step it takes, ever following his lead and never requiring to be driven. No doubt our presence was looked upon by the shepherds as a protection against the Tubus, and perhaps it was gratitude for this that made them bring us, unasked, a good supply of milk, for which they did not want to be paid.

Another pretty sight that one never got tired of watching was the morning and evening flight of sand-grouse passing over the camp to water at the Lake. There were hundreds of them, and they flew very high in wedge-shape formations, which, on reaching the shore-line, dropped like arrows into the water. 
Talbot was to leave the day after Christmas, and for the few days before, I was very busy labelling and packing my collection of the Bornu birds, which now amounted to over eight hundred. He also took with him Gosling's collection of fish. It was a very great comfort to us to feel that under his charge a considerable portion of the results of our work would be certain to reach England, whereas at other times we had to entrust boxes to natives. With them the chances of loss were very great, yet I was most extraordinarily lucky, and every box that I sent off by natives sooner or later turned up safely on the coast.

The 24th was spent in making preparations for the great day to follow, for we were determined to keep Christmas with as loyal observance as possible. Perhaps the day to us, 4003 miles away, meant more than it can possibly mean at home. I think all travellers in far countries would say the same. For, from old habit, or it may be a call in the blood, the old Christmas scenes come back and the mind returns with yearning to the Christmas days of childhood. Time seems to lose itself in the great distance that lies between the African wild and the kind surroundings of home; one pictures all going on there just the same as years ago, and faces of lost ones steal back to their place in the circle that has missed them long. So one dreams a moment gladly, but then sad memories return to catch one by the throat. These associations bear upon the mind with so much greater force, because they arise out of thoughts that have long been allowed to sleep; for the traveller who knows that he must wander through rough regions for years before he will set his face towards home dare not think long on tender things, or 
he would soon be weakened by home-sickness and rendered unfit for the work before him. Nor does time allow him much opportunity; long spells of work and journeying clog his mind in the waking hours, and at night thought is smothered under the weight of a tired body for which there comes no day of rest. Soon the days are lost count of and go nameless, known only by numbers like prisoners, and the weeks pass without beginning or end.

This particular Christmas called all the more for celebration, for it marked the last camp together. On the morrow Talbot was to leave for England, taking with him as far as Maifoni the Hausa escort and a large number of the carriers, while Gosling was to set out to hunt elephant.

It was important that we should have meat for our feast, so on Christmas Eve, Gosling and José organised a hartebeest hunt on horseback, as the people of Kanem hunt the giraffe. My brother's horse, Mandara, was especially useful for this work, as he was very fast. A herd of twenty was sighted feeding in the open ground by the Lake to the south, and the hunters walked their horses to within about five hundred yards, when the herd started moving. They then rode at it for all they were worth, dismounting at two hundred yards to fire. They were successful in getting a fine animal, which furnished a variety of dishes for the Christmas dinner. In the morning all the camp came and wished us a Happy Christmas, and each received a "dash" of cloth. Umuru and Galadima accompanied their felicitations with a present of mice which they had caught the night before, believing that they would be most acceptable to me, for they regarded all the skins 
of the animals and birds that I collected as my peculiar form of ju-ju. There is little to say of the way we spent the day, save that it was one of delightful rest throughout the camp. In the afternoon the boys held a wrestling match, but dinner at six o'clock in the evening was the great event, and John, realising the importance of the occasion, rose to it with complete success. Here is the bill of fare of the feast he prepared for us :

\author{
Sardines \\ Soup \\ Fish \\ Rissoles \\ Brain Fritters \\ Cornflour and Jam \\ Plum Pudding \\ Tea, Whiskey
}

We spread the table in front of our huts under the starlight of a still night. Afterwards José gave us some old favourite pieces on the gramophone, which sounded very sweet upon the night air and brought to mind memories that made the heart swell. Then the night was ended with pipe and glass and conversation. We talked of the work ahead, with regrets that Talbot would be with us no longer, and we wondered where Gosling and I would be spending our Christmas the next year, and what sort of a feast we should be able to get together.

In surroundings so different from those in which one is in the habit of picturing Christmas time, it was difficult to realise it was the same day that one always associates with the season of frost and holly and homing. Yet out there by Lake Chad, under the stars, with cattle and sheep and horses tethered by, and the glow of the camp fire on the faces 
of the carriers seated on the ground, and beyond the zareba of thorn the blue night over the shadowy plain, I doubt not the scene was more like the first Christmas of all on the night of the wonderful star, when Gabriel came to the shepherds and bade them be first on the road which led kings to Bethlehem.

Next day the camp was busied with the stir of Talbot's and Gosling's departure. With them went the soldiers and about forty carriers, who carried the boxes of heads and skins and survey instruments that we were sending back under Talbot's charge to England. Gosling accompanied him as far as Kukawa. Thence Talbot journeyed alone to Maifoni, where he picked up the rest of his things, including his splendid collection of curios. Thence he went by the Yola road to Ibi, where he procured three canoes for his journey to Lokoja. The Yola road was dangerous at this time, owing to hostile natives, so I applied to the Government asking that an escort might be granted him, but this was refused. As the other way round by Gujba and Bauchi meant the loss of more than a month to the map, which it was most important to publish as soon as possible, Talbot took the risk and got through, fortunately with no mishap. His departure meant a great loss to the Expedition, for he was a tireless worker and set about and overcame his tasks with the greatest accuracy. Not only as a worker but as a companion, Gosling and I missed him very much, so when the evening of his and Gosling's departure saw me having my meal alone, it may be imagined I did not find myself very good company.

From Kukawa Gosling went by way of Kowa to the 
Kowa Baga, a Buduma fish-market which is situated at the end of a promontory, known to the people as Seyurum, where he hoped to get in touch with the Budumas. In order to approach them quietly he got rid of as many carriers as possible, in their stead using oxen for transport, which were lent him by the Shehu of Kukawa. On the road through the maio bush from Kowa down to the Lake, his oxen stampeded in the night, and it was found in the morning that there were tracks of elephants close to their tethers. Taking with him a Kanembu hunter as guide, whom he described as old and grey and armed with a bow of ancestral type, and with fingers covered with silver rings and ju-jus hung all over his person, Gosling followed the path of the elephants down to the Lake. Here they had disappeared into the reeds to cool themselves for the day, so he pitched camp and waited for them to return on their tracks. Next morning he found that they had come out of the Lake unobserved, so he struck camp and followed them. After going through the bush for four hours, the tracks again led down into the Lake, and another night was spent waiting for their return. He describes the mosquitoes as being very terrible at this time. The men dug holes in the earth to sleep in, covering themselves with grass. He, himself, slept by a smoke fire to keep off their attacks, and he goes on to describe the way jackals, kob, and hartebeest came ranging close about him.

Next day he continued the hunt though there were no tracks to show where the elephants had come out of the Lake. However, after following the shore-line towards Kaddai for four miles, Umuru suddenly saw an elephant about 300 
yards off in the scrub, above which only his back was visible. Gosling was between him and the Lake, and the elephant was down wind, so he quickly made a circuit and without any difficulty got to within forty yards of the animal, which now commenced raising his trunk restlessly as though he had whiffed an enemy. So Gosling lost no time and let him have it behind the shoulder, twice in quick succession. At the second shot the beast rocked and reeled, and no doubt had got his death, but for fear he might get into the Lake, Gosling gave him two more below the eye, as he turned. These apparently had no effect, and it took two more to bring him finally to the ground. He was a fine animal, measuring $10 \mathrm{ft}$. from the shoulder, and $25 \mathrm{ft}$. in length from trunk to tail. He carried rather bigger tusks than most of the Chad elephants.

After taking his photograph, Gosling sent back for the oxen and camp kit, and also into Kowa for the population to come out and get the meat. They arrived on the scene the next day to the number of about sixty men, women and children, and all set to work hacking at the elephant, sometimes burrowing right into the carcase, till every bit of meat was cleared off the bones. Gosling describes the butchers' work of the men with their spears and small knives as wonderful to behold. It was not long before the carcase was reduced to a clean skeleton, and the next day saw the scavengers returning home, save two or three families who camped upon the spot while they dried their share of the meat, which they cut in long strips and hung out in the sun.

By now, an extra bullock had been obtained to carry the tusks, and Gosling struck camp on January 5, and, 
without giving previous warning of his direction, moved on quickly and surprised the Buduma settlement at the Kowa

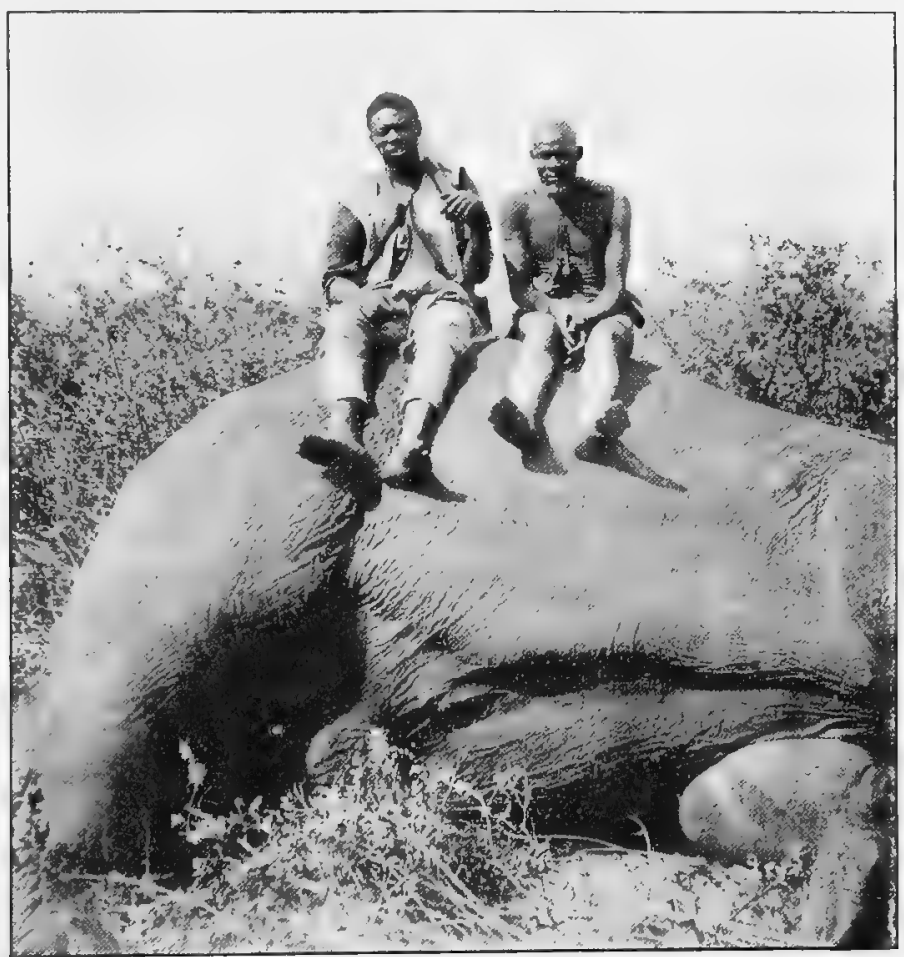

GOSLING'S ELEPHANT

Baga. He was very successful, and only a few had time to take to their boats and get away. These however returned later. The rest were very friendly and brought him presents of fish. He was able to get some good photographs of them, and they took him out in one of their boats to show him their fishing operations. That night he camped about forty yards from the market, hoping to get still further into their confidence the next day. But in the morning they had all 
disappeared as usual. He then returned, and stayed the night at his elephant camp, leaving next day for Kaddai. On the road Wuka smelt out a prize in the shape of a little bush-kitten, and Gosling adopted it at once as a pet and called it "Rabeh." He brought it up on tinned milk and liver. At first it was very wild and bit and scratched any one who attempted to touch it, but soon Gosling was able to handle it with impunity; it would feed on his lap, and later was jumping up on to his shoulders or romping with the dogs. One day Rabeh stalked and seized a tame guinea-fowl as it was feeding in Gosling's hut, but he was discovered and removed from off the back of his quarry before anything serious had happened. He throve and grew apace, and to watch him at play was a picture to behold. But alas! after being the apple of his master's eye for the brief period of six weeks, one night he got past his guard and escaped into the bush. Poor Gosling was very much cut up at the loss and searched the bush for a whole day, burning the grass, but no trace of Rabeh could be found.

While waiting_at Kaddai for my return, Gosling spent the days hunting or making excursions on the Lake. He tried to get through the reed-belt to the South, but failed, as Talbot and I had done. Meanwhile I had gone off with José by way of Arregi and Yo to a place called Gashagar, and thence to Maifoni to collect oxen for the transport of our things to our next base at Fort Lamy. Also I was anxious to complete my collection of the birds of Bornu, and see my brother's grave again before leaving the country. We were much delayed owing to difficulties in getting a sufficient number of oxen, and had to stay longer than we in- 


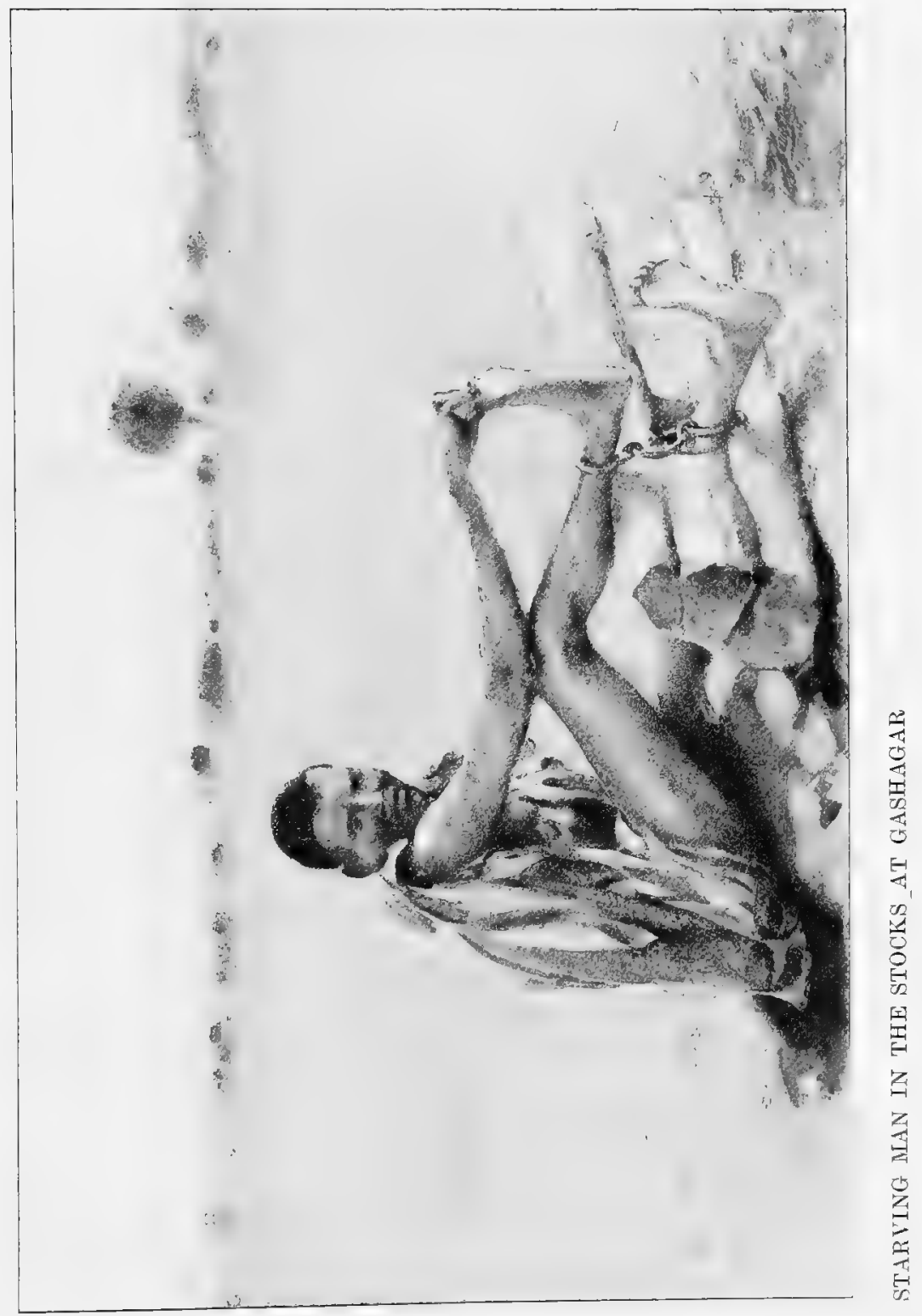



tended at Maifoni owing to Josés falling ill with dysentery. Besides these delays, a few more days were lost in going off the road to have a brush with the Tubus, but I will keep the account of this over till another chapter.

At Gashagar, a Mobbur village, the chief ran away on our approach, for he was suffering from a guilty conscience, as was afterwards revealed. One of my "boys," on going into the bush to cut wood, found a man chained up there in stocks. He had been left starving for ten days and was in a pitiful condition from exhaustion and exposure. His brother soon afterwards came up and explained the unhappy situation. It transpired that the rascally king was trying to extort cattle from the brother who was free as the price of the release of the brother in bondage; but though the free man had cattle and to spare, it did not appear from his manner to us that he had intended making tha s.crifice. José cooked some bovril for the poor released wretch, and when he had recovered a little we put him on a bullock and carried him on to the next village. There were other signs of the King of Gashagar's maladministration, for the village was very deserted, most of the natives having gone over to the French side of the river to escape his extortions. While in the neighbourhood of Yo I saw another case of misrule. The Lowan of Kowa came bearing a spurious order, purporting to be from the Shehu of Kukawa representing the British Government, and with this and by forcing the natives to swear on the Koran that they would come in to him the next day and pay a tax of a dollar per head, he succeeded in collecting for himself the nice little sum of 500 dollars. On hearing of this, I at once sent for the Kachella of Yo and the 
Lowan of Kowa. The latter acknowledged his wrong and gave up the money, which I handed over to the Kachella, telling him to give it to the British Resident. My action, however, was not appreciated by the Resident, but I am pleased to think that my report was instrumental in clearing the Government of extortion in the eyes of the natives, for I afterwards learned from the Lowan himself, that he was heavily fined for his crime by the Resident, and he offered me all the cattle I wanted if I would get him off.

At Gashagar I shot some specimens of the cow-bird, the first I had seen. It is a brown bird with an orange beak, tipped with bright red. It is allied to our starlings, and, like them, feeds off the maggots in the backs of sheep or cattle.

We came upon a caravan of Kanuri at the first well on the road to Maifoni. They had five little ostriches about three weeks old, which they had taken from Tubus. I bought the birds from them for some cloth, but alas! only two lived to reach camp at Kaddai, and they, too, came soon afterwards to a tragic end.

When we arrived at Maifoni, I went to the Assistant Resident and obtained his permission to get the King of Maifoni to send round his people and raise fifty oxen for me. I promised the king a sword, similar to the one I had given the Shehu, on the successful completion of the loan. The king went round his big men in person, and José, who accom. panied him, had cause once or twice to observe transactions that were suspiciously like extortion. However, the drivers came in with their oxen to the number of fifty, and took up their quarters close to the spot where I was camping, near 
the tree that marks my brother's grave. But here, owing to José's illness, we were delayed for two days, at which all the drovers save four got restless and decamped with their oxen in the night. I summoned the king and asked

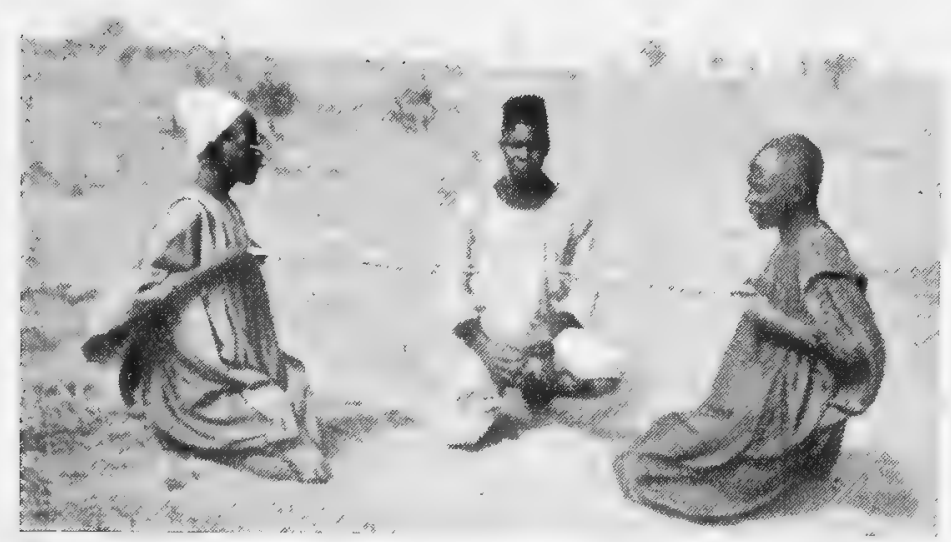

TRIAL BY ORDEAL

him to call his men in again, whereupon he was extremely insolent, telling me to go and fetch them myself. There is only one remedy that meets the case of such insolence from a native to a white man. So, using my privilege of the powers of an Assistant Resident given me by the Colonial Office before leaving England, I ordered him to be flogged, and reported it to the Assistant Resident at Maifoni. Some days later the chief went and complained to the Resident, who fined me $£ 5$. Before leaving Nigeria I reported the matter to the Colonial Office.

While at Maifoni I witnessed an interesting trial by ordeal. One of my "bovs" was suspected by his comrades 
of stealing their cloth, so they summoned two witch doctors to try him. The trial was conducted as follows. The judges knelt opposite each other in front of the "boy," supporting a bamboo cane between their breast bones. They then watched his face and presently the cane, which, of course, was controlled by their breathing, bent slowly towards the culprit, who at once acknowledged the theft. These witch doctors are held in great awe by the natives, and the victim invariably confesses long before their magic begins to work.

I went from Maifoni to Kukawa, and, arriving there opportunely, found our old friend the Shehu, who came to my rescue with a very fine lot of fifty oxen. We went at once with these into Kaddai camp, where we arrived on February 11. The fine appearance of the beasts rejoiced the heart of Gosling, who was beginning to get uneasy at my lengthened absence.

END OF VOL. I 





$(-245$

$40+2 x=5=$

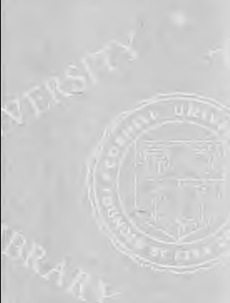

and

$x+\frac{10}{20}$

$96)$<smiles>C1=CCCC=C1</smiles>

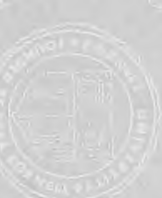

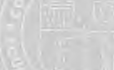

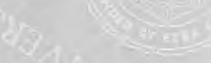

vat

-<smiles>C1CCCCC1</smiles>

(s)

4<smiles>C1CC[Ge]CC1</smiles>

$x^{2}+2$

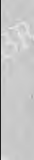

(7)

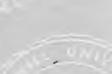

No

8

and.

30

(4)<smiles>C1=C2CCCCCC2CCC1</smiles>

(2)

$4+2 x+2=$

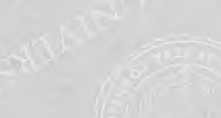

tra<smiles>CCCCCC</smiles><smiles>c1cc2ccc1CC2</smiles>

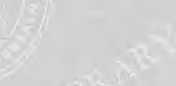


